\title{
Idaho National Engineering Laboratory Site Environmental Report for Calendar Year 1994
}

Environmental Science and Research Foundation

July 1995
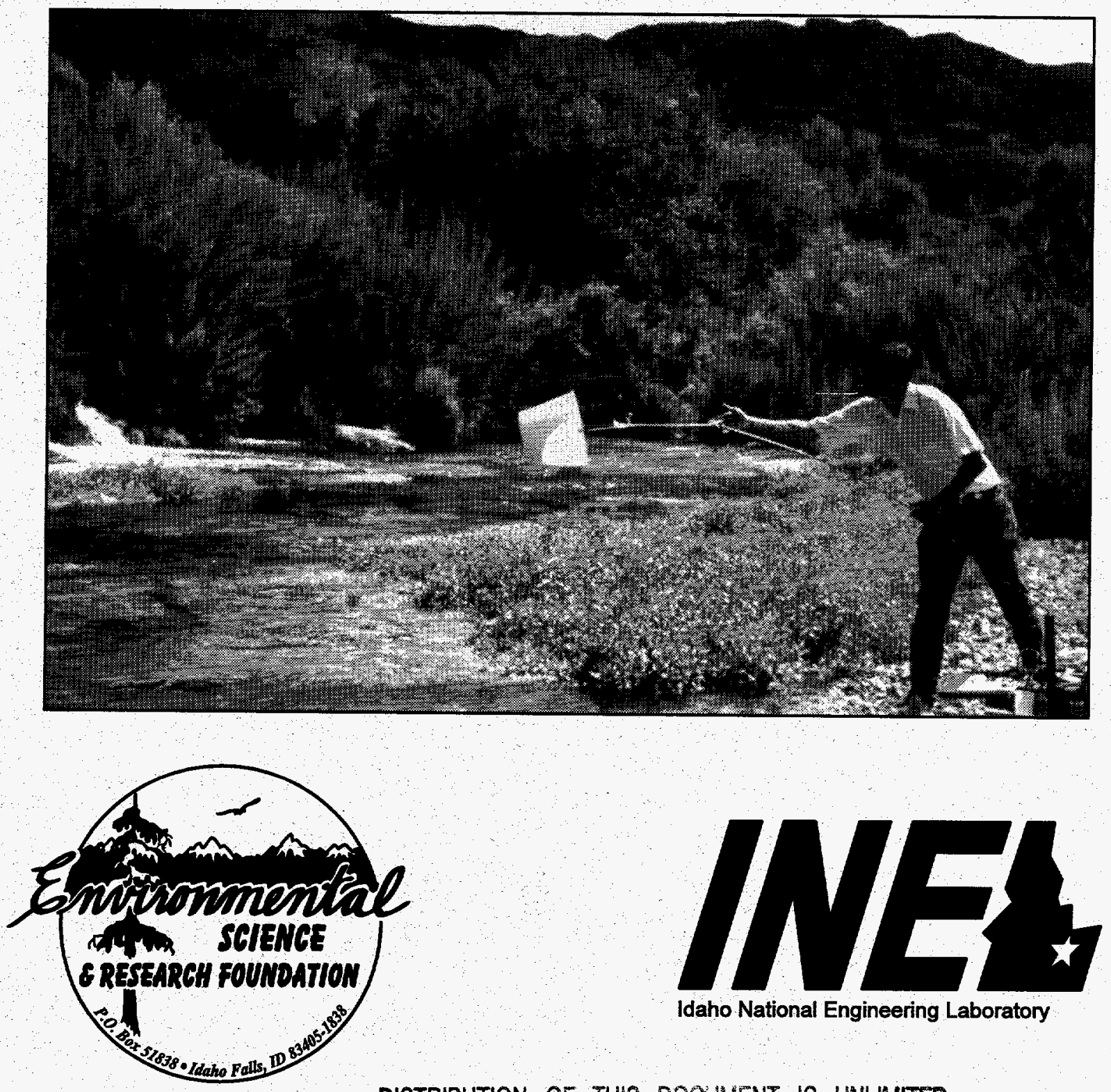

Idaho National Engineering Laboratory

DISTRIBUTION OF THIS DOCUMENT IS UNLMMTED 


\section{DISCLAIMER}

This report was prepared as an account of work sponsored by an agency of the United States Government. Neither the United States Government nor any agency thereof, nor any of their employees, makes any warranty, express or implied, or assumes any legal liability or responsibility for the accuracy, completeness, or usefulness of any information, apparatus, product, or process disclosed, or represents that its use would not infringe privately owned rights. Reference herein to any specific commercial product, process, or service by trade name, trademark, manufacturer, or otherwise does not necessarily constitute or imply its endorsement, recommendation, or favoring by the United States Government or any agency thereof. The views and opinions of authors expressed herein do not necessarily state or reflect those of the United States Government or any agency thereof.
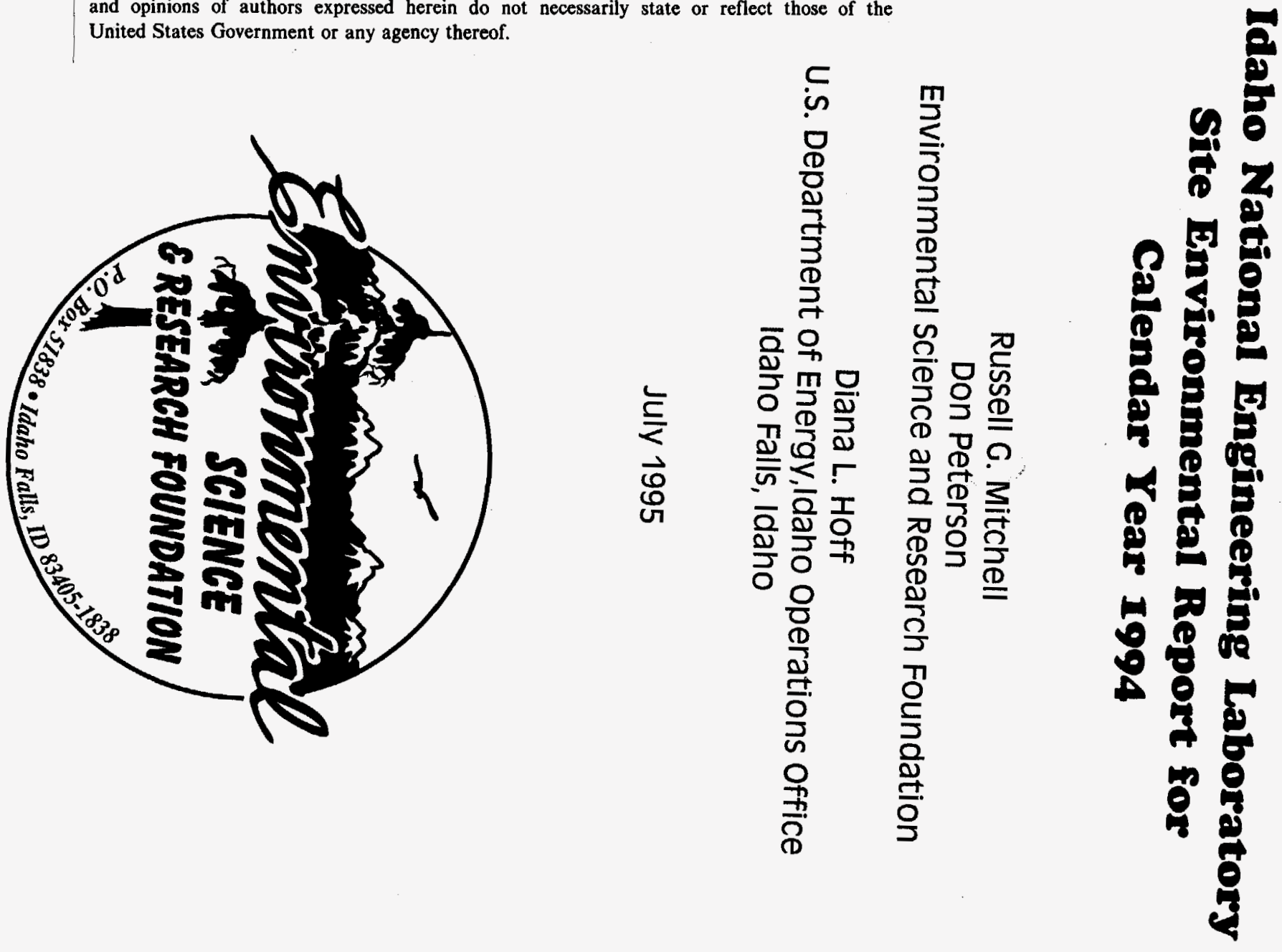



\section{DISCLAIMER}

Portions of this document may be illegible in electronic image products. Images are produced from the best available original document. 


\section{PREFACE}

Every person living in the United States (or the world) is exposed to sources of ionizing radiation--radiant energy that produces ions as it passes through cells. There are three general types of radiation sources: those of natural origin unaffected by human activities, those of natural origin but enhanced by human activities, and those produced by human activities (manmade).

The first group includes terrestrial radiation from natural radiation sources in the ground, cosmic radiation from outer space, and radiation from radionuclides naturally present in the body. Exposures to natural sources may vary depending upon the geographical location and even the altitude at which a person resides. When such exposures are substantially higher than the average, they are considered to be elevated.

The second group includes a variety of natural sources from which the radiation has been increased by human actions. For example, radon exposures in a given home may be elevated because of natural radionuclides in the soil and rock on which the house is built; however, the radon exposures of occupants may be enhanced by characteristics of the home, such as extensive insulation. Another example is the increased exposure to cosmic radiation that airplane passengers receive when traveling at high altitudes.

The third group includes a variety of exposures from manmade materials and devices such as medical $\mathrm{x}$-rays, radiopharmaceuticals used to diagnose and treat disease, and consumer products containing minute quantities of radioactive materials. Exposures may also result from radioactive fallout from nuclear weapons testing, accidents at nuclear power plants, and other such episodic events caused by man's activities in the nuclear industry. Except for major nuclear accidents, such as the one that occurred at Chernobyl, exposures to workers and members of the public from activities at nuclear industries are very small compared to exposures from natural sources ${ }^{a}$.

To verify that exposures resulting from operations at the Department of Energy (DOE) nuclear facilities remain very small, each site at which nuclear activities are underway operates an environmental surveillance program to monitor the air, water and any other pathway whereby radionuclides from operations might conceivably reach workers or members of the public $^{\mathrm{b}}$. Environmental surveillance and monitoring results are reported annually to the DOEHeadquarters.

This report presents a compilation of data collected in 1994 for the routine environmental surveillance programs conducted on and around the Idaho National Engineering Laboratory (INEL). EG\&G conducted the onsite surveillance program from January through September. Lockheed Idaho Technologies Company (LITCO) conducted the onsite program from October through December, subsequent to being awarded the consolidated contract for prime contractor at INEL. During 1994, the offsite surveillance program was conducted by the Environmental Science and Research Foundation. Ground-water monitoring, both on and off site, was performed by the U. S. Geological Survey (USGS). This report also presents summaries of facility effluent monitoring data collected by INEL contractors.

This report, prepared in accordance with the requirements in DOE Order 5400.1, is not intended to cover the numerous special environmental research programs being conducted at the INEL by the Foundation, LITCO, USGS, and others.

\footnotetext{
2 Paraphrased from National Council on Radiation Protection and Measurements, lonizing Radiation Exposure of the Population of the United States, NCRP Report No. 93, September 1, 1987, p. 1.

'DOE Order 5400.1, "General Environmental Protection Program", November 9, 1988.
} 
Section 9.g of DOE 5400.1 exempts the Naval Nuclear Propulsion Program's Naval Reactors Facility (NRF) from the provisions of this order and preparation of the Annual Site Environmental Report since the Naval Nuclear Propulsion Program separately maintains an environmental protection program which assures compliance with all applicable environmental laws and regulations. However, for completeness, the NRF data from onsite surveillance programs are included in this report. In addition, monitoring data and information specific to $\mathrm{NRF}$, similar to that of this report, is provided in a separate annual environmental report issued by NRF.

The Idaho National Engineering Laboratory Site Environmental Report for Calendar Year 1994 was prepared by the Environmental Science and Research Foundation under DOE Contract DE-AC97-94ID13268. 


\section{Helpful Information for the General Reader}

\section{Scientific Notation}

Scientific notation is used to express numbers which are very small or very large. A very small number will be expressed with a negative exponent; e.g., $1.3 \times 10^{-6}$. To convert this number to the more commonly used form, the decimal point must be moved left by a number of places equal to the exponent (in this case 6). The number thus becomes 0.0000013 .

For large numbers, those with a positive exponent, the decimal point is moved to the right by the number of places equal to the exponent. The number $1,000,000$ (or one million) can be written as $1.0 \times 10^{6}$.

\section{Unit Prefixes}

Units for very small or very large numbers are commonly expressed with a prefix. One example is the prefix kilo (abbreviated $\mathrm{k}$ ), which means 1,000 of a given unit. A kilometer is therefore equal to 1,000 meters. Other prefixes used in this report are:

$\begin{array}{cc}\text { Prefix } & \text { Abbreviation } \\ \text { Mega } & \mathrm{M} \\ \text { centi } & \mathrm{c} \\ \text { milli } & \mathrm{m} \\ \text { micro } & \mu \\ \text { nano } & \mathrm{n} \\ \text { pico } & \mathrm{p}\end{array}$

$$
\begin{gathered}
\text { Meaning } \\
1,000,000\left(=1 \times 10^{6}\right) \\
1 / 100\left(=1 \times 10^{-2}\right) \\
1 / 1,000\left(=1 \times 10^{-3}\right) \\
1 / 1,000,000\left(=1 \times 10^{-6}\right) \\
1 / 1,000,000,000\left(=1 \times 10^{-9}\right) \\
1 / 1,000,000,000,000\left(=1 \times 10^{-12}\right)
\end{gathered}
$$

\section{Units of Radioactivity and Radiation Exposure and Dose}

The basic unit of radioactivity used in this report is the curie (abbreviated $\mathrm{Ci}$ ). The curie is based on the radionuclide Radium-226, of which one gram decays at the rate of 37 billion disintegrations per second. For any other radionuclide, one curie is the amount of the radionuclide that decays at this same rate.

Radiation exposure is expressed in terms of the Roentgen (R), the amount of ionization produced by gamma radiation in air. Dose is given in units of "Roentgen equivalent man" or rem, which takes into account the effect of radiation on tissues. For the types of environmental radiation generally encountered, the unit of Roentgen is approximately numerically equal to the unit of rem. 


\section{Units of Environmental Concentrations}

Concentration of radioactivity in air samples and liquid samples such as water and milk is expressed in units of microcuries per milliliter $(\mu \mathrm{Ci} / \mathrm{mL})$ of air or liquid. Radioactivity in foodstuffs is expressed in microcuries per gram $(\mu \mathrm{Ci} / \mathrm{g})$, dry weight. Radioactivity in soil samples is expressed in terms of both the sample dry weight and the ground surface area represented by the sample: picocuries per gram $(\mathrm{pCi} / \mathrm{g})$ and nanocuries per square meter $\left(\mathrm{nCi} / \mathrm{m}^{2}\right)$. Annual human radiation exposure, measured by environmental dosimeters, is expressed in units of milliRoentgens $(\mathrm{mR})$. This is sometimes expressed in terms of dose as millirem (mrem), after being multiplied by an appropriate dose equivalent conversion factor.

\section{Uncertainty of Measurements}

Due to a variety of variables, there is always an uncertainty associated with the measurement of environmental contaminants. For radioactivity, the predominant source of uncertainty is due to the inherent statistical nature of radioactive decay events, particularly at the low activity levels encountered in environmental samples. The uncertainty of a measurement is denoted by following the result with a " \pm " (uncertainty) term. This report follows convention in reporting the uncertainty as a $95 \%$ confidence limit (or interval). That means there is about a 95\% confidence that the real concentration in the sample lies somewhere between the measured (reported) concentration minus the uncertainty term and the measured (reported) concentration plus the uncertainty term.

\section{Negative Numbers as Results}

Environmental measurements are frequently conducted at levels where the contaminant (such as radioactivity) cannot be distinguished from natural background levels. In this case, the result will still be reported, even though it is below the measurement system's detection limit or is less than zero. Negative values occur when the measured result is less than a preestablished average background level for the particular system and procedure used. These values, rather than "not detectable" or "zero," are reported to better enable statistical analyses and observe trends or bias in the data. 


\section{Radionuclide Nomenclature}

Radionuclides are expressed with the one- or two-letter chemical symbol for the element. Radionuclides may have many different isotopes, which are shown by a superscript to the left of the symbol. This number is the atomic weight of the isotope (the number of protons and neutrons in the nucleus of the atom). Radionuclide symbols used in this report are shown in the following table.

\begin{tabular}{|c|c|c|c|}
\hline Radionuclide & $\frac{\text { Symbol }}{3 x}$ & Radionuclide & $\frac{\text { Symbol }}{212 B i}$ \\
\hline Tritium & ${ }^{3} \mathrm{H}$ & Bismuth-212 & \\
\hline Beryllium-7 & ${ }^{7} \mathrm{Be}$ & Lead-214 & ${ }^{214} \mathrm{~Pb}$ \\
\hline Carbon-14 & ${ }^{14} \mathrm{C}$ & Bismuth-214 & ${ }^{214} \mathrm{Bi}$ \\
\hline Sodium-24 & ${ }^{24} \mathrm{Na}$ & Radon-220 & \\
\hline Potassium-40 & ${ }^{40} \mathrm{~K}$ & Radon-222 & \\
\hline Argon-41 & ${ }^{41} \mathrm{Ar}$ & Actinium-228 & ${ }^{228} \mathrm{Ac}$ \\
\hline Chromium-51 & ${ }^{51} \mathrm{Cr}$ & Thorium-232 & ${ }^{232} \mathrm{Th}$ \\
\hline Manganese-54 & ${ }^{54} \mathrm{Mn}$ & Uranium-234 & 234 \\
\hline Iron-55 & ${ }^{55} \mathrm{Fe}$ & Uranium-238 & ${ }^{238} \mathrm{U}$ \\
\hline Cobalt-58 & ${ }^{58} \mathrm{Co}$ & Plutonium-238 & ${ }^{238} \mathrm{~F}$ \\
\hline Cobalt-60 & 要 $\mathrm{Co}$ & Plutonium-239/240 & $239 / 240 \mathrm{~F}$ \\
\hline Zinc-65 & ${ }^{65} \mathrm{Zn}$ & Americium-241 & ${ }^{241} \mathrm{Am}$ \\
\hline Krypton-85 & ${ }^{85} \mathrm{Kr}$ & Curium-242 & ${ }^{242} \mathrm{Cm}$ \\
\hline Krypton-87 & ${ }^{87} \mathrm{Kr}$ & Curium-244 & ${ }^{244} \mathrm{Cm}$ \\
\hline Krypton-88 & ${ }^{88} \mathrm{Kr}$ & & \\
\hline Rubidium-88 & ${ }^{88} \mathrm{Rb}$ & & \\
\hline Rubidium-89 & ${ }^{89} \mathrm{Rb}$ & & \\
\hline Strontium-90 & ${ }^{90} \mathrm{Sr}$ & & \\
\hline Yttritum-90 & ${ }^{90} \mathrm{Y}$ & & \\
\hline Technetium-99 & ${ }^{99} \mathrm{Tc}$ & & \\
\hline Ruthenium-103 & ${ }^{103} \mathrm{Ru}$ & & \\
\hline Ruthenium-106 & ${ }^{106} \mathrm{Ru}$ & & \\
\hline Antimony-125 & ${ }^{125} \mathrm{Sb}$ & & \\
\hline Iodine-129 & ${ }^{129} \mathrm{I}$ & & \\
\hline Iodine-131 & ${ }^{131} \mathbf{I}$ & & \\
\hline Iodine-132 & ${ }^{132} \mathrm{I}$ & & \\
\hline Iodine-133 & ${ }^{133} \mathrm{I}$ & & \\
\hline Xenon-133 & ${ }^{133} \mathrm{Xe}$ & & \\
\hline Xenon-135 & ${ }^{135} \mathrm{Xe}$ & & \\
\hline Cesium-137 & ${ }^{137} \mathrm{Cs}$ & & \\
\hline Cesium-138 & ${ }^{138} \mathrm{Cs}$ & & \\
\hline Barium-139 & ${ }^{139} \mathrm{Ba}$ & & \\
\hline Cesium-140 & ${ }^{140} \mathrm{Cs}$ & & \\
\hline Xenon-140 & ${ }^{140} \mathrm{Xe}$ & & \\
\hline Cerium-144 & ${ }^{144} \mathrm{Ce}$ & & \\
\hline Thallium-208 & ${ }^{208} \mathrm{Tl}$ & & \\
\hline Lead-212 & ${ }^{212} \mathrm{~Pb}$ & & \\
\hline
\end{tabular}




\section{ACRONYMS}

ANI-W

ARA

BAW

CAA

CIRCLA

CFA

CFR

CFSGP

CTF

CWA

DEO

DOI

DO13-II)

DOL-HO

DWR

EBR-I
Argonne National

Laboratory-West

Auxiliary Reactor Area

Babcock \& Wilcox Idaho, Inc.

Clean Air Act

Comprehensive

Environmental Response, Compensation, and Liability Act

Central Facilities Area

Code of Federal Regulations

Coal-Fired Steam Generating Facility

Containment Test Facility

Clean Water Act

(Idaho) Division of

Environmental Quality

U.S. Department of Energy

Department of Energy, Idaho Operations Office

Department of Energy, Headquarters

(Idaho) Department of Water Resources

Experimental Breeder Reactor-I
EBR-II

EFS

EIS

EML

BPA

IPCRA

FRR-EIS

ICPP

INEL

INEL-EIS

INWMIS

ISU

IITCO

MCL
Experimental Breeder

Reactor-II

Experimental Field Station

Environmental Impact

Statement

Environmental

Measurements Laboratory

Environmental Protection

Agency

Emergency Planning and

Community Right-to-Know Act

Foreign Research Reactor Environmental Impact

Statement

Idaho Chemical Processing Plant

Idaho National Engineering Laboratory

Programmatic Spent Fuel Mgt \& Envir. Restoration \& Waste Mgt Env. Impact Statement

INEL Nonradiological Waste Management Information System

Idaho State University

Lockheed Idaho

Technologies Company

Maximum Contaminant

Level 


\section{ACRONYMS (Cont.)}

NCRP

NEPA

NESHAPS

NIST

NOAA/ARI

VPS/

IMPROVE

NRF

PIBF

(QAP

RCRA

RESL
National Council on

Radiation Protection and

Measurements

National Environmental

Policy Act

National Emission Standards

for Hazardous Air Pollutants

National Institute of

Standards and Technology

National Oceanic

and Atmospheric

Administration/Air

Resources Laboratory

National Park

Service/Interagency

Monitoring of Protected

Visual Environments

National Pollution Discharge

Elimination System

Naval Reactors Facility

Power Burst Facility

Quality Assessment Program

Resource Conservation and

Recovery Act

Radiological and

Environmental Sciences

Laboratory
RI/RS

RMI

RWMC

RWMIS

SARA

SDWA

SWPPP

TAN

TID

TRA

TSF

USGS

VANB

WEC
Remedial Investigation/

Feasibility Study

Radiological

Measurements

Laboratory

Radioactive Waste

Management Complex

Radioactive Waste

Management

Information System

Superfund Amendment and Reauthorization

Act

Safe Drinking Water Act

Storm Water Pollution Prevention Plan

Test Area North

Thermoluminescent

Dosimeter

Test Reactor Area

Technical Services

Facility

U.S. Geological Survey

Van Buren Avenue

Westinghouse Electric

Corporation 


\section{ACRONYMS (Cont.)}

WINCO

WIAP

WRR'TF
Westinghouse Idaho Nuclear

Company

Wastewater Land Application

Permit

Water Reactor Research Test

Facility 


\section{EXECUTIVE SUMMARY OF THE ENVIRONMENTAL SURVEILLANCE PROGRAM}

The results of the various monitoring programs for 1994 indicated that most radioactivity from the Idaho National Engineering Laboratory (INEL) operations could not be distinguished from worldwide fallout and natural radioactivity in the region surrounding the INEL Site. Although some radioactive materials were discharged during Site operations, concentrations and doses to the surrounding population were of no health consequence and were far less than State of Idaho and Federal health protection guidelines. Chapter 2 of the report summarizes INEL activities related to compliance with environmental regulations and laws for Calendar Year 1994.

During 1994, a year of management transition at INEL, Lockheed Idaho Technologies Company (LITCO) was awarded the consolidated contract as managing and operating contractor for the INEL. With this change came changes in the management of the onsite surveillance program. From January through September, subsequent to the Department of Energy's 1993 decision to remove themselves from direct performance of environmental surveillance activities, EG\&G conducted the onsite surveillance program. LITCO assumed this responsibility on October 1 after receiving the consolidated contract award. Text and tables in this report refer jointly to these programs, for 1994, as EG\&G/LITCO. The Environmental Science and Research Foundation, a non-profit organization,, took over responsibility for the offsite surveillance program from the Department of Energy's Radiological and Environmental Sciences Laboratory during April 1994.

The major portion of this report summarizes results of the environmental surveillance programs conducted by EG\&G/LITCO, and the Environmental Science and Research Foundation. This includes the collection of foodstuffs at the INEL boundary and distant offsite locations, and the collection of air and water samples at onsite locations and offsite boundary and distant locations. The report also compares and evaluates the sample results to appropriate federal regulations and standards and discusses implications, if any. The U.S. Geological Survey (USGS) ground-water monitoring program is briefly summarized and data from USGS reports are included in maps showing the spread of contaminants. Effluent monitoring and nonradiological drinking water monitoring performed by INEL contractors are discussed briefly and data are summarized in tables.

Gross beta measurements, which are used as a screening technique for air sampler filters, were investigated by making statistical comparisons between onsite or boundary location concentrations and the distant community group concentrations. Statistical differences were noted in about $10 \%$ of the offsite comparions and $18 \%$ of the onsite comparisons. At least some of the statistical differences appeared to be a result of INEL operations but these could not be correlated to any specific facility release.

Air samples were also analyzed for specific radionuclides. Some radionuclides were detected at offsite locations, but most were near the minimum detectable concentration and their presence was attributable to natural sources, worldwide fallout, or statistical variations in the analyses rather than to Site operations. The presence of ${ }^{90} \mathrm{Sr}$ may have been attributable to INEL operations or may be a result of worldwide fallout. Plutonium-238 at one location was attributed to resuspension of soil particles by construction activities. The annual concentrations of all specific nuclides detected at all locations were well below the DOE's derived concentration guides for radiation protection. ${ }^{c}$

Tritium was not detected in any atmospheric moisture or precipitation samples, onsite or offsite.

'Derived concentration guides (DCG) are contained in DOE Order 5400.5 . 
Approximately $12 \%$ of all drinking water samples collected during 1994 contained detectable concentrations of gross alpha activity; about $19 \%$ contained detectable gross beta activity. All concentrations of both types of activity were near the minimum detectable concentration and were probably due to natural radioactivity or to statistical variation in the analyses. Annual averages for all onsite and offsite drinking water samples were below the maximum contaminant level established by the Environmental Protection Agency (EPA) for public drinking water systems.

No offsite water samples contained detectable tritium concentrations. Five onsite production (drinking water) wells contained measurable concentrations of tritium. An effective dose equivalent of $0.7 \mathrm{mrem} / \mathrm{yr}$ was estimated for INEL workers at the Central Facilities Area, the location with the highest tritium concentration in drinking water. One production well (not used for drinking water), in the vicinity of ICPP, contained detectable levels of ${ }^{90} \mathrm{Sr}$. The levels are consistent with those historically seen. An ICPP drinking water well showed one sample with a slightly detectable level of ${ }^{90} \mathrm{Sr}$, well within the EPA's maximum contaminant level for ${ }^{90} \mathrm{Sr}$.

Concentrations of volatile organic compounds measured in production wells at Test Area North (TAN) that were slightly above the EPA maximum contaminant levels in 1987, have generally been in compliance through 1994 after ap-propriate remedial action was taken. During one month (August) the distribution system at TAN exceeded the maximum contaminant level for trichloroethylene. This was because an aerating system used to volatize the trichloroethylene was not operating properly during that time. Even though the concentration of trichloroethylene was above the maximum contaminant level established for it, the water system was not in service during this period due to detection of coliform bacteria that occurred during July through December. Personnel at TAN were provided with bottled water for drinking purposes.
None of the milk samples contained detectable concentrations of ${ }^{131} \mathrm{I}$ or tritium. Two samples contained concentrations of ${ }^{90} \mathrm{Sr}$ that were consistent with levels seen in samples nationwide, as reported by the EPA. Some food samples (lettuce, wheat, potatoes) contained small amounts of ${ }^{90} \mathrm{Sr}$. The presence of ${ }^{90} \mathrm{Sr}$ in food samples is probably due to its deposition on soil as a result of worldwide fallout. Low concentrations of ${ }^{137} \mathrm{Cs}$ were found in muscle tissue of one pronghorn antelope. The levels were consistent with the concentrations from game animals both onsite and offsite in recent years.

Ionizing radiation measured simultaneously at the Site boundary and distant locations showed only natural background levels.

For details on monitoring results, see the appropriate sections that summarize results of radioactive, nonradioactive, and ground-water monitoring and surveillance programs.

A measurable amount of radioactivity, primarily in the form of noble gases and tritium, is released into the atmosphere annually from various plant facilities and is subsequently carried offsite. Upon reaching the Site boundary, this radioactivity is in such a low concentration that its effect on direct radiation levels cannot be measured; but its potential contribution to offsite dose equivalents is nevertheless calculated.

The hypothetical maximum individual effective dose equivalent was found to occur near Mud Lake and was calculated to be 0.007 mrem ( $7 \times 10^{-5} \mathrm{mSv}$ ) using the MESODIF air dispersion model. The calculation considered continuous submersion in and inhalation of radioactivity in air, ingestion of radioactivity in leafy vegetables, and exposure to radioactive particulates deposited on the ground surface at that location. This calculated effective dose equivalent is about $0.002 \%$ of the natural background radiation effective dose equivalent of approximately 350 mrem per year in this area. The 1994 effective dose equivalent to the maximally exposed individual (who was assumed to live at all offsite receptor points simultaneously), 
calculated using the CAP-88 computer code that is required to demonstrate compliance with EPA regulations, was 0.004 mrem $(0.001 \%$ of background). (See the section entitled "Maximum Individual Dose--Airborne Emissions Pathway" for a complete discussion of the two different computer models used). The maximum calculated dose to an individual by either of the methods is clearly in compliance with the applicable radiation protection standards.

The maximum potential population dose from submersion, ingestion, inhalation, and deposition to the approximately 121,000 people residing within an $80-\mathrm{km}(50-\mathrm{mi})$ radius from the geographical center between the Test Reactor Area and the Idaho Chemical Processing Plant facilities of the INEL Site was estimated to be 0.06 personrem $\left(6 \times 10^{-4}\right.$ person-Sv) using the MESODIF air dispersion model. This population dose is less than $0.001 \%$ of the estimated 42,500 person-rem (425 person-Sv) population dose from natural background radioactivity. These calculations and their implications are discussed in the section "Evaluation of Potential Dose to the Public."

The State of Idaho Oversight Program conducted its independent program of collecting and analyzing air, water, and milk samples at selected locations matching some of the EG\&G/LITCO and Foundation environmental surveillance program locations. Comparisons of EG\&G/LITCO, Foundation, and State data indicate results were of similar magnitude between the three programs, with expected variations resulting when three organizations maintain different sampling and analysis schedules and use different analytical laboratories. 


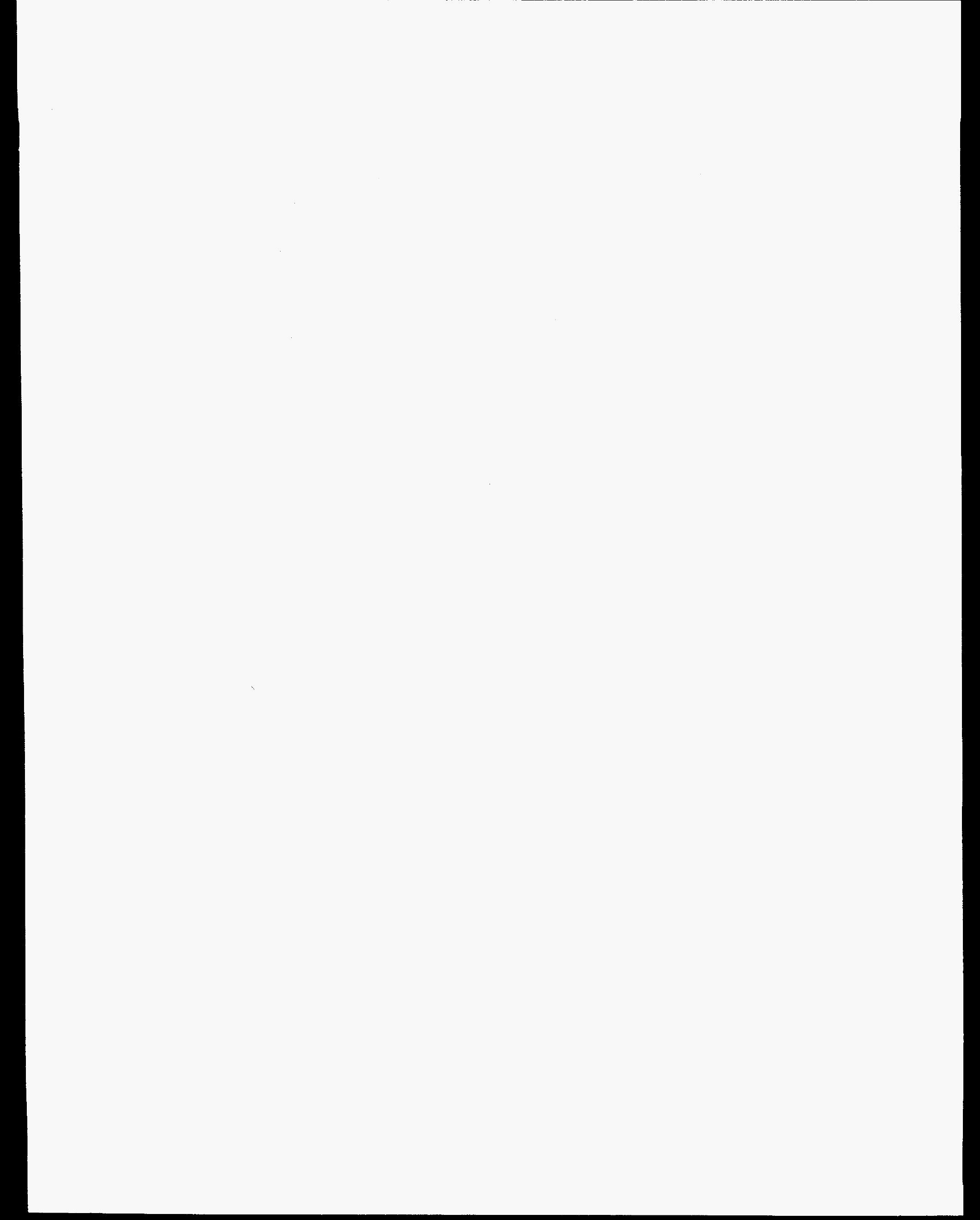




\section{CONTENTS}

Preface

Helpful Information for the General Reader $\ldots \ldots \ldots \ldots \ldots \ldots \ldots \ldots \ldots \ldots \ldots \ldots \ldots \ldots$

Executive Summary of the Environmental Surveillance Program $\ldots \ldots \ldots \ldots \ldots \ldots \ldots$

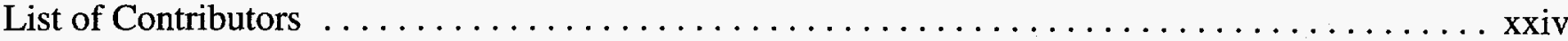

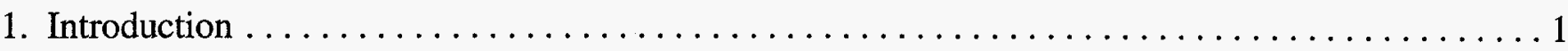

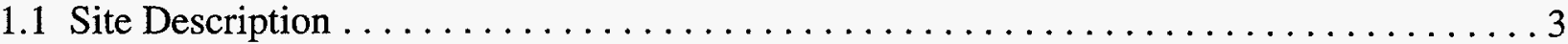

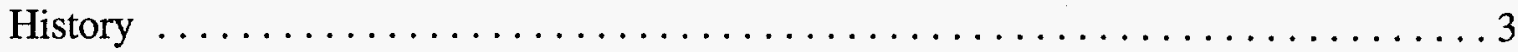

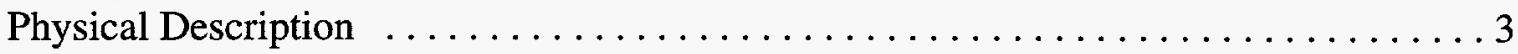

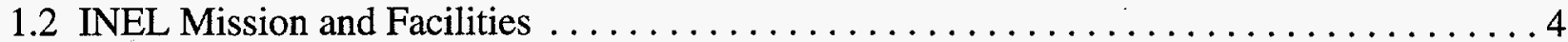

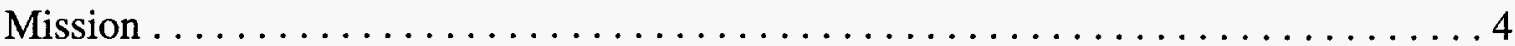

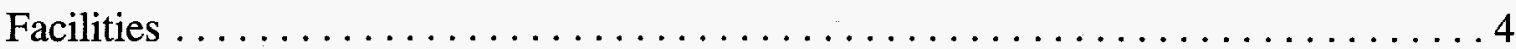

2. Environmental Compliance Summary $\ldots \ldots \ldots \ldots \ldots \ldots \ldots \ldots \ldots \ldots \ldots \ldots$

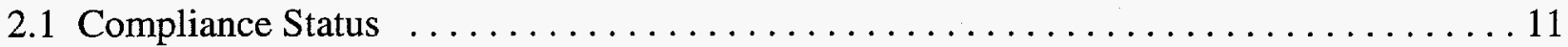

Comprehensive Environmental Response, Compensation and Liability Act $\ldots \ldots \ldots 11$

Emergency Planning and Community Right-to-Know Act $\ldots \ldots \ldots \ldots \ldots \ldots \ldots 11$

Natural Resource Trusteeship \& Natural Resources Damage Assessment . . . . . . . 12

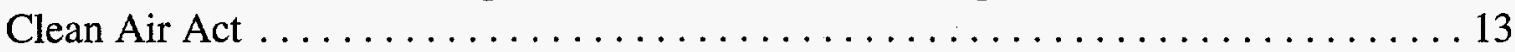

National Emission Standards for Hazardous Air Pollutants . . . . . . . . . . . . . 14

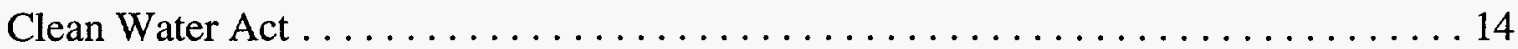

National Pollutant Discharge Elimination System Point Source

Discharge Permits . . . . . . . . . . . . . . . . . . 15

Executive Order 11990--Protection of Wetlands . . . . . . . . . . . . . . . . . . 16

Executive Order 11988--Floodplain Management $\ldots \ldots \ldots \ldots \ldots \ldots \ldots \ldots \ldots$

State of Idaho Wastewater Land Application Permits . . . . . . . . . . . . 17

Resource Conservation and Recovery Act . . . . . . . . . . . . . . . 18

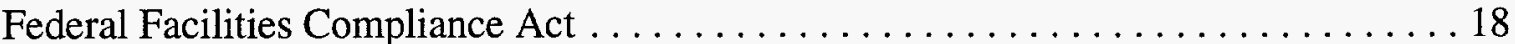

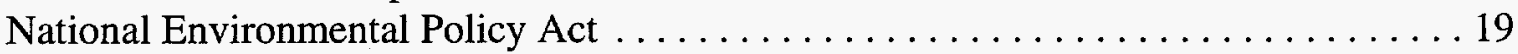

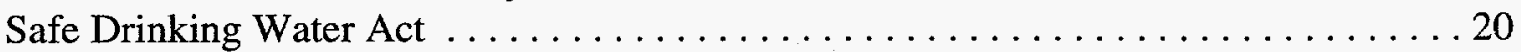

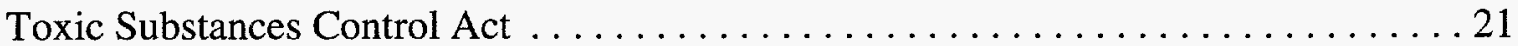

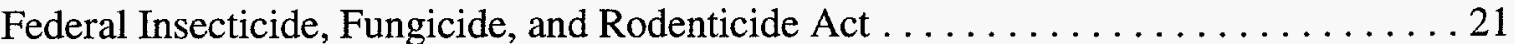

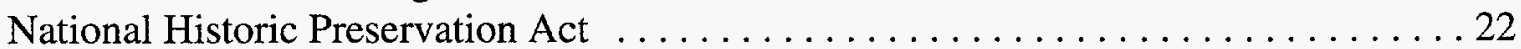

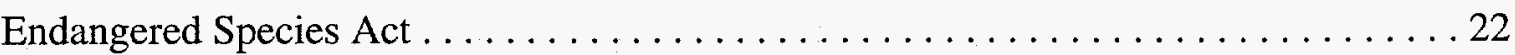




\section{CONTENTS (Cont.)}

2.2 Other Major Environmental Issues and Activities $\ldots \ldots \ldots \ldots \ldots \ldots \ldots \ldots \ldots$

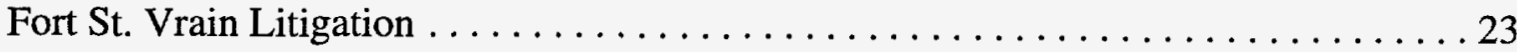

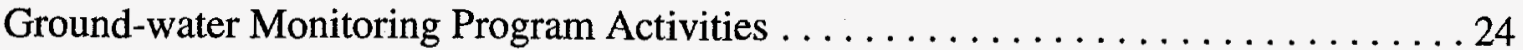

Health Studies . . . . . . . . . . . . . . . . . . . . . . . . . . . . . 24

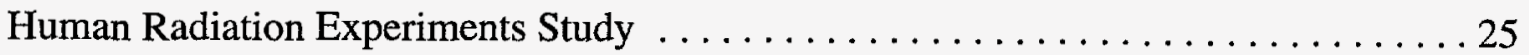

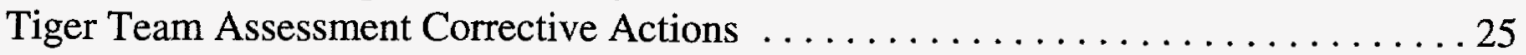

Environmental Occurrences . . . . . . . . . . . . . . . . . . . . 26

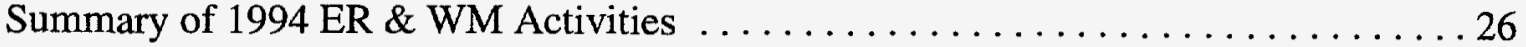

Environmental Oversight and Monitoring Agreement $\ldots \ldots \ldots \ldots \ldots \ldots \ldots \ldots$

The Environmental Management Site Specific Advisory Board--Idaho National

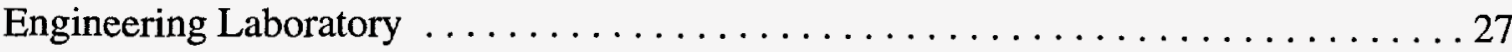

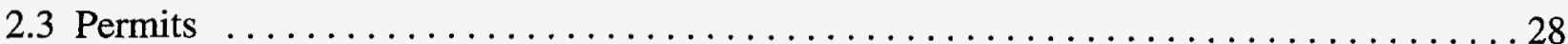

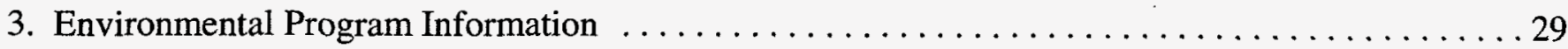

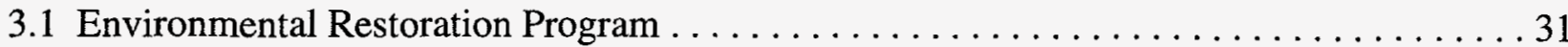

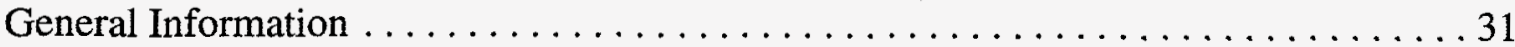

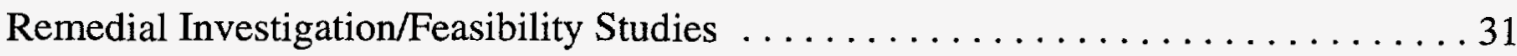

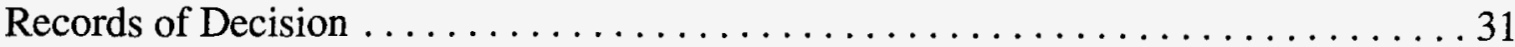

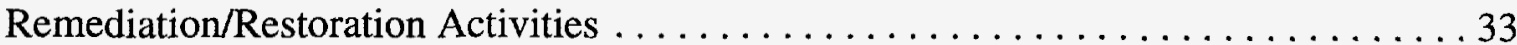

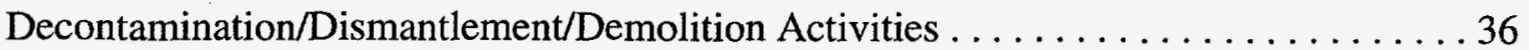

Public Involvement in Environmental Restoration Program Activities . . . . . . . . . 38

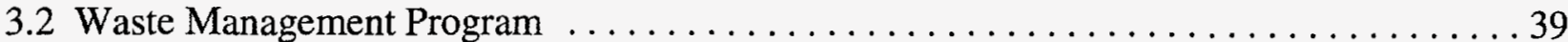

General Information . . . . . . . . . . . . . . . . . . . . . . . . . . . . 39

Waste Management Program Accomplishments for $1994 \ldots \ldots \ldots \ldots \ldots \ldots$. . . . . 39

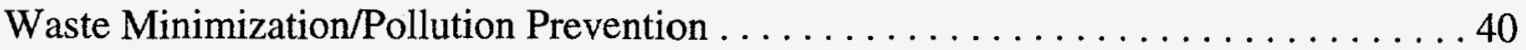

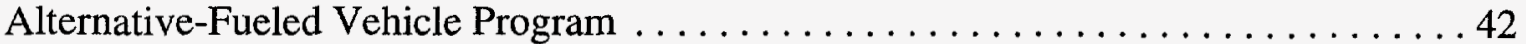

Waste Isolation Pilot Plant Support . . . . . . . . . . . . . . . . . . 42

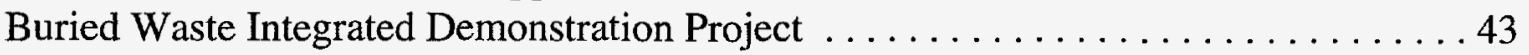

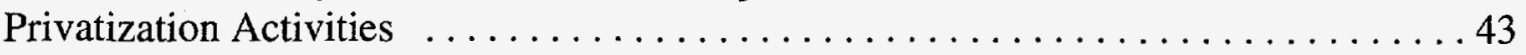

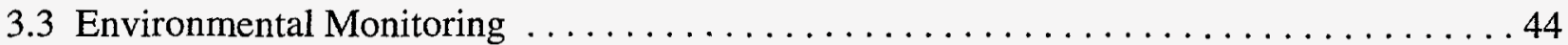

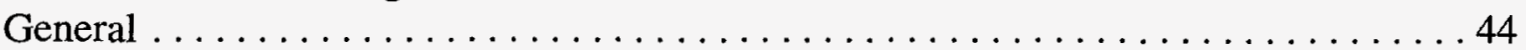

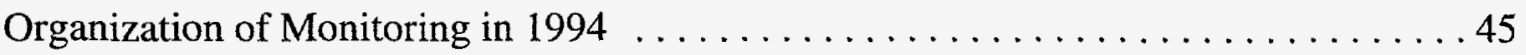

4. Environmental Radiological Program Information $\ldots \ldots \ldots \ldots \ldots \ldots \ldots \ldots \ldots \ldots \ldots \ldots \ldots \ldots$

4.1 Environmental Surveillance Program Description $\ldots \ldots \ldots \ldots \ldots \ldots \ldots \ldots \ldots$

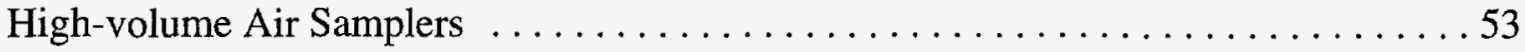

Low-volume Air Samplers . . . . . . . . . . . . . . . . . . . . . . 53 


\section{CONTENTS (Cont.)}

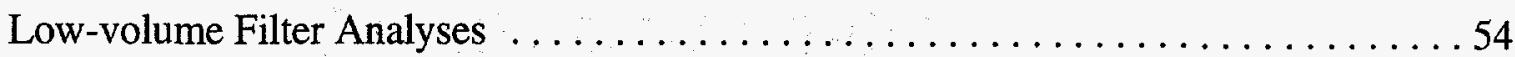

Specific Radionuclide Analyses . . . . . . . . . . . . . . . . . . . . . . . 55

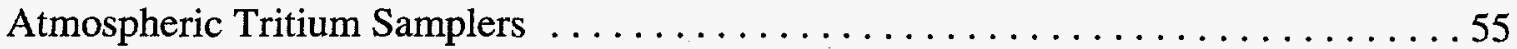

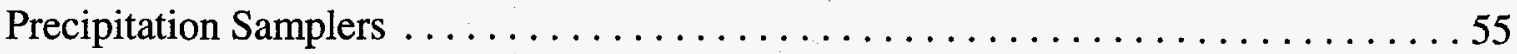

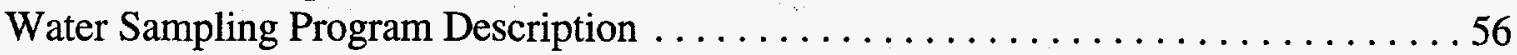

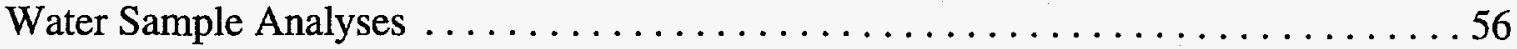

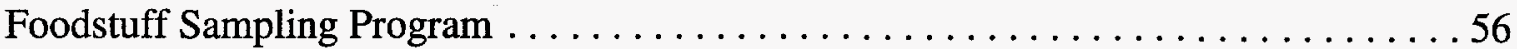

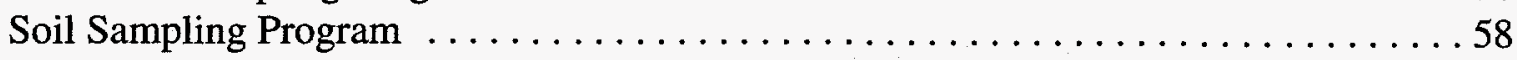

Environmental Dosimeters ................................. 59

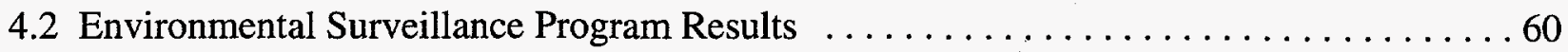

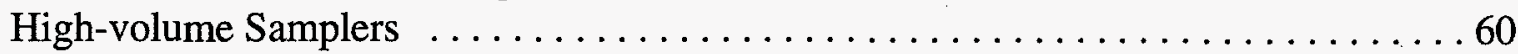

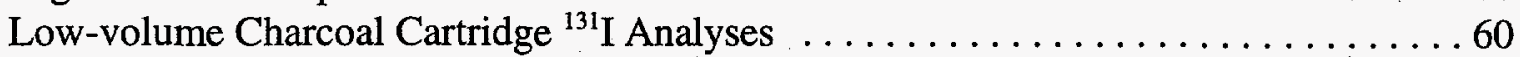

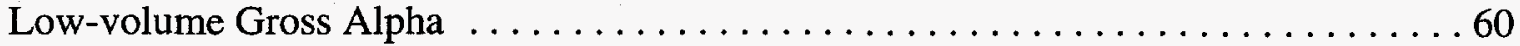

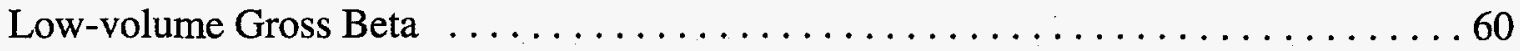

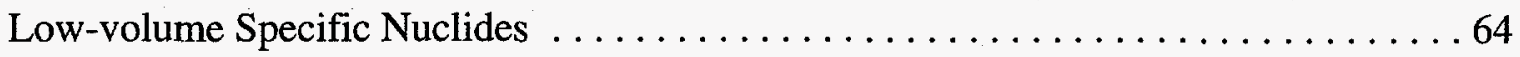

Atmospheric Tritium ......................................... 64

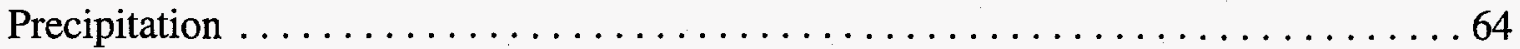

Water Sampling Results . . . . . . . . . . . . . . . . . . . . . . . . . . 69

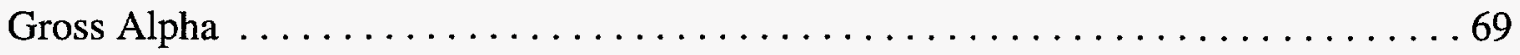

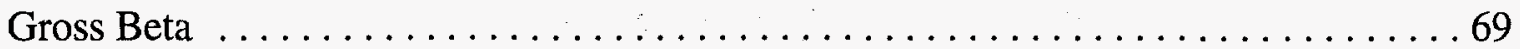

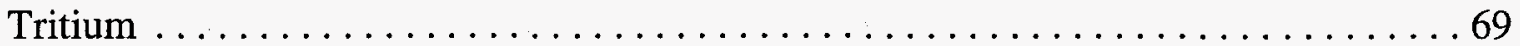

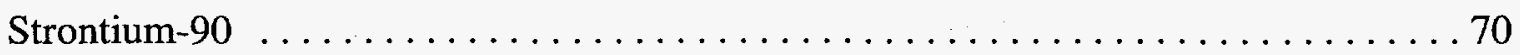

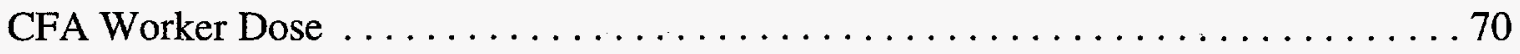

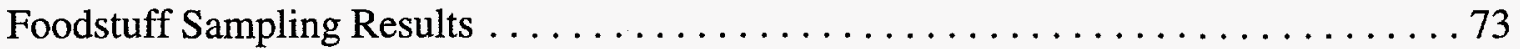

Soil ........................................... 73

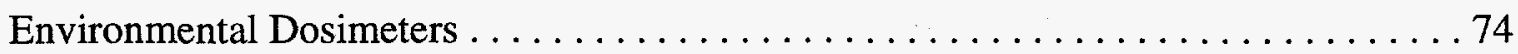

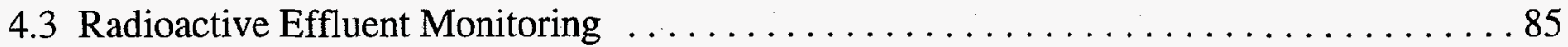

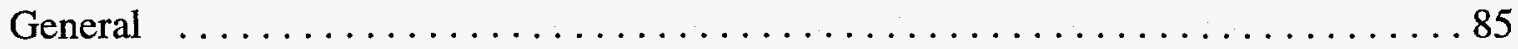

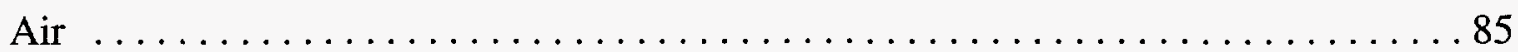

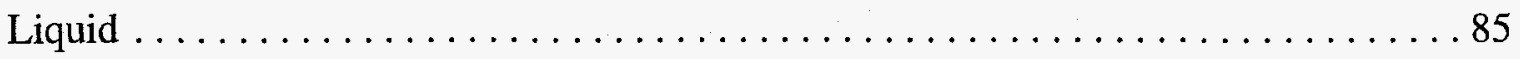

4.4 Evaluation of Potential Radiation Dose to the Public $\ldots \ldots \ldots \ldots \ldots \ldots \ldots \ldots$

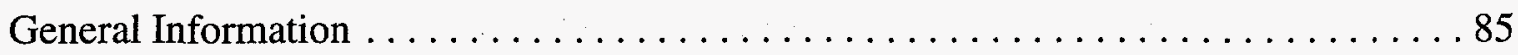

Maximum Individual Dose--Airborne Emissions Pathway $\ldots \ldots \ldots \ldots \ldots \ldots . \ldots 8$

Maximum Individual Dose--Game Ingestion Pathway . . . . . . . . . . . . . 92

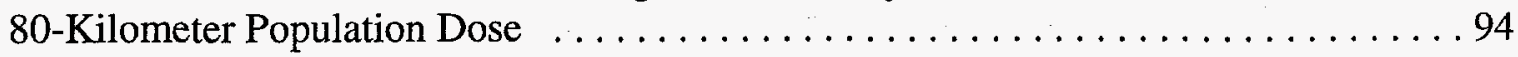

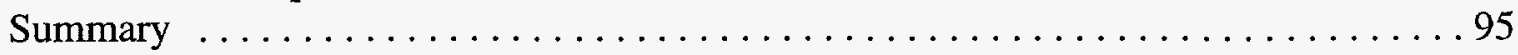

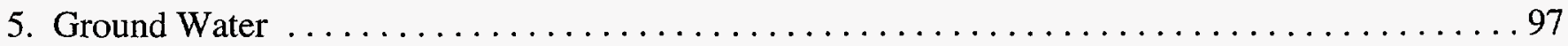




\section{CONTENTS (Cont.)}

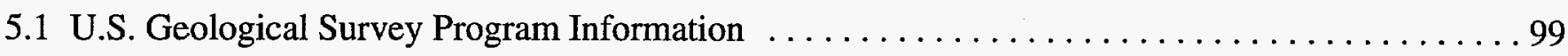

U.S. Geological Survey Program Description ......................... 99

USGS Special Studies .................................. 104

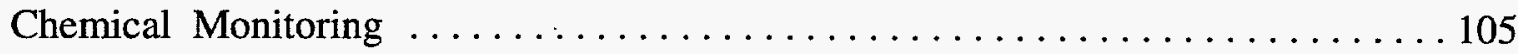

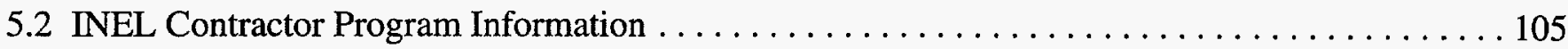

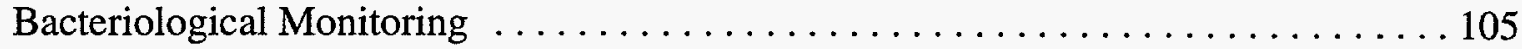

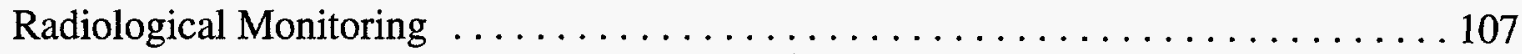

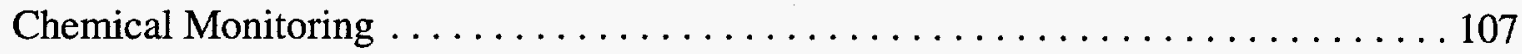

6. Environmental Nonradiological Program Information $\ldots \ldots \ldots \ldots \ldots \ldots \ldots \ldots \ldots \ldots \ldots \ldots \ldots$

6.1 Environmental Surveillance Program Description $\ldots \ldots \ldots \ldots \ldots \ldots \ldots \ldots \ldots \ldots \ldots$

Total Suspended Particulates . . . . . . . . . . . . . . . . . . . . . . . . . . 113

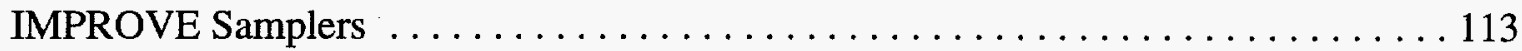

Nitrogen Dioxide/Sulfur Dioxide Monitoring $\ldots \ldots \ldots \ldots \ldots \ldots \ldots \ldots \ldots \ldots$

6.2 Environmental Surveillance Program Results $\ldots \ldots \ldots \ldots \ldots \ldots \ldots \ldots \ldots \ldots . \ldots \ldots$

Total Suspended Particulates . . . . . . . . . . . . . . . . . . . . . . . . . 114

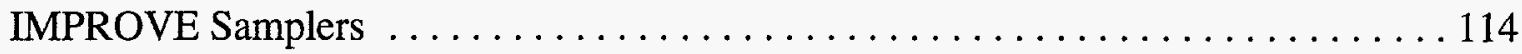

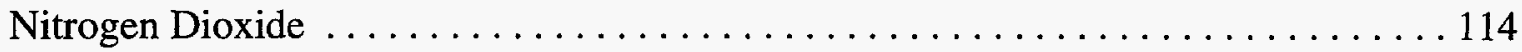

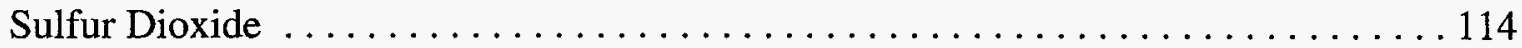

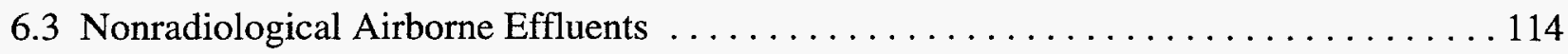

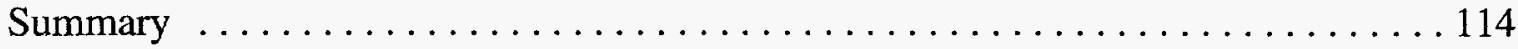

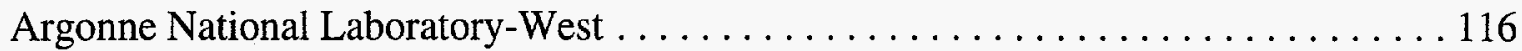

Specific Manufacturing Capability Facility $\ldots \ldots \ldots \ldots \ldots \ldots \ldots \ldots \ldots \ldots \ldots \ldots \ldots$

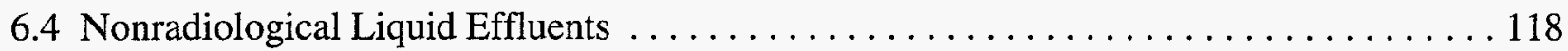

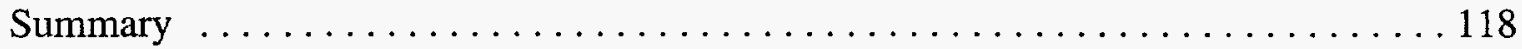

Argonne National Laboratory-West ............................... 119

Specific Manufacturing Capability Facility $\ldots \ldots \ldots \ldots \ldots \ldots \ldots \ldots \ldots \ldots \ldots \ldots$

EG\&G/LITCO . . ..................................... 119

Naval Reactors Facility ..................................... 119

Idaho Chemical Processing Plant ............................. 119

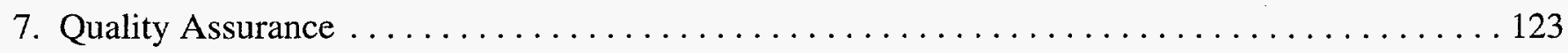

7.1 Quality Assurance Programs . . . . . . . . . . . . . . . . . . . . 125 


\section{CONTENTS (Cont.)}

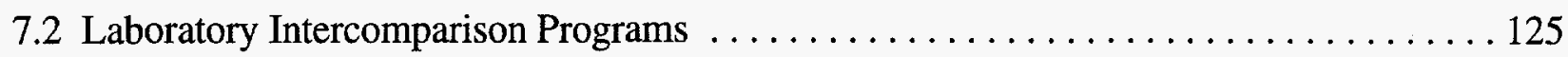

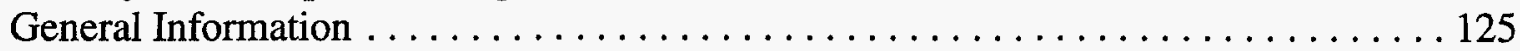

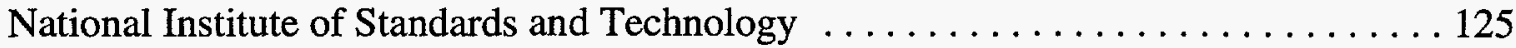

Quality Assessment Program . . . . . . . . . . . . . . . . . . . . . . . 126

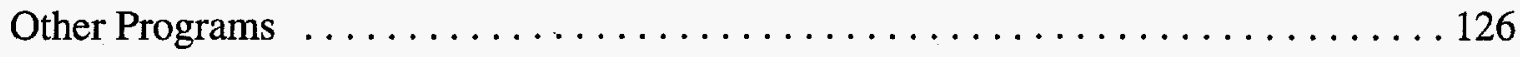

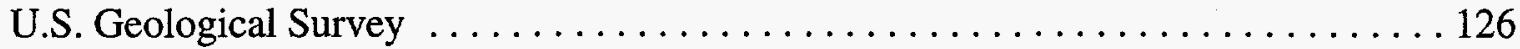

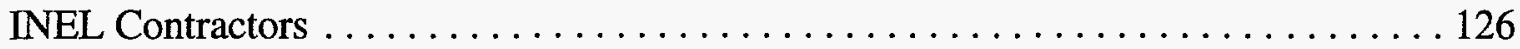

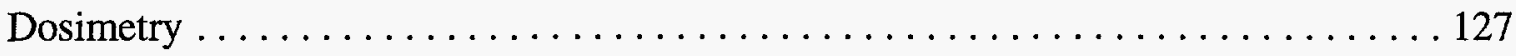

7.3 Data Precision and Verification . . . . . . . . . . . . . . . . . . . . . . 131

Duplicate Sampling . ...................................... 131

Independent Data Comparisons $\ldots \ldots \ldots \ldots \ldots \ldots \ldots \ldots \ldots \ldots \ldots \ldots \ldots \ldots \ldots \ldots \ldots$

Appendix A--Environmental Standards and Regulations $\ldots \ldots \ldots \ldots \ldots \ldots \ldots \ldots \ldots \ldots \ldots \ldots \ldots \ldots$

Appendix B--Statistical Methods Used for the Environmental Surveillance Program . . . . . . . . 141 


\section{FIGURES}

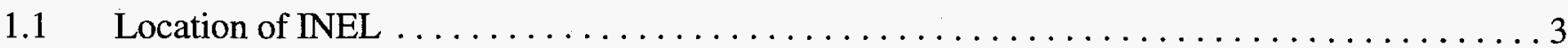

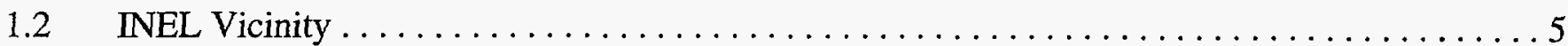

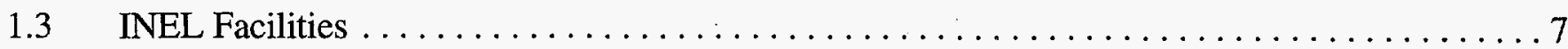

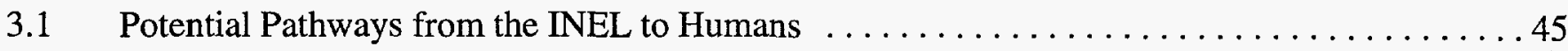

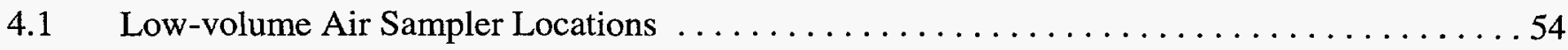

4.2 Water, Foodstuff, and Environmental Dosimeter Sampling Locations . . . . . . . . . . 57

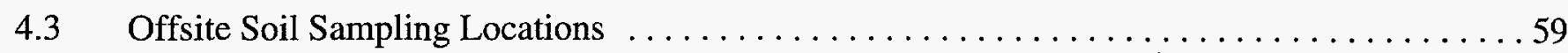

4.4 Weekly Gross Beta Concentrations in Air (1994) ........................ 62

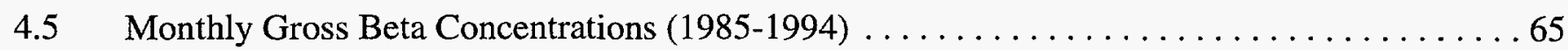

4.6 Water Samples with Detectable Gross Alpha and Gross Beta Concentrations (1994) . . . . . 70

4.7 Tritium Concentrations in INEL Production Wells $(1990-1994) \quad \ldots \ldots \ldots \ldots \ldots \ldots \ldots 72$

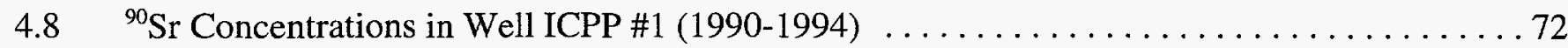

4.9 Environmental Dosimeter Measurements at ANL-W (1994). . . . . . . . . . . . . . . . . 79

4.10 Environmental Dosimeter Measurements at ARA (1994) ........................ 79

4.11 Environmental Dosimeter Measurements at CFA (1994) . . . . . . . . . . . . . . . 80

4.12 Environmental Dosimeter Measurements at ICPP (1994) ..................... 80

4.13 Environmental Dosimeter Measurements at NRF (1994) $\ldots \ldots \ldots \ldots \ldots \ldots \ldots \ldots \ldots \ldots$

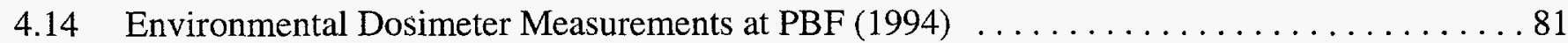

4.15 Environmental Dosimeter Measurements at RWMC (1994). . . . . . . . . . . . . . 82

4.16 Environmental Dosimeter Measurements at TAN (1994) ..................... 82

4.17 Environmental Dosimeter Measurements at TRA (1994). . . . . . . . . . . . . . 83 


\section{FIGURES (Cont.)}

4.18 Environmental Dosimeter Measurements along Lincoln Blvd. and US20 and 26 (1994) . . . 84

4.19 1994 Average of Mesoscale Dispersion Isopleths of Air Concentrations at Ground Level, Normalized to Unit Release Rate . . . . . . . . . . . . . . . . . . . . . . 90

4.20 Radionuclides Contributing to Maximum Individual Dose $(1994) \ldots \ldots \ldots \ldots \ldots 2$

4.21 Radionuclides Contributing to Maximum Individual Dose $(1990-1993) \ldots \ldots \ldots$

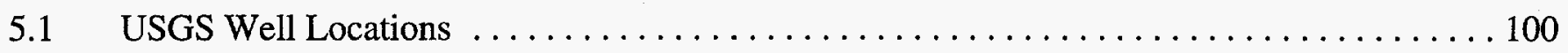

$5.2 \quad$ USGS Well Locations at ICPP-TRA and RWMC $\ldots \ldots \ldots \ldots \ldots \ldots \ldots \ldots \ldots \ldots \ldots \ldots \ldots$

5.3 Distribution of Tritium in the Snake River Plain Aquifer on the INEL, $1991 \ldots \ldots \ldots$. . . . 102

5.4 Distribution of ${ }^{90} \mathrm{Sr}$ in the Snake River Plain Aquifer on the INEL, $1991 \ldots \ldots \ldots \ldots \ldots$ 


\section{TABLES}

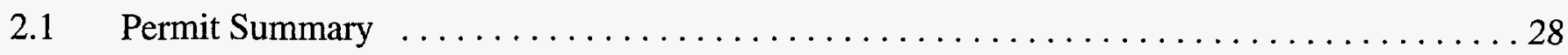

3.1 EG\&G/LITCO Environmental Surveillance Radiological Program Summary (1994) $\ldots \ldots .47$

3.2 Foundation Environmental Surveillance Radiological Monitoring Program Summary (1994) . 48

3.3 USGS Ground-Water Monitoring Program Summary $\ldots \ldots \ldots \ldots \ldots \ldots \ldots \ldots$

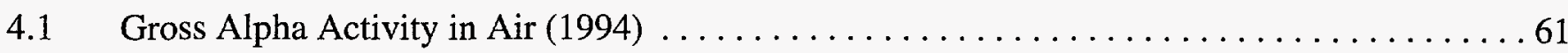

4.2 Gross Beta Statistical Comparison Table (1994) $\ldots \ldots \ldots \ldots \ldots \ldots \ldots \ldots \ldots \ldots \ldots \ldots \ldots \ldots \ldots \ldots$

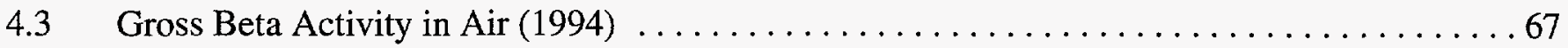

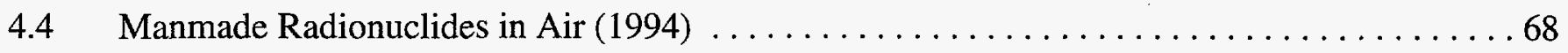

4.5 Tritium Concentrations in INEL Production Wells (1994) $\ldots \ldots \ldots \ldots \ldots \ldots \ldots \ldots \ldots \ldots$

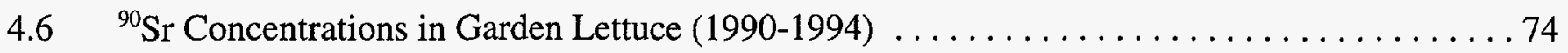

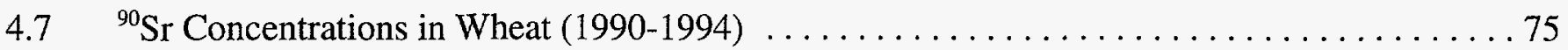

4.8 Radionuclides in Offsite Surface $(0-5 \mathrm{~cm}$. Depth) Soil $(1970-1994) \ldots \ldots \ldots \ldots \ldots \ldots$

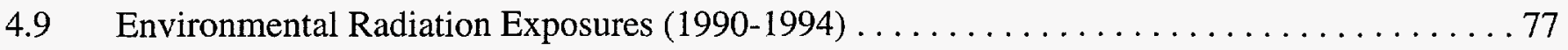

4.10 Estimated Natural Background Effective Dose Equivalent (1994) ................ 78

4.11 Radionuclide Composition of Airborne Effluents (1994) .................... 86

4.12 Radionuclide Composition of Liquid Effluent Released Onsite (1994) . . . . . . . . . . 87

4.13 Maximum Individual Effective Dose Equivalent $(1994) \ldots \ldots \ldots \ldots \ldots \ldots \ldots \ldots \ldots$

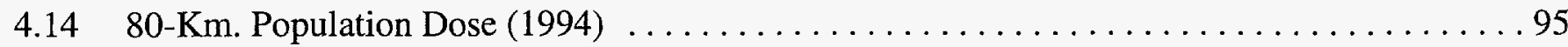

4.15 Smmary of Annual Effective Dose Equivalents Due to INEL Operations (1994) . . . . . . 96

$5.1 \quad$ Purgeable Organic Compounds in USGS Well Samples (1994) . . . . . . . . . . . . . . 106

5.2 Regulated Organic Compounds $[\mu \mathrm{g} / \mathrm{L}]$ in INEL Drinking Water (1994) . . . . . . . . . . 109 


\section{TABLES (Cont.)}

5.3 Inorganic Chemicals in ICPP Potable and Production Wells (1994) . . . . . . . . . . . . 110

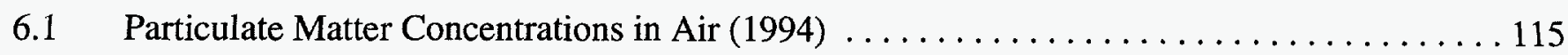

6.2 Ten-Year Summary of Particulate Matter Concentrations (1985-1994) $\ldots \ldots \ldots \ldots \ldots \ldots$

6.3 Data for IMPROVE Samplers at CFA and Craters of the Moon National Monument (June 1992-May 1994) ...................................... 117

6.4 Summary of $\mathrm{NO}_{2}$ and $\mathrm{SO}_{2}$ Emissions and Ambient Monitoring Results (1990-1994) $\ldots \ldots 118$

6.5 TRA Liquid Effluent Inorganic Monitoring Data (1994) $\ldots \ldots \ldots \ldots \ldots \ldots \ldots \ldots \ldots \ldots \ldots$

6.6 NRF Sewage Lagoon Waste Stream Analyses (1994) $\ldots \ldots \ldots \ldots \ldots \ldots \ldots \ldots \ldots \ldots \ldots \ldots \ldots$

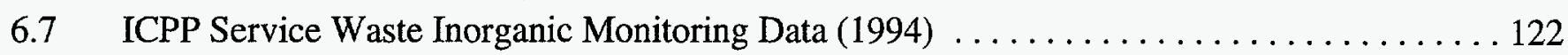

7.1 DOE Environmental Measurements Laboratory Quality Assurance Program Results Comparison For Radiological and Environmental Sciences Laboratory (1994) . . . . . . . . 127

7.2 DOE Environmental Measurements Laboratory Quality Assurance Program Results Comparison For Radiological Measurements Laboratory (1994) . . . . . . . . . . . . . 129

7.3 DOE Environmental Measurements Laboratory Quality Assurance Program Results

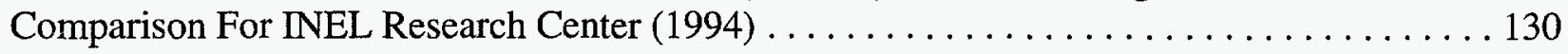

7.4 Comparison of Foundation Duplicate Air Monitoring Results (April - December 1994) . . . 132

7.5 Comparison of EG\&G/LITCO Duplicate Air Monitoring Results (July - December 1994) . . 133

7.6 Comparison of Foundation, EG\&G/LITCO and State of Idaho Air Monitoring Results (1994)--Gross Alpha . . . . . . . . . . . . . . . . . . . . . . . . . . . . . . 134

7.7 Comparison of Foundation, EG\&G/LITCO and State of Idaho Air Monitoring Results (1994)--Gross Beta . . . . . . . . . . . . . . . . . . . . . . . . . . . 135

7.8 Comparison of Foundation and State of Idaho Water Monitoring Results (1994) . . . . . 136

I Derived Concentration Guides for Radiation Protection $\ldots \ldots \ldots \ldots \ldots \ldots \ldots \ldots \ldots$

II Radiation Standards for Protection of the Public in the Vicinity of DOE Facilities . . . . . 139

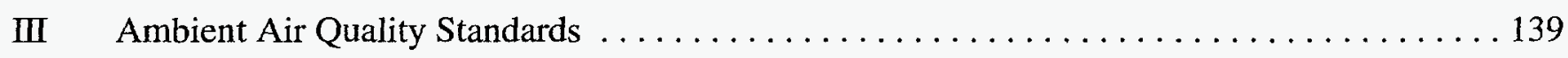

IV Maximum Contaminant Levels for Nontransient Noncommunity Drinking Water Systems .. 140 


\section{LIST OF REPORT CONTRIBUTORS}

The following people contributed data and/or writing to this report:

EG\&G/LITCO Monitoring Information $\ldots \ldots \ldots \ldots \ldots$ Kelly Wright, Bryan Borsella

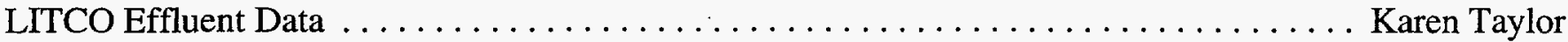

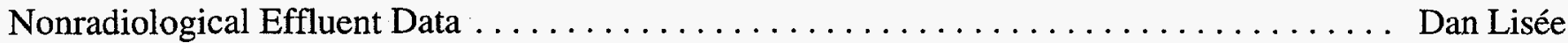
Meteorological Information $\ldots \ldots \ldots \ldots \ldots \ldots \ldots \ldots \ldots \ldots \ldots \ldots \ldots$ Jerrold Sagendorf NESHAPs/CAP $88 \ldots \ldots \ldots \ldots \ldots \ldots \ldots \ldots \ldots \ldots \ldots \ldots \ldots \ldots \ldots \ldots \ldots$ Paul Ritter

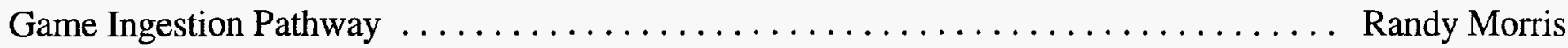
USGS Program Information $\ldots \ldots \ldots \ldots \ldots \ldots \ldots \ldots \ldots \ldots \ldots \ldots \ldots \ldots \ldots \ldots \ldots$ Brennon Orr USGS Purgeable Organic Data $\ldots \ldots \ldots \ldots \ldots \ldots \ldots \ldots \ldots \ldots \ldots \ldots$ Betty Tucker ANL-W Monitoring Data $\ldots \ldots \ldots \ldots \ldots \ldots \ldots \ldots \ldots \ldots \ldots \ldots \ldots \ldots \ldots \ldots \ldots$ Chris Martin

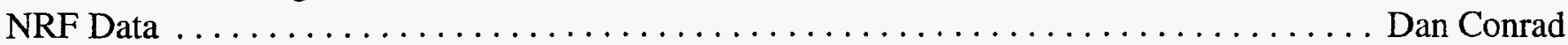
WINCO Drinking Water and Service Waste Data $\ldots \ldots \ldots \ldots \ldots \ldots \ldots \ldots \ldots$ Joan Neff Site Drinking Water Data . Brad Andersen Specific Manufacturing Capability Facility Information Richard Johnson Laboratory Intercomparison Data $\ldots \ldots \ldots \ldots \ldots$ Havis Harrison, Kim Shirley State of Idaho Monitoring Data Flint Hall 


\section{INTRODUCTION}

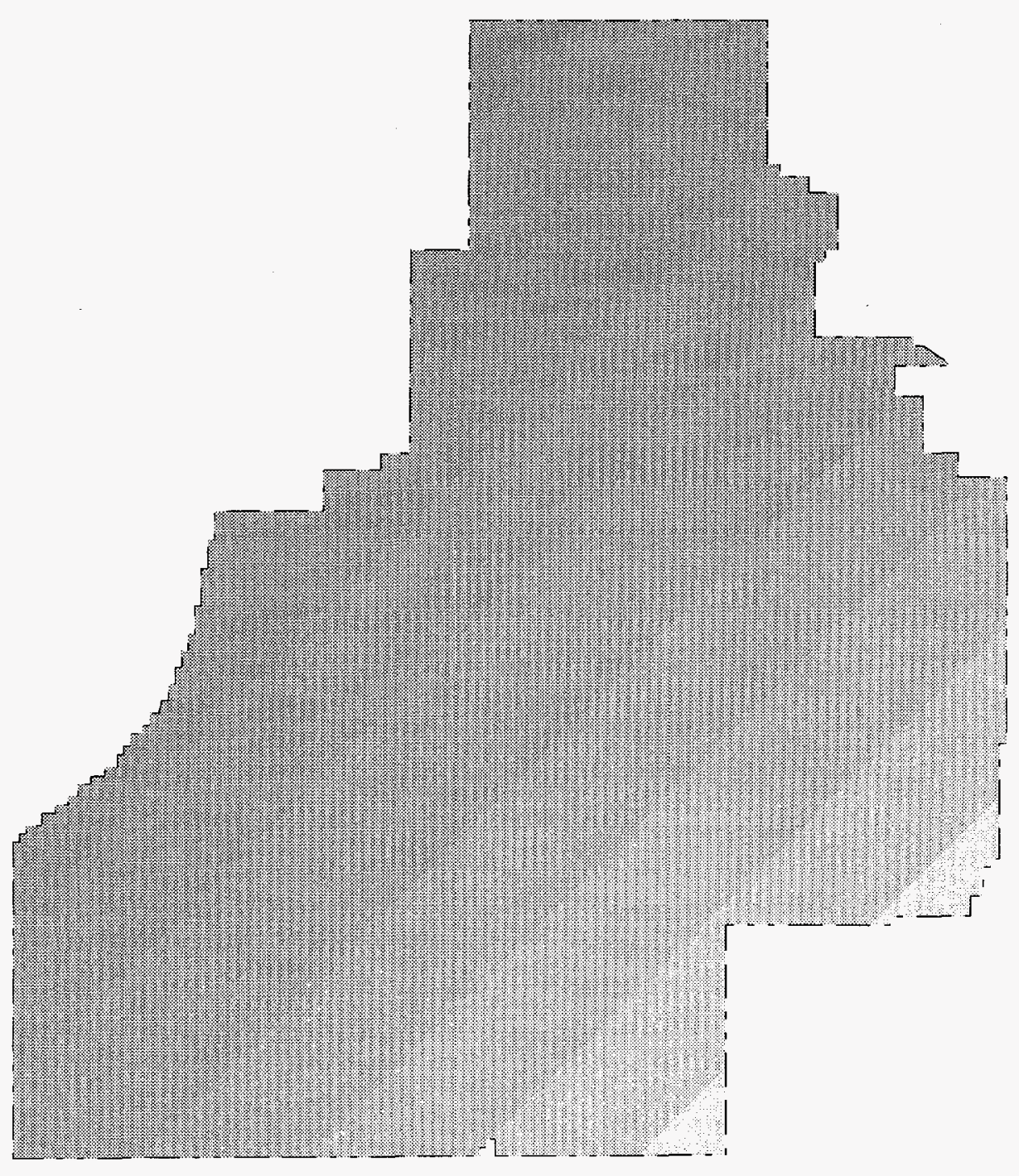




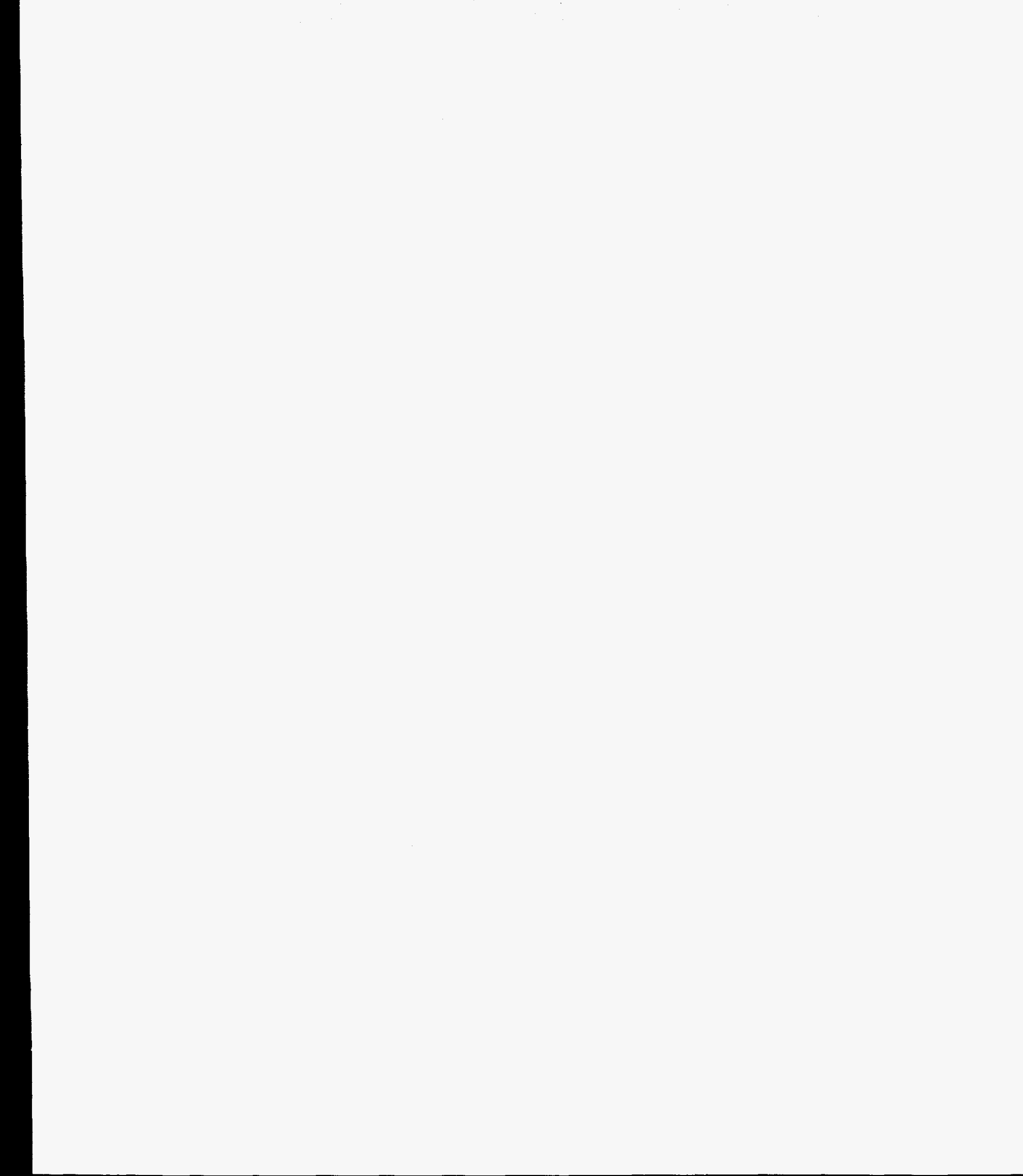




\section{INTRODUCTION}

\subsection{SITE DESCRIPTION}

\section{History}

The Idaho National Engineering Laboratory (INEL) of the U.S. Department of Energy (DOE) was established as the National Reactor Testing Station on the southeastern Idaho desert in 1949 to conduct research and further the development of nuclear reactors (Figure 1.1). Prior to that time, the area was known as the Naval Proving Grounds and was used as a testing range for naval guns from the U.S. Naval Ordnance Station in Pocatello, Idaho.

The first reactor built at the INEL, the Experimental Breeder Reactor-I, achieved initial criticality in December, 1951. The Site expanded rapidly in the 1950s with the establishment of the Test Reactor Area, the Naval Reactors Facility, and the Idaho Chemical Processing Plant, and with the development of the Aircraft Nuclear Propulsion program at the current Test Area North. In July, 1955 one of the reactors (BORAX III) became the first to light an American town [Arco, Idaho].

In 1974, the name was changed from the National Reactor Testing Station to the INEL to better reflect current projects, which include non-nuclear as well as nuclear projects. To date, 52 reactors have been built at the INEL, of which 14 are still operating or are operable.

\section{Physical Description}

The INEL is situated on the eastern Snake River Plain in southeastern Idaho at an average elevation of $1500 \mathrm{~m}(4900 \mathrm{ft})$. The Site encompasses $2300 \mathrm{~km}^{2}\left(890 \mathrm{mi}^{2}\right)$, extends 63 $\mathrm{km}(39 \mathrm{mi})$ from north to south and is about 58-km (36-mi) wide at its broader southern part. Land immediately beyond the boundaries of the INEL is either desert, foothills, or agricultural. Most of the nearby farming is concentrated northeast of the INEL. Large areas of agricultural land are farmed in the valleys adjacent to the Snake River, but these regions are more distant from the Site.

The plain where the NEL is located is part of a cool, desert-shrub biome.

Vegetation is typical of the Great Basin, with sagebrush conspicuous over $80 \%$ of the INEL.

The surface of the eastern Snake River Plain is composed of a sequence of basaltic lava flows extruded over the past two million years, partially covered by a veneer of sedimentary deposits. The sediment includes gravel and sand deposited by streams (as alluvial fans, channel fillings, and deltas), windblown sand, and silt and clay deposited in playa lakes. During the last glacial period, an ancient lake known as Lake Terreton covered 
approximately $233 \mathrm{~km}^{2}\left(35 \mathrm{mi}^{2}\right)$ of the northern INEL $^{\mathrm{a}}$.

Underlying the plain is the Snake River Plain Aquifer. Ground-water underflow from the Henry's Fork of the Snake River supplies a significant amount of water to the Snake River Plain Aquifer beneath the INEL. Additional recharge to the aquifer comes from the Big and Little Lost Rivers and Birch Creek drainages. These streams originate in the mountains to the northwest of the INEL. The Big Lost River and Birch Creek flow onto the INEL during wet years and sink into the porous soils. The underground water moves laterally at an average rate of 1.5 to $6 \mathrm{~m} / \mathrm{d}$ ( 5 to $20 \mathrm{ft} / \mathrm{d}$ ) to the south and west, and emerges in springs along the Snake River between Milner (located to the west of Burley) and Bliss, Idaho. Discharge volumes from typical springs in this region are approximately $4.3 \times 10^{9} \mathrm{~m}^{3}\left(3.5 \times 10^{6}\right.$ acre-ft $)$ per year. Both the ground and surface waters of the Snake River Plain are used for crop irrigation.

Average annual temperature at the INEL Central Facilities Area is $5.6^{\circ} \mathrm{C}\left(42^{\circ} \mathrm{F}\right)$, with extremes of $38^{\circ} \mathrm{C}\left(101^{\circ} \mathrm{F}\right)$ and $-44^{\circ} \mathrm{C}\left(-47^{\circ} \mathrm{F}\right)$. Annual precipitation in the area has averaged 22 $\mathrm{cm}$ (8.7 in.) over the past 15 years, peaking in late spring. Winds are predominantly along the southwest-northeast axis of the plain, with the most frequent and strongest winds from the southwest. The northeast winds are mostly nocturnal. Spring is the windiest time of the year, while winter has more calm periods and more nighttime temperature inversions $\mathrm{s}^{\mathrm{b}}$.

The nearest INEL boundaries are 35 $\mathrm{km}(22 \mathrm{mi})$ west of Idaho Falls, $37 \mathrm{~km}(23 \mathrm{mi})$ northwest of Blackfoot, $71 \mathrm{~km} \mathrm{(44} \mathrm{mi)}$

${ }^{a}$ S.J. Miller, INEL Management Plan for Cultura/ Resources, DOE/ID10361, March 1993.

${ }^{b}$ K.L. Clawson, G.E. Start, and N.R. Ricks, Climatography of the Idaho National Engineering Laboratory, 2nd Edition; DOE/ID-12118, December 1989. northwest of Pocatello, and $11 \mathrm{~km}(7 \mathrm{mi})$ east of Arco, Idaho (Figure 1.2). With a population of about 1100, Arco is the largest boundary community in the area surrounding the Site, and Atomic City (population 25) is the closest boundary community ${ }^{c}$. Approximately 121,500 people reside within a radius of $80 \mathrm{~km}(50 \mathrm{mi})$ of the Site's operational center, the TRA-ICPP area (Figure 1.3). There are no residents within $16 \mathrm{~km}(10 \mathrm{mi})$ of that center.

\subsection{INEL MISSION AND FACILITIES}

\section{Mission}

The mission of the INEL is to develop, demonstrate, and deploy advanced engineering technology and systems to improve U.S. competitiveness and security, the efficient production and use of energy, and the quality of life and the environment worldwide ${ }^{c}$.

\section{Facilities}

During 1994, significant changes occurred in the management of major facilities at the INEL. In August, DOE awarded the consolidated contract to Lockheed Idaho Technologies Company (LITCO). On October 1 , LITCO assumed control of most of the site operations, including facilities previously operated by EG\&G Idaho, Inc., Babcock and Wilcox, Idaho, Inc., and Westinghouse Idaho Nuclear Company. Facilities are located in Idaho Falls and at eight operating areas on the INEL (Figure 1.3). Major facilities are listed in the following sections.

\footnotetext{
' U.S. Department of Eriergy, Idaho Operations Office; 1994 INEL SiteSpecific Plan; DOE/ID-12053, 1993.
} 


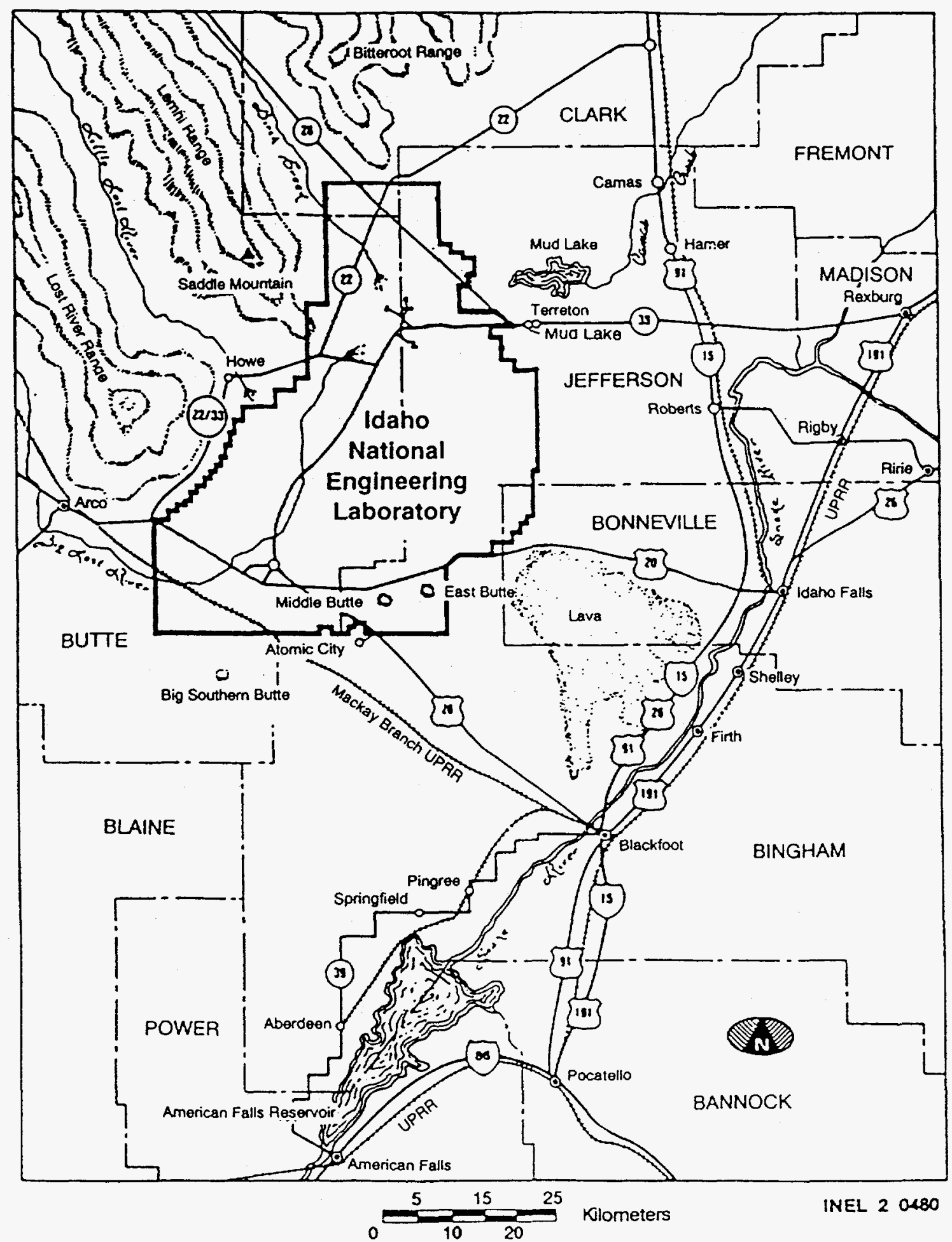

Figure 1.2 INEL Vicinity 
Argonne National Laboratory-West (ANL-W). This facility is operated by the University of Chicago's Argonne National Laboratory under contract to the DOE Chicago Field Office. At this site, ANL-W developed the Integral Fast Reactor, a new generation of breeder reactor that has advantages in safety and waste reduction. This project was terminated by Congress. Their new mission is to develop technologies for treatment of radioactive waste.

Idaho Chemical Processing Plant (ICPP). The ICPP, previously operated by Westinghouse Idaho Nuclear Company and now operated by LITCO, receives and stores nuclear fuels from the U.S. Navy and other activities. Technologies for treatment and disposal of high-level waste are being developed. High-level wastes are being treated and will ultimately be prepared for disposal in a permanent repository.

Test Area North (TAN). The largest program currently at TAN is the Specific Manufacturing Capability Project, previously operated by Babcock and Wilcox and now operated by LITCO. This project produces armor for the M1A1 Abrams tank. Other activities conducted at TAN include testing fuel storage casks, storing the Three Mile Island core debris, and dismantling lead-lined casks for recycling.

Test Reactor Area (TRA). The TRA has studied the effects of radiation on materials, fuels, and equipment for nearly 40 years. The Advanced Test Reactor has produced radioactive isotopes, and it can conduct nine environmentally controlled experiments simultaneously.

Power Burst Facility (PBF). The PBF area contains the Waste Experimental Reduction Facility (WERF) which processes low-level waste to reduce waste volume through sizing of metallic waste and compaction. There are plans to restart the incinerator at WERF in 1995 to treat low level and mixed low level wastes. The Mixed Waste Storage Facility is also located at the area.

Naval Reactors Facility (NRF). The NRF is operated by Westinghouse Electric Corporation for DOE's Pittsburgh Naval Reactors Office. From 1953 through 1994, NRF has served as a site for training Navy personnel who serve aboard nuclear-powered submarines and warships. NRF also has operating prototype plants used to examine and test naval reactor fuel components. The knowledge gained is used to improve current designs and to monitor the performance of existing reactors.

Radioactive Waste Management Complex (RWMC). The RWMC processes and disposes of radioactive wastes. The Stored Waste Examination Pilot Plant is used to nondestructively examine waste before it is sent to the Waste Isolation Pilot Plant in New Mexico. Pit 9 and Pad A are the sites for major ongoing cleanup efforts using new hightechnology strategies.

Central Facilities Area (CFA). Support services and laboratories for environmental monitoring and analytical chemistry are located at CFA. A DOE-ID laboratory, the Radiological and Environmental Sciences Laboratory (RESL) provides DOE complexwide laboratory accreditation and evaluation functions. The DOE Laboratory Accreditation Program for dosimetry and bioassay laboratories, and the Mixed Analyte Performance Evaluation Program are both conducted by RESL.

Idaho Falls. Idaho Falls facilities include the INEL Research Center, featuring a plasma research center, biotechnical center, and a 
materials research laboratory. The INEL computer systems, among them a CRAY Supercomputing Center offers a wide range of $\quad$ X-MP/216 supercomputer.

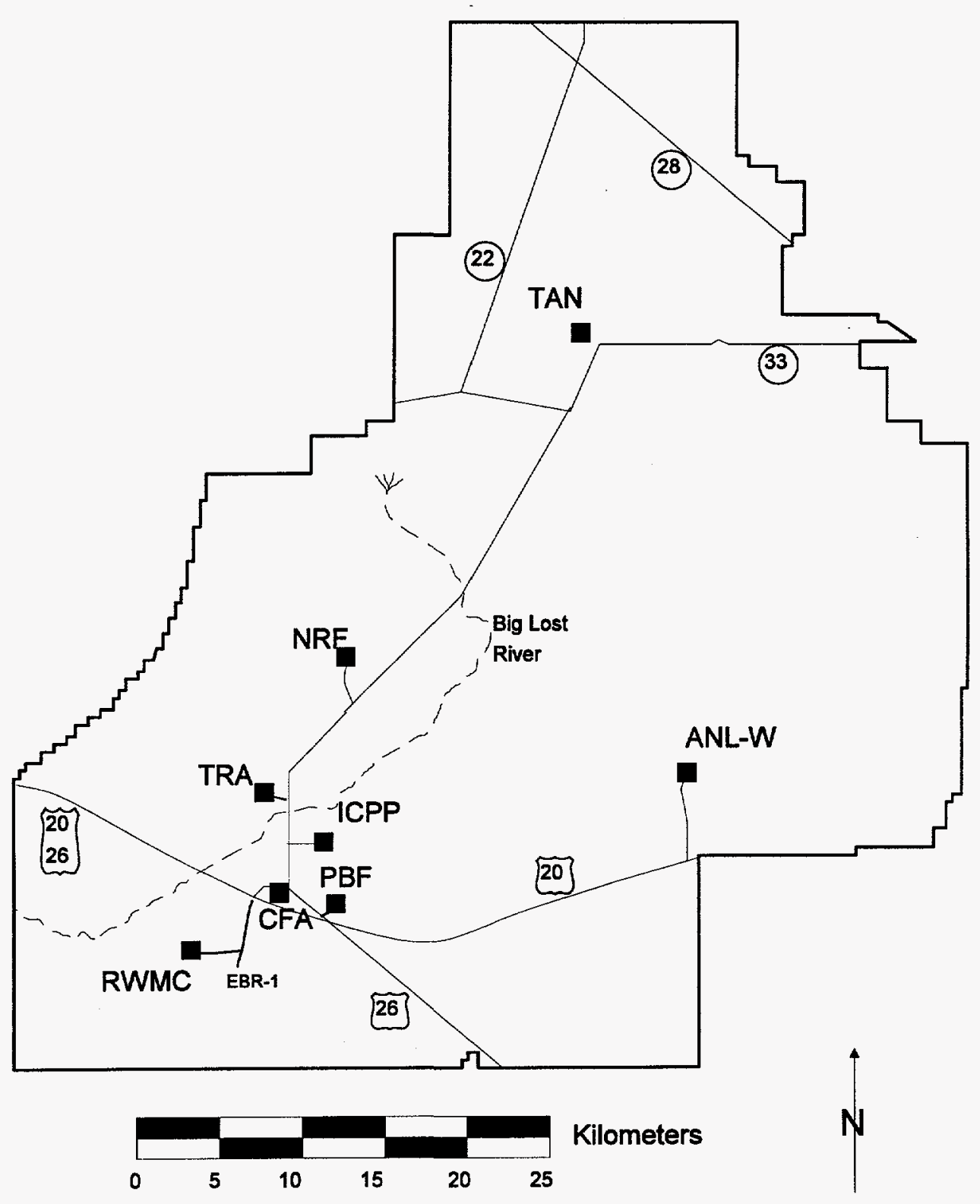

Figure 1.3 INEL Facilities 


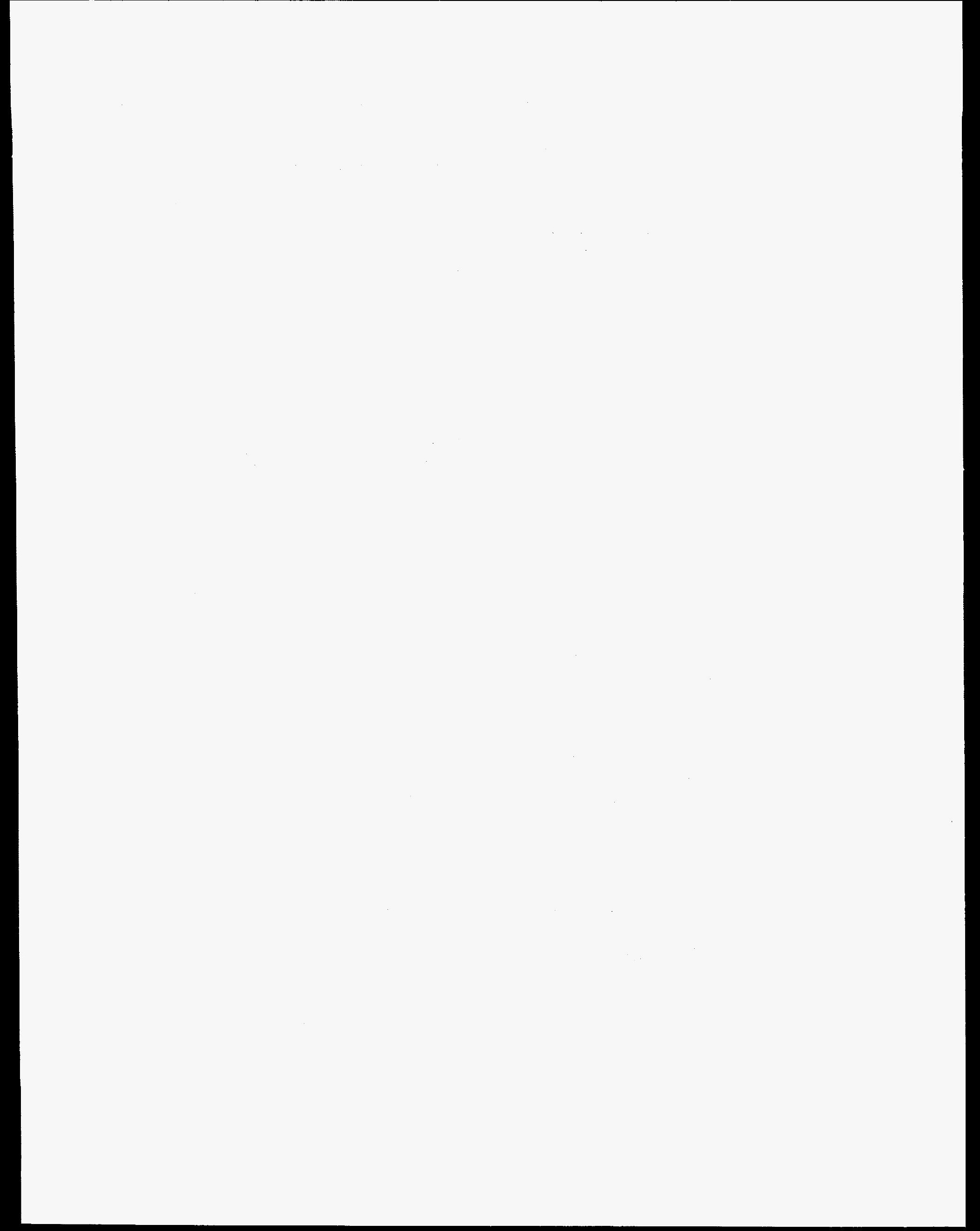




\section{ENVIRONMENTAL COMPLIANCE SUMMARY}

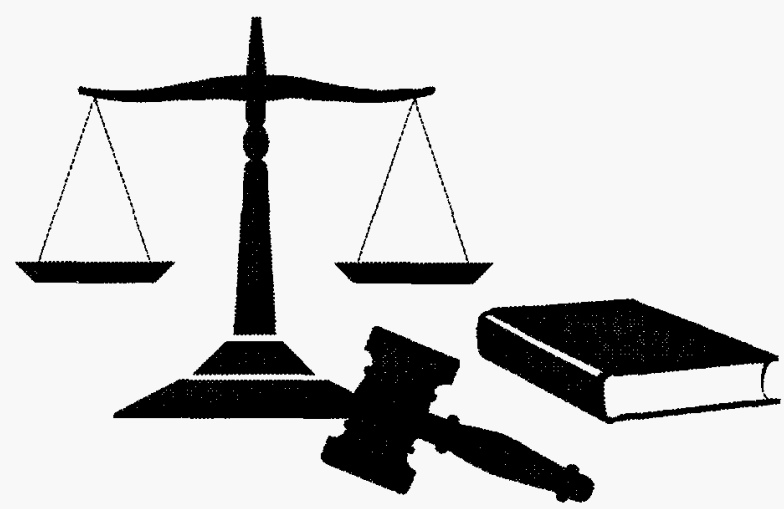





\section{ENVIRONMENTAL COMPLIANCE SUMMARY}

The INEL is committed to operating in compliance with all environmental laws, regulations, Executive Orders, DOE Orders, and compliance agreements with the Environmental Protection Agency (EPA) and the State of Idaho. The following is a summary of the INEL's current compliance status with major environmental statutes for the period January through December 1994. Environmental regulations are listed in Appendix A, Environmental Standards and Regulations.

\subsection{COMPLIANCE STATUS}

\section{Comprehensive Environmental Response, Compensation \& Liability Act (CERCLA)}

This Act provides the specific procedures to be used to assess and remediate inactive waste sites where the release of hazardous substances has occurred. The INEL was placed on the National Priorities List under CERCLA on November 29, 1989. Environmental restoration activities at the INEL are being conducted in accordance with the Federal Facilities Agreement and Consent Order (FFA/CO) signed in December 1991 in consultation with the State of Idaho and EPA Region 10.

During 1994, investigations under the FFA/CO continued to be streamlined under the processes outlined in the FFA/CO. Limited field investigations termed Track 1 and Track 2 are used in lieu of the more extensive Remedial Investigation/Feasibility Study to evaluate many potential release sites. A Track 1 is used for potential release sites where existing data are expected to be able to demonstrate that a site needs no further action. A Track 2 is used when limited field data collection is necessary. After each limited investigation is completed, a determination is made by the FFA/CO Project Managers that no further action is necessary or that proceeding with an interim cleanup action or further investigation under a Remedial Investigation/Feasibility Study is appropriate. By the end of 1994, such determinations had been made on $80 \%$ of the sites designated for Track 1 evaluation.

\section{Emergency Planning and Community Right-to-Know Act}

The purpose of this Act is to provide the public with information about hazardous chemicals on the INEL and establish emergency planning and notification procedures to protect the public from chemical releases. The Act also contains requirements for periodic reporting on hazardous chemicals stored and/or used at the facilities. The INEL complies fully with the Act's reporting requirements as outlined below.

311 Report. Quarterly updates to the INEL hazardous substance lists are submitted to the Local Emergency Planning Committees, the State Emergency Response Commission, and to local fire departments by January 1, April 1, July 1 , and October 1 each year. These updates satisfy the 90-day notice requirement for new chemicals brought on-site. 
312 Report. The Emergency and Hazardous Chemical Inventory (Tier II) Reports for the INEL were transmitted to the emergency planning agencies by March 1, 1994. These reports identify the types, quantities, and locations of hazardous and extremely hazardous chemicals stored at INEL facilities.

313 Report. The Toxic Chemical Release Inventory Reports were transmitted to EPA and the State of Idaho by July 1, 1994. These reports identified quantities of toxic chemicals which were released to the environment by the INEL during calendar year 1993. Reports were prepared for nitric acid, sulfuric acid, and methyl isobutyl ketone.

33/50 Report. Executive Order 12856 requires all Federal Agencies to comply with the EPA 33/50 program, requiring release reductions of 17 priority Toxic Chemical Release Inventory chemicals by $50 \%$ before the end of 1999. In 1994, the INEL filed a Toxic Release Inventory report for one priority chemical, methyl isobutyl ketone. Releases of methyl isobutyl ketone were down by $43 \%$ compared to the base reporting year of 1991. This decrease was primarily due to a reduction in operation of the process at the INEL which uses the chemical.

\section{Natural Resource Trusteeship \& Natural Resources Damage Assessment}

Executive Order 12580, Section 2(d), appoints the Secretary of Energy as the primary Federal Natural Resource Trustee for natural resources located on, over, or under land administered by DOE. Natural resource trustees act on behalf of the public when natural resources may be injured, destroyed, lost, or threatened as a result of the release of hazardous substance. Federal agencies, states, and Indian tribes are designated as natural resource trustees by National Contingency Plan Sections 300.600(b), 300.605, and 300.610 , respectively. In the case of the INEL, other potential natural resource trustees with possible jurisdiction over trust resources are the State of Idaho, Department of Interior (Bureau of Land Management and U.S. Fish and Wildlife Service), and Shoshone-Bannock Tribes.

Past releases of hazardous substances resulted in INEL's placement on the National Priorities List. These same releases create the potential for injury to natural resources. Therefore, in accordance with CERCLA, Section 104(b)(2) and National Contingency Plan 300.15(j), DOE-ID formally notified the other natural resource trustees of potential injury to natural resources in July 1992, and a meeting was held in March 1993 to discuss coordination between trustees and a proposal for formalizing a protocol addressing natural resource injury.

In April 1995, Lockheed Idaho Technologies Company (LITCO) published INEL-95/0190, Guidance Manual for Conducting Screening Level Ecological Risk Assessments at the INEL. This document supports the DOE schedules and milestones in the Federal Facilities Agreement/Consent Order for carrying out remedial investigation/feasibility study activities at the INEL. Integrating the natural resource concerns with these activities will provide for efficiency of efforts. Although the ecological risk assessment is a separate effort from the Natural Resources Damage Assessment, it is anticipated that the ecological assessment performed for the CERCLA remedial action can be used to resolve many natural resource 
issues among cognizant trustees as well. The regulation at 43 CFR Part 11, allows for this substitution ${ }^{\mathrm{a}}$.

\section{Clean Air Act}

General Information. The Clean Air Act sets standards for ambient air quality and for air emission of hazardous air pollutants. EPA is the federal regulatory agency of authority, but states may administer and enforce provisions of the Act by obtaining EPA approval of a State Implementation Plan. In August 1994, the Division of Environmental Quality of the State of Idaho prepared changes to the State Implementation Plan to make it compliant with November 1993 EPA rules.

The Permit to Construct may be required for any construction or modification of a facility that emits an air pollutant. Projects at the INEL that will result in emissions exceeding certain regulatory levels (i.e., major modifications) require Prevention of Significant Deterioration Permits to Construct. Applications for these permits require a more extensive analysis of the air pollutant emissións impacts.

Title V Operating Permit. Title V of the 1990 Clean Air Act Amendments required the EPA to develop a federally enforceable operating permit program for air pollution sources to be administered by the state and/or local air pollution agencies. The EPA promulgated regulations on July 21, 1992 which defined the requirements for the state programs. EPA approval of the State of Idaho program is expected about October 31, 1995.

\footnotetext{
a DOE, Natural Resource Trusteeship and Ecological Evaluation for Environmental Restoration at Department of Energy Facilities, DOE/EH-0192, June 1991.
}

A Title V work group has been established at the INEL to develop the Title V Permit application. This group consists of contractor and DOE-ID representatives. The application has been a four-year effort beginning with the initiation of the INEL emissions inventory of the entire Site to quantify emissions from all sources. This inventory provides the basis for the Title $\mathrm{V}$ application. The updated Air Emission Inventory for the Idaho National Engineering Laboratory, which included both criteria and toxic air pollutant inventories, was sent to the State in June of 1994.

LITCO submitted a draft of the application on April 17, 1995 for DOE-ID review and comment. The final Title $\mathrm{V}$ Permit Application is scheduled to be submitted to the State Division of Environmental Quality on July 31, 1995. The State has 60 days to review the Title $\mathrm{V}$ application for completeness. If the application is deemed administratively complete, the application shield will allow the INEL to operate under conditions of the application until such time as the actual operating permit is issued. The State has three years to issue the final permit.

Fuel Storage Area permit. The Air Permit for the Fuel Storage Area Rack Reconfiguration Project remains in suspension pending the Record of Decision for the Department of Energy Programmatic Spent Nuclear Fuel Management and INEL Environmental Restoration and Waste Management Environmental Impact Statement.

Procurement of new racks for the facility proceeded as allowed under the U.S. District Court's amended Court Order in the United States of America v. Andrus, dated December 22, 1993. The contract for rack design and fabrication was awarded to HOLTEC in 
January 1994, and the design and fabrication efforts are proceeding in parallel with the preparation of the Programmatic Spent Fuel Management and INEL Environmental Restoration and Waste Management Environmental Impact Statement. The goal is to be able to install the new racks in June 1995, if and when a favorable Record of Decision on the environmental impact statement is reached.

The State of Idaho INEL Oversight Office expressed concerns that the new racks were not designed in such a manner as to be suitable for use in other DOE facilities besides the INEL, nor were they needed by other sites. The DOE-ID Office of Chief Counsel responded to these concerns with specific information concerning other sites that need and can use this specific design.

Fuel Processing Restoration Permit. This permit imposes emission limitations on the now-defunct Fuel Processing Restoration project, the New Waste Calcining Facility, as well as existing fuel-burning sources (boilers) throughout the INEL. DOE-ID personnel met with the State of Idaho to discuss the status of the permit. As a result of the meeting, emission limitations for existing boilers must remain as is because these fuel-burning sources serve as the baseline for future Prevention of Significant Deterioration permitting.

An application requesting modification of the Fuel Processing Restoration permit was submitted on December 6, 1993 . Modifications include eliminating reference to the Fuel Processing Restoration project, eliminating the Nitrogen Oxide Abatement project, and increasing hourly emissions of nitrogen oxides from the New Waste Calcining Facility operations based on the maximum quantity specified in the permit application as long as the annual total does not exceed the 1700 tons/yr currently permitted. The permit application was approved on November 17, 1994.

Test Reactor Area Lined Warm Waste Pond. All concerns raised by the State of Idaho in 1993 related to the Permit to Construct the new, lined, warm waste pond were resolved; and the disposal of liquid effluents at the new pond began in August 1993. Remediation of the old, unlined pond was completed in March 1994. For more detailed information on the remediation, see Section 3.1 of this report.

\section{National Emission Standards for Hazardous Air Pollutants}

In June 1994, DOE-ID submitted the 1993 INEL National Emission Standards for Hazardous Air Pollutants--Radionuclides report to EPA, DOE Headquarters, and State of Idaho officials. The airborne radionuclide emissions (monitored, unmonitored, and diffuse sources) from INEL operations in 1993 were calculated to result in a maximum individual effective dose equivalent to a member of the public of $0.011 \mathrm{mrem} / \mathrm{yr}$ $\left(1.1 \times 10^{-4} \mathrm{mSv} / \mathrm{yr}\right)$ using the CAP- $88 \mathrm{com}-$ puter code. This dose was $0.1 \%$ of the regulatory standard of $10 \mathrm{mrem} / \mathrm{yr}$. The 1994 calculations with this code are discussed in Chapter 4, Environmental Radiological Program Information.

\section{Clean Water Act}

The Clean Water Act, originally passed in 1972, established goals to control pollutants discharged to U.S. surface waters. Among the main elements of the Act were effluent limitations set by the EPA for specific industry categories and water quality standards 
set by states. The Clean Water Act also provided for the National Pollutant Discharge Elimination System permit program, requiring permits for discharges from a point source into surface waters. An expansion of the National Pollutant Discharge Elimination System is underway with the issuance of storm water discharge permits to medium and large municipalities and sites with industrial activity.

Waters of the U.S. Delineation. In 1992, areas on the INEL that are potential "Waters of the U.S." were mapped and presented to EPA Region 10. These areas encompass what is called the Big Lost River system, which includes the Little Lost River, Birch Creek, the Big Lost River, and connecting tributaries and playas. In November 1993, the Army Corps of Engineers also designated the INEL Spreading Areas A and B near the Radioactive Waste Management Complex as Waters of the U.S.

Clean Water Act Section 404 Permits. DOE-ID sent a joint request in May 1994 to the U.S. Army Corps of Engineers and the Idaho Department of Water Resources for a Clean Water Act Section 404 permit to authorize work in Spreading Area B near the Radioactive Waste Management Complex. Spreading Area B is one of four depressions where water for flood control purposes is diverted from the Big Lost River. On October 5, 1994, the Army Corps of Engineers granted a ten-year Section 404 permit that authorizes DOE-ID to discharge dredged and fill material in waters of the U.S. associated with the excavation of soil material in Spreading Area $B$ at the INEL. An added condition of the permit includes prohibiting construction activity at sites eligible for listing on the National Register of Historic Places.
In another area of the INEL, a decision by the Army Corps of Engineers was made that the Birch Creek Playa at the Test Area North does not require a Section 404 permit for construction work and other borrow and fill work.

Spill Prevention Control and Countermeasure Plans. Evaluations were conducted in 1993 to determine which INEL facilities are required under 40 CFR 112 to have a Spill Prevention Control and Countermeasure Plan. Determinations were made as to which facilities required plans, and plans were prepared and updated for those facilities. Plans and determinations were documented in the INEL Spill Prevention Control and Countermeasure Plans and Exemptions, September 1994.

Oil Pollution Abatement. Evaluations were conducted to determine applicability of a proposed Oil Pollution Abatement rule revision published in the Federal Register (58 FR 8824 February 17, 1993). The proposed rule requires preparation and submittal of facility response plans for facilities determined to be "substantial harm" facilities. Based on the evaluations, it was concluded that there are none of these facilities at the INEL, and that the INEL, as a whole, is not a "substantial harm facility." A certification of no substantial harm was prepared during fiscal year 1994 and placed on file at the INEL.

\section{National Pollutant Discharge Elimination System Point Source Discharge Permits}

General. All INEL facilities were inventoried for point source discharges to Waters of the U.S. in 1992 and 1993. In October 1993, information obtained from Phase $I$ of the INEL Liquid Effluent Inventory and from 
evaluations conducted as part of the INEL Storm Water Pollution Prevention Plan (INEL SWPPP) for Industrial Activities was examined to identify any potential point source discharges. None were identified with the exception of the previously identified pressure relief discharges from ICPP production well pump stations to the Big Lost River. A permit application for the ICPP discharges was submitted to EPA Region 10 in 1992, but EPA concluded that the pollutant discharges were minor. EPA decided not to issue a permit at this time due to higher permitting priorities. ICPP is expected to comply with Idaho Water Quality Standards until a permit is issued at some time in the future, however. A revised permit application for these discharges as well as a new permit application for the new ICPP production well discharges will be submitted to EPA in 1995.

\section{Storm Water Discharge Permits for} Industrial Activity. The INEL applied for coverage under the General Permit for Storm Water Discharges Associated with Industrial Activity on September 28, 1992. The INEL SWPPP for industrial activities was completed on April 1, 1993 for all applicable areas and was implemented by October 1, 1993. Major facility area subsections are included in the INEL SWPPP. These plans will be kept on file and updated as necessary due to General Permit requirements. Annual inspections will be conducted by the SWPPP Team to determine compliance with the plans and the need for revision. Storm Water monitoring is conducted by the Lockheed Idaho Technologies Company Environmental Monitoring and Water Resources Group in accordance with the permit requirements and with DOE Orders. Procedures have been implemented with the National Oceanic and Atmospheric Adminstration's Air Resources Laboratory for identification and notification to DOE and contractor officials of storm events.

\section{Storm Water Discharge Permit for} Construction Activity. INEL submitted a Notice of Intent for coverage under the General Permit, and a generic INEL SWPPP for construction activities was prepared. This SWPPP affects any construction activity at the INEL after October 1, 1992. Construction includes clearing, grading, or excavation but does not include industrial activities. Facility area-specific SWPPPs have been prepared and list specific requirements for construction projects in a major facility area. Projects outside the major area are required to prepare a project-specific SWPPP. Again, procedures have been implemented with the National Oceanic and Atmospheric Administration for identification and notification of storm events.

\section{Executive Order 11990--Protection of Wetlands}

A plan has been developed, and funding allocated, to identify and field verify regulated wetlands at the INEL. This includes a prioritized schedule of areas or potential sites to be evaluated from fiscal year 1994 through fiscal year 1998. Sites delineated on the 1993 U.S. Fish and Wildlife Service INEL National Wetlands Inventory map will be included in the prioritization process. Other information gathered from previous field investigations is also used to establish the prioritized schedule. Proximity to facility operational areas, or sites that are currently being used, are given the highest priority.

The U.S. Fish and Wildlife Service National Wetlands Inventory map is used as a source of information to identify potential wetlands or nonregulated sites with 
ecological, environmental, or future development significance. National Wetlands Inventory sites that are clearly not wetlands will be eliminated from INEL inventory maps with the concurrence of the U.S. Fish and Wildlife Service. A DOE-ID policy is being developed that delineates how wetlands and other aquatic habitats will be managed at the INEL. Regulated wetlands will be added to the maps and will be identified in a manner that will clearly differentiate "regulated wetlands" from "nonregulated wetlands." Currently there are no identified operations at the INEL that are impacting regulated wetlands.

\section{Executive Order 11988--Floodplain Management}

In the fall of 1993, DOE-ID obtained stereographic aerial photographic coverage of INEL site areas judged to lie within the 100-yr floodplains of the Big Lost River and Birch Creek as an initial step in the production of a map of INEL floodplains. Early in 1994, DOE-ID gave approval to proceed with the remaining tasks in the floodplain mapping project. One early project task is using the aerial photographs to produce detailed topographic maps, an important prerequisite to mapping the floodplains. Personnel from the U.S. Geological Survey, Boise Office, began mapping tasks for the floodplain study in 1994. Maps of the 100-yr floodplains of the Big Lost River and Birch Creek, and a report documenting the floodplain study, are expected to be finished near the end of fiscal year 1996.

Although the floodplains of the Big Lost River and Birch Creek will be delineated by the present project, the project will not account for all areas on the INEL having a one-percent or greater chance of being flooded in any given year. Specifically, the study will not include areas that may be prone to flooding caused by runoff from local drainage basins. Such studies will have to be conducted separately. However, the detailed topographic maps to be produced by the current project will support such studies. In addition, the National Oceanic and Atmospheric Administration is expanding and updating its computations of annual, extreme, and return period precipitation to further support these studies.

\section{State of Idaho Wastewater Land Application Permits}

DOE-ID is obtaining State of Idaho Wastewater Land Application Permits for existing and future land application facilities (i.e. percolation ponds and sewage treatment irrigation systems). A final permit was issued by the State for the CFA Sewage Treatment Plant in July 1994. Final permits issued on March 17, 1995 for ICPP Percolation Ponds and Sewage Treatment Plant Rapid Infiltration Trenches were modified by the State to extend the effective permit dates to September 17, 1995. Alternative permit conditions are being negotiated in the interim.

Applications for Wastewater Land Application Permits are being prepared and are expected to be submitted to the State by December 15, 1995 for the following: Water Reactor Research Test Facility Sewage and Process Ponds at TAN, TRA Chemical Waste and Cold Waste Ponds, and the ANL-W Industrial Waste Pond. Applications for the Technical Support Facility Disposal Pond at TAN and the NRF Industrial Waste Ditch have been submitted to the State for review.

Other discharges to the land surface identified in the INEL Liquid Effluent Inventory will be evaluated to determine 
Wastewater Land Application Permit applicability by December 1, 1995.

\section{Resource Conservation and Recovery Act (RCRA)}

This Act establishes regulatory standards for the generation, transportation, storage, treatment, and disposal of hazardous waste. The State of Idaho is authorized by EPA to regulate hazardous waste and the hazardous component of radioactive mixed waste at the INEL. Strictly radioactive wastes are regulated by the Atomic Energy Act as administered through DOE orders.

Consent Order Status. Progress on the requirements of the Hazardous Waste Consent Orders of October 7, 1992 and April 3, 1992 is on schedule. The April 1992 Consent Order was recently modified on March 17, 1994 based on the U. S. District Court's amended order in United States of America v. Andrus, dated December 22, 1993. The Consent Order for the 1992 State of Idaho RCRA inspection of the INEL has been finalized, and the State of Idaho has terminated the Consent Order upon DOE's compliance with all its conditions.

On October 3, 1994, the State of Idaho sent DOE-ID a Notice of Violation for alleged violations noted in a September 1993 inspection. The Draft Consent Order for the inspection has been developed, and DOE-ID and the State are presently negotiating resolution of all alleged violations.

\section{RCRA Closures of Interim Status Units.} The State of Idaho approved RCRA closure plans for the Reactives Storage and Treatment Facility, The Idaho Chemical Processing Plant Hot Shop Storage Tank, and the IntermediateLevel Transuranic Facility. Those facilities were closed on August 11, 1994, July 23, 1994, and August 11, 1994, respectively.

RCRA Permitting Accomplishments. The INEL received a Hazardous Waste Partial Permit for the Hazardous Waste Storage Facility at CFA, and the Radioactive Sodium Storage Facility and the Radioactive Scrap and Waste Facility at ANL-W, effective January 24, 1994. On April 3, 1995, the INEL received a Hazardous Waste partial permit for the Hazardous Chemical Waste Handling and Neutralization Facility.

The INEL submitted two additional RCRA Part B applications (for four RCRA facilities) to the State of Idaho and responded to Notices of Deficiencies on three previouslysubmitted RCRA Part B applications.

RCRA Reports. As required by the State of Idaho, DOE-ID submitted the Idaho Hazardous Waste Generator Quarterly Reports for 1994. The reports contain information on waste generation, treatment, recycling, and disposal activities at INEL facilities for each quarter during 1994.

DOE-ID submitted the INEL 1994 Affirmative Procurement Report to EPA by December 1, 1994, as required by Section 6002 of RCRA and Executive Order 12780. The report provides information on the INEL's procurement of products containing recovered rather than virgin materials.

\section{Federal Facilities Compliance Act}

This Act, which amends RCRA, requires the preparation of site treatment plans for the cleanup of mixed (both radioactive and hazardous) wastes at the INEL. During 1994, the mixed waste inventory for the INEL was updated, the Draft Site Treatment Plan was completed and underwent a public comment 
period. Comments and concerns from the State of Idaho, EPA and members of the public were considered in the development of the INEL Proposed Site Treatment Plan, which was submitted to DOE-HQ in December 1994. The Proposed Plan was submitted to the State of Idaho and EPA in April 1995 and will be released for public comment. Any public comments on the Proposed Plan will be forwarded to the State. See Section 3.2 for more detailed information.

\section{National Environmental Policy Act (NEPA)}

Federal regulations require NEPA documentation showing that federal agencies have considered the environmental impacts of, and public comments on, proposed actions. This information must then be included in federal decision making. NEPA documentation can include a Categorical Exclusion, an Environmental Assessment or an Environmental Impact Statement (EIS). A Categorical Exclusion is a category of actions that do not individually or collectively have a significant effect on the human environment, and do not require either an Environmental Assessment or Environmental Impact Statement as followup. Due to a strategy of preparing generic or umbrella Categorical Exclusions, the number at the INEL dropped from 524 in 1992 to 319 in 1994.

The Secretary of Energy issued a Policy on NEPA on June 13, 1994 that significantly changed the way DOE did NEPA. For DOE-ID, elimination of the requirement to prepare NEPA documentation for CERCLA actions and a provision for delegating environmental assessment approval authority to DOE-ID were the most significant changes in 1994.
Delegation of environmental assessment approval authority required field offices to confirm that internal scoping procedures and public participation and quality assurance plans for NEPA had been prepared. On July 21, 1994, the NEPA Compliance Officer convened a Process Improvement Team to review DOE-ID's NEPA program and to prepare the required procedures and plans. The Team completed the procedures and plans and recommended establishment of a NEPA Planning Board. The DOE-ID management accepted the Team's recommendations in September 1994. DOE-ID requested environmental assessment approval authority from the DOE-Headquarters Office of Environmental Compliance on October 5, 1994 and that authority was conveyed to DOE-ID on October 26.

The DOE-ID Environmental Impact Statement Project Office, working under a court-ordered deadline, prepared the Draft DOE Programmatic Spent Nuclear Fuel Management and the INEL Environmental Restoration and Waste Management Programs Environmental Impact Statement (INEL-EIS). The Draft was issued by DOE-HQ on June 20,1994 . The public comment period was from June 24, 1994 to September 30, 1994, and more than 5,000 comments were received. The NEPA Compliance Officer was the lead technical specialist for ecology, cultural resources, land use and NEPA throughout the preparation of the INEL-EIS.

During December 1994, the EIS Project Office met with people who had provided technical comments on the document from several agencies and the Shoshone-Bannock Tribe. The meetings had several goals in mind: 1) to gain a better understanding of the substance of the comment; 2) to attempt to resolve the comments to the satisfaction of 
both commenter and DOE; and 3) to emphasize that DOE is receptive to resolving technical disputes through ongoing negotiation with the agencies and Tribes rather than through formal litigation. By the end of December, meetings had been completed with EPA, the Defense Nuclear Facilities Safety Board, the Shoshone-Bannock Tribes, and the Centers for Disease Control. All meetings were successful in reaching resolution of a significant number of comments, and commenters were pleased that DOE was making the effort to work with them The document was printed and distributed during April 1995.

In November 1994, the DOE-ID EIS Project Office received the Draft EIS for the Proposed Policy for Acceptance of Foreign Research Reactor Spent Nuclear Fuel. This document underwent DOE review prior to the release to the public in December 1994. Significant inconsistencies between the INEL-EIS and the Foreign Research Reactor EIS will need to be resolved before the latter is released. Litigation against the Foreign Reactor Research EIS is being pursued by various organizations seeking to halt shipments of spent nuclear fuel from European reactors.

DOE-ID is participating as a cooperating agency with the Bureau of Land Management and other federal and state agencies on an EIS named the "Southeast Regional Wastewater Treatment Plant Facilities Improvements Project and Geysers Effluent Pipeline Project Environmental Impact Statement." The geothermal project is located in Lake County, California and DOE is providing a portion of the funding for the project. The Bureau of Land Management signed their Record of Decision February 16, 1995, and DOE adopted the EIS January 11, 1995. DOE expects to issue a Record of Decision in early 1995.
Three Environmental Assessments were completed and Findings of No Significant Impact were issued during the first six months of 1994 for DOE-ID operations. They were for the expansion of the INEL Research Center project, the INEL Sewer System Upgrade project, and the INEL low-level and mixed waste processing.

DOE-ID released a Draft Environmental Assessment for the Waste Characterization Facility to the public in accordance with the Public Participation Plan prepared by the NEPA Process Improvement Team in the fall of 1994. The Draft Environmental Assessment was released to the State of Idaho, Tribes and general public for an open 30-day review period on November 18, 1994 . The comment period closed on December 20, 1994 and a Finding of No Significant Impact was issued on March 1, 1995.

\section{Safe Drinking Water Act}

The Safe Drinking Water Act establishes primary drinking water standards for water delivered by a public water supply system, defined as a system that supplies drinking water to either 15 or more connections or 25 individuals for at least 60 days per year. The INEL drinking water supplies meet those criteria and are referred to as nontransient noncommunity or transient noncommunity systems because persons who use the water do so five days per week but do not live at the Site.

On October 1, 1993, the State of Idaho instituted the assessment of fees for all public water systems to help the Idaho Division of Environmental Quality fund the State drinking water program. The INEL has twelve active public water systems that pay a fee to operate.

All INEL facilities performed the recommended sampling of drinking water for 
volatile organic chemicals and synthetic organic chemicals during 1993 in order to be eligible to replace annual sampling with a triennial sampling period. The State of Idaho was petitioned individually by each INEL public water system to grant waivers for the following: (a) dioxin sampling, because the chemical is not used at the INEL, (b) asbestos sampling based on previous analytical data showing the water is not contaminated with asbestos, and (c) sampling for synthetic organic compounds and volatile organic compounds and field measurements for $\mathrm{pH}$, temperature and conductivity measurements based on previous analytical data. These waivers are expected to result in a savings of approximately $\$ 100,000$ in the next three years. The State of Idaho DEQ granted each of the waivers.

The bacteriological program for drinking water at the INEL involves monthly testing for coliform bacteria. Further information on the results of this testing in 1994 may be found in Section 5.2, "Bacteriological Monitoring."

A new potable water well was drilled in 1993 at ICPP, but was not placed in service that year because construction of the well was not complete. The well was operational during 1994, but had limited use due to continuing construction problems. The potable water storage tank upgrade project planned for 1994 was delayed and construction actually began in March 1995 . It should be completed by the end of the summer.

\section{Toxic Substances Control Act}

This statute, which is administered by EPA, requires testing and regulation of chemical substances that enter the environment. The Toxic Substances Control Act supplements sections of the Clean Air Act, the
Clean Water Act, and the Occupational Safety and Health Act. Compliance with the Act at the INEL is primarily directed toward management of polychlorinated biphenyls (PCBs).

DOE-ID continues to store radioactively contaminated PCBs at the INEL and is in the process of developing a draft Compliance Agreement for negotiations with EPA Region 10. EPA Region 10 has been aware of the situation since their inspection in 1989. Negotiation issues include characterization, inspections, labeling, and one-year storage requirements. During 1994, DOE-ID submitted a permit application for a gamma degradation treatability study to determine if PCBs can be destroyed by high-energy gamma radiation. Tests using the TRA fuel cells as the gamma radiation source successfully reduced the concentration of PCB congeners (similar compounds) in hydraulic oil by an order of magnitude--from $5000 \mathrm{ppm}$ to 556 ppm. After the Toxic Substances Control Act Research and Development permit is approved by the EPA, tests using actual PCB wastes are planned. The test results are promising--the treatment destroys PCBs; it does not generate any additional waste; and it is relatively inexpensive when a source of gamma radiation is available.

\section{Federal Insecticide, Fungicide, and Rodenticide Act}

This Act governs the registration and use of pesticides (i.e. fungicides, herbicides, insecticides, and rodenticides. The INEL complies with the Act's requirements pertaining to storage and application of pesticides. There were no major activities or issues at the INEL with respect to this statute during 1994. 


\section{National Historic Preservation Act}

Preservation of historic properties ${ }^{\mathrm{b}}$ on lands managed by DOE is mandated under Section 106 of the National Historic Preservation Act. The Act requires that when any federal undertaking will have an adverse effect on an historic property, the cognizant federal agency must enter into an agreement with the State Historical Preservation Officer for the purpose of mitigating those adverse effects. During 1994, a Memorandum of Agreement was signed with the State Historical Preservation Officer permitting the Decontamination and Dismantlement of historically significant buildings at the Auxiliary Reactor Area I, II, and III facilities and clean up work at these areas was initiated.

Incident of Cave Disturbance. In July 1994, a non-INEL cave survey team, following up on an earlier study, requested permission to survey additional INEL caves for maternity colonies of Townsend's big-eared bats, a candidate species for the Threatened and Endangered Species List. The proposal was approved because information of this type is used in NEPA documentation on the INEL.

In January 1995, the survey team published in a club newsletter, an uncleared article with photographs that focused on human remains and archaeological artifacts in one of the caves. The disturbance of the specimens and the publication of the article compromised DOE's commitment to protect cultural resources on the INEL.

\footnotetext{
b As defined in the Act, "Historic property means any prehistoric or historic district, site, building, structure, or object included in, or eligible for inclusion in, the National Register. This term includes, for the purposes of these regulations, artifacts, records, and remains that are related to and located within such properties."
}

When DOE-ID became aware of the newsletter article, managers at DOE-ID commissioned a Task Force to investigate the incident. In March 1995, the Task Force reported results of its investigation and recommendations for changes in policy at the INEL to prevent such incidents in the future. The Shoshone-Bannock Tribes were consulted and kept fully informed throughout the process.

\section{Endangered Species Act}

Various federal statutes, such as the Endangered Species Act and Executive Orders, govern the protection of ecological and biological resources at the INEL. Federal agencies are required to monitor threatened and endangered species on their lands and to devise a management plan for each. It is also as important to study candidate and sensitive species to aid in the decision-making process related to whether or not to list the species, thereby impacting land-use issues. Several species that occur on the INEL are currently on various state and federal sensitive lists or have been declared candidates for federal listing.

In April 1994, the Environmental Science and Research Foundation assumed responsibility for ecological research, NEPA field evaluations of proposed project sites on the INEL that include assessment of the impacts on threatened and endangered species, and participation in surveys to determine the status of these species on the INEL. The Foundation semiannually contacts the U.S. Fish and Wildlife Service to update the INEL Threatened and Endangered Species List, which includes candidate and sensitive species. The November 1994 listing added four new candidate species: two species of bats, the burrowing owl, and the sagebrush 
lizard. The addition of the sagebrush lizard may not be appropriate according to experts in the region who confirm that this species is not in jeopardy in Idaho, and it will probably be removed from the list during the next evaluation.

Several species of birds of prey (raptors) are associated with the Threatened and Endangered Species List at the INEL. The bald eagle, which winters here, and the peregrine falcon, an occasional visitor, are both classified as endangered species. The ferruginous hawk and burrowing owl are candidates for listing. In early 1994, the Environmental Science and Research Foundation conducted the National Wildlife Federation bald eagle count for the state zone that includes the INEL. In the past, these surveys were instrumental in identifying seasonal and geographic use of the INEL by bald eagles. The annual eagle surveys were expanded in 1985 to record all raptors wintering on the INEL.

A study was completed in 1993 on the occurrence and microhabitat selection of the Townsend's big-eared bat, a candidate threatened species on the INEL. Data from the study are presented in two Master's degree theses. $^{\mathrm{a}}$ A February 1995 publication $^{\mathrm{b}}$ describes a survey of caves on the INEL, some of which support populations of bats at some time during the year. To protect the cave

\footnotetext{
a W. R. Bosworth, "Characteristics of Winter Activity in Plecotus townsendii in southern Idaho," M.S. Thesis, Idaho State University, Pocatello, Idaho, 1994. and R. W. Doering, "The Thermal Implications of Roost Site Selection in Hibernating Plecotus townsendii," M.S. Thesis, Idaho State University, Pocatello, Idaho, in preparation.

b S. Earl and R.C. Morris, A Survey of 14 Caves on the Idaho National Engineering Laboratory, Environmental Science \& Research Foundation, ESRF-006, February 1995.
}

resources, specific cave locations are not provided in the report.

Another study on a candidate species was initiated in January 1994 on the pygmy rabbit. The last pygmy rabbit study in this region was completed in 1978. Readers interested in more details on ecological research at the INEL may refer to a November 1994 listing of publications that have resulted from research conducted by the Foundation, the former DOE-ID Radioecology and Ecology Program, and university affiliates. The report ${ }^{\mathrm{c}}$ lists 332 publications resulting from research conducted by these programs from 1974 through 1994.

\subsection{OTHER MAJOR ENVIRONMENTAL ISSUES AND ACTIVITIES}

\section{Fort St. Vrain Litigation}

On December 22, 1993, the U.S. District Court issued its order approving the stipulation previously agreed to by the State of Idaho, the Secretary of the Navy, and the Secretary of Energy. The amended Court Order was entered by the Court after the Ninth Circuit Court of Appeals held that the trial court had abused its discretion by modifying the terms of the stipulation in an earlier order. The amended order required DOE-ID to renegotiate the administrative Notice of Noncompliance Consent Order with the State of Idaho. This task was completed on schedule and signed by the DOE-ID Acting Manager in early March 1994.

\footnotetext{
c R. C. Morris, Radioecology and Ecology Publications of the Idaho National Engineering Laboratory: 1974-1994, Environmental Science and Research Foundation, ESRF003, November 1994.
} 
The latest order allowed a limited number of shipments of spent fuel to enter the INEL pending completion of the INEL-EIS. In addition, the order set accelerated milestones for the preparation of the INEL-EIS; removal of spent fuel from ICPP Building 603 and placement in ICPP Building 666; and treatment, storage and disposal of high-level radioactive wastes. All 1994 court-ordered milestones were met before or on scheduled dates.

\section{Ground-water Monitoring Program Activities}

The INEL Ground-water Monitoring Plan, written in accordance with DOE Order 5400.1, was completed in June 1993. The plan establishes the framework for ensuring compliance with all regulatory and DOE standards which require ground-water monitoring. The plan documents the INEL's regional and facility area-specific groundwater monitoring needs and documents the ground-water monitoring networks and sampling programs that must be developed to meet those needs. Implementation of the plan was initiated in 1993 and continued in 1994. The ground-water monitoring network was completed at the Auxiliary Reactor Area, and work was initiated on the ground-water network at PBF. Evaluations were conducted in 1994 to further refine unit- or facilityspecific ground-water monitoring needs. It is anticipated that the plan will be fully implemented by the year 2004 .

In 1993, a physical survey of all wells at the INEL was completed; and each wellhead was evaluated and, where necessary, upgraded. A "fitness" evaluation of all wells at the INEL was completed to determine whether the wells meet applicable state and federal well construction standards. Deficient wells are being prioritized and upgraded or abandoned as funding becomes available.

\section{Health Studies}

In December 1991, the Secretary of Energy and the Secretary of the Department of Health and Human Services signed a Memorandum of Understanding which transferred authority for the conduct and management of all epidemiological studies at DOE facilities to the Department of Health and Human Services.

INEL Dose Reconstruction Study. The INEL Environmental Dose Reconstruction Project is being conducted by an independent agency, the National Center for Environmental Health. In December 1994, Sanford Cohen \& Associates completed Phase I of the Dose Reconstruction. Phase I identified and evaluated the documents and data at the INEL pertinent to a historical dose reconstruction. The results are contained in an 800-page report and an electronic data base of about 75,000 pages.

Epidemiological Study of Workers at the INEL. The INEL epidemiological study of workers, which will evaluate patterns of mortality in all workers at the INEL since 1949 , is being conducted by the National Institute for Occupational Safety and Health (NIOSH).

The primary objective of this study is to assess potential associations between exposures to ionizing radiation and/or other toxic elements in the INEL worksite and mortality in the workforce. To meet this objective, NIOSH will conduct an all-cause epidemiological cohort mortality study and will evaluate the feasibility of a prospective cancer incidence study among INEL 
employees. Detailed exposure histories will be compiled for all workers using records from health physics and industrial hygiene at the INEL. During 1994, NIOSH investigators constructed a roster of current and past INEL employees, began reviewing records at the INEL, and are compiling a complete list of documents of potential interest in assessing both radiological and chemical exposures.

\section{Human Radiation Experiments Study}

As a result of questions raised by the media, federal agencies were directed in January 1994 to inventory and retrieve records pertaining to human radiations experiments. In support of this effort DOE-ID established a Human Radiation Experiments Team. During 1994, a records inventory was performed and searches of pertinent records for information on human radiation experiments at the INEL (formerly named the National Reactor Testing Station) were initiated. In February 1995, DOE-HQ published a report, Human Radiation Experiments: The Department of Energy Roadmap to the Story and the Records (DOE-EH-0445). This report provides information on human radiation experiments performed at the INEL as well as experiments performed at other DOE facilities. It also provides information on experiments involving intentional releases of radioactivity to the environment.

Two human radiation experiments that were initiated at Idaho National Engineering Laboratory have been identified. The experiments were not classified or performed in secret. Approximately 39 volunteers were involved in the two experiments. The volunteers in both experiments were employees of the U.S. Atomic Energy Commission. Although signed consent forms have not been found in all cases, a consent process, based on the principles of the Nuremberg Code, was used.

The first experiment was the Controlled Environmental Radioiodine Tests, which were designed to develop models for predicting the movement of radioiodine through milk to the human food chain. As part of some of the tests conducted between 1963 and 1966, volunteers drank milk or inhaled air containing radioiodine to obtain data on the transport of radioiodine to and through the body. Radioiodine was carefully measured in air and milk, as was the resulting radiation dose to the thyroids of the volunteers. Those thyroid doses were less than one-tenth of the occupational radiation protection guides in effect at the time, and less than one-fifth of the radiation protection standards for the general public in effect today.

The second experiment involved administration of radioactive material to volunteers for testing and calibrating whole body radiation counters.

\section{Tiger Team Assessment Corrective Actions}

In June 1989, the Secretary of Energy announced an initiative to strengthen safety, environmental protection, and waste management activities at DOE production, research, and testing facilities. A Tiger Team assessment was conducted at the INEL during June and July of 1991 and the team's report listed a number of concerns and findings in four major areas: 1) Environmental; 2) Management and Operations; 3) Occupational Safety and Health; and 4) Overall safety and health. No findings were characterized as representing an imminent danger.

The DOE-ID and its contractors developed corrective action plans to address findings and concerns and have worked on 
closing activities as time and resources permit. Recently, more than 100 plans for findings at the Argonne facility were transferred to DOEChicago for tracking and resolution because the facility is not a DOE-ID contractor. During 1995, DOE-ID intends to examine and re-evaluate Tiger Team action plans that remain open and to close those no longer applicable to operations at the INEL. The contractor consolidation and modifications to facility missions occurring during 1994 have made some corrective action plans unnecessary.

\section{Environmental Occurrences}

The Clean Air Act of 1990 made ethylene glycol releases greater than one pound reportable under CERCLA. In 1994, releases between one pint and five gallons of ethylene glycol occurred at the INEL on January 21, February 3, February 14, March 14, April 13, October 31, and November 21. The releases were absorbed and disposed of as required. Proper notifications were made in all cases.

On October 12, 1993, approximately 1540 gallons of \#2 fuel oil were released at the CFA tank farm. The spill was caused by an open valve on a drain line from the fuel tank. The release was reported to the State of Idaho. A plan for bioremediation of the area was submitted to and accepted by the State of Idaho. Bioremediation of the spill area is in progress.

Sampling of effluent from the INEL Research Center and the Willow Creek Building located in Idaho Falls identified discharges which exceeded the Idaho Falls sewer code limits for various chemicals in January, February, April, and July of 1994.

Petroleum product releases to the environment occurred during 1994 in quantities ranging from 5 gallons to 125 gallons on January 19, July 19, and July 21.
An "alert" condition was declared at ANL-W, Building 754 (the drinking water pump house) in April 1994. This situation involved a leak of the chlorine gas used for the water purification. The leak was quickly stopped, but ANL-W employees were evacuated and INEL emergency organizations responded to the area. About 15 ANL-W workers were examined for possible injury due to chlorine inhalation, but only one was held overnight at the hospital and subsequently released. There was no health or safety hazard to members of the public. The incident triggered inspections at facilities DOE-wide and at some area businesses to ensure that they could avoid similar problems.

\section{Summary of 1994 Environmental Restoration \& Waste Management Activities}

The following items represent a capsulized summary of events and activities at the INEL related to the Environmental Restoration and the Waste Management Programs for 1994. For a more complete discussion of these items, see Sections 3.1 and 3.2 of this report.

- Record of Decision signed for NRF landfills and Industrial Waste Ditch

- Records of Decision signed for Pad A and for Organic Contamination of Vadose Zone project at the Radioactive Waste Management Complex

- Pit 9 clean-up contract awarded, site preparation began in December 1994

- Interim Action remediation activities at TRA Warm Waste Pond completed in 1994 
- Interim action initiated on TAN Injection Well. Action suspended after several months while EPA, DOE-ID, and State of Idaho consider expansion of preferred alternative

- Unexploded Ordnance Removal Action at two sites initiated during 1994.

- Removal actions completed for settling basin and dry well at ICPP and for Laboratory Container Disposal Area near the Technical Support Facility at TAN. Others at CFA and TAN Technical Support Facility are partially complete.

- Proposed INEL Site Treatment Plan for Federal Facilities Compliance Act submitted to the DOE-HQ and the State of Idaho on schedule

- Decontamination/Dismantlement/Demolition activities completed in 1994: CFA Hot Laundry Facility; Auxiliary Reactor Area-II Buildings 602, 613, and 601; TAN-607 Decon Shop; CFA-605; TAN Initial Engine Test facility structures; Closure of TAN-606 Calibration Well and TAN Drainage Disposal Well \#4. A major 1994 effort, the CFA-654 Maintenance Shop demolition, was completed in early 1995.

- Interim Action remediation completed for the Power Burst Facility Evaporation Pond and Corrosive Waste Sump

\section{Environmental Oversight \& Monitoring Agreement}

Negotiations continue to finalize language for a new five-year agreement with the State of Idaho for environmental monitoring at the INEL. While those negotiations continue, the present language and grant were extended through the end of calendar year 1995. Analytical data from the State Oversight Office environmental surveillance program confirmed that no contamination from INEL operations was detected offsite during 1994.

The State of Idaho has conducted several research and development activities since the inception of the signing of the Environmental Oversight and Monitoring Agreement in 1989. Those activities are expected to be completed by the end of calendar year 1995 .

\section{The Environmental Management Site Specific Advisory Board -- Idaho National Engineering Laboratory}

The INEL Site Specific Advisory Board was formed in March 1994 after a lengthy design and selection process. The first meeting was held in May of 1994. The Board's charter is to provide input and recommendations on Environmental Management strategic decisions that impact future use, risk management, economic development, and budget prioritization activities. In addition, the Board provides advice on any other Environmental Restoration and Waste Management projects which the Assistant Secretary, the Director of the Office of Public Accountability, or DOE field site manager assigns to the Board for review and advice.

The INEL Site Specific Advisory Board's initial meetings concentrated on board structure and charter, the Federal Advisory Committee Act, board procedures, board budget, and initial training in radiation and spent nuclear fuel topics. Time was also spent touring INEL facilities. The Board quickly moved to identify the top five DOE/EPA/State issues, with the first issue tackled being the 
review of the draft INEL-EIS. The Board issued a formal recommendation to DOE-ID on this draft EIS in September 1994. In October 1994, the Site Specific Advisory Board provided comments to DOE-ID on the INEL Community Relations Plan. The final major 1994 issue addressed was the Federal Facility Compliance Act's Draft Site Treatment Plan on which the Board made a formal recommendation to DOE-ID in December 1994.

\subsection{PERMITS}

Permits that have been granted to the INEL and those for which applications have been submitted are summarized in Table 2.1. The RCRA units now operating with a RCRA Hazardous Waste Partial Permit include: the Hazardous Waste Storage Facility at CFA, the Radioactive Sodium Storage Facility at ANL-W, the Radioactive Scrap and Waste Facility at ANL-W, and the Hazardous Chemical Waste Handling and Neutralization Facility, which was granted a permit in April 1995.

One Wastewater Land Application Permit was granted on July 25, 1994 for the CFA Sewage Treatment Plant. The INEL applied for one Well Construction Permit, covering 36 wells, that was granted by the State of Idaho in 1994.
The Idaho Department of Water Resources has granted Underground Injection Control permits allowing the continued operation of eight deep injection wells (defined as Class V under 40 CFR 144.6) at the INEL. These wells are used for draining excess surface water runoff. One permit application (TAN Drainage Disposal Well \#4) was denied based on the well's close proximity to a bulk fuel storage area. DOE-ID agreed to abandon this well in accordance with the State of Idaho well abandonment regulations. The well was closed and sealed with grout on May 25, 1994.

\begin{tabular}{|c|c|c|c|}
\hline \multicolumn{4}{|c|}{$\begin{array}{c}\text { Table } 2.1 \\
\text { Permit Summary for the INEL (1994) }\end{array}$} \\
\hline Permit Type & Issuing Agency & Granted & Pending \\
\hline PTC/PSD ${ }^{a}$ & Idaho $\mathrm{DEQ}^{\mathrm{b}}$ & 24 & 4 \\
\hline BRC $^{\mathrm{c}}$ & Idaho DEQ & 42 & 2 \\
\hline NESHAP & EPA Region 10 & 27 & 0 \\
\hline Operating Permit & Idaho DEQ & 0 & 1 \\
\hline \multicolumn{4}{|l|}{ Groundwater } \\
\hline & EPA Region 10 & 2 & 2 \\
\hline & Idaho DWR ${ }^{\mathrm{d}}$ & 8 & 0 \\
\hline Well Construction & State of Idaho & $1(36)$ & 0 \\
\hline WLAP & Idaho DEQ & 1 & 8 \\
\hline \multicolumn{4}{|l|}{ RCRA } \\
\hline \multirow{2}{*}{$\begin{array}{c}\text { Part A } \\
\text { Part B }\end{array}$} & State of Idaho & 1 & 0 \\
\hline & State of Idaho & 3 & 11 \\
\hline \multicolumn{4}{|c|}{$\begin{array}{l}\text { Permit to Construct/Prevention of Significant Deterioration. } \\
\text { Division of Environmental Quality. } \\
\text { Below Regulatory Concern. } \\
\text { Department of Water Resources. } \\
\text { To date, seven volumes have been submitted to the State of Idaho. }\end{array}$} \\
\hline
\end{tabular}




\section{ENVIRONMENTAL PROGRAM INFORMATION}

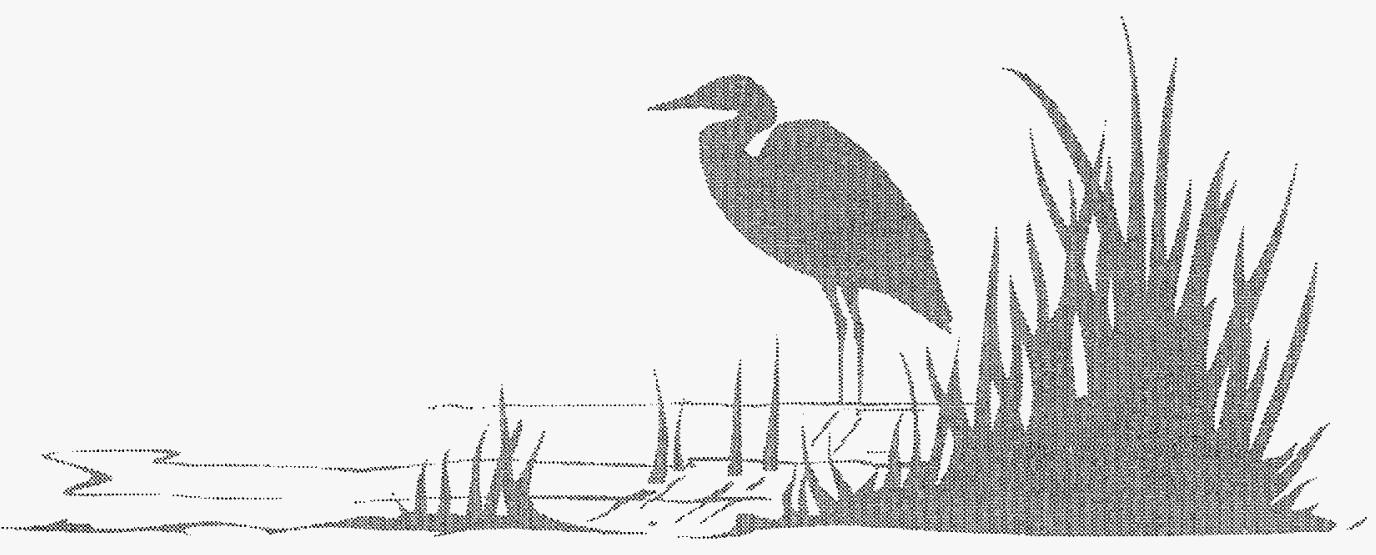





\section{ENVIRONMENTAL PROGRAM INFORMATION}

\subsection{ENVIRONMENTAL RESTORATION PROGRAM}

\section{General Information}

A common public perception of environmental restoration activities is that all investigations are expensive and timeconsuming. However, streamlining of Environmental Restoration activities at the INEL by DOE, EPA, and the State of Idaho has saved millions of dollars. This streamlining is accomplished due to the flexibility and management principles established under the Federal Facilities Act/Consent Order such as:

- $\quad$ Making cleanup decisions as soon as data are sufficient to do so

- Using existing data to the fullest extent possible

- $\quad$ Reducing to a minimum the duplication of analyses and documentation

- Matching the level of investigation to the level of complexity of each release site

One example of the implementation of these principles is performing limited field investigations (termed Track $1 \mathrm{~s}$ and Track $2 \mathrm{~s}$ in the Consent Order) in lieu of the more extensive remedial investigation/feasibility studies (RI/FS) where appropriate. After each limited field investigation, a determination is made that no further action is necessary, that an interim action remediation is appropriate, or that further investigation in an RI/FS is needed. This approach greatly reduces the number of major investigations that need to be conducted.

\section{Remedial Investigation/Feasibility Studies}

Argonne National Laboratory-West. ANL-W will begin its comprehensive RI/FS in June 1995. Preliminary data were collected in the Fall of 1994 for this investigation. No contaminants have been discovered in the Snake River Plain Aquifer attributable to ANL-W activities. A monitoring well installed during 1994 showed no perched water zones, and earlier U.S. Geological Survey studies have detected none in the few observation wells they have in the ANL-W area.

SL-1/BORAX Burial Grounds. This RI/FS was based on historical monitoring data and on computer modeling of contaminants remaining in the site. Risk calculations were made and presented for a public comment period just completed in May 1995. The draft Record of Decision is scheduled for late 1995.

Central Facilities Area Landfills. The field work for the CFA Landfills RI/FS was completed in the summer of 1993, and the final report was issued in February 1995. The public comment period for the proposed Plan closed on May 26, 1995. The Record of Decision is scheduled to be signed in November 1995.

Test Area North Gound Water. The RI/FS, which deals with the organic contamination plume associated with an injection well at TAN, was completed in 1994. DOE-ID is currently negotiating the Record of Decision with EPA and the State of Idaho. 


\section{Records of Decision}

Pad A. The Record of Decision for Pad A at the RWMC was signed by DOE-ID, EPA, and the State of Idaho with the final signature occurring on February 17, 1994. The selected alternative was Limited Action. The Remedial Design/Remedial Action Workplan was finalized in July and recontouring activities associated with Pad A began during mid September. The first phase activities included placement of additional soil for slope correction, addition of rock armoring to one side of the Pad and reseeding. The second phase activities, scheduled to be completed early in 1995 include drilling one horizontal bore hole and installing two lysimeters and one neutron access tube (moisture monitoring devices) under the Pad, installing four neutron access tubes and one lysimeter to monitor water movement through the cover, and sampling of soils.

\section{Remedial Action for the Organic} Contamination in the Vadose Zone . DOE, EPA and the State of Idaho signed a Record of Decision agreeing to use the vapor vacuum extraction technology for remediation of the vadose zone at RWMC. The decision became final on December 2, 1994. The vadose zone is the area between the land surface and the top of the water table into which organic vapors were released when buried drums containing volatile organic compounds, such as degreasers and solvents, deteriorated over time. The three agencies agreed to take action because small quantities of the contaminants had already reached the Snake River Plain Aquifer. The concentrations within the aquifer are below drinking water standards and there is not considered to be a significant health risk to workers from drinking the water of the production well at the RWMC.
Under the conditions of the December 2, 1994 Record of Decision, the existing vapor vacuum extraction well that supported the 1993 small-scale test system and five additional vapor extraction wells will be used to remove the organic vapors. Additionally, ten monitoring wells were installed to evaluate the effectiveness of the system. The extracted vapors will be treated to destroy the organic contaminants.

Naval Reactors Facility. The DOE, EPA, and State of Idaho signed a Record of Decision for ten sites at the NRF. Nine of the sites were landfills primarily used for office trash, construction debris, and municipal waste at various times from the 1950s through the 1970s. The agencies agreed that six of the landfills required no further action and that three should be covered with a native soil cover. A sampling program was instituted to monitor groundwater and soil gases for the three landfills to be covered. Soil samples and soil gas surveys detected low levels of volatile organic compounds in two of the three landfills, and low levels of barium and mercury in the third. The tenth site at NRF is a 3.2-mile long ditch that receives nonradioactive waste water. The agencies agreed that no further action is necessary for the ditch based on a Remedial Investigation. Public meetings were held in Idaho Falls, Boise, and Moscow during April 1994 to discuss the Proposed Plan with the public.

Power Burst Facility. In June 1994, DOEID again met with EPA and the State to discuss scoping of work at two Waste Area Group 5 operable units. These sites include PBF and surrounding injection wells, seepage pits, and leach ponds. Agreement was reached with both EPA and the State of Idaho on the scope and contents of the Track 2 summary 
reports. Most of these sites will be closed out with no further action recommended based on previous sampling results and anticipated health risks from the sites. The six Track 2 summary reports were sent for concurrence to the State and EPA in November 1994, but there has been no response at this time.

Auxiliary Reactor Area. A Track 2 summary report of the ARA area was sent to the State of Idaho and EPA in July 1994. The report recommends that there be no further action at the ARA-IV Contaminated Leach Pit \#1, and that a comprehensive remedial investigation/feasibility study be done of the ARA-III Radwaste Leach Pond. A letter of concurrence was received from the State of Idaho in early 1995.

\section{Remediation/Restoration Activities}

Removal Actions. Removal actions are usually performed when soil, equipment and other items are contaminated, but pose no immediate danger to workers in the area. Removing the substances prevents any longterm threat to workers or the environment.

Central Facilities Area Dry Pond.-During the summer of $1994217 \mathrm{~m}^{3}\left(285 \mathrm{yd}^{3}\right)$ of simulated calcine material and soil contaminated with mercury and small amounts of radioactive tracers was removed from a dry pond near building CFA-674 as part of a Superfund removal action. The contaminated material was placed in closed containers beside the pond to await treatment. A private subcontractor will recover the mercury from the calcine material and soil during 1995. They will use a thermal recovery process known as retort technology. While the technology is present at the INEL, it will also be used to treat the material from the TAN
Removal Action described in the next paragraph. The recovered mercury will be sold commercially or used by DOE, and the treated soil will be returned to the dry pond.

Test Area North Technical Support Facility Railroad Spur.--Field work at the TAN Technical Support Facility mercury removal site was completed in November 1994. The site is located at the railroad spur adjacent to the TAN-607 decontamination shop and consists of the rail bed and soil extending three feet on each side of the tracks. During the 1950s and 1960s, elemental mercury was used as radiation shielding in the Heat Transfer Reactor Experiment-III engine. Contamination is believed to have occurred as these engines were transported along the track. In a 1993 field screening survey, elevated levels of mercury vapors were found along two sections of the railroad track. About 120 $\mathrm{yd}^{3}$ of mercury-contaminated soil and gravel were removed from the site during August and September 1994. Upon receipt of laboratory confirmation samples, the site was backfilled with clean soil. The contaminated soil was placed in boxes beside the site and will be treated with the private subcontractor's retort technology system while it is at the INEL to treat soil at the CFA Dry Pond site.

In the process of field work at the mercury removal site, two radioactive particles with counts of 2,000 and 40,000 counts per minute, respectively, were found beneath a railroad tie. Both particles were safely removed, and no further action is anticipated. The rail line was used to support the U.S. Air Force Aircraft Nuclear Propulsion project during the 1955-1961 engine tests. The particles were probably derived from components of that project that were transported to the TAN decontamination shop along the rail line. 
Idaho Chemical Processing Plant Removal Actions.--There were two removal actions at the ICPP during 1994. The first involved pumping radioactively contaminated sludge and liquid from two settling basins east of spent fuel storage building, CPP-603. The sludge and water came from a filtration system used for basin water where spent nuclear fuel rods were stored. The sludge was dried and taken to RWMC for disposal. The low-level radioactively contaminated liquid removed from the settling basin was treated in ICPP's Process Equipment Waste Evaporator system.

The second removal action involved the removal of nonradiological simulated calcine material from a vessel off-gas line. After flushing the line with a solution of nitric acid and aluminum nitrate, samples were collected and analyzed. Contaminants remaining in the line were below regulatory limits.

\section{Test Area North Technical Support Facility Laboratory Container Disposal Area.--Records indicated that miscellaneous bottles and cans were placed in a small disposal area about 300 feet east of the TAN gravel pit in the early 1960s when the metallurgical laboratory in TAN-607 was cleaned up. Although the $40^{\prime}$ by $60^{\prime}$ rec- tangular site was excavated to a depth of 4 feet by the subcontractor, only seven bottles and three cans were recovered--a total of about one cubic foot of waste. Remediation of the site was successfully completed in July 1994. Verification soil samples were taken from the excavation and the roll-off bin and documen- tation photographs of the recovered materials were taken. The site was graded and reseeded.}

Pit 9 Decision.--During 1993, the U.S. Department of Energy, EPA and State of
Idaho officials signed a Record of Decision for Pit 9 at the RWMC. Pit 9 is an inactive disposal pit covering about 1 acre. Most of the waste in the pit originated at the Rocky Flats Plant in Colorado and the INEL.

Lockheed Environmental Systems and Technologies was awarded the contract to clean up Pit 9 in October 1994. This is the first privatized environmental remediation project of its kind at a DOE facility. It provides DOE with several significant advantages, including cost savings, demonstrating technologies that may be applicable to other DOE sites and achieving a more rapid clean up of waste sites. The Pit 9 remediation will allow field-testing of technologies for retrieving and treating low-level radioactive waste and transuranic mixed waste (waste containing both radioactive and nonradioactive hazardous chemical components.) The technologies, with little or no modifications, may then be applied to similar wastes buried and stored at other DOE facilities around the country to reduce future costs associated with technology development. Modular facilities successfully demonstrated at the INEL would also eliminate the need for designing and constructing permanent remediation facilities at each DOE site.

Lockheed Environmental Systems and Technologies, a Houston-based subsidiary of Lockheed Corporation, will use remote retrieval technologies to safely remove soils and waste from Pit 9 , separate radionuclides and hazardous chemical wastes from soils, destroy the organics and transform the remaining waste into a glass-like material which exceeds waste disposal requirements.

In early December 1994, site preparation and grading for the Pit 9 treatment facility was begun. The treatment facility design is expected to be complete in March 1996 with all construction completed by May 
1996. From August to December 1996, the contractor will conduct a limited production test where a small amount of simulated and actual Pit 9 waste will be processed. If successful, Lockheed will proceed with fullscale remediation. Cleanup of Pit 9 is scheduled to be completed in Feburary 1998.

Power Burst Facility Corrosive Waste Sump and Evaporation Pond Interim Action.--From 1978 to 1985, the PBF corrosive waste sump was used during the neutralization of spent reactor secondary coolant water prior to discharge to the evaporation pond. Heavy metals and radionuclides contaminated the inside of the sump. The draft Remedial Design Work Plan was submitted to the EPA and the State of Idaho Department of Health and Welfare in 1993. Sediments contaminated with chromium and radionuclides were removed from the pond in 1994, placed in closed containers, and shipped to RWMC. This removal action reduced the risk of workers and the public to exposure by windblown contamination. In late 1994, hazardous sludge was removed from the sump, dried, packaged and stored at the Mixed Waste Storage Facility until a treatability study is completed. The study will determine what technique should be used to stabilize the sludge to meet waste acceptance criteria for disposal at the RWMC. In its present condition, the chromium in the sludge is leachable and cannot be disposed at the complex.

\section{Test Reactor Area Warm Waste} Pond.--In August 1993, the unlined pond near TRA that had received discharges of radioactive wastewater for more than 40 years was replaced by a lined warm (radioactive) waste pond. The old pond was remediated by placing a clean fill over the contaminated sediments of the pond and backfilling the remainder of the pond to grade with clean fill material. A clean soil cover was then placed over the entire area and it was seeded with natural vegetation seed mix. Cleanup field activities at the pond began in October 1993, were completed in March 1994, and the project was closed out in June 1994.

Test Area North Injection Well.--In 1993, cleanup activities were begun on the TAN Injection Well that was used from 1953 to 1972 to discharge liquid wastes into the fractured basalt of the Snake River Plain Aquifer. Those wastes included organic, inorganic, and low-level radioactive wastewaters that were added to industrial and sanitary wastewaters. The resulting waste plume contaminated some of the drinking water wells that had been used by TAN workers. Since discovery of the contamination, drinking water has been treated in order to meet drinking water standards, and untreated water is not accessible to workers or the general public.

An interim action was deemed necessary to remove the sources of contamination that could further impact the Snake River Plain Aquifer. A subcontract was awarded for the design, construction, and operation of a Groundwater Treatment Facility and the interim action was initiated in March 1994 to pump and treat the TAN injection well water for removal of the primary contaminant of concern, trichloroethylene. However, after operating the Groundwater Treatment Facility for several months, the agencies learned that (a) levels of contaminants are up to three times higher than previously known; (b) other potential contaminants of concern are present; and (c) the facility was not specifically designed to treat some of these additional contaminants. Due to these factors, the agencies decided to temporarily suspend 
operation of the treatment facility and are considering expanding the preferred alternative for the groundwater contamination by adding three new tasks: (a) sampling and analysis of the injection well water to better characterize the contamination; (b) testing for removal of ${ }^{137} \mathrm{Cs}$ and other radionuclides; and (c) surging and stressing of the injection well to remove as much bulk contaminated material as possible.

A separate remedial investigation/feasibility study to investigate groundwater contamination in areas beyond the injection well was completed in 1994. The draft Final Record of Decision for TAN groundwater remediation was transferred to the State of Idaho and EPA on November 21, 1994. The document incorporated agency comments and revisions agreed upon earlier. A Fact Sheet, documenting changes to the Record of Decision, was published in January 1995 in an effort to maintain the Environmental Restoration Program policy to keep the public fully informed at all times.

Unexploded Ordnance Projects.-Unexploded ordnance items at the INEL were the result of past activities associated with the former Naval Proving Ground. Prior to 1949, the Navy conducted aerial bombing practice, naval artillery testing, explosives storage bunker testing, and ordnance disposal at a large portion of what is now the INEL. The EPA, DOE and State of Idaho have addressed the effects of past ordnance activities by planning an interim action, a removal action, a Track 2 investigation, and a project that was to use bioremediation techniques to clean up TNT and RDX contaminated soil at a facility used by the National Oceanic and Atmospheric Administration. The latter project was deferred until the bioremediation technology options, which involve the use of micro- organisms and their natural processes to break down organic contaminants into less hazardous compounds, have been evaluated during the Track 2 investigation.

The interim action project to locate and detonate unexploded ordnance items resulting from past activities associated with the former Naval Proving Ground, which included areas near CFA, ICPP and in the central corridor of the INEL was completed by the end of 1993. The project was undertaken because the ordnance items presented a hazard to personnel who frequented those areas. Soil contaminated as a result of past and recent detonations was removed for off-site incineration at an EPA-approved commercial facility.

A removal action to clean up unexploded ordnance at the Twin Buttes Bombing Range and the Naval Ordnance Disposal Area was initiated during the 1994 field season. The Removal Action was projected to be completed during the spring of 1995 , but this is contingent upon available funding and evaluation of remedial options. If it is not completed in the spring, the area will be controlled and cleaned up following the Track 2 investigation.

The Track 2 investigation, scheduled to begin in October 1995, will address INEL areas where unexploded ordnance and soils contaminated with explosive residues have not been inventoried and are poorly defined due to incomplete historical records. These potentially contaminated locations, INEL-wide, will be evaluated during the investigation, and bioremediation technologies will also be evaluated.

\section{Decontamination/Dismantlement/ Demolition Activities}

High Praise. An INEL article featuring the Decontamination and Dismantlement work at 
the INEL appeared in Demolition Age Magazine. The article was the cover story on a Demo Age special issue focusing on radiation work. According to the magazine's editor, he received great feedback and calls from Oak Ridge, Los Alamos and other DOE facilities. The editor sent a copy of the publication to the DOE Secretary of Energy, Hazel O'Leary with a note stating that her people in Idaho are doing a "great job."

\section{Central Facilities Area Hot Laundry}

Facility. This facility laundered anticontamination clothing from all INEL facilities from the early 1950 s to the early 1980s. The decontamination and dismantlement activities were begun in 1993 with the removal of the contaminated roof. By the middle of June 1994, all activities had been completed including the removal of a single story concrete block building, footings and foundations, excavation of underground piping, removal of a $17,000-\mathrm{kg}(37,000-\mathrm{lb})$ boiler, and removal of asbestos, and other hazardous materials. Much of the structure and the boiler were sent to the CFA Landfill for disposal or were recycled. The independent verification contractor completed all soil sampling from the former building pad and the open excavation on June 28,1994 . The site was reseeded, and the final report on the project was completed January 1995.

Auxiliary Reactor Area-II. All buildings at the ARA-II facility were demolished to grade in 1994. The ARA-II area including the SL-1 burial ground will remain under institutional or administrative control due to the presence of radioactively contaminated materials below the surface of the ground.

Auxiliary Reactor Area-III. In April 1994, a heater that had been used to heat primary coolant gas during start-up of the gas-cooled reactor at ARA-III was removed to a staging area where the asbestos and contaminated heater tube bundles were removed. By the end of August the rest of the FY-94 scope of work for this project had been completed. Demolition of all buildings is scheduled for completion in mid FY-95.

Auxiliary Reactor Area-IV. A subcontractor completed the removal of the $30^{\prime} \times 31^{\prime} \times 3^{\prime}$ volume of radiologically contaminated soil at ARA-IV. The excavation was surveyed, found to be clean and backfilled to grade with clean soil.

Test Area North-607 Decon Shop. This former decontamination shop was cleaned up during 1994 and was returned to the Landlord. Later, LITCO began to use the cleaned shop to dismantle lead-shielded casks for the lead management program.

\section{Surplus Facility Inventory and Assessment} Project. DOE-Headquarters accepted the inventory of all the buildings and structures at the INEL during 1994, and plans were begun to demolish surplus facilities.

Central Facilities Area-605.--The old Materials Test Lab built by the navy in the early 1940s was the first facility to be demolished under the surplus facilities project. Although the structure was not radiologically contaminated, asbestos tile, roofing panels, pipe insulation, and window caulking presented unique challenges in the demolition of this single story concrete block structure. All the demolition material was reduced in size and sent to the CFA Landfill for disposal. The entire effort took about 4 weeks and was complete in early August 1994. 
Test Area North Initial Engine Test Project.--This facility supported work during the Aircraft Nuclear Propulsion Program and the High Temperature Reactor Experiments. The facility's five structures were the next slated for demolition and work began in late August 1994 and was completed by the end of September 1994. The project included demolition of a guard house, transfer pumping building, a liquid tank building, and a weather tower and substation. It also included the removal of perimeter power poles and underground piping. Asbestos removal from several structures was required. Recyclable material is being stored at ARA-III for future disposition.

Central Facilities Area-654 Maintenance Shop.--This facility was condemned in 1993 due to major structural deterioration, and the roof started to sag at an increased rate during the summer of 1994 . The building contained a substantial amount of asbestos that could not be removed until roof jacks were installed to shore up the building trusses to allow workers to safely enter the building. The entire project, including demolition of the building and fill and leveling activities, was completed by March 1995 .

\section{Public Involvement in Environmental Restoration Program Activities}

The INEL Community Relations Plan, which outlines how DOE will involve citizens in the CERCLA process, was rewritten to respond to public comments on the September 1991 version of the plan. The September 1994 draft version is a compilation of four years of interaction between the public, EPA, DOE, and the State of Idaho. Included in the revised document is earlier public involvement in the cleanup process and more public involvement opportunities. DOE-ID initiated a 60-day public comment period on the current draft Plan between October 10 and December 10, 1994.

Semiannual public briefings were held in Twin Falls, Idaho in April and in October 1994 at Moscow, Boise, and Idaho Falls, Idaho to provide information about the status of cleanup projects and to provide information and seek input on other current issues. An Open House was held in April 1994 at a Pocatello mall to provide opportunities for public input on the proposed plan for Organic Contamination in the Vadose Zone at RWMC and the proposed plans for NRF. The Open House was followed by public meetings for the projects in Idaho Falls and Twin Falls. Public meetings to summarize information and seek public comment on remediation alternatives proposed for reducing contamination in TAN groundwater and 31 No Further Action sites were held in Idaho Falls, Boise and Moscow, Idaho in June 1994. Additionally, tours of INEL facilities and presentations to schools and civic organizations by the Public Affairs Speakers Bureau have been used to increase public understanding of INEL activities.

Articles in the INEL Reporter (a publicly available newsletter) also provided updates on Environmental Restoration Program activities, and in 1995, the Community Relations Plan published Kickoff Fact Sheets and Update Fact Sheets which include details on various remedial projects at the INEL's Waste Area Groups. 


\subsection{WASTE MANAGEMENT PROGRAM}

\section{General Information}

The goals of the waste management program are to manage wastes at the INEL, ensuring that workers and the public are protected, and that the environment is not further impacted. INEL waste management activities consist of (a) reducing the total amount of wastes generated; (b) treating wastes already generated by reducing their toxicity, mobility, or volume; (c) disposing of wastes; and (d) storing wastes awaiting development of new disposal or treatment options.

Another challenge faced in managing wastes at the INEL is involving the citizens of Idaho in the search for answers and resolutions to significant waste management issues. A variety of methods are used to keep the public informed about INEL activities and involved in decision-making. See the last subsection of Section 3.1 Environmental Restoration Program for more information.

\section{Waste Management Program Accomplishments for 1994}

The Federal Facility Compliance Act. This act, which amends RCRA, requires the preparation of site treatment plans for the clean up of mixed wastes containing both radioactive and nonradioactive hazardous materials at the INEL. The Conceptual Site Treatment Plan and the Draft Site Treatment Plan were submitted to the State of Idaho by the scheduled dates. The first draft of the INEL Proposed Site Treatment Plan was sent to DOE-Headquarters for review and approval early in December 1994 and was submitted to the State of Idaho and EPA in April 1995. The INEL Proposed Site Treatment Plan will be released for public comment in 1995, and those comments will be forwarded to the State. This Plan outlines DOE-ID's proposed treatment strategy for INEL mixed waste streams and provides a preliminary analysis of potential offsite mixed low-level waste treatment capabilities. The final plan will form the basis for State of Idaho and DOE consent order negotiations for mixed waste treatment at the INEL.

Public involvement in the Federal Facilities Compliance Act activities at the INEL has been integrated into the overall public participation program already in place for environmental restoration and waste management activities. Public Focus Group meetings were held on the Conceptual Site Treatment Plan in 1993; and briefings on the Draft Site Treatment Plan were held in 1994 in Twin Falls, Boise, Moscow and Idaho Falls to solicit public opinion early in the process. DOE also briefed the Environmental Management Site-Specific Advisory Board-INEL, a local citizen's review board on the Draft Plan, and responded to its comments and concerns.

Mixed Waste Lead Laboratory. DOEHeadquarters announced on December 19, 1994 that the INEL had been selected as lead organization for mixed waste technology development. DOE-ID, supported by Lockheed-Martin Idaho Technologies, will coordinate the national effort to treat mixed waste. The task will include coordinating the development of technologies to characterize, treat and dispose of mixed low-level and mixed transuranic wastes. At the INEL alone, there is enough mixed waste to fill about 600 railroad boxcars. 
Resource Conservation and Recovery Act Activities. Those activities related to the permitting of hazardous wastes at the INEL are discussed under the RCRA title in the "Environmental Compliance Summary," Section 2 , of this report.

\section{Waste Experimental Reduction Facility} Restart Program. The Waste Experimental Reduction Facility, which was shut down for safety improvements in February 1991, was restarted and began sizing and compacting low-level waste in November 1994. There are plans to restart the incinerator at the facility in 1995 after the Record of Decision for the INEL-EIS has been signed. The incinerator will be used initially to treat low-level wastes, and by the end of the year is scheduled to begin incineration of mixed low-level wastes currently stored at the INEL. The compacted materials, and the ash from the incinerator will be disposed of at RWMC.

National Low Level Waste Management Program. Technical support was provided for the commercial low level waste disposal siting and disposal facility development in several states including Nebraska, California, Texas, Pennsylvania, and North Carolina. Work began with the DOE Office of Civilian Radioactive Waste to establish the Yucca Mountain, Nevada repository as the final resting place for waste that does not meet Nuclear Regulatory Commission criteria for shallow land burial disposal that is known as Greater-Than-Class-C waste. This is waste that also does not fall into the high level waste category and is, therefore, an "orphan" for which DOE has a legal obligation for disposal.

Radioactive Waste Technical Support Program. This LITCO department provided support to DOE headquarters organizations on development of the Baseline Environmental Management Report prepared for submittal to Congress in April, 1995. Development work was done on DOE Order $5820.2 \mathrm{~B}$, a revision of the order governing management of $\mathrm{DOE}$ waste. Support was also provided for the Waste Management Programmatic EIS, Activity Data Sheet review, and risk-based decision-making efforts undertaken by DOE.

\section{Waste Minimization/Pollution Prevention}

General. Key approaches to meeting Waste Management Program goals are waste minimization and pollution prevention programs. Some current activities of the waste minimization and pollution prevention programs at the INEL include: (a) identifying, screening, and analyzing options to reduce the generation of waste; (b) listing unused and excess chemicals and materials in the Material Exchange Program as available for use in other projects or facilities; (c) using the database on which hazardous solvents are tracked to identify and substitute nonhazardous solvents when possible; (d) practicing sitewide recycling of paper, wood, glass, metal, plastic, cardboard, beverage cans, used oil, electronic components, antifreeze, some solvents, and batteries; (e) substituting reusable and nonhazardous materials for hazardous and disposable materials when possible in the site equipment and vehicle maintenance programs; (f) sharing pollution prevention lessons learned at the INEL with surrounding communities and industry; and (g) examining production processes within the INEL to determine whether improvements in process efficiency can result in a significant source reduction of wastes. 
Re-use of Excess Materials. The INEL transferred $50 \mathrm{~kg}$ of normal uranium and 51 $\mathrm{kg}$ of depleted uranium to Schenectady Naval Reactors Plant. The materials are excess to INEL programs at ICPP and were listed on an excess nuclear materials bulletin for potential use by another DOE program.

Deuterium from the INEL Research Center was shipped to Idaho State University in Pocatello, Idaho to support research activities that include the Boron Neutron Capture Therapy Program. Some is scheduled to be shipped to the National Institute of Health in support of medical research during fiscal year 1995.

A custom process product from ICPP was transferred to the Oak Ridge National Laboratory Y-12 Plant in July 1994. An additional 22 shipments of scrap nuclear material are scheduled during the next three years.

Arrangements have been made to transfer excess beryllium from the PANTEX plant in Texas and Oak Ridge National Laboratory in Tennessee to the INEL for future operations at TRA. Use of this excess material from other DOE facilities will result in savings of more than $\$ 2$ million dollars to the INEL.

Lead Management Project. The INEL Lead Management Project assures appropriate and uniform operations and management of waste lead at the INEL, ensures the lead supply is managed and stored in approved facilities, and implements treatment processes and technologies for recovery, storage, or disposal.

\section{Cask Dismantlement.--A} demonstration program conducted by Babcock $\&$ Wilcox Idaho proved that spent nuclear fuel transfer casks could be safely dismantled and the lead shielding recovered. With com- pletion of the demonstration, Babcock and Wilcox Idaho and EG\&G Idaho began a twoyear pilot program to dismantle 20 more casks of various configurations to provide information and experience for eventual dismantlement of all out-of-service casks at the INEL (and possibly other DOE sites). An evaluation of the program in early September revealed that dismantlement of 20 casks (completed one year ahead of schedule) was done at a lower total cost than projected for the ten casks that were planned for Fiscal Year 1994. Results from analyses performed on samples taken from the 55,000 lbs. of lead retrieved from the casks dismantled in 1994, certify that $50,000 \mathrm{lbs}$ are free of DOE added radiological contamination and suitable for free release recycling. The lead is currently stored in the Clean Lead Facility.

Lead Brick Surface Decontamination.--Private sector contractors, RUST Federal Services and Chem-Nuclear, processed 40,000 lbs of lead brick from the INEL to remove surface contamination. About $32,000 \mathrm{lbs}$ passed criteria for being radiologically clean after the first cycle. RUST will continue and complete a second cleaning cycle of the $8,000 \mathrm{lbs}$ that did not pass the criteria, and they will treat all waste streams generated by the process in 1995 .

Re-use of Lead Shot.--About 13.5 tons of mixed low-level waste contaminated lead shot was transferred to ANL-W for use in shielding new tanks instead of occupying valuable storage space at the RWMC. While the cost of retrieving and installing the contaminated lead is about the same as the cost of new lead, reuse of this material will avoid generation of additional tons of mixed waste lead and will provide storage for a substantial period. 
Lead Waste Minimization.--The Lead Management Project became aware of large amounts of lead-shielded cables at the INEL that are no longer in use and are candidates for disposal or waste minimization activities. Specifics associated with performing the work to excess or recycle the lead shielded cables are being identified and evaluated, but budget cuts may interfere with this effort.

\section{Lead Shot Surface Decontamination} Demonstration Project.--The INEL established a no-cost contract with CORPEX, a private contractor, to demonstrate their proprietary chemical for surface decontamination of lead shot. This work will be performed under agreement with Idaho State University, Pocatello, Idaho.

\section{Alternative-Fueled Vehicle Program}

\begin{abstract}
Regulations from the Clean Air Act and Executive Orders address specific requirements for 1995-98 with respect to ensuring efficient and effective fleet operations at DOE facilities. These requirements include a reduction in gasoline and diesel fuel consumption and transition to alternate-fueled vehicles.
\end{abstract}

In April 1994, DOE-ID approved the trade-in of surplus buses and expenditure of funds to obtain two buses to be fueled by liquefied natural gas.

In August 1994, funds were received to start the Alternate Fueled Vehicle Fleet Conversion program which will convert about 25 existing fleet vehicles from gasoline or diesel to using other fuels such as liquid petroleum gas, liquid natural gas, or compressed natural gas. A contract to convert light duty vehicles to natural gas was awarded to Turbo and Carburetion Systems of Minnesota.
Conversion work is now in progress. These vehicles will be bi-fuel vehicles--able to operate on either natual gas or gasoline. A contract to construct the first liquid natural gas and compressed natural gas fueling station at CFA was awarded to Drexes LNG/CNG Systems of Dallas, Texas in November 1994. The fueling station will be constructed during 1995.

In October 1994, a Cooperative Research and Development Agreement was established between the INEL and Detroit Diesel Corporation. The Corporation will furnish state-of-the-art experimental engines, and the INEL will test these prototype engines using liquid natural gas as fuel in an experimental group and diesel fuel in a control group.

\section{Waste Isolation Pilot Plant (WIPP) Support}

Management of transuranic waste is an important element of the INEL Waste Management Program. This includes supporting the Waste Isolation Pilot Plant (WIPP) near Carlsbad, New Mexico, anticipated to be the disposal site for most transuranic waste.

In 1991, ANL-W began their WIPP Waste Characterization of transuranic and alpha-low-level mixed wastes. Over 130,000 containers, retrievably stored at the RWMC, need to be characterized. Seventy-five 55gallon drums of debris waste have been characterized in the Hot Fuel Examination Facility at ANL-W to date. The waste characterization area inside that facility has recently been modified, and it is now expected that 90 drums/year can be characterized. Waste characterization data is required to do performance assessment modeling, which is necessary to get WIPP open as a permanent disposal facility. 
Scheduled to begin at ANL-W in 1995, the WIPP Gas Generation Experiments will examine gas generation caused by the decomposition of cellulosic waste, corrosion of metals, and radiolysis of water and waste that might impact performance of the salt beds at the WIPP waste repository. Also planned for treating wastes of the type to be stored at WIPP, is the Plasma Hearth Process Project, a high temperature thermal treatment that could be used to convert a variety of radioactive and mixed wastes into a stable, nonleaching, vitrified waste form. A bench-scale demonstration of the process will be conducted in the ANL-W Transient Reactor Test facility. Successful testing of the bench-scale unit will be followed by demonstration of a full-scale plasma hearth process unit.

\section{Buried Waste Integrated Demonstration Program}

A Technology Exposition was held in August 1994 in Idaho Falls. Technical sessions, exhibits, and tours were well attended by representatives from industry, DOE-Headquarters, and other government agencies. The presentations allowed 12 development teams with different Buried Waste Integrated Demonstration projects to give attendees details of the programs' technologies, to encourage partnerships and to resent business opportunities using these technologies.

INEL's Buried Waste Integrated Demonstration Program, which became a portion of the Landfill Stabilization Focus Area in early 1995, will participate in a demonstration of innovative technologies that may be used to reduce the estimated cost of remediation of chemical disposal pits and glass holes on the Brookhaven National Laboratory site. The INEL program assumed the lead for the Landfill Stabilization Focus Area in planning and implementing the demonstration. Most of the technologies proposed for demonstration are from the INEL program, but some from other DOE-Headquarters Office of Technology Development Programs will also be included.

In November 1994, the Buried Waste Integrated Demonstration Project hosted a Risk Management Roundtable in Idaho Falls. The session was attended by INEL employees, people from the private sector, members of the panel, and the moderator. A hypothetical scenario was enacted in which panelists played the roles of different stakeholders in a high desert region near a federal site. The discussion was filmed to be shown on Public Television in 1995.

Commercialization Action Plans were developed for 20 Buried Waste Integrated Demonstration technologies in 1994. One of these, the Rapid Geophysical Surveyor, was transferred via a license agreement to Sage Earth Science of Idaho Falls. Discussions toward a transfer agreement for the Rapid Transuranic Monitoring Laboratory also began in 1994. This unit, which provides analyses of samples containing transuranic materials in a short period of time, was subsequently transferred via a license agreement and a property loan to Thermo Analytical, a subsidiary of Thermo Electron. Additionally, the Contamination Control Unit, developed for rapid response to controlling releases of contamination, was transferred to the LITCO staff for emergency response at the RWMC.

\section{Privatization Activities}

In February 1993, a privatization effort was initiated for cleaning and decontaminating radioactively-contaminated laundry and respirators from INEL facilities. Continued 
operation of the INEL Central Laundry and Respirator Facility at CFA had become uneconomical when compared to the cost of purchasing commercial laundry and respirator services from the private sector. The subcontract for these services extending from fiscal year 1993 through 1995 was awarded to Interstate Nuclear Services of Richland, Washington.

In March 1993, the INEL issued a Request for Proposal for transportation and treatment services for the backlogged lowlevel waste at the Waste Experimental Reduction Facility (WERF) facility. The objective of the project was to process waste accumulated as a result of the WERF shutdown to reduce low-level waste storage at the INEL. The waste treatment was to provide a cost-effective means of maximum volume reduction of treated waste volume prior to disposal at the INEL. By using offsite services for low-level waste transportation and treatment, the INEL had the opportunity to make WERF operational for treatment of other wastes, such as mixed wastes. A twoyear subcontract was awarded to Scientific Ecology Group of Oak Ridge, Tennessee in June 1994. Shipment and treatment of a total of $99,700 \mathrm{ft}^{3}$ of incinerable low-level waste was completed by the end of December 1994. Another campaign for shipment and treatment began in early 1995 . Additional campaigns will depend on the WERF operational status and funding availability.

\subsection{ENVIRONMENTAL MONITORING}

\section{General}

During normal operation of the facilities at the INEL, some materials (both radioactive and nonradioactive) are released into the environment. Potential pathways by which such materials could be transported from the INEL to nearby populations are shown in Figure 3.1.

To evaluate these exposure pathways, and to verify compliance with applicable environmental protection laws and regulations, DOE Order 5400.1 requires an environmental monitoring program. Environmental monitoring consists of two separate activities: effluent monitoring and environmental surveillance. Effluent monitoring is the measurement of the waste stream prior to its release to the environment. Environmental surveillance is the measurement for the presence or absence and the concentrations (or the extent) of pollutants in the environment. Further defined by the DOE:

- Effluent monitoring is the collection and analysis of samples, or measurements of liquid and gaseous effluents for the purpose of characterizing and quantifying contaminants, assessing radiation exposures of members of the public, providing a means to control effluents at or near the point of discharge, and demonstrating compliance with applicable standards and regulations.

- Environmental surveillance is the collection and analysis of samples, or direct measurements, of air, water, soil, foodstuff, biota, and other media from DOE sites and their environs for the purpose of determining compliance with applicable standards and permit requirements, assessing radiation exposures of members of the public and assessing the effects, if any, on the local environment ${ }^{\mathrm{a}}$.

\footnotetext{
"DOE Order 5400.1, November 9, 1988, p. 8
} 


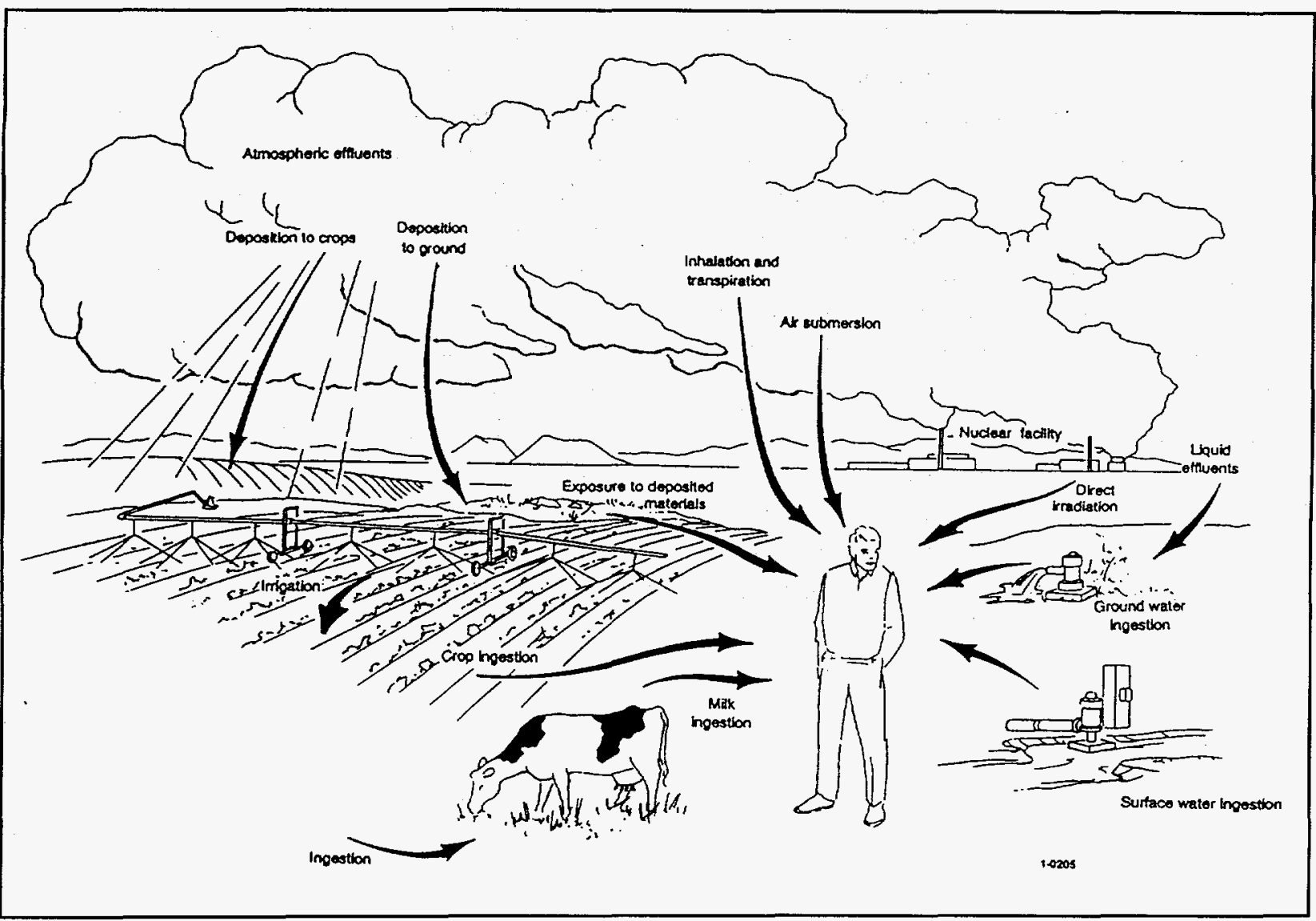

Figure 3.1 Potential Pathways from the INEL to Humans

\section{Organization of Monitoring in 1994}

Prior to 1994, the overall environmental surveillance program for the INEL was conducted by a division of DOE-ID, the Radiological and Environmental Sciences Laboratory (RESL). In 1993, the Department of Energy decided to transfer its environmental surveillance functions from the federal to the private sector. The majority of the onsite portion of the DOE program was transfered to EG\&G Idaho (and later LITCO) effective January 4, 1994 (Table 3.1). EG\&G used the Radiological Measurements Laboratory at TRA and Westinghouse Idaho Nuclear Company laboratories at ICPP and the INEL Research Center for radiological analyses in 1994.
The offsite environmental surveillance program was transferred to the Environmental Science and Research Foundation, who assumed operation of the program on April 11, 1994 (Table 3.2). The Foundation also assumed responsibility for the environmental research programs formerly administered by RESL, and is active in increasing awareness of INEL environmental programs through public relations/education. The Foundation continued to use the DOE laboratory to perform radiological analyses in 1994 while the Foundation sought and qualified offsite laboratories.

The operating contractors at each INEL facility were responsible for monitoring the effluents (releases) from their facilities and for any ambient monitoring or surveillance 
performed within their facility fences. Results of these programs are reported annually by each organization. With the consolidation of INEL contractors late in 1994, surveillance programs formerly conducted by Babcock and Wilcox and Westinghouse Idaho Nuclear Company were in the process of being combined with EG\&G-run programs in the new LITCO organization at the end of the year.

Ground-water surveillance was conducted largely by the U.S. Geological Survey (USGS). A description of this program and a summary of data collected in 1994 are given in Chapter 5, Ground Water. A program summary is presented in Table 3.3.
Air pathways were characterized by the National Oceanic and Atmospheric Administration/Air Resources Laboratory (NOAA/ARL) using data from the INEL meteorological measuring network. These data were used in part to compute doses to members of the public (see Section 4.4).

In January 1994, the State of Idaho's INEL Oversight Program took over the independent verification program operated by Idaho State University since 1989 . The University continued to perfom radiological analyses for the State program. 
TABLE 3.1

EG\&G/LITCO ENVIRONMENTAL SURVELLANCE RADIOLOGICAL PROGRAM SUMMARY (1994)

\begin{tabular}{|c|c|c|c|c|}
\hline \multirow[b]{2}{*}{ Medium Sampled } & \multirow[b]{2}{*}{ Type of Analysis } & \multicolumn{2}{|c|}{ Number of Locations and Frequency } & \multirow{2}{*}{$\begin{array}{c}\text { Minimum } \\
\text { Detectable } \\
\text { Concentration }\end{array}$} \\
\hline & & Onsite & Offsite & \\
\hline Air (Low-Volume) & $\begin{array}{c}\text { Gross alpha } \\
\text { Gross beta } \\
\text { Specific gamma } \\
\mathrm{Pu} \\
\mathrm{Am} \\
{ }^{90} \mathrm{Sr} \\
\text { Particulate matter }\end{array}$ & $\begin{array}{l}12 \text { weekly } \\
12 \text { weekly } \\
12 \text { quarterly } \\
12 \text { quarterly } \\
12 \text { quarterly } \\
12 \text { quarterly } \\
12 \text { quarterly }\end{array}$ & $\begin{array}{l}4 \text { weekly } \\
4 \text { weekly } \\
4 \text { quarterly } \\
4 \text { quarterly } \\
4 \text { quarterly } \\
4 \text { quarterly } \\
4 \text { quarterly }\end{array}$ & $\begin{array}{r}3 \times 10^{-16} \mu \mathrm{Ci} / \mathrm{mL} \\
8 \times 10^{-15} \mu \mathrm{Ci} / \mathrm{mL} \\
1 \text { to } 10 \times 10^{-15} \mu \mathrm{Ci} / \mathrm{mL} \\
2 \times 10^{-18} \mu \mathrm{Ci} / \mathrm{mL} \\
2 \times 10^{-18} \mu \mathrm{Ci} / \mathrm{mL} \\
3.5 \times 10^{-17} \mu \mathrm{Ci} / \mathrm{mL} \\
10 \mu \mathrm{g} / \mathrm{m}^{3}\end{array}$ \\
\hline Air (High-Volume) & $\begin{array}{c}\text { Gross gamma } \\
\text { Specific gamma } \\
\end{array}$ & $\begin{array}{l}2 \text { daily } \\
2 \text { monthly } \\
\end{array}$ & ---- & 1 to $10 \times 10^{-16} \mu \mathrm{Ci} / \mathrm{mL}$ \\
\hline $\begin{array}{c}\text { Air (Tritium } \\
\text { Samplers) } \\
\end{array}$ & ${ }^{3} \mathrm{H}$ as $\mathrm{HTO}$ & 2 at 1 to 2 /quarter & ---- & $1 \times 10^{-11} \mu \mathrm{Ci} / \mathrm{mL}$ \\
\hline Drinking Water & $\begin{array}{l}\text { Gross alpha } \\
\text { Gross beta } \\
{ }^{3} \mathrm{H} \text { as HTO } \\
{ }^{90} \mathrm{Sr}\end{array}$ & $\begin{array}{r}26 \text { monthly } \\
26 \text { monthly } \\
26 \text { monthly } \\
2 \text { monthly }\end{array}$ & $\begin{array}{l}-\cdots \\
-\cdots-- \\
-\cdots-\end{array}$ & $\begin{array}{l}3 \times 10^{-9} \mu \mathrm{Ci} / \mathrm{mL} \\
4 \times 10^{-9} \mu \mathrm{Ci} / \mathrm{mL} \\
4 \times 10^{-7} \mu \mathrm{Ci} / \mathrm{mL} \\
5 \times 10^{-10} \mu \mathrm{Ci} / \mathrm{mL}\end{array}$ \\
\hline Soil & $\begin{array}{c}\text { Specific gamma } \\
\mathrm{Pu} \\
\mathrm{Am} \\
{ }^{90} \mathrm{Sr} \\
\end{array}$ & $\begin{array}{l}\text { Varies annually } \\
\text { Varies annually } \\
\text { Varies annually } \\
\text { Varies annually }\end{array}$ & $\begin{array}{l}\cdots-- \\
\cdots-- \\
\cdots-- \\
-\cdots\end{array}$ & $\begin{array}{ll}1 \times 10^{-7} & \mu \mathrm{Ci} / \mathrm{g} \\
3 \times 10^{-9} & \mu \mathrm{Ci} / \mathrm{g} \\
3 \times 10^{-9} & \mu \mathrm{Ci} / \mathrm{g} \\
6 \times 10^{-8} & \mu \mathrm{Ci} / \mathrm{g} \\
\end{array}$ \\
\hline $\begin{array}{c}\text { Direct Radiation } \\
\text { Exposure } \\
\text { (Thermoluminescent } \\
\text { Dosimeters) } \\
\end{array}$ & Ionizing Radiation & 135 semiannually & ----- & $5 \mathrm{mR}$ \\
\hline $\begin{array}{c}\text { Direct Radiation } \\
\text { Exposure (Radiation } \\
\text { Surveys) } \\
\end{array}$ & Gamma Radiation & Varies annually $^{c}$ & $-\cdots$ & $\mathrm{N} / \mathrm{A}$ \\
\hline \multicolumn{5}{|c|}{$\begin{array}{l}\text { Not applicable. } \\
\text { onsite soil sampling is performed each year at different onsite facilities on a rotating seven-year schedule, } \\
\text { surveys are performed each year at different onsite facilities on a rotating three-year schedule. }\end{array}$} \\
\hline
\end{tabular}




\begin{tabular}{|c|c|c|c|c|}
\hline \multicolumn{5}{|c|}{$\begin{array}{l}\text { TABLE } 3.2 \\
\text { FOUNDATION ENVIRONMENTAL SURVEILLANCE RADIOLOGICAL PROGRAM SUMMARY (1994) }\end{array}$} \\
\hline \multirow[b]{2}{*}{ Medium Sampled } & \multirow[b]{2}{*}{ Type of Analysis } & \multicolumn{2}{|c|}{ Number of Locations and Frequency } & \multirow{2}{*}{$\begin{array}{l}\text { Minimum } \\
\text { Detectable } \\
\text { Concentration }\end{array}$} \\
\hline & & Onsite & Offsite & \\
\hline Air (Low-Volume) & $\begin{array}{c}\text { Gross alpha } \\
\text { Gross beta } \\
\text { Specific gamma } \\
\mathrm{Pu} \\
\mathrm{Am} \\
{ }^{90} \mathrm{Sr} \\
\text { Particulate matter }\end{array}$ & $\begin{array}{l}2 \text { weekly } \\
3 \text { weekly } \\
3 \text { quarterly } \\
1-2 \text { quarterly } \\
1-2 \text { quarterly } \\
1-2 \text { quarterly } \\
3 \text { quarterly }\end{array}$ & $\begin{array}{c}4 \text { weekly } \\
11 \text { weekly } \\
11 \text { quarterly } \\
4 \text { quarterly } \\
4 \text { quarterly } \\
4 \text { quarterly } \\
11 \text { quarterly }\end{array}$ & $\begin{array}{r}3 \times 10^{-16} \mu \mathrm{Ci} / \mathrm{mL} \\
8 \times 10^{-15} \mu \mathrm{Ci} / \mathrm{mL} \\
1 \text { to } 10 \times 10^{-15} \mu \mathrm{Ci} / \mathrm{mL} \\
6 \times 10^{-18} \mu \mathrm{Ci} / \mathrm{mL} \\
8 \times 10^{-18} \mu \mathrm{Ci} / \mathrm{mL} \\
1 \times 10^{-16} \mu \mathrm{Ci} / \mathrm{mL} \\
10 \mu \mathrm{g} / \mathrm{m}^{3}\end{array}$ \\
\hline $\begin{array}{l}\text { Air (Tritium } \\
\text { Samplers) }\end{array}$ & ${ }^{3} \mathrm{H}$ as HTO & None & 2 to $4 /$ quarter & $1 \times 10^{-11} \mu \mathrm{Ci} / \mathrm{mL}$ \\
\hline Air (Precipitation) & ${ }^{3} \mathrm{H}$ as $\mathrm{HTO}$ & 1 weekly/ 1 monthly & 1 monthly & $4 \times 10^{-7} \mu \mathrm{Ci} / \mathrm{mL}$ \\
\hline Drinking Water & $\begin{array}{l}\text { Gross alpha } \\
\text { Gross beta } \\
{ }^{3} \mathrm{H} \text { as HTO }\end{array}$ & $\begin{array}{l}\text { None } \\
\text { None } \\
\text { None }\end{array}$ & $\begin{array}{l}13 \text { semiannually } \\
13 \text { semiannually } \\
13 \text { semiannually }\end{array}$ & $\begin{array}{l}3 \times 10^{-9} \mu \mathrm{Ci} / \mathrm{mL} \\
4 \times 10^{-9} \mu \mathrm{Ci} / \mathrm{mL} \\
4 \times 10^{-7} \mu \mathrm{Ci} / \mathrm{mL}\end{array}$ \\
\hline Surface Water & $\begin{array}{l}\text { Gross alpha } \\
\text { Gross beta } \\
{ }^{3} \mathrm{H} \text { as HTO }\end{array}$ & $\begin{array}{l}\text { None } \\
\text { None } \\
\text { None }\end{array}$ & $\begin{array}{l}6 \text { quarterly } \\
6 \text { quarterly } \\
6 \text { quarterly }\end{array}$ & $\begin{array}{l}3 \times 10^{-9} \mu \mathrm{Ci} / \mathrm{mL} \\
4 \times 10^{-9} \mu \mathrm{Ci} / \mathrm{mL} \\
4 \times 10^{-7} \mu \mathrm{Ci} / \mathrm{mL}\end{array}$ \\
\hline $\begin{array}{l}\text { Animal Tissue } \\
\text { (Sheep) }^{\text {b }}\end{array}$ & Specific gamma & 4 annually & 2 annually & $7 \times 10^{-9} \mu \mathrm{Ci} / \mathrm{mL}$ \\
\hline $\begin{array}{c}\text { Animal Tissue } \\
\text { (Game) }\end{array}$ & Specific gamma & Varies annually ${ }^{\mathrm{c}}$ & $\overline{----}$ & $7 \times 10^{-9} \mu \mathrm{Ci} / \mathrm{mL}$ \\
\hline Foodstuffs (Milk) & $\begin{array}{c}{ }^{131} \mathrm{I} \\
{ }^{131} \mathrm{I} \\
{ }^{90} \mathrm{Sr} \\
{ }^{3} \mathrm{H} \text { as HTO } \\
{ }^{129} \mathrm{I} \\
\end{array}$ & $\begin{array}{l}\text { None } \\
\text { None } \\
\text { None } \\
\text { None } \\
\text { None }\end{array}$ & $\begin{array}{l}1 \text { weekly } \\
10 \text { monthly } \\
10 \text { annually } \\
10 \text { annually } \\
3 \text { annually }\end{array}$ & $\begin{array}{l}1 \times 10^{-9} \mu \mathrm{Ci} / \mathrm{mL} \\
1 \times 10^{-9} \mu \mathrm{Ci} / \mathrm{mL} \\
2 \times 10^{-9} \mu \mathrm{Ci} / \mathrm{mL} \\
4 \times 10^{-7} \mu \mathrm{Ci} / \mathrm{mL} \\
3 \times 10^{-10} \mu \mathrm{Ci} / \mathrm{mL}\end{array}$ \\
\hline Foodstuffs (Wheat) & $\begin{array}{l}\text { Specific gamma } \\
{ }^{90} \mathrm{Sr}\end{array}$ & $\begin{array}{l}\text { None } \\
\text { None }\end{array}$ & $\begin{array}{l}10 \text { annually } \\
10 \text { annually }\end{array}$ & $\begin{array}{l}4 \times 10^{-9} \mu \mathrm{Ci} / \mathrm{g} \\
4 \times 10^{-9} \mu \mathrm{Ci} / \mathrm{g}\end{array}$ \\
\hline Foodstuffs (Lettuce) & $\begin{array}{l}\text { Specific garnma } \\
{ }^{90} \mathrm{Sr}\end{array}$ & $\begin{array}{l}\text { None } \\
\text { None }\end{array}$ & $\begin{array}{l}8 \text { annually } \\
8 \text { annually }\end{array}$ & $\begin{array}{ll}2 \times 10^{-7} & \mu \mathrm{Ci} / \mathrm{g} \\
8 \times 10^{-8} & \mu \mathrm{Ci} / \mathrm{g}\end{array}$ \\
\hline Soil & $\begin{array}{c}\text { Specific gamma } \\
\mathrm{Pu} \\
\mathrm{Am} \\
{ }^{90} \mathrm{Sr}\end{array}$ & $\begin{array}{l}\text { None } \\
\text { None } \\
\text { None } \\
\text { None }\end{array}$ & $\begin{array}{l}12 \text { biennially } \\
12 \text { biennially } \\
12 \text { biennially } \\
12 \text { biennially } \\
\end{array}$ & $\begin{array}{l}4 \times 10^{-8} \mu \mathrm{Ci} / g \\
2 \times 10^{-9} \mu \mathrm{Ci} / g \\
3 \times 10^{-9} \mu \mathrm{Ci} / g \\
9 \times 10^{-8} \mu \mathrm{Ci} / \mathrm{g}\end{array}$ \\
\hline $\begin{array}{c}\text { Direct Radiation } \\
\text { Exposure } \\
\text { (Thermoluminescent } \\
\text { Dosimeters) } \\
\end{array}$ & Ionizing Radiation & None & 13 semiannually & $5 \mathrm{mR}$ \\
\hline $\begin{array}{ll}\text { a } & \text { Not applicable. } \\
\text { "Onsite" animals gra } \\
\text { onsite and serve as c } \\
\text { Only road-killed gan } \\
\text { studies. }\end{array}$ & $\begin{array}{l}\text { ed onsite for at least } f \\
\text { ntrols. } \\
\text { animals are sampled }\end{array}$ & $\begin{array}{l}\text { weeks before being } \\
\text { site. No controls are }\end{array}$ & $\begin{array}{l}\text { ed. "Offsite" anin } \\
\text { rally collected exce }\end{array}$ & $\begin{array}{l}\text { s have never grazed } \\
\text { for specific ecological }\end{array}$ \\
\hline
\end{tabular}




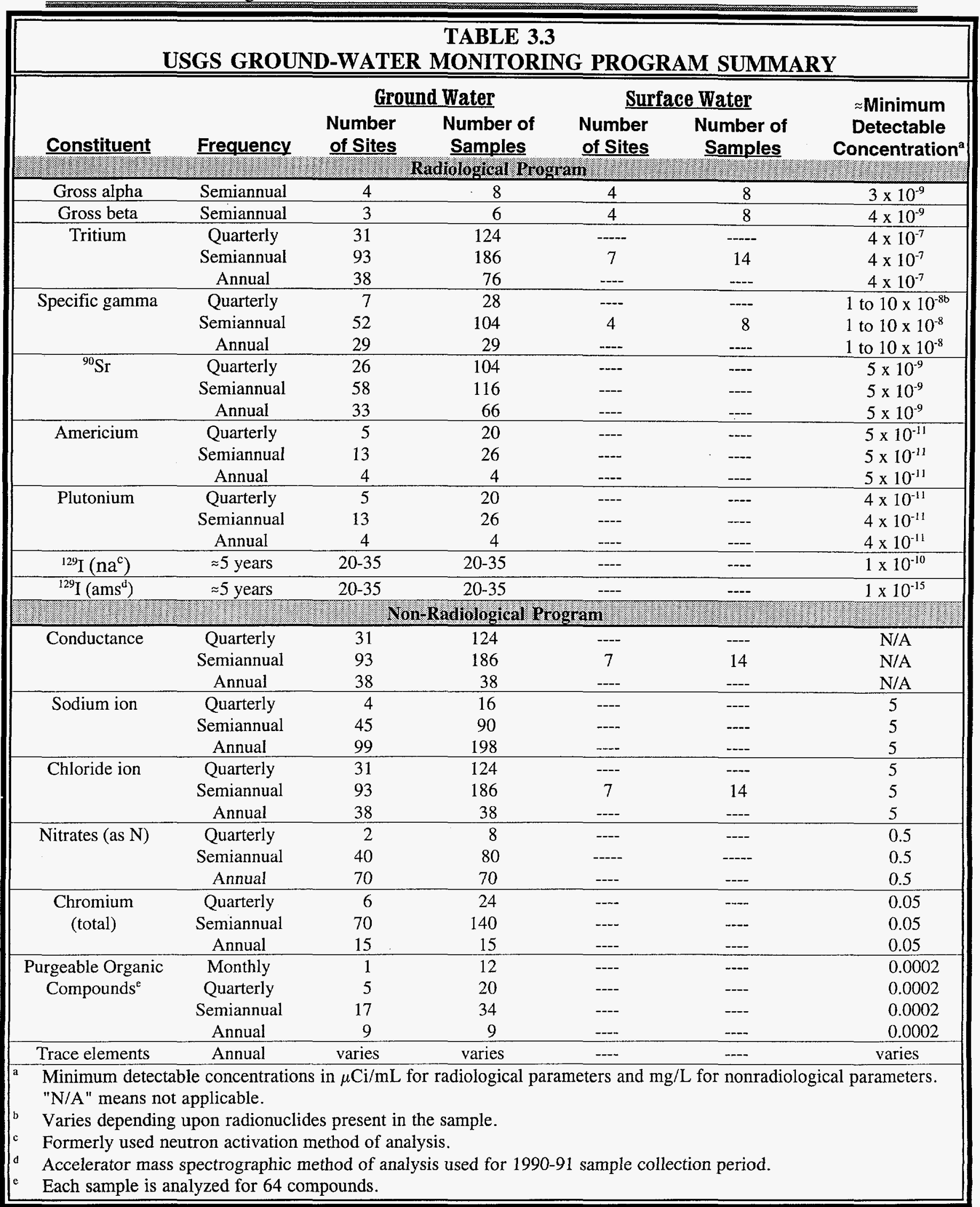





\section{ENVIRONMENTAL RADIOLOGICAL PROGRAM INFORMATION}

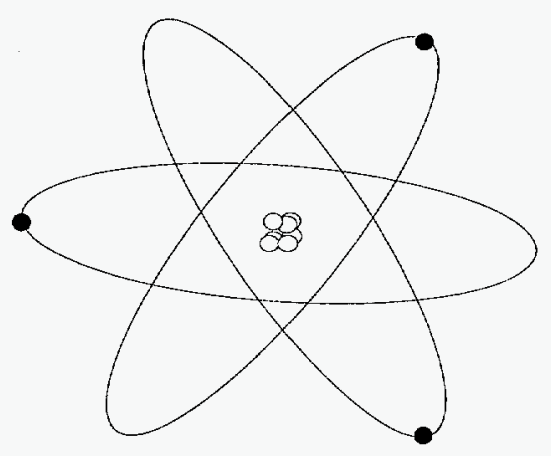




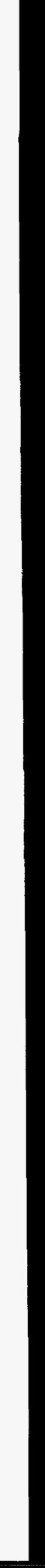




\title{
4. ENVIRONMENTAL RADIOLOGICAL PROGRAM INFORMATION
}

\begin{abstract}
In this chapter, individual analytical results for radiological data are presented with plus or minus $( \pm)$ two analytical standard deviations ( $2 \mathrm{~s}$ ), where all analytical uncertainties have been estimated, and " $\mathrm{s}$ " is an estimate of the population standard deviation " $\sigma$." Many of the results are less than or equal to $2 s$ (and, in fact, some were negative), which means that they are below the minimum detectable concentration.

If a result lies in the range of two to three times its estimated analytical uncertainty ( $2 \mathrm{~s}$ to $3 \mathrm{~s}$ ), and assuming that the result belongs to a Gaussian (normal) distribution, detection of radioactivity by the analysis may be questionable because of statistical variations within the group of samples. If the result exceeds $3 s$, there is confidence that radioactivity was detected (or, that the specific radionuclide was present in the sample). Further information may be found in Appendix B.

Unpaired, single-tailed t-tests were used to determine whether the annual means for the INEL or boundary stations were greater than the annual means for the distant stations. The statistical tests used a level of significance of $5 \%(\alpha=0.05)$. More information on statistical tests may be found in Appendix B.
\end{abstract}

\subsection{ENVIRONMENTAL SURVEILLANCE PROGRAM DESCRIPTION}

\section{High-Volume Air Samplers}

Two high-volume air samplers were operated at the Experimental Field Station (EFS) and Central Facilities Area (CFA). Both samplers pulled approximately 1,160 liters per minute (50 $\mathrm{ft}^{3}$ per minute) through a $10-\mathrm{cm}$ diameter polyester needled-felt filter. Filters were collected each workday and returned to the laboratory for counting.

The high-volume sampler filters were counted for 10 minutes in a sodium iodide well counter immediately following collection and again after approximately six hours and 24 hours. At the end of the third count, the net counts per minute were plotted on graph paper vs. hours after collection. Examination of the resulting decay curve characteristics allows staff to distinguish between the rapid decay of daughter products of ${ }^{222} \mathrm{Rn}\left({ }^{214} \mathrm{~Pb}\right.$ and $\left.{ }^{214} \mathrm{Bi}\right)$, the approximate 10.6 -hr effective half-life of ${ }^{220} \mathrm{Rn}$ daughters $\left({ }^{212} \mathrm{~Pb},{ }^{212} \mathrm{Bi}\right.$ and $\left.{ }^{208} \mathrm{Tl}\right)$, all of which are natural radionuclides, and the generally long half-life (compared to 10.6 hours) of any fission-products mixture. Data from these samplers provide timely information in the event of an INEL release. If the graph indicates the possible presence of activity from other than natural sources, the filter can then be submitted for specific gamma-emitting nuclide analysis on the High-Purity Germanium system.

\section{Low-Volume Air Samplers}

Airborne particulate radioactivity was monitored continuously by a network of lowvolume air samplers. The Foundation operated 11 air samplers outside the INEL boundaries, and 3 samplers on the INEL from April to the end of the year (Figure 4.1). EG\&G/LITCO collected air at 12 locations onsite and, from July through December, at 4 offsite locations. Locations of onsite samplers were selected to give adequate coverage in the event of facility releases of radioactivity. Seven offsite air samplers were located near the INEL boundary and four samplers were located at the distant communities of Blackfoot, Idaho Falls, Rexburg, and Craters of the Moon National Monument. Distant locations were used to 


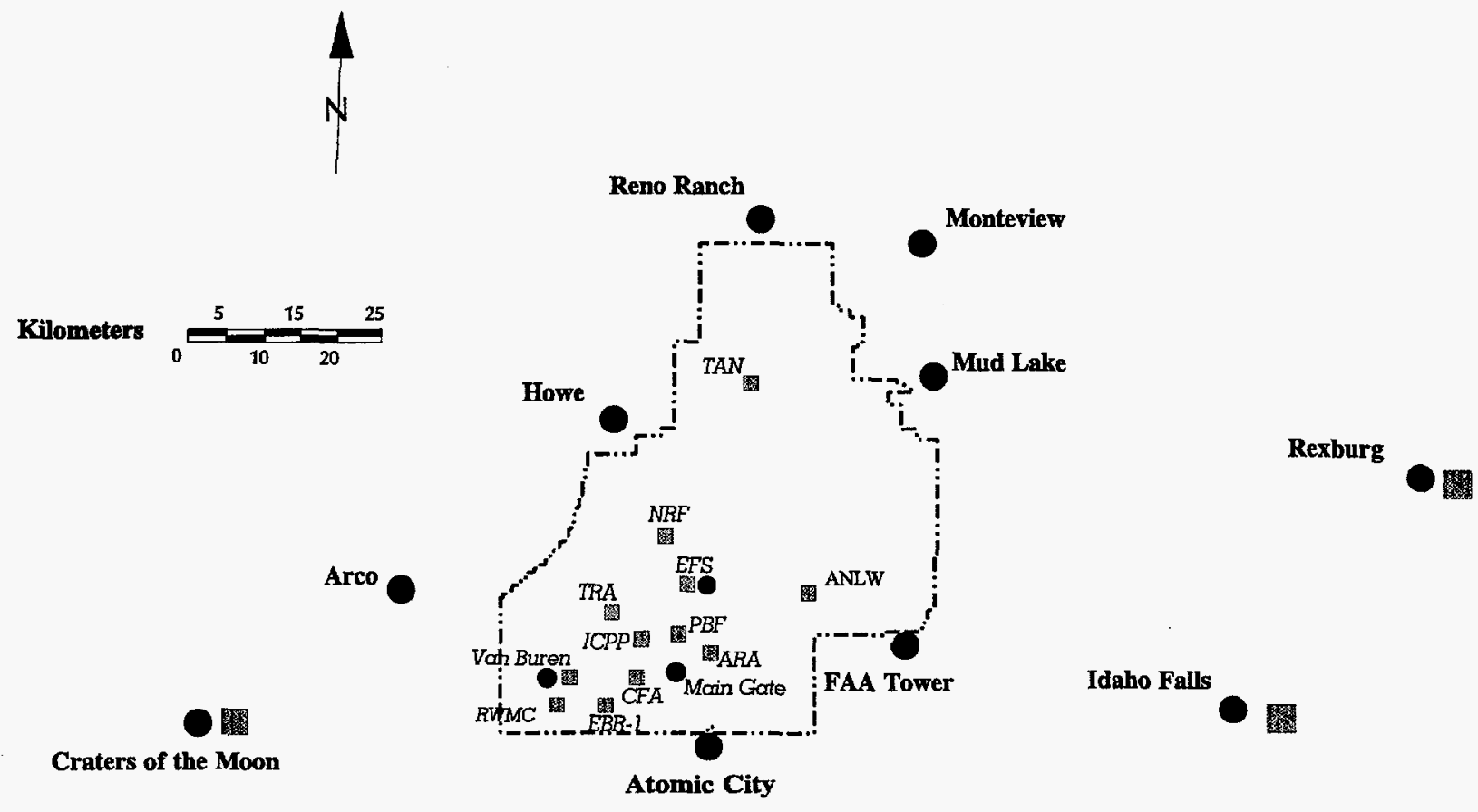

Blackfoot

1)

- Foundation Low Volume Air Sampler Location

踩 - EG\&G/LITCO Low Volume Air Sampler Location

Figure 4.1 Low-volume Air Sampler Locations

provide background measurements for comparison with data from boundary or onsite samplers that might be affected by INEL operations. The whole network provides comprehensive surveillance of particulate atmospheric radioactivity and makes it possible to differentiate INEL releases from worldwide fallout and long-lived natural radioactivity.
Each low-volume air sampler maintained an average air flow of about 50 liters per minute $\left(2 \mathrm{ft}^{3}\right.$ per minute) through a set of filters consisting of a 1.2 micrometer pore membrane filter followed by a charcoal cartridge filter. The filters are $99 \%$ efficient for airborne particulate radioactivity and airborne iodides. 


\section{Low-volume Filter Analyses}

The particulate filters from the lowvolume air samplers were collected weekly. For the Foundation (primarily offsite samples), the charcoal cartridges were screened for gross (or nonspecific) gamma activity weekly with a large well-type thallium-activated sodium iodide detector. The filters were counted either individually or as a stack of four filters. The counting efficiency was experimentally derived by the RESL analytical laboratory specifically for this ${ }^{131} I$ screening procedure. Initially, all gross gamma activity observed (which includes natural radon daughter products) is attributed only to ${ }^{131} \mathrm{I}$; therefore, the screening result represents the maximum ${ }^{131} \mathrm{I}$ activity that can be present on the cartridge. A number of filters were also counted each week specifically for ${ }^{131} I$ by gamma spectrometry using a High-Purity Germanium detector to determine the ${ }^{131} \mathrm{I}$ component, if any.

For cartridges collected from samplers operated by EG\&G/LITCO (primarily onsite samples), all the charcoal cartridges were evaluated for ${ }^{131} \mathrm{I}$ by gamma spectrometry.

Particulate filters were analyzed after waiting a minimum of four days to allow the naturally occurring, short-lived radon and thoron daughters to decay. Analyses for gross alpha activity were performed on filters from Blackfoot, Craters of the Moon, Arco, Mud Lake, and at the EG\&G/LITCO onsite locations shown in Figure 4.1.

Analysis for gross beta activity was performed weekly on filters from all air sampling locations in low background beta counters.

\section{Specific Radionuclide Analyses}

Specific radionuclide analyses are more sensitive indicators than gross beta analyses of concentrations of manmade radionuclides in air. Therefore, the membrane filters of the lowvolume samplers were composited according to location at the end of each quarter, and all composites were analyzed for specific radionuclides by gamma spectrometry. Selected composites were then submitted for analyses for alpha-emitting radionuclides (plutonium and americium) or ${ }^{90} \mathrm{Sr}$ on a rotating schedule. The analyses for alpha-emitting nuclides used chemical separation techniques followed by alpha spectrometry; for ${ }^{90} \mathrm{Sr}$, the chemical separation was followed by beta counting. Because both of the follow-up analyses consume the entire sample, only one of the two types can be performed on a given composite.

\section{Atmospheric Tritium Samplers}

Samplers for tritium in water vapor in the atmosphere were located in Idaho Falls, Atomic City, and at the EFS and Van Buren locations on the INEL. In these samplers, air was passed through a column of silica gel at a rate of approximately 0.3 liters per minute $(0.65$ $\mathrm{ft}^{3}$ per hour). Water vapor in the air was adsorbed by the gel in the column; columns were changed when the gel had adsorbed sufficient moisture to obtain a sample. Tritium concentrations were then determined by liquid scintillation counting of the water extracted from the silica gel columns.

\section{Precipitation Samplers}

Monthly precipitation samples were collected on the INEL at CFA and at the offsite location of Idaho Falls. In addition, weekly samples were collected at EFS (when available). A portion of each precipitation sample was submitted for tritium analysis by liquid scintillation counting. 


\section{Water Sampling Program Description}

Water monitoring on the INEL included sampling of ground water and surface water inflow.

Onsite drinking water samples were collected monthly from production (drinking water) wells in use at active INEL facilities by the contractor responsible for each facility. The Environmental Science and Research Foundation collected semiannual drinking water samples from boundary and distant communities and the Snake River. In addition, quarterly drinking water and surface water samples were collected from the Magic Valley area (Figure 4.2). Each quarterly sample was collected simultaneously with the State of Idaho Oversight Program for comparison to their independent environmental surveillance program. The Foundation's data are compared to the State's data for these water samples in Chapter 7, Quality Assurance.

In addition to production well monitoring, the U. S. Geological Survey (USGS) conducted an extensive ground-water surveillance program on the INEL Site. A description of the USGS portion of the water surveillance program and maps showing locations of their sampling wells are included in Chapter 5, Ground Water.

\section{Water Sample Analyses}

Each water sample collected by EG\&G/LITCO and the Foundation was submitted for gross (nonspecific) analyses for alpha and beta-emitting radionuclides that might be present in the water. For gross alpha analysis, a portion of the sample was evaporated on a stainless steel planchet and counted with a scintillation counter system. For gross beta activity, a portion was evaporated and counted in a low-background beta counter. The minimum detectable concentrations for gross alpha and gross beta were approximately $3 \times 10^{-9}$ and $4 \times$ $10^{-9} \mu \mathrm{Ci} / \mathrm{mL}$, respectively, or about $10 \%$ and $4 \%$ of the DOE derived concentration guides for radiation protection of the public (see Appendix A). These minimum detectable concentrations are also $20 \%$ and $8 \%$, respectively, of maximum contaminant levels established by the EPA for gross alpha and gross beta in public drinking water systems.

Tritium analyses were performed on all of the drinking and surface water samples collected. ${ }^{90} \mathrm{Sr}$ analyses were performed each month on samples from drinking water wells in the ICPP area because the water quality at two of these wells has periodically been affected by the ${ }^{90} \mathrm{Sr}$ waste plume as determined by the USGS.

Concentrations of tritium were determined by using a liquid scintillation counter. Strontium-90 was separated from the sample chemically and, after an ingrowth period, its ${ }^{90} \mathrm{Y}$ decay product was separated chemically and counted in a low-background beta counter to determine the amount of ${ }^{90} \mathrm{Sr}$ initially present in the sample. The minimum detectable concentrations for tritium and ${ }^{90} \mathrm{Sr}$ are $4 \times 10^{-7}$ and $5 \times 10^{-10} \mu \mathrm{Ci} / \mathrm{mL}$, or about $0.02 \%$ and $0.05 \%$, respectively, of the DOE derived concentration guides for radiation protection of the public. These minimum detectable concentrations are about $2 \%$ and $6 \%$, respectively, of maximum contaminant levels for community drinking water listed by the EPA in 1994.

\section{Foodstuff Sampling Program}

General. Samples of milk, wheat, potatoes, and leafy garden lettuce from locations near the INEL boundary and at distant locations were collected (Figure 4.2). Tissues were also obtained from game animals killed on the 


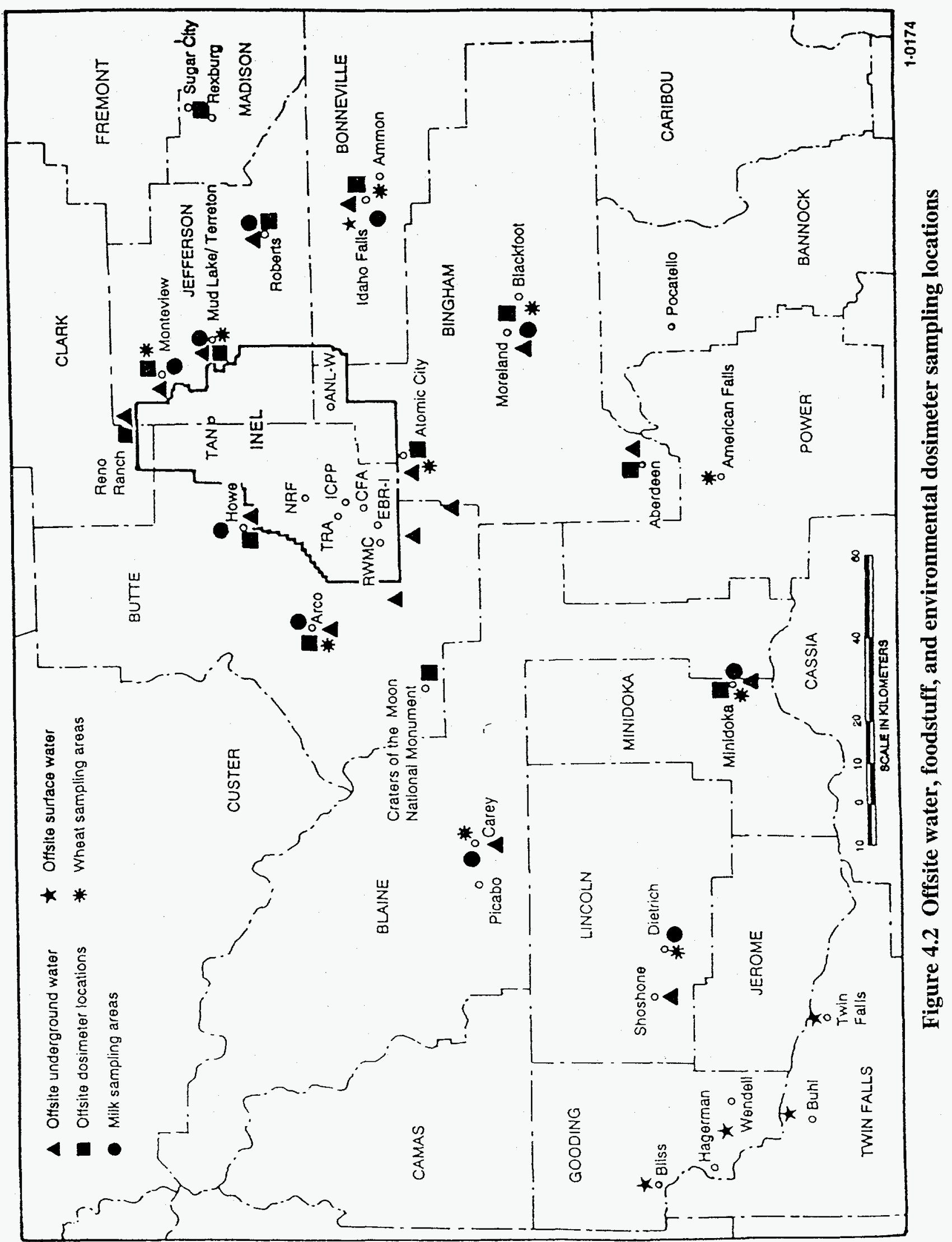


INEL. Wheat, potatoes, and lettuce were chosen for sampling because they are part of the typical American diet or are major agricultural products of the region and represent a potential pathway to the public for radionuclides from fallout or from INEL operations. Game animals represent a potential pathway to members of the public who might consume animals that have spent time on the INEL.

Milk. Milk samples were collected from both commercial and single-family dairies. A four-liter (one-gallon) sample was obtained from each location monthly, except in Idaho Falls where a sample was collected weekly. All milk samples were passed through an anion exchange resin, which was then analyzed for ${ }^{131} I$ by gamma spectrometry. Milk from each location was analyzed for ${ }^{90} \mathrm{Sr}$ and tritium once during the year.

Lettuce. Lettuce samples were obtained from private gardens in communities in the vicinity of the INEL. Samples were washed to remove any soil (as in normal food preparation), dried, reduced to a powdered form, and weighed. All lettuce samples were analyzed for ${ }^{90} \mathrm{Sr}$ and gamma-emitting radionuclides.

Wheat. Wheat samples were collected from grain elevators in the INEL vicinity (Figure 4.2). A portion of each sample was placed in a plastic container and weighed. All wheat samples were analyzed for ${ }^{90} \mathrm{Sr}$ and gamma-emitting radionuclides.

Potatoes. Potato samples were collected from storage warehouses in the INEL vicinity. The samples, with cleaned skins included, were processed and weighed. All potato samples were analyzed for ${ }^{90} \mathrm{Sr}$ and gamma-emitting radionuclides.
Sheep. Samples of tissue (muscle, liver, thyroid) were collected from sheep grazing on the INEL. Control samples were collected at Blackfoot. The muscle and liver were analyzed by gamma spectrometry; the thyroid was analyzed for ${ }^{131} \mathrm{I}$.

Game Animals. Selected tissues (muscle, liver, and thyroid) were collected from game animals killed on INEL roads. Thyroid samples were placed in vials and analyzed by gamma spectrometry. Muscle and liver samples were processed, placed in a plastic container, and weighed prior to gamma spectrometry.

\section{Soil Sampling Program}

To establish background levels of natural and fallout radioactivity in surface soil and to assess any potential buildup of radioactivity from INEL operations, soil samples were collected annually from distant and boundary locations from 1970-78 (except 1972 and 1977). The biennial soil sampling program was established in 1978 for offsite locations (Figure 4.3). During 1994, all offsite stations were sampled. A rotating seven-year schedule is used to sample onsite soils around major INEL facilities.

Soil samples collected in 1970, 1971, and 1973 represented a composite of five cores of soil from a $1-\mathrm{m}^{2}$ area. Each core was a cylinder $10 \mathrm{~cm}$ in diameter and $5 \mathrm{~cm}$ in depth. In all other years, the five cores were collected from a $100-\mathrm{m}^{2}$ area. A number of samples from the 5- to $10-\mathrm{cm}$ depth were also collected.

Concentrations of natural radioactivity in the surface soil were previously reported ${ }^{\mathrm{a}}$. The ${ }^{238} \mathrm{U}$ and ${ }^{232} \mathrm{Th}$ activities were determined from those of the progeny radionuclides, ${ }^{214} \mathrm{~Pb}$

a. U.S. Energy Research and Development Administration, Idaho Operations Office, 1976 Environmental Monitoring Report, IDO12082(76), May 1977, p. 27. 


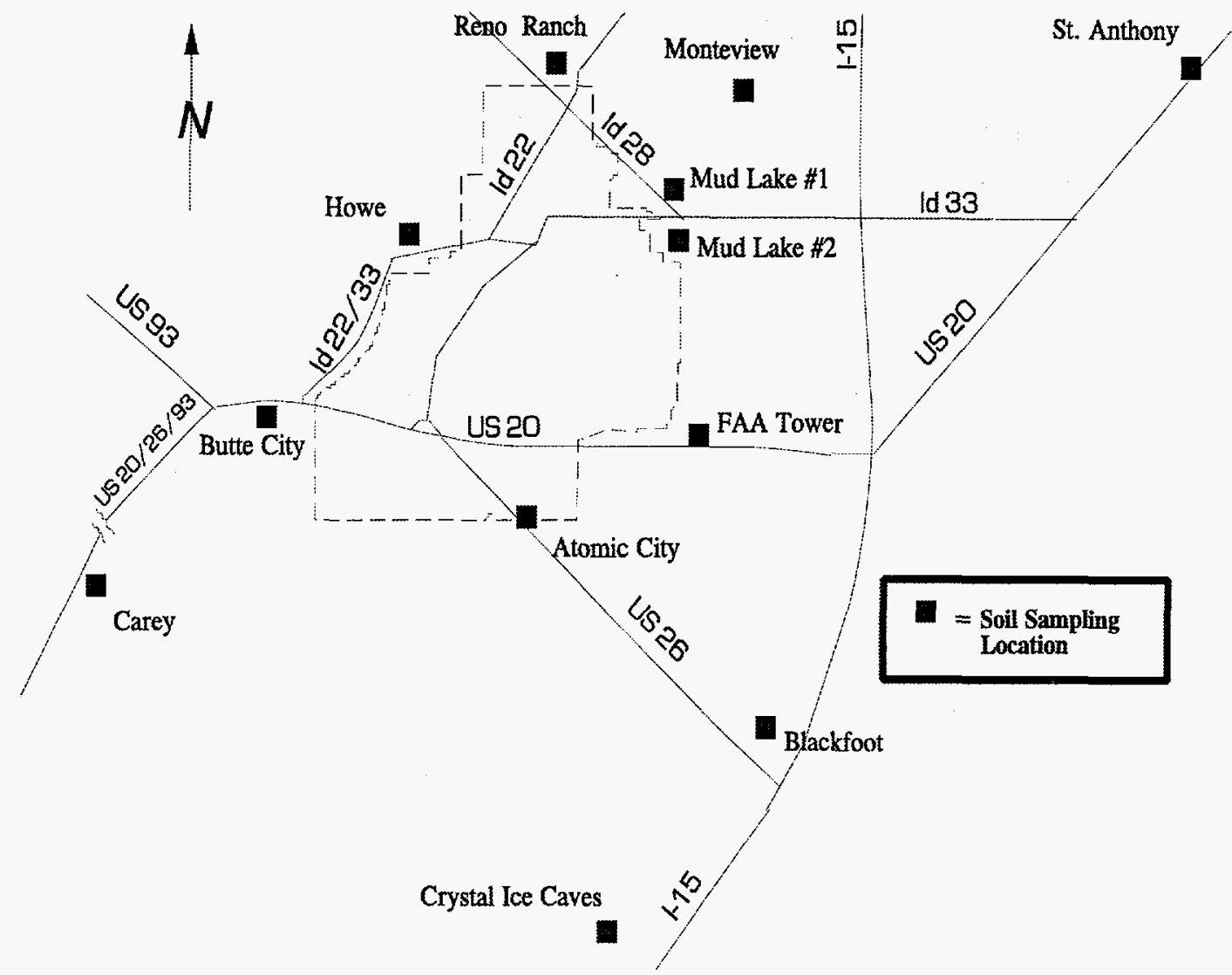

Figure 4.3 Offsite soil sampling locations

and ${ }^{228} \mathrm{Ac}$. Data indicates that the average concentrations of uranium, thorium, and ${ }^{40} \mathrm{~K}$ in the earth's upper crust, when translated from $\mathrm{ppm}$ to $\mathrm{pCi} / \mathrm{g}$ are $0.9,1.1$, and $17 \mathrm{pCi} / \mathrm{g}$, respectively. The local soils averaged about $1.5,1.3$ and $19 \mathrm{pCi} / \mathrm{g}$, respectively, values that are slightly higher in natural radioactivity than earth crustal averages. Although much of the surface rock on the Snake River Plain is basalt, the local soil is largely derived from silicic volcanics, which have higher uranium and thorium concentrations than basalt.

Estimates of the average external dose equivalent received by a member of the public from ${ }^{238} \mathrm{U}$ plus decay products, ${ }^{232} \mathrm{Th}$ plus decay products, and ${ }^{40} \mathrm{~K}$ in average area soil were

a. D. T. Oakley, Natural Radiation Exposures in the United States, U.S. Environmental Protection Agency, ORP/STD 72-1, 1972, p. 16. calculated to be 21,28 , and $27 \mathrm{mrem} / \mathrm{yr}$, respectively, for a total of $76 \mathrm{mrem} / \mathrm{yr}$. Because heavy snow cover can reduce the effective dose equivalent Idaho residents receive from the soil of the area, a correction must be made each year for snow cover (see Table 4.10).

The soils were dried at least three hours at about $120^{\circ} \mathrm{C}$ and sieved. Only soil particles less than 500 micrometers in diameter (35 mesh) were analyzed.

\section{Environmental Dosimeters}

Environmental dosimeters, known as thermoluminescent dosimeters (TLDs), were used to measure ionizing radiation exposures (beta energies greater than $200 \mathrm{keV}$ and gamma energies greater than $10 \mathrm{keV}$ ). The TLDs 
measure ionizing radiation exposures from natural radioactivity in the air and soil, cosmic radiation from outer space, fallout from nuclear weapons tests, radioactivity from fossil fuel burning, and radioactive effluents from INEL operations and other industrial processes.

At each location, a dosimeter card containing five individual chips was placed one meter above ground level. The dosimeter card at each location was changed semiannually. There were 7 distant community locations, 6 boundary locations (Figure 4.2), and 135 locations on the INEL.

\subsection{ENVIRONMENTAL SURVEILLANCE PROGRAM RESULTS}

\section{High-Volume Samplers}

Two onsite high-volume air monitors (located at CFA and EFS) continuously sample air for particulate airborne radioactivity. All routine analyses during 1994 indicated no measurable concentrations of manmade radionuclides. Beryllium-7, a naturally occurring radionuclide produced by the interaction of cosmic radiation and nitrogen in the atmosphere, was detected in all of the samples. During the second quarter, a special analysis was performed on the CFA air filter following a possible airborne ${ }^{181} \mathrm{Hf}$ release from TRA on April 4, 1994 . No ${ }^{181} \mathrm{Hf}$ or other manmade radionuclides were observed on the filter.

\section{Low-Volume Charcoal Cartridge ${ }^{131}$ I Analyses}

A total of over 1000 cartridges were analyzed specifically for ${ }^{131} \mathrm{I}$ during 1994 , including those analyzed by gamma spectro- metry following gross gamma screening. No detectable concentrations of ${ }^{131} \mathrm{I}$ were found in any of the charcoal cartridges analyzed.

\section{Low-volume Gross Alpha}

Gross alpha concentrations obtained by EG\&G/LITCO, both onsite and offsite, were significantly lower than those obtained by the Foundation at common locations (Table 4.1). This discrepancy is likely due to a difference in laboratory analytical techniques and instrumentation, or to the difference in elapsed time between filter collection and analysis. EG\&G/LITCO counted filters for gross alpha after waiting a longer time period than the Foundation. This may allow for greater decay of natural radioactivity. An investigation is currently being conducted into the effect of holding times on gross alpha concentrations.

Offsite and onsite concentrations of samples collected by the Foundation, however, were similar to historic values. Gross alpha concentrations are usually greater at the distant location of Blackfoot than at the other locations due to contributions from non-INEL sources. There was no statistical difference between the gross alpha concentrations for the onsite, boundary and distant stations in data collected by the Foundation.

\section{Low-Volume Gross Beta}

Analysis of gross beta concentrations in air samples collected by the Foundation and those collected by EG\&G/LITCO at common locations indicated that the Foundation results were, in general, statistically higher. See Chapter 7 for a comparison of gross beta concentrations. This difference is probably a result of differences in the analytical methods and instrumentation used in the counting of the filters. Due to this statistical difference, direct 


\begin{tabular}{|c|c|c|c|c|}
\hline \multicolumn{5}{|c|}{$\begin{array}{c}\text { TABLE 4.1 } \\
\text { GROSS ALPHA ACTIVITY IN AIR (1994) }\end{array}$} \\
\hline \multicolumn{5}{|c|}{ Environmental Science and Research Foundation Data } \\
\hline & & & \multicolumn{2}{|c|}{$\begin{array}{l}\text { Concentration } \\
\left(\times 10^{-15} \mu \mathrm{Ci} / \mathrm{mL}\right)\end{array}$} \\
\hline Group & Location & $\begin{array}{c}\text { Number of } \\
\text { Samples }\end{array}$ & $\begin{array}{l}\text { Range of } \\
\text { Samples }\end{array}$ & $\underline{A n n u a l ~ M e a n ~}^{\mathrm{a}}$ \\
\hline Distant & $\begin{array}{l}\text { Blackfoot } \\
\text { Craters of the Moon }\end{array}$ & $\begin{array}{l}52 \\
52\end{array}$ & $\begin{array}{l}0.8-3.9 \\
0.4-3.8 \\
\text { Grand } \text { Mean }^{a}\end{array}$ & $\begin{array}{l}2.0 \pm 0.2 \\
1.6 \pm 0.2 \\
1.8 \pm 0.2\end{array}$ \\
\hline Boundary & $\begin{array}{l}\text { Arco } \\
\text { Mud Lake }\end{array}$ & $\begin{array}{l}52 \\
40\end{array}$ & $\begin{array}{l}0.3-2.8 \\
0.4-3.6 \\
\text { Grand Mean }^{a}\end{array}$ & $\begin{array}{l}1.6 \pm 0.2 \\
1.7 \pm 0.3 \\
1.6 \pm 0.1\end{array}$ \\
\hline INEL & $\begin{array}{l}\text { EFS } \\
\text { Main Gate }\end{array}$ & $\begin{array}{l}39 \\
39\end{array}$ & $\begin{array}{l}0.7-4.0 \\
0.7-4.0 \\
\text { Grand } \text { Mean }^{a}\end{array}$ & $\begin{array}{l}1.8 \pm 0.3 \\
\frac{1.6 \pm 0.3}{1.8 \pm 0.2}\end{array}$ \\
\hline \multicolumn{5}{|c|}{ EG\&G/LITCO Data } \\
\hline & & & \multicolumn{2}{|c|}{$\begin{array}{l}\text { Concentration } \\
\left(\times 10^{-15} \mu \mathrm{Ci} / \mathrm{mL}\right)\end{array}$} \\
\hline Group & Location & $\begin{array}{c}\text { Number of } \\
\text { Samples }\end{array}$ & $\begin{array}{l}\text { Range of } \\
\text { Samples }\end{array}$ & Annual Mean $^{\mathrm{a}}$ \\
\hline Distant & $\begin{array}{l}\text { Blackfoot } \\
\text { Craters of the Moon } \\
\text { Idaho Falls } \\
\text { Rexburg }\end{array}$ & $\begin{array}{l}28 \\
28 \\
29 \\
25\end{array}$ & $\begin{array}{l}-1.4-1.7 \\
-2.1-3.1 \\
-1.7-3.0 \\
-2.0-3.0 \\
\text { Grand } \text { Mean }^{a}\end{array}$ & $\begin{array}{l}0.5 \pm 0.3 \\
0.2 \pm 0.4 \\
0.6 \pm 0.3 \\
0.5 \pm 0.5 \\
0.5 \pm 0.2\end{array}$ \\
\hline INEL & $\begin{array}{l}\text { ANL-W } \\
\text { ARA } \\
\text { CFA } \\
\text { EBR-1 } \\
\text { EFS } \\
\text { ICPP } \\
\text { NRF } \\
\text { PBF } \\
\text { RWMC } \\
\text { TAN } \\
\text { TRA } \\
\text { Van Buren }\end{array}$ & $\begin{array}{l}51 \\
51 \\
47 \\
52 \\
52 \\
52 \\
51 \\
45 \\
50 \\
52 \\
52 \\
52\end{array}$ & $\begin{array}{l}-3.1-5.0 \\
-3.3-2.5 \\
-2.0-11 \\
-3.4-5.5 \\
-3.0-5.3 \\
-2.5-3.6 \\
-3.2-20^{\mathrm{b}} \\
-4.0-7.0 \\
-1.5-3.0 \\
-3.7-7.0 \\
-2.3-5.2 \\
-4.0-6.0 \\
\text { Grand Mean }\end{array}$ & $\begin{array}{l}0.4 \pm 0.3 \\
0.2 \pm 0.3 \\
0.7 \pm 0.7 \\
0.7 \pm 0.5 \\
0.5 \pm 0.4 \\
0.0 \pm 0.3 \\
0.7 \pm 0.9 \\
0.2 \pm 0.5 \\
0.4 \pm 0.3 \\
0.2 \pm 0.4 \\
0.1 \pm 0.4 \\
\underline{0.2 \pm 0.5} \\
0.4 \pm 0.1\end{array}$ \\
\hline
\end{tabular}


comparisons are made in the following sections only between sets of data collected by a single organization.

Weekly gross beta concentrations in air samples collected by the Foundation ranged from a low of $(4 \pm 3) \times 10^{-15} \mu \mathrm{Ci} / \mathrm{mL}$ at Van Buren during the month of October to a high of $(69 \pm 16) \times 10^{-15} \mu \mathrm{Ci} / \mathrm{mL}$ at Mud Lake during January. EG\&G/LITCO results ranged from $(0 \pm 3) \times 10^{-15} \mu \mathrm{Ci} / \mathrm{mL}$ at CFA during the month of July to a high of $(60 \pm 10) \times 10^{-15} \mu \mathrm{Ci} / \mathrm{mL}$ at EFS during March. Figure 4.4 indicates the average weekly gross beta concentrations for the INEL, boundary, and distant station groups.
These data are typical of the annual pattern for gross beta concentrations in air, with higher values generally occurring at the beginning and end of the year during wintertime inversion conditions. While it is difficult to track any one of the five individual groups of stations in Figure 4.4, the variations of the five groups generally correlate very well, indicating the fluctuations are real and not an artifact of the analysis.

Statistical comparisons were made between monthly mean gross beta concentrations at each individual location and the distant group mean gross beta concentration.

\section{Weekly Gross Beta Concentrations in Air}

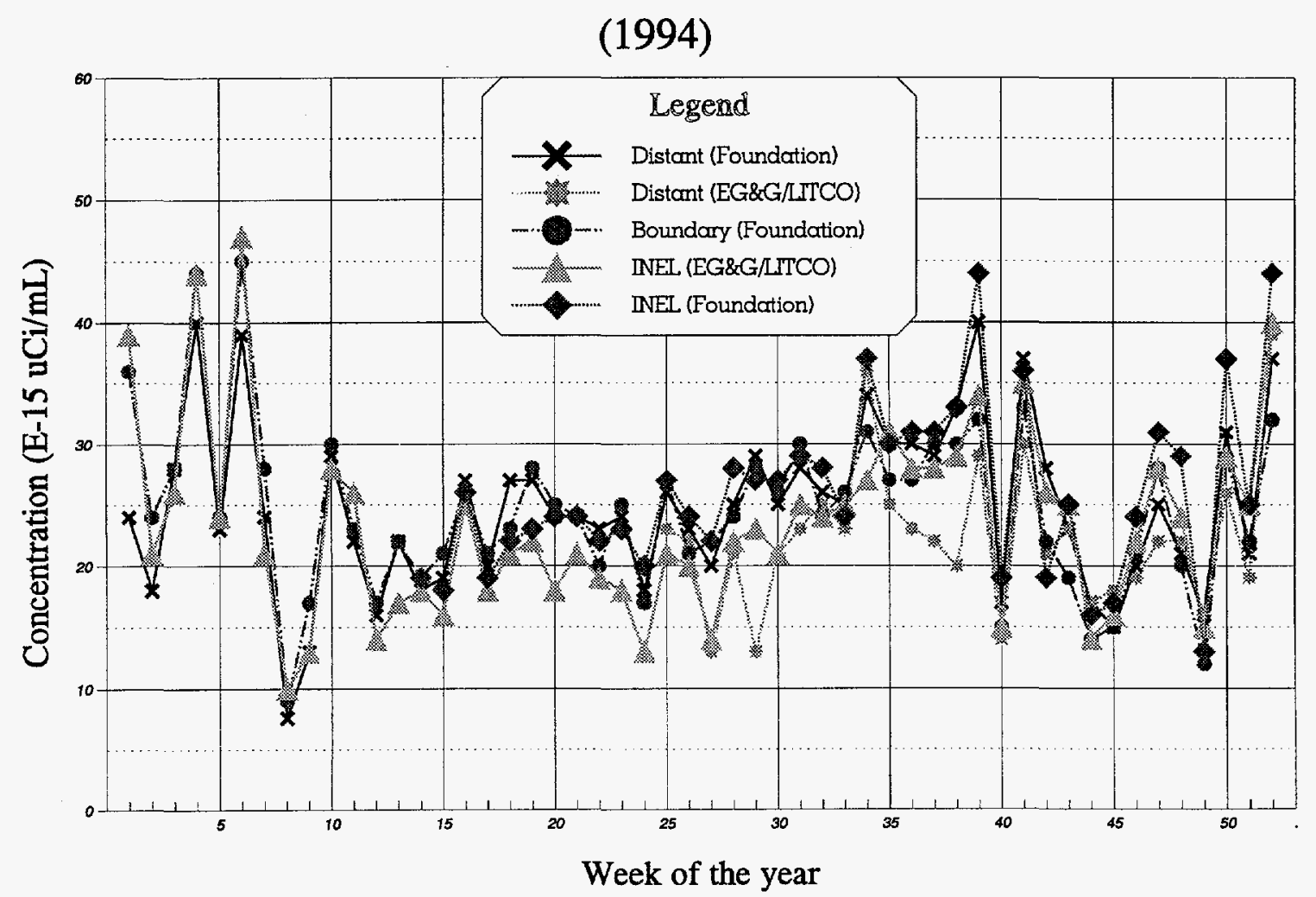

Figure 4.4 Weekly Gross Beta Concentrations in Air (1994) 
Statistical differences were noted in 8 of 84 (10\%) comparisons involving boundary locations and 18 of 99 (18\%) comparisons involving onsite locations (Table 4.2). Statistical comparisons were also made between the mean gross beta concentration of the boundary group (or onsite group) and the distant group mean gross beta concentration. The boundary group was found to be statistically higher in the month of January.

\begin{tabular}{|c|c|c|c|c|c|c|c|c|c|c|c|c|c|}
\hline \multicolumn{14}{|c|}{$\begin{array}{c}\text { TABLE } 4.2 \\
\text { GROSS BETA STATISTICAL COMPARISON TABLE (1994) }\end{array}$} \\
\hline \multicolumn{14}{|c|}{ Environmental Science and Research Foundation Data } \\
\hline Location & Jan & Feb & Mar & Apr & May & Jun & Jul & Aug & Sep & Oct & Nov & Dec & Year $^{b}$ \\
\hline \multicolumn{14}{|l|}{ Arco } \\
\hline \multicolumn{14}{|l|}{ Atomic City } \\
\hline \multicolumn{14}{|l|}{ FAA Tower } \\
\hline \multicolumn{14}{|l|}{ Howe } \\
\hline \multicolumn{14}{|l|}{ Monteview } \\
\hline \multirow{2}{*}{\multicolumn{14}{|c|}{$\begin{array}{l}\text { Mud Lake } \\
\text { Reno Ranch }\end{array}$}} \\
\hline & & & & & & & & & & & & & \\
\hline \multicolumn{14}{|c|}{ Boundary Group } \\
\hline \multicolumn{14}{|c|}{ EFS } \\
\hline \multirow{2}{*}{\multicolumn{14}{|c|}{$\begin{array}{l}\text { Main Gate } \\
\text { Van Buren }\end{array}$}} \\
\hline & & & & & & & & & & & \multicolumn{2}{|c|}{ Van Buren } & \\
\hline \multirow{2}{*}{\multicolumn{14}{|c|}{ EG\&G/LITCO Data }} \\
\hline & & & & & & & & & & & & & \\
\hline Location & Jan & Feb & Mar & Apr & May & Jun & Jul & Aug & Sep & Oct & Nov & Dec & Year $^{b}$ \\
\hline \multicolumn{14}{|l|}{ ANL-W } \\
\hline \multicolumn{14}{|l|}{ ARA } \\
\hline \multicolumn{14}{|l|}{ CFA } \\
\hline \multicolumn{14}{|l|}{ EBR-1 } \\
\hline \multicolumn{14}{|l|}{ EFS } \\
\hline \multicolumn{14}{|l|}{ ICPP } \\
\hline \multicolumn{14}{|l|}{ NRF } \\
\hline \multicolumn{14}{|l|}{ PBF } \\
\hline \multicolumn{14}{|l|}{ RWMC } \\
\hline \multicolumn{14}{|l|}{ TAN } \\
\hline \multicolumn{14}{|l|}{ TRA } \\
\hline \multicolumn{14}{|c|}{ Van Buren } \\
\hline INEL Grot & & & & & & 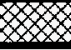 & & & & & & & \\
\hline $\begin{array}{ll}\text { a A black bl } \\
\text { statistically } \\
\text { Cross-hatc } \\
\text { yet deploy } \\
\text { established } \\
\text { b Annual co }\end{array}$ & $\begin{array}{l}n \text { the } \\
\text { ater } t \text { l } \\
\text { areas }\end{array}$ & istical & for & $\begin{array}{l}\text { that } \\
\text { oss b } \\
\text { data } \\
\text { Foun } \\
\text { I was } \\
\text { e tim }\end{array}$ & $\begin{array}{l}\text { me } \\
\text { mpar }\end{array}$ & $\begin{array}{l}\text { ed, } \\
\text { whe }\end{array}$ & $\begin{array}{l}\text { for } t \\
\text { e pos } \\
\text { dist } \\
\text { gle-ta } \\
\text { lirect }\end{array}$ & $\begin{array}{l}\text { ble be } \\
\text { stati } \\
\text { ta }-\mathrm{t} \\
\text { co }\end{array}$ & & $\begin{array}{l}\text { that } \\
\text { for } t \\
\text { her a } \\
\text { k } / \mathrm{L} \\
.05 \text { ). } \\
\text { is we }\end{array}$ & a) & $\begin{array}{l}\text { was } \\
\text { time } \\
\text { rs we } \\
\text { ere no } \\
\text { ole. }\end{array}$ & $\begin{array}{l}\text { eriod. } \\
\text { e not } \\
\text { yet }\end{array}$ \\
\hline
\end{tabular}


Foundation data indicated the onsite group was statistically higher than the distant group in November; EG\&G/LITCO data showed a statistical difference in September.

Statistical comparisons were made between annual gross beta mean concentrations at individual locations and the mean background gross beta concentration (Table 4.2). No statistical differences were found offsite. The gross beta concentration at EFS was statistically greater than the distant gross beta concentration obtained by the Foundation. EG\&G/LITCO data indicated statistical differences at seven INEL locations and the INEL group as a whole.

Monthly gross beta concentrations for the distant, boundary, and INEL groups are shown in Figure 4.5. Gross beta concentrations peaked dramatically after the Chernobyl accident in April 1986. The distant location vs. INEL graph also shows the effects of ${ }^{125} \mathrm{Sb}$ releases from the Fluorinel Dissolution and Fuel Storage Facility at ICPP during late 1986 to mid-1988.

Annual mean gross beta concentrations ranged from $20 \times 10^{-15} \mu \mathrm{Ci} / \mathrm{mL}$ at RWMC to 27 $x 10^{-15} \mu \mathrm{Ci} / \mathrm{mL}$ at EBR-1 and NRF (Table 4.3). These concentrations are $0.7 \%$ and $0.9 \%$ of the annual derived concentration guide for gross beta, respectively.

Gross beta concentrations can vary widely from location to location as a result of a number of factors such as diverse local soil and meteorological conditions. When statistical differences like these are found, the results of specific nuclide analyses (discussed in the following section) are examined to try to pinpoint a possible INEL cause for the differences. While most specific radionuclides that were found were only slightly above the minimum detectable concentration, one $\left({ }^{90} \mathrm{Sr}\right)$ appeared significantly above the minimum detectable concentration in the first and third quarters. The higher number of statistical differences seen onsite vs. offsite, the consistent statistical differences seen at Mud Lake (the location with the highest expected offsite concentrations as described in Section 4.4), and the presence of ${ }^{90} \mathrm{Sr}$ at both onsite and offsite locations may indicate a possible INEL origin for at least some of the statistical differences. This could not be correlated to any specific facility or release event.

\section{Low-Volume Specific Radionuclides}

Besides ${ }^{7} \mathrm{Be}$, which is naturally occurring and appears in all the quarterly composites analyzed, several other radionuclides were observed (Table 4.4). Most results were just above the minimum detectable concentration, and appeared throughout the year, with most occurring during the first quarter. As described earlier, INEL releases may have been the source of at least some of the detectable radioactivity, but no specific source could be identified.

Plutonium-238 detected at ICPP during the third and fourth quarters may be the result of suspension of soil from the vicinity of the air sampler. A construction project was in progress close to the air sampler during this time period. Soils nearby are known from historical sampling data to contain slightly elevated concentrations of ${ }^{238} \mathrm{Pu}$.

\section{Atmospheric Tritium}

A total of 17 samples (nine by the Foundation, eight by EG\&G/LITCO) were collected during 1994. Tritium was not detected in any of the samples, either onsite or offsite.

\section{Precipitation}

A total of 36 precipitation samples were collected and analyzed for tritium. No samples had detectable concentrations of tritium. 
Distant vs. Boundary Gross Beta

Concentrations (1985-1989)

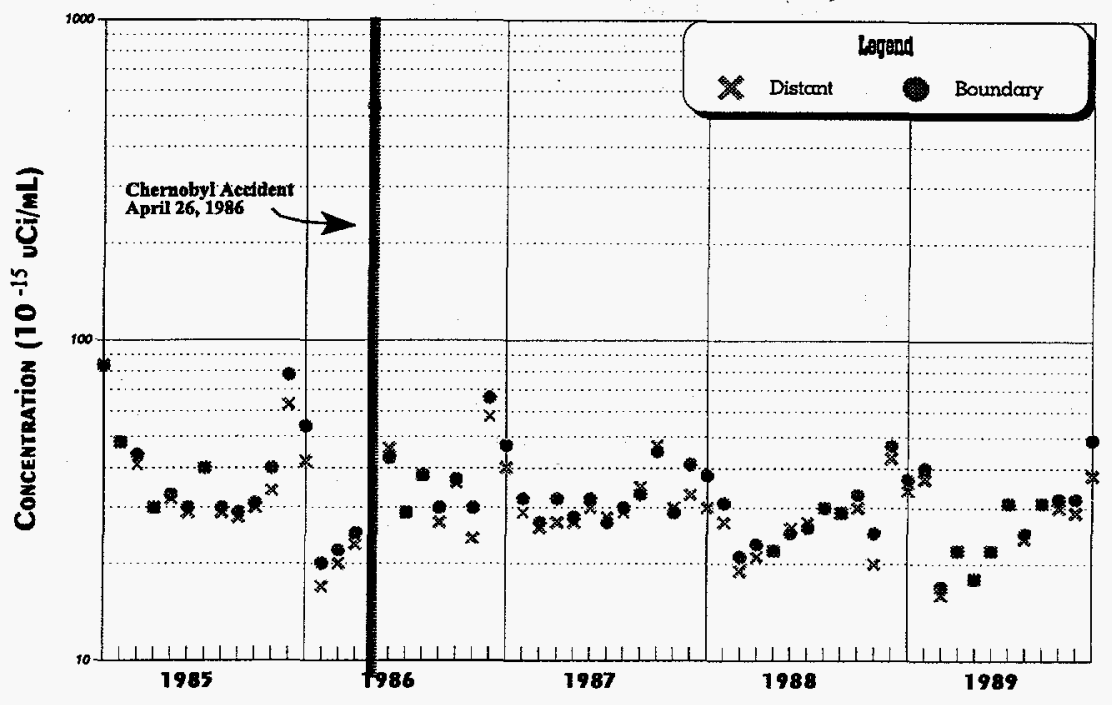

Distant vs. INEL Gross Beta

Concentrations (1985-1989)

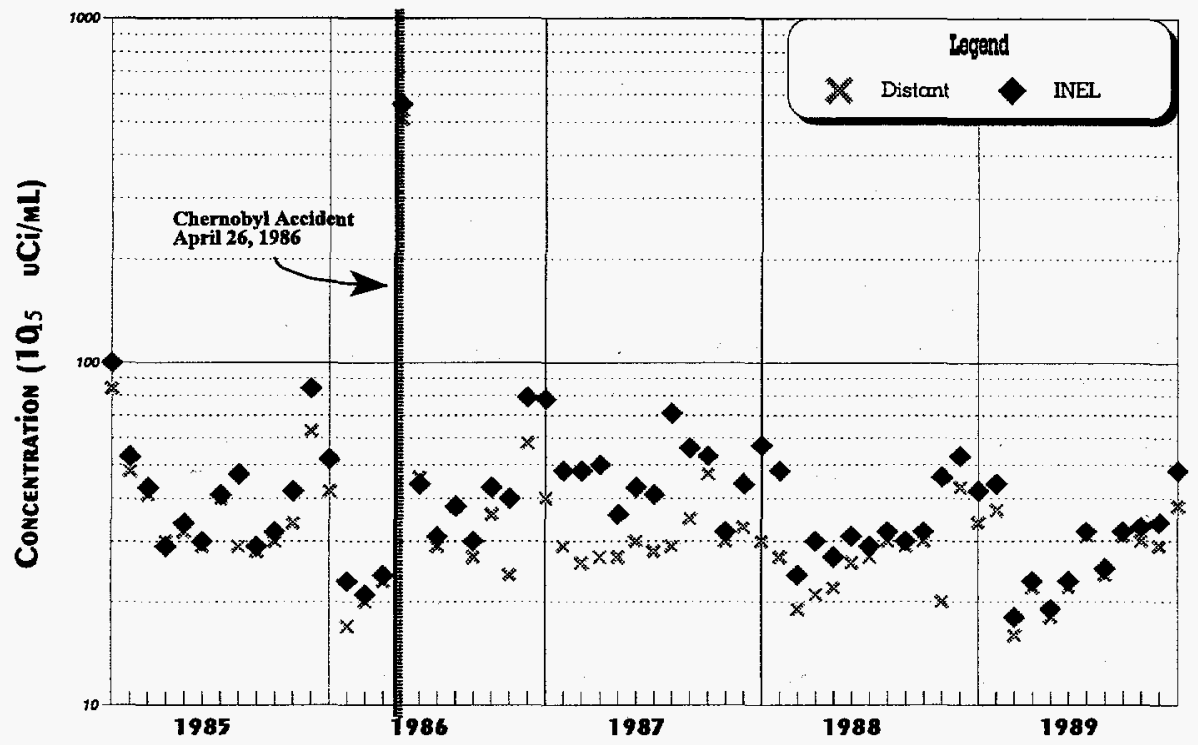

Figure 4.5 Monthly Gross Beta Concentrations (1985-1989) 
Distant vs. Boundary Gross Beta

Concentrations (1990-1994)

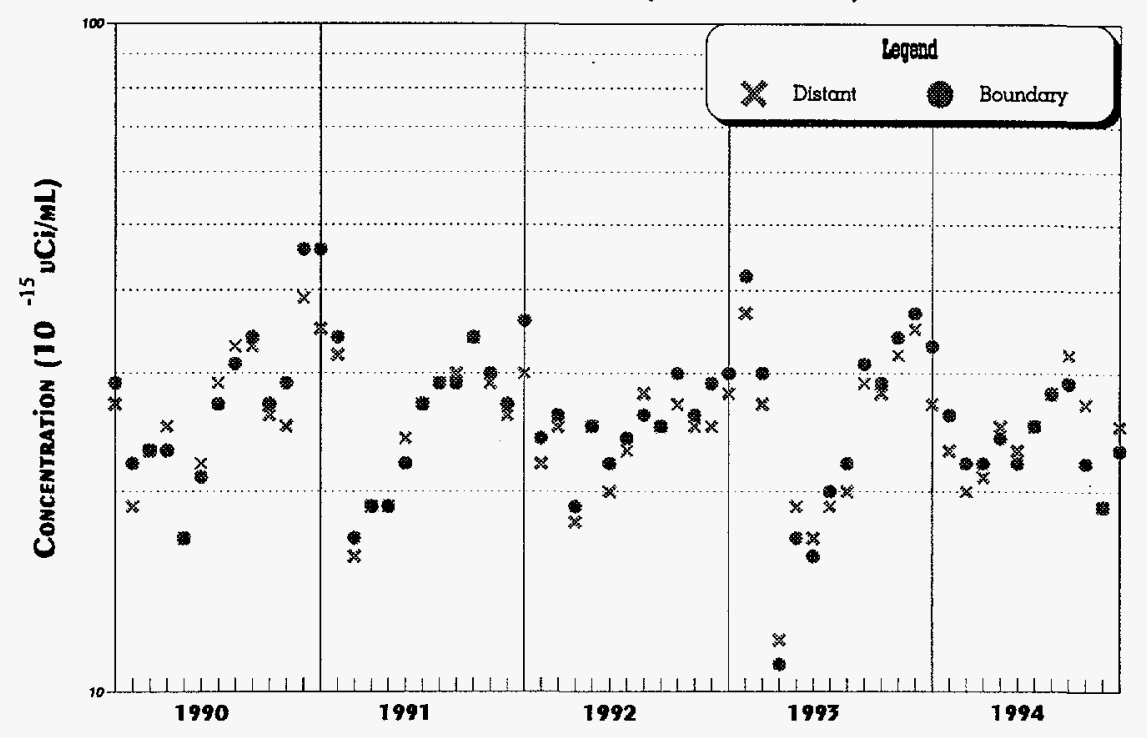

Distant vs. INEL Gross Beta

Concentrations (1990-1994)

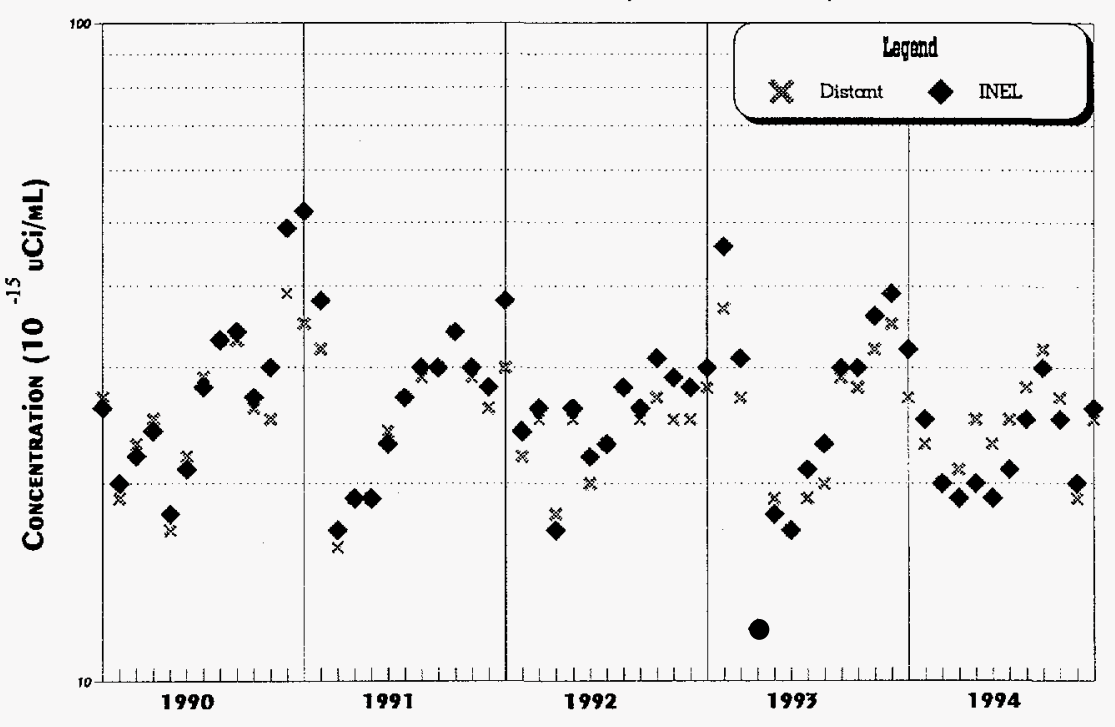

Figure 4.5 (Continued) Monthly Gross Beta Concentrations (1990-1994) 


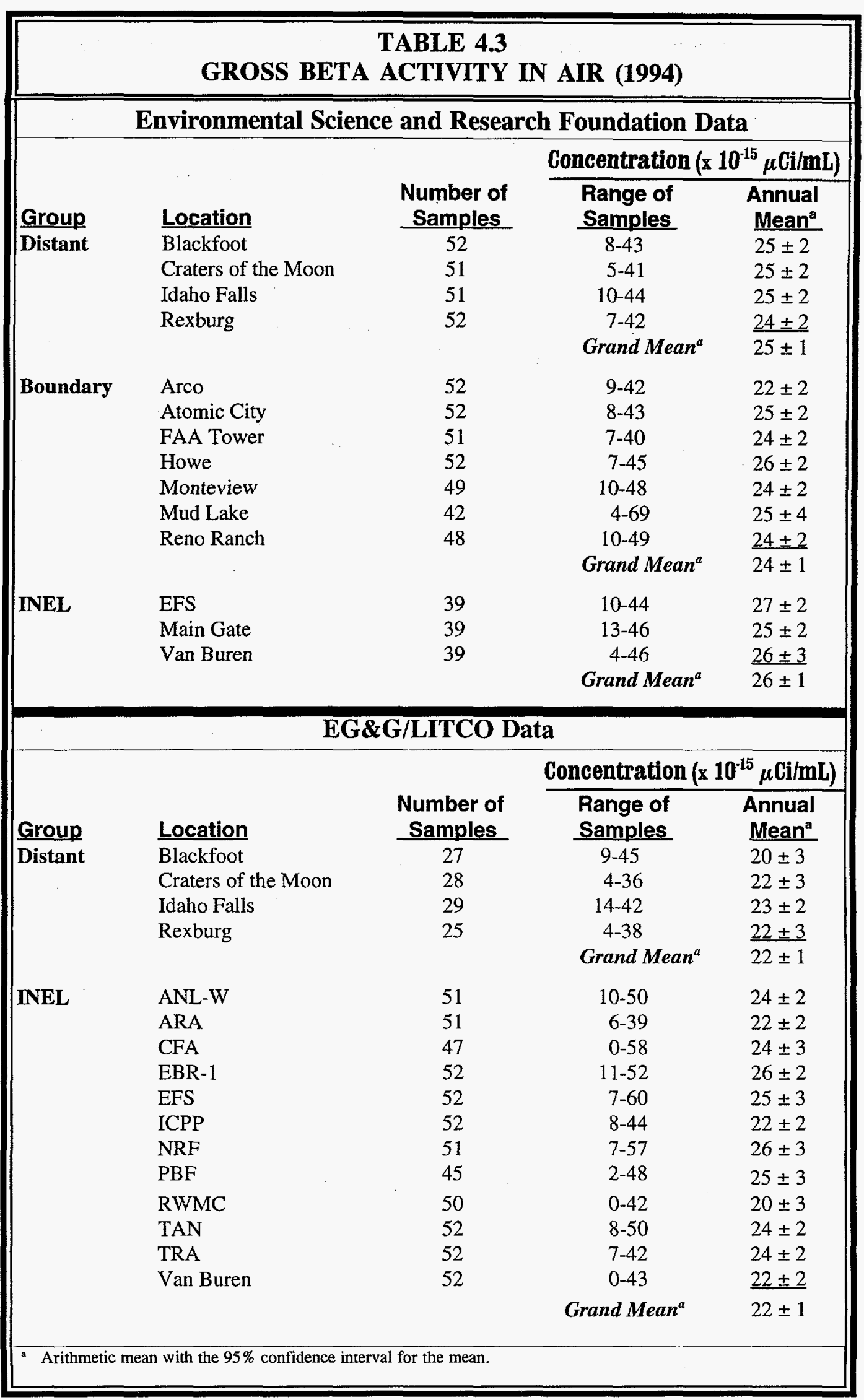




\begin{tabular}{|c|c|c|c|c|c|}
\hline \multicolumn{6}{|c|}{$\begin{array}{c}\text { TABLE } 4.4 \\
\text { MANMADE RADIONUCLIDES IN AIR (1994) }\end{array}$} \\
\hline \multicolumn{6}{|c|}{ Environmental Science and Research Foundation Data } \\
\hline Radionuclide & Quarter & Location & $\begin{array}{c}\text { Quarterly Result } \\
\pm 2 \mathrm{~s} \\
\left(\mathrm{x} 10^{-15} \mu \mathrm{Ci} / \mathrm{mL}\right)\end{array}$ & $\begin{array}{c}\text { Annual Mean } \\
\pm 95 \% \text { C.I. } \\
\left(\times 10^{-15} \mu \mathrm{Ci} / \mathrm{mL}\right)\end{array}$ & $\% \mathrm{DCG}^{\mathrm{b}}$ \\
\hline \multirow{3}{*}{${ }^{90} \mathrm{Sr}$} & First & Mud Lake & $0.5 \pm 0.2$ & $0.1 \pm 5.9$ & 0.0008 \\
\hline & Second & Arco & $0.15 \pm 0.14$ & $0.1 \pm 0.9$ & 0.001 \\
\hline & Second & EFS & $7 \pm 6$ & $0.7 \pm 4.9$ & 0.00007 \\
\hline \multicolumn{6}{|c|}{ EG\&G/LITCO Data } \\
\hline \multirow{12}{*}{$\begin{array}{l}\text { Radionuclide } \\
{ }^{54} \mathrm{Mn} \\
{ }^{65} \mathrm{Zn}\end{array}$} & Quarter & Location & $\begin{array}{c}\begin{array}{c}\text { Qtrly Result } \\
\pm 2 s \\
\left(\times 10^{-15} \mu \mathrm{Ci} / \mathrm{mL}\right)\end{array} \\
\end{array}$ & $\begin{array}{c}\text { Annual Mean } \\
\pm 95 \% \text { C.1. } \\
\left(\times 10^{-15} \mu \mathrm{Ci} / \mathrm{mL}\right)\end{array}$ & $\% \mathrm{DCG}^{\mathrm{b}}$ \\
\hline & Third & $\overline{\text { ARA }}$ & $2.3 \pm 2.2$ & $0.3 \pm 2.0$ & 0.00001 \\
\hline & First & ANL-W & $2.1 \pm 2.0$ & $4.5 \pm 2.3$ & 0.0009 \\
\hline & & ARA & $2.5 \pm 2.2$ & $4.6 \pm 2.0$ & 0.0007 \\
\hline & & EBR-1 & $1.9 \pm 1.8$ & $4.2 \pm 2.1$ & 0.0007 \\
\hline & & NRF & $2.4 \pm 2.2$ & $4 \pm 12$ & 0.0006 \\
\hline & & RWMC & $1.5 \pm 1.4$ & $4.2 \pm 3.8$ & 0.0008 \\
\hline & Second & TAN & $5 \pm 4$ & $4.2 \pm 2.5$ & 0.0007 \\
\hline & Third & CFA & $7 \pm 6$ & $6.2 \pm 5.2$ & 0.001 \\
\hline & & NRF & $7 \pm 6$ & $4 \pm 12$ & 0.0006 \\
\hline & & RWMC & $8 \pm 6$ & $4.2 \pm 3.8$ & 0.0007 \\
\hline & & TRA & $7 \pm 6$ & $5.2 \pm 3.0$ & 0.0009 \\
\hline \multirow{6}{*}{${ }^{90} \mathrm{Sr}$} & Second & EFS & $0.15 \pm 0.12$ & $0.04 \pm 0.15$ & 0.0005 \\
\hline & Third & Rexburg & $0.25 \pm 0.15$ & $0.1 \pm 1.9$ & 0.001 \\
\hline & & ICPP & $0.23 \pm 0.14$ & $0.2 \pm 1.1$ & 0.002 \\
\hline & & RWMC & $0.16 \pm 0.14$ & $0.04 \pm 0.13$ & 0.0005 \\
\hline & & Van Buren & $0.11 \pm 0.09$ & $0.09 \pm 0.22$ & 0.001 \\
\hline & rourtil & CFA & $0.23 \pm 0.20$ & $0.1 \pm 1.3$ & 0.002 \\
\hline \multirow{3}{*}{${ }^{94} \mathrm{Nb}$} & First & $\begin{array}{l}\text { EBK-1 } \\
\text { EFS }\end{array}$ & $\begin{aligned} 0.12 & \pm 0.11 \\
0.5 & \pm 0.4\end{aligned}$ & $\begin{array}{c}0.05 \pm 0.09 \\
0.0 \pm 0.7\end{array}$ & 0.0006 \\
\hline & & ICPP & $0.5 \pm 0.4$ & $0.2 \pm 1.2$ & 0.00006 \\
\hline & & Van Buren & $0.7 \pm 0.6$ & $0.28 \pm 0.7$ & 0.0005 \\
\hline \multirow[t]{5}{*}{${ }^{110 \mathrm{~m}} \mathrm{Ag}$} & First & CFA & $0.7 \pm 0.6$ & $1.2 \pm 1.6$ & 0.007 \\
\hline & & ICPP & $0.5 \pm 0.4$ & $0.5 \pm 1.2$ & 0.003 \\
\hline & & PBF & $0.7 \pm 0.6$ & $0.6 \pm 0.5$ & 0.003 \\
\hline & Third & TRA & $2.1 \pm 2.0$ & $1.0 \pm 1.2$ & 0.0005 \\
\hline & Fourth & ANL-W & $2.1 \pm 1.6$ & $0.8 \pm 1.8$ & 0.0004 \\
\hline \multirow[t]{2}{*}{${ }^{144} \mathrm{Ce}$} & First & EFS & $4 \pm 3$ & $-2.4 \pm 6.3$ & 0.0 \\
\hline & Second & ARA & $15 \pm 10$ & $2.2 \pm 12$ & 0.007 \\
\hline${ }^{203} \mathrm{Hg}$ & Fourth & Van Buren & $5 \pm 4$ & $1.2 \pm 3.9$ & 0.00005 \\
\hline \multirow[t]{2}{*}{${ }^{238} \mathrm{Pu}$} & Third & ICPP & $0.006 \pm 0.004$ & $0.01 \pm 0.10$ & 0.04 \\
\hline & Fourth & ICPP & $0.019 \pm 0.008$ & $0.01 \pm 0.09$ & 0.04 \\
\hline \multirow[t]{2}{*}{${ }^{241} \mathrm{Am}$} & Third & RWMC & $0.005 \pm 0.004$ & $-1.6 \pm 5.0$ & 0.0 \\
\hline & & TRA & $0.0033 \pm 0.0032$ & $-0.9 \pm 2.1$ & 0.0 \\
\hline
\end{tabular}




\section{Water Sampling Results}

The DOE Order governing preparation of Annual Site Environmental Reports (DOE 5400.1) recommends using units of $\mu \mathrm{Ci} / \mathrm{mL}$ for concentrations of radionuclides in water. However, 40 CFR 141 gives the EPA maximum contaminant levels in units of $\mathrm{pCi} / \mathrm{L}$. For the reader's convenience, concentrations of radionuclides in water samples will be shown with exponents that allow easy conversion to EPA units:

$1 \times 10^{-9} \mu \mathrm{Ci} / \mathrm{mL}=1 \mathrm{pCi} / \mathrm{L}$

$1 \times 10^{-6} \mu \mathrm{Ci} / \mathrm{mL}=1000 \mathrm{pCi} / \mathrm{L}$.

\section{Gross Alpha}

Fifty-one offsite samples were collected in 1994 (32 drinking water and 19 surface water samples). Three had gross alpha concentrations above the minimum detectable concentration. The highest reported value, in a surface water sample, was $(2.4 \pm 2.2) \times 10^{-9} \mu \mathrm{Ci} / \mathrm{mL}$. For perspective, this concentration is $8 \%$ of the annual derived concentration guide and about $16 \%$ of the EPA maximum contaminant level.

Of the 291 onsite production well samples collected during 1994, a total of 36 samples contained gross alpha above the minimum detectable concentration (Figure 4.6), the highest of which was $(2.8 \pm 2.4) \times 10^{-9}$ $\mu \mathrm{Ci} / \mathrm{mL}$. This value is $19 \%$ of the EPA maximum contaminant level for gross alpha in drinking water.

All gross alpha concentrations were within the expected concentration range for naturally occurring alpha activity in the aquifer underlying the INEL and surrounding areas. According to USGS reports, alpha-emitting wastes from Site operations have not migrated far from their entrance into the aquifer near ICPP. The offsite gross alpha activity is unlikely to be due to migration of wastes from INEL operations, and all onsite drinking water wells lie outside the migration plumes for alpha-emitting nuclides. The probable source of gross alpha activity is from natural radioactivity that occurs in the Snake River Plain Aquifer.

\section{Gross Beta}

None of the offsite samples contained gross beta activity above the minimum detectable concentration.

Of the 291 onsite production well samples, 55 had concentrations of gross beta that were above the minimum detectable concentration (Figure 4.6), the highest of which was $(8 \pm 2) \times 10^{-9} \mu \mathrm{Ci} / \mathrm{mL}$. This is $16 \%$ of the EPA maximum contaminant level for gross beta in drinking water. The probable source of gross beta activity is from natural radioactivity that occurs in the Snake River Plain Aquifer.

\section{Tritium}

None of the offsite water samples collected during 1994 contained a detectable concentration of tritium.

Water from four of the onsite production wells that were routinely sampled showed detectable concentrations of tritium each month (Table 4.5). Figure 4.7 shows five years of tritium data for these wells along with data from a production well at the Organic Moderated Reactor Experiment facility (OMRE on Figure 4.7) that is no longer in use. 


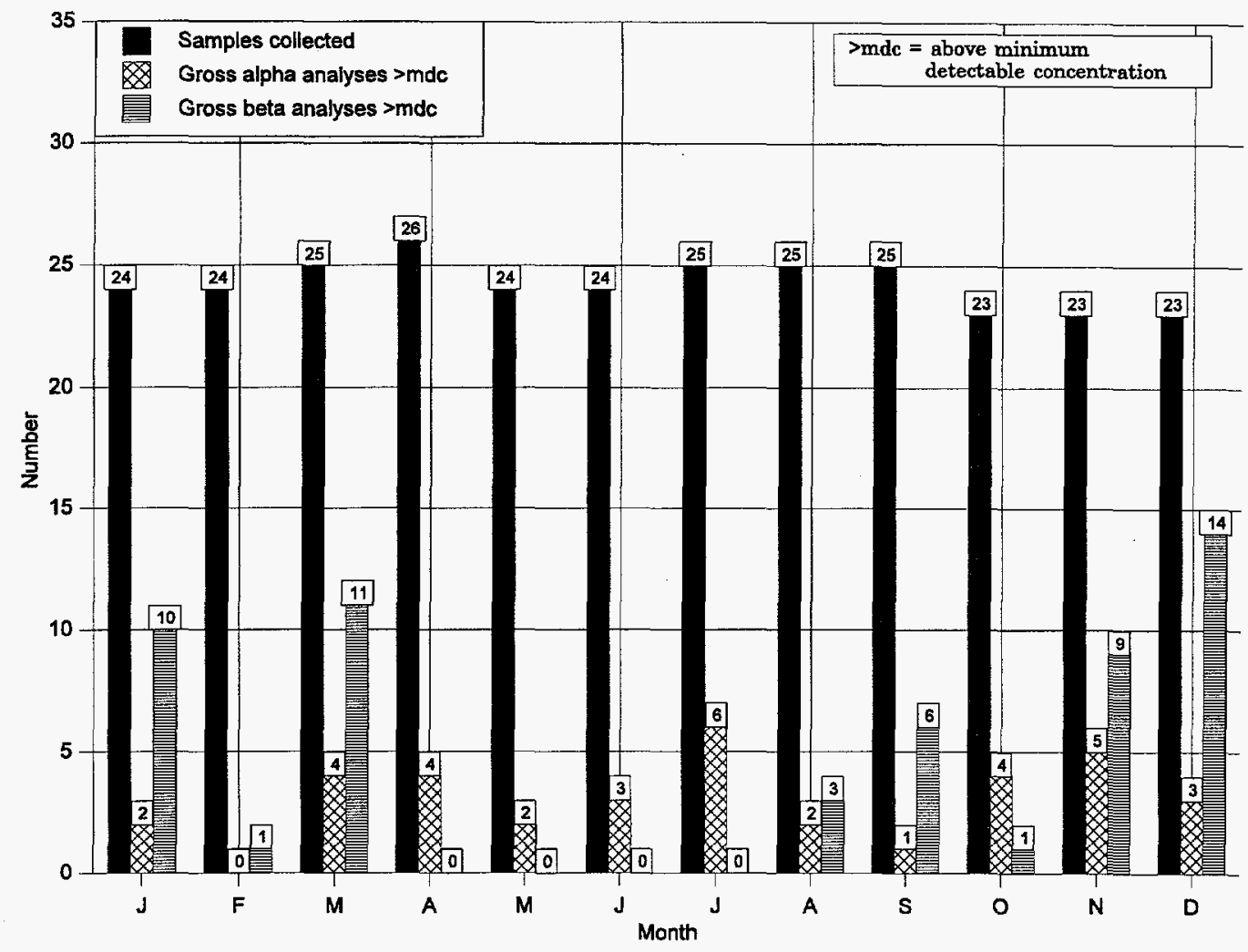

Figure 4.6 Water Samples with Detectable Gross Alpha and Gross Beta Concentrations (1994)

\section{Strontium-90}

Concentrations of ${ }^{90} \mathrm{Sr}$ above the minimum detectable concentration were found in four of the six samples from well ICPP \#1 during 1994. Concentrations reported were consistent with those of previous years (Figure 4.8), ranging from $(0.6 \pm 0.4) \times 10^{-9}$ to $(0.8 \pm 0.6) \times 10^{-9} \mu \mathrm{Ci} / \mathrm{mL}(0.6 \%$ to $0.8 \%$ of the derived concentration guide and $8 \%$ to $10 \%$ of the EPA's maximum contaminant level for ${ }^{90} \mathrm{Sr}$ ). None of the samples from ICPP \#2 showed detectable concentrations of ${ }^{90} \mathrm{Sr}$; one sample from drinking water well ICPP \#4 showed a slightly detectable concentration of $(0.7 \pm 0.6) \times 10^{-9} \mu \mathrm{Ci} / \mathrm{mL}$. This is well below the EPA's maximum contaminant level of $8 \times 10^{-9} \mu \mathrm{Ci} / \mathrm{mL}$ for ${ }^{90} \mathrm{Sr}$.

\section{CFA Worker Dose}

The potential effective dose equivalent to a worker at CFA from radioactivity in water was calculated. CFA was selected because the 


\begin{tabular}{|c|c|c|c|c|c|c|}
\hline \multicolumn{7}{|c|}{$\begin{array}{c}\text { TABLE } 4.5 \\
\text { TRITIUM CONCENTRATIONS IN INEL PRODUCTION WELLS (1994) }\end{array}$} \\
\hline \multirow[b]{2}{*}{ Well Code } & \multicolumn{6}{|c|}{$\begin{array}{l}\text { Tritium Concentration } \\
\qquad\left(\times 10^{6} \mu \mathrm{Ci} / \mathrm{mL}\right)^{\mathrm{a}}\end{array}$} \\
\hline & $\begin{array}{c}\text { \# of } \\
\text { Samples }^{b}\end{array}$ & Minimum $^{\mathbf{c}}$ & Maximum $^{c}$ & Mean $^{d}$ & $\% \mathrm{MCL}^{\mathrm{e}}$ & $\% \mathrm{DCG}$ \\
\hline $\mathrm{CFA}^{\mathrm{f}}$ & 12 & $12.7 \pm 0.8$ & $17.2 \pm 1.0$ & $14.3 \pm 0.8$ & $\frac{72}{72}$ & 0.7 \\
\hline CFA \#1 & 8 & $13.1 \pm 1.2$ & $18.0 \pm 1.0$ & $15.6 \pm 1.7$ & 78 & 0.8 \\
\hline $\mathrm{CFA} \# 2$ & 11 & $12.6 \pm 0.8$ & $14.9 \pm 1.0$ & $14.0 \pm 0.5$ & 70 & 0.6 \\
\hline Rifle Range & 12 & $3.5 \pm 0.6$ & $4.2 \pm 0.6$ & $3.9 \pm 0.1$ & 20 & 0.2 \\
\hline RWMC & 12 & $1.3 \pm 0.4$ & $1.8 \pm 0.4$ & $1.5 \pm 0.1$ & 8 & 0.07 \\
\hline \multicolumn{7}{|c|}{$\begin{array}{l}\text { Equivalent to } \mathrm{pCi} / \mathrm{mL} \text {. } \\
\text { Samples taken only from wells in use at collection time. } \\
\text { Tritium concentration } \pm 2 \text { s. } \\
\text { Arithmetic mean with the } 95 \% \text { confidence interval for the mean. } \\
\text { EPA drinking water } \mathrm{MCL} \text { (maximum contaminant level) for tritium is } 20 \times 10^{-6} \\
\mu \mathrm{Ci} / \mathrm{mL} \text {. } \\
\text { Samples collected from the Central Facilities Area distribution system }\end{array}$} \\
\hline
\end{tabular}

tritium concentrations found in these wells were the highest of any drinking water wells. The 1994 calculation was based on:

Average (mean) tritium concentration for the CFA production well for 1994 as shown in Table 4.5

- Data from a 1990-91 USGS study for ${ }^{129}$ I using the accelerator mass spectrographic analytical technique which indicated that water from CFA \#1 contained ${ }^{129} \mathrm{I}$ at a concentration of $(0.26 \pm 0.05) \times 10^{-9} \mu \mathrm{Ci} / \mathrm{mL}$ (the average of two samples) and water from CFA \#2 had a concentration of $(0.14 \pm 0.03) \times 10^{-9} \mu \mathrm{Ci} / \mathrm{mL}$ (also the average of two samples). For perspective, the proposed EPA drinking water standard for ${ }^{129} \mathrm{I}$ is $21 \times 10^{-9}$ $\mu \mathrm{Ci} / \mathrm{mL}$.
- Water usage information for 1994 showing CFA \#2 was used for approximately $71.5 \%$ of the drinking water and CFA \#1 was used for $28.5 \%$ of the drinking water.

For the 1994 dose calculation, the assumption was made that each worker's total water intake came from the CFA drinking water distribution system. This assumption overestimates the dose because workers typically consume only about half their total intake during working hours and typically work only 240 days rather than 365 days per year. The estimated effective dose equivalent to a worker from consuming all drinking water at CFA during 1994 was 0.7 mrem, 18\% of the EPA standard of 4 mrem for community drinking water systems. 
Tritium Concentrations in INEL

Production Wells (1990-1994)

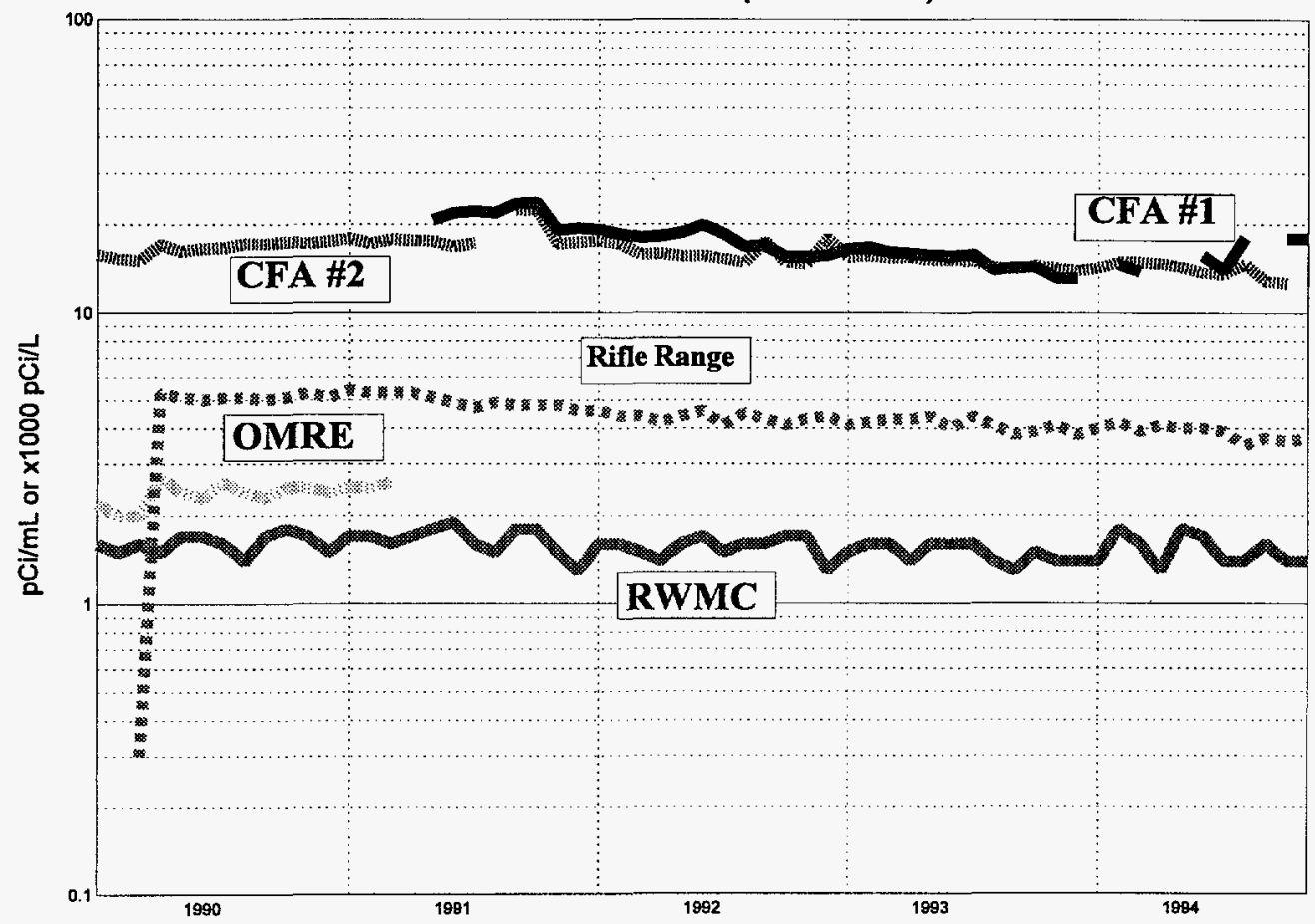

Figure 4.7 Tritium Concentrations in INEL Production Wells (1990-1994)

\section{Sr-90 Concentration in well ICPP \#1}

(1990-1994)

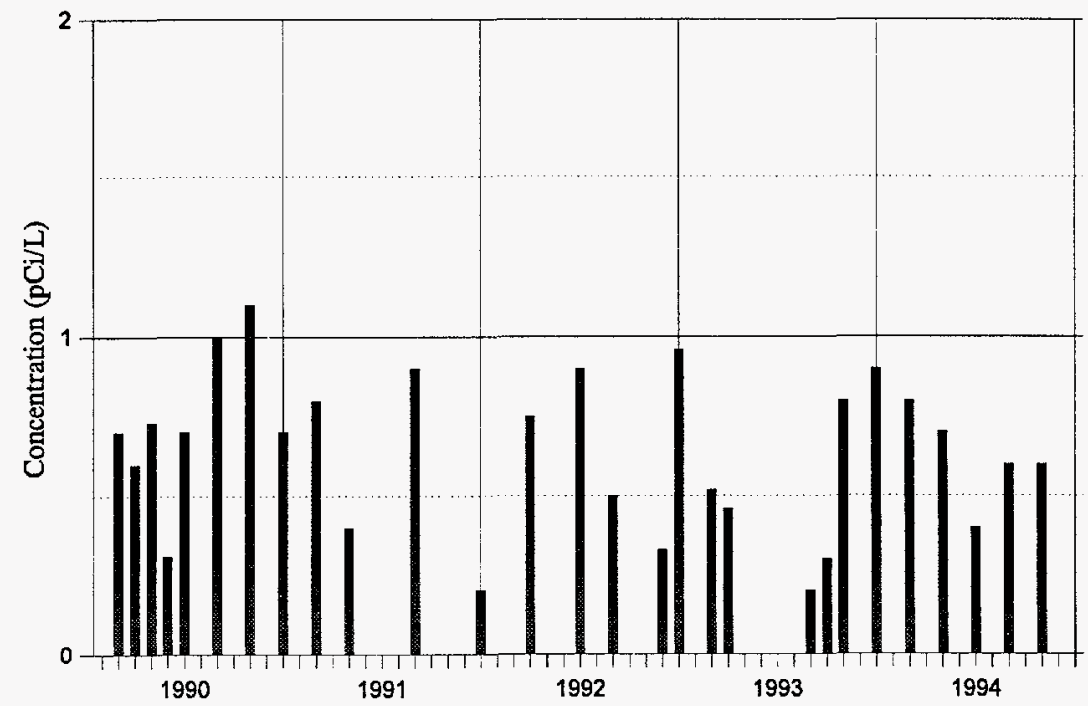

Figure 4.8 ${ }^{90} \mathrm{Sr}$ concentration in well ICPP \#1 (1990-1994) 


\section{Foodstuff Sampling Results}

Milk. None of the 151 milk samples collected during 1994 contained a detectable concentration of ${ }^{131} \mathrm{I}$. Tritium was not detected in any of the nine samples analyzed for that radionuclide. One of the three samples from boundary locations, at Arco, had a detectable ${ }^{90} \mathrm{Sr}$ concentration of $(1.5 \pm 1.4) \times 10^{-9} \mu \mathrm{Ci} / \mathrm{mL}$; one of the six samples from distant locations, a Dietrich sample, also contained ${ }^{90} \mathrm{Sr}$ at a concentration of $(2.7 \pm 2.4) \times 10^{-9} \mu \mathrm{Ci} / \mathrm{mL}$. Group means for the distant and boundary locations were at 0.8 and $0.4 \times 10^{-9} \mu \mathrm{Ci} / \mathrm{mL}$, respectively. All levels of ${ }^{90} \mathrm{Sr}$ in milk were consistent with those reported by the EPA as resulting from world-wide fallout deposited on soil, then taken up by consumption of grass by cows .

Lettuce. One sample, from Blackfoot, contained a ${ }^{137} \mathrm{Cs}$ concentration of $(3.3 \pm 1.2) \mathrm{x}$ $10^{-6} \mu \mathrm{Ci} / \mathrm{g}$. This radionuclide's presence only in a sample from a distant, control station suggests that an INEL source is unlikely. All seven samples, three from a distant location and four from a boundary location, had ${ }^{90} \mathrm{Sr}$ concentrations above the minimum detectable concentration (Table 4.6). The distant (control) locations had average ${ }^{90} \mathrm{Sr}$ concentrations slightly higher than the boundary locations. The detectable concentrations found are attributed to worldwide fallout.

Wheat. No manmade gamma-emitting radionuclides were found above the minimum detectable concentration in 1994 wheat samples. Measurable concentrations of ${ }^{90} \mathrm{Sr}$ were seen in ten of eleven samples (Table 4.7). No differences have been seen in ${ }^{90} \mathrm{Sr}$ concentrations at distant and boundary locations over the past several years. Concentrations of

a. U.S. Environmental Protection Agency, Environmental Radiation Data Reports 70-73, 1993. this radionuclide are likely due to worldwide fallout.

Potatoes. No gamma-emitting radionuclides were observed at the five locations sampled (three distant and two boundary). One boundary station (Mud Lake) had detectable ${ }^{90} \mathrm{Sr}$ at $(4 \pm 2) \times 10^{-9} \mu \mathrm{Ci} / \mathrm{g}$ dry weight. There are no other indicators of elevated levels of ${ }^{90} \mathrm{Sr}$ in foodstuffs being due to INEL activities. The radioactivity is attributed to worldwide fallout.

Sheep. Tissues sampled (muscle, liver, and thyroid) of sheep grazing on the INEL indicated no detectable levels of gamma-emitting radionuclides or ${ }^{131} \mathrm{I}$. (While animal thyroids are not likely direct contributors to human radiation dose through the ingestion pathway, they are good indicators of any changes in environmental levels of radioiodine.)

Game. Five game animals, four pronghorn antelope and one elk, were sampled in 1994. Two were killed in the vicinity of TAN, one near the RWMC, one near ANL-W, and one along US Highway 20 . No manmade radionuclides were detected in thyroid or liver samples. A pronghorn collected near TAN had a ${ }^{137} \mathrm{Cs}$ concentration just above the minimum detectable concentration at $(7 \pm 6) \times 10^{-9} \mu \mathrm{Ci} / \mathrm{g}$ in muscle. The Big Lost River did not contain water during 1994, thus no fish were collected.

\section{Soil}

In 1994, all offsite soil samples were analyzed for gamma-emitting radionuclides. All offsite surface samples $(0-5 \mathrm{~cm})$ were also analyzed for ${ }^{90} \mathrm{Sr}$ and alpha-emitting radionuclides (Table 4.8). The data are reported in units of activity per gram of soil ( $\mathrm{pCi} / \mathrm{g}$ dry weight) and also in units of areal activity $\left(\mathrm{nCi} / \mathrm{m}^{2}\right)$, which is the total activity in each soil 


\begin{tabular}{|c|c|c|c|c|c|}
\hline \multicolumn{6}{|c|}{$\begin{array}{c}\text { Table } 4.6 \\
{ }^{90} \text { Sr Concentrations in Garden Lettuce }(1990-1994)\end{array}$} \\
\hline \multirow[b]{2}{*}{$\begin{array}{l}\text { Sample Location } \\
\text { Distant Group: }\end{array}$} & \multicolumn{5}{|c|}{${ }^{90} \mathrm{Sr}$ Concentration $\left(\mathrm{x} 10^{9} \mu \mathrm{Ci} / \mathrm{g}\right.$ dry weight) ${ }^{\mathrm{a}}$} \\
\hline & 1990 & 1991 & 1992 & 1993 & 1994 \\
\hline $\begin{array}{l}\text { Blackfoot } \\
\text { Carey } \\
\text { Idaho Falls } \\
\text { Pocatello }\end{array}$ & $\begin{array}{c}150 \pm 60 \\
180 \pm 40 \\
\pm \\
210 \pm 60 \\
\end{array}$ & $\begin{array}{l}170 \pm 80 \\
210 \pm 80 \\
170 \pm 100 \\
190 \pm 40 \\
\end{array}$ & $\begin{array}{c}\cdots \\
200 \pm 40 \\
230 \pm 40 \\
80 \pm 40 \\
\end{array}$ & $\begin{array}{l}-30 \pm 60 \\
-70 \pm 50 \\
-80 \pm 50 \\
180 \pm 140 \\
\end{array}$ & $\begin{array}{c}160 \pm 80 \\
130 \pm 40 \\
120 \pm 40 \\
\pm \mathrm{b} \\
\end{array}$ \\
\hline Pocatello & $180 \pm 70$ & $190 \pm 30$ & $170 \pm 200$ & $0 \pm 190$ & $140 \pm 50$ \\
\hline \multicolumn{6}{|l|}{ Boundary Group: } \\
\hline $\begin{array}{l}\text { Arco } \\
\text { Atomic City }\end{array}$ & $\begin{array}{r}50 \pm 40 \\
140 \pm 40\end{array}$ & $\begin{array}{c}80 \pm 40 \\
310 \pm 120\end{array}$ & $\begin{array}{r}50 \pm 40 \\
210 \pm 60\end{array}$ & $\begin{array}{r}90 \pm 90 \\
-80 \pm 60\end{array}$ & $\begin{array}{r}50 \pm 40 \\
200 \pm 60\end{array}$ \\
\hline $\begin{array}{l}\text { Howe } \\
\text { Monteview } \\
\text { Mud Lake/Terreton }\end{array}$ & $\begin{array}{l}50 \pm 40 \\
\mathrm{NS} \\
90 \pm 60\end{array}$ & $\begin{array}{l}50 \pm 40 \\
\mathrm{NS} \\
170 \pm 80\end{array}$ & $\begin{array}{l}80 \pm 40 \\
\mathrm{NS} \\
150 \pm 40\end{array}$ & $\begin{array}{c}N^{d} \\
210 \pm 80 \\
40 \pm 70\end{array}$ & $\begin{array}{c}N^{d} \\
110 \pm 40 \\
70 \pm 60\end{array}$ \\
\hline$M e a n^{c}$ & $80 \pm 70$ & $150 \pm 160$ & $\overline{120 \pm 110}$ & $70 \pm 190$ & $\overline{110 \pm 100}$ \\
\hline $\begin{array}{l}\text { Analytical results } \pm 2 \text { s. Approx } \\
\text { Sample lost in preparation or ana } \\
\text { A Arithmetic mean with the } 95 \% \mathrm{cc} \\
\text { No sample was collected at this } 1 \\
\end{array}$ & inimum d & encentration $\mathrm{f}$ & in lettuce is & $10^{-9} \mu \mathrm{Ci} / \mathrm{g} \mathrm{dr}$ & \\
\hline
\end{tabular}

sample divided by the surface area $\left(0.039 \mathrm{~m}^{2}\right)$ of the sample.

Surface soil concentrations of ${ }^{137} \mathrm{Cs}$, ${ }^{90} \mathrm{Sr},{ }^{238} \mathrm{Pu},{ }^{239 / 240} \mathrm{Pu}$, and ${ }^{241} \mathrm{Am}$, as measured from 1970-75, are compared to biennial samples since 1978. The 1976 data are not included because the sampling locations used that year are not considered to be representative of the area. Three samples from 1984, Mud Lake No. 1, Mud Lake No. 2, and Crystal Ice Caves, were excluded from 1984 data because the concentrations were uncharacteristically low compared to previous years. This may have been caused by disturbance (farming, erosion, vehicular traffic, etc.) of the sampling locations. These sampling locations, plus the location at
Monteview, were re-evaluated and moved to more representative undisturbed locations in 1986.

The 1994 boundary group average concentrations were not statistically greater than the distant group concentrations for any radionuclide. It is concluded the manmade radionuclides detected are present as a result of worldwide fallout.

\section{Environmental Dosimeters}

The measured cumulative exposure for offsite locations for the time period from November 1993 to November 1994 is shown in Table 4.9. For purposes of comparison, annual 


\begin{tabular}{|c|c|c|c|c|c|c|}
\hline \multicolumn{7}{|c|}{$\begin{array}{c}\text { Table } 4.7 \\
{ }^{90} \mathrm{Sr} \text { Concentrations in Wheat }(1990-1994)\end{array}$} \\
\hline \multirow[b]{2}{*}{ Sample Location } & & \multicolumn{5}{|c|}{${ }^{90} \mathrm{Sr}$ Concentration (x 10 ${ }^{9} \mu \mathrm{Ci} / \mathrm{g}$ dry weight) ${ }^{\mathrm{a}}$} \\
\hline & & 1990 & 1991 & 1992 & 1993 & 1994 \\
\hline \multicolumn{7}{|l|}{ Distant Group: } \\
\hline American Falls & & $10 \pm 3$ & $10 \pm 4$ & $11 \pm 2$ & $2 \pm 2$ & $7 \pm 2$ \\
\hline Blackfoot & & $21 \pm 4$ & $10 \pm 3$ & $7 \pm 2$ & $2 \pm 4$ & $7 \pm 2$ \\
\hline Carey & & $N^{b}$ & NS & $10 \pm 2$ & $2 \pm 4$ & $2 \pm 2$ \\
\hline Dietrich & & $9 \pm 3$ & $6 \pm 3$ & NS & $-1 \pm 4$ & $3 \pm 2$ \\
\hline Idaho Falls & & $13 \pm 4$ & $9 \pm 3$ & $9 \pm 2$ & $0 \pm 3$ & $6 \pm 2$ \\
\hline \multirow[t]{2}{*}{ Minidoka } & & $12 \pm 4$ & $8 \pm 4$ & $7 \pm 2$ & $4 \pm 4$ & $\underline{6 \pm 2}$ \\
\hline & $\operatorname{Mean}^{c}$ & $13 \pm 6$ & $8 \pm 2$ & $9 \pm 2$ & $2 \pm 2$ & $5 \pm 2$ \\
\hline \multicolumn{7}{|l|}{ Boundary Group: } \\
\hline Arco & & $13 \pm 4$ & $10 \pm 3$ & $10+2$ & $-1+3$ & $4+2$ \\
\hline Monteview & & $9 \pm 3$ & $3 \pm 3$ & $9 \pm 2$ & $1 \pm 4$ & $7 \pm 3$ \\
\hline Mud Lake & & $7 \pm 3$ & $9 \pm 3$ & $4 \pm 2$ & $2 \pm 4$ & $5 \pm 2$ \\
\hline Tabor & & $10 \pm 3$ & $15 \pm 4$ & $8 \pm 2$ & $0 \pm 6$ & $8 \pm 2$ \\
\hline \multirow[t]{2}{*}{ Terreton } & & $12 \pm 3$ & $5 \pm 3$ & $3 \pm 2$ & $1 \pm 2$ & $5 \pm 2$ \\
\hline & $\operatorname{Mean}^{c}$ & $10 \pm 3$ & $8 \pm 6$ & $7 \pm 4$ & $1 \pm 1$ & $6 \pm 2$ \\
\hline $\begin{array}{l}\text { Analytical results } \pm 2 \\
\text { No sample was collec } \\
\text { Arithmetic mean with }\end{array}$ & s locan & ng tue & & & & \\
\hline
\end{tabular}

exposures from 1990-93 are also included for each location.

The mean annual exposures for distant and boundary community locations in 1994 were $126 \pm 3 \mathrm{mR}$ and $126 \pm 2 \mathrm{mR}$, respectively, as measured by thermoluminescent dosimeters (TLDs). The average exposure of the offsite groups is approximately equivalent to 130 mrem, when a dose equivalent conversion factor of $1.03^{\mathrm{a}}$ was used to convert from $\mathrm{mR}$ to mrem in tissue.

Table 4.10 summarizes the calculated effective dose equivalent an individual receives on the Snake River Plain from various background radiation sources. The terrestrial

a. R. C. Yoder, et al., Confirmation of Conversion Factors Relating Exposure and Dose-Equivalent Index Presented in ANSI N13.71, NUREG/CR-1057, PNL-3219: Pacific Northwest Laboratory, Richland, WA, 1979. portion of this value, which is based on soil sampling for natural radionuclides in 1976, varies from year to year, depending on the amount of snow cover ${ }^{b}$. For 1994, this resulted in about an $8 \%$ dose reduction due to snow cover which reached a maximum depth of six inches in February.

The cosmic component varies primarily with altitude. The average annual dose equivalent of 26 mrem at sea level essentially doubles with each $2000 \mathrm{~m}(6560 \mathrm{ft})$ increase in altitude ${ }^{c}$. The INEL Site altitude is

b. National Council on Radiation Protection and Measurements, Ionizing Radiation Exposure of the Population of the United States, NCRP Report No. 93, September 1, 1987.

c. National Council on Radiation Protection and Measurements, Exposure of the Population in the United States and Canada from Natural Background Radiation, NCRP Report No. 94, December 30. 1987. 
TABLE 4.8

RADIONUCLIDES IN OFFSITE SURFACE (0-5 cm. DEPTH) SOIL (1970-1994)

\begin{tabular}{|c|c|c|c|c|c|c|c|c|}
\hline \multirow[b]{2}{*}{ Nuclide } & \multirow[b]{2}{*}{ Year } & \multicolumn{2}{|r|}{$\mathrm{pCi} / \mathrm{g}$} & \multicolumn{2}{|r|}{$\mathrm{nCi}^{2} \mathrm{~m}^{2}$} & \multirow[b]{2}{*}{$\begin{array}{l}\text { Number of } \\
\text { Samples }\end{array}$} & \multicolumn{2}{|c|}{$\sim \mathrm{MDC}^{\mathrm{a}}$} \\
\hline & & $\begin{array}{c}\text { Geometric } \\
\text { Mean }\end{array}$ & $\begin{array}{l}\text { 95\% Confidence } \\
\text { Interval }^{\mathrm{b}}\end{array}$ & $\begin{array}{l}\text { Geometric } \\
\text { Mean }\end{array}$ & $\begin{array}{c}\text { 95\% Confidence } \\
\text { Interval }^{\mathbf{b}}\end{array}$ & & $\mathrm{pCi} / \mathrm{g}$ & $\mathrm{nCi} / \mathrm{m}^{2}$ \\
\hline \multirow[t]{10}{*}{${ }^{137} \mathrm{Cs}$} & $1970-75^{\mathrm{c}}$ & $\overline{0.94}$ & $\overline{0.78-1.1}$ & 5 & $49-59$ & 60 & 0.01 & 1 \\
\hline & 1978 & 0.94 & $0.72-1.2$ & 58 & $44-75$ & 10 & & \\
\hline & 1980 & 0.64 & $0.46-0.90$ & 41 & $29-57$ & 10 & & \\
\hline & 1982 & 0.90 & $0.64-1.2$ & 44 & $31-62$ & 10 & & \\
\hline & 1984 & 0.69 & $0.49-0.97$ & 43 & $31-60$ & 7 & & \\
\hline & 1986 & 0.81 & $0.54-1.2$ & 48 & $34-67$ & 13 & & \\
\hline & 1988 & 0.66 & $0.34-1.3$ & 47 & $46-48$ & 12 & & \\
\hline & 1990 & 0.73 & $0.54-0.99$ & 43 & $33-56$ & 12 & & \\
\hline & 1992 & 0.78 & $0.56-1.09$ & 42 & $31-57$ & 12 & & \\
\hline & 1994 & 0.75 & $0.55-1.03$ & 36 & $28-47$ & 12 & & \\
\hline \multirow[t]{10}{*}{${ }^{90} \mathrm{Sr}$} & $1970-75$ & 0.54 & $0.43-0.59$ & 34 & $31-37$ & 55 & 0.09 & 10 \\
\hline & 1978 & 0.52 & $0.40-0.68$ & 32 & $23-45$ & 10 & & \\
\hline & 1980 & 0.35 & $0.25-0.49$ & 22 & $15-33$ & 10 & & \\
\hline & 1982 & 0.37 & $0.26-0.52$ & 18 & $11-29$ & 10 & & \\
\hline & 1984 & 0.45 & $0.32-0.63$ & 28 & $20-39$ & 7 & & \\
\hline & 1986 & 0.52 & $0.43-0.62$ & 30 & $25-37$ & 13 & & \\
\hline & 1988 & 0.38 & $0.28-0.53$ & 23 & $17-31$ & 12 & & \\
\hline & 1990 & 0.30 & $0.22-0.40$ & 17 & $13-23$ & 12 & & \\
\hline & 1992 & 0.26 & $0.17-0.41$ & 14 & $9-21$ & 12 & & \\
\hline & 1994 & 0.35 & $0.27-0.44$ & 16 & $12-22$ & $10^{d}$ & & \\
\hline \multirow[t]{10}{*}{${ }^{238} \mathrm{Pu}$} & $1970-75$ & 0.0028 & $0.0023-0.0034$ & 0.15 & $0.13-0.18$ & 55 & 0.002 & 0.1 \\
\hline & 1978 & 0.0010 & $0.0005-0.0020$ & 0.06 & $0.03-0.11$ & 10 & & \\
\hline & 1980 & 0.0007 & $0.0005-0.0009$ & 0.05 & $0.04-0.07$ & 10 & & \\
\hline & 1982 & 0.0011 & $0.0007-0.0017$ & 0.05 & $0.03-0.08$ & 10 & & \\
\hline & 1984 & 0.0015 & $0.0008-0.0027$ & 0.08 & $0.04-0.15$ & 7 & & \\
\hline & 1986 & 0.0021 & $0.0010-0.0027$ & 0.12 & $0.06-0.27$ & 13 & & \\
\hline & 1988 & 0.0014 & $0.0009-0.0024$ & 0.09 & $0.05-0.14$ & 12 & & \\
\hline & 1990 & 0.0006 & $0.0003-0.0012$ & 0.04 & $0.02-0.09$ & 12 & & \\
\hline & 1992 & 0.0013 & $0.0009-0.0019$ & 0.07 & $0.05-0.10$ & 12 & & \\
\hline & 1994 & 0.0013 & $0.0009-0.0019$ & 0.06 & $0.05-0.09$ & 12 & & \\
\hline \multirow[t]{10}{*}{${ }^{239 / 240} \mathbf{P u}$} & $1970-75$ & 0.020 & $0.017-0.024$ & 1.06 & $0.96-1.17$ & 54 & 0.002 & 0.1 \\
\hline & 1978 & 0.018 & $0.013-0.025$ & 1.09 & $0.78-1.53$ & 10 & & \\
\hline & 1980 & 0.010 & $0.006-0.017$ & 0.63 & $0.37-1.07$ & 10 & & \\
\hline & 1982 & 0.022 & $0.016-0.031$ & 1.06 & $0.76-1.48$ & 10 & & \\
\hline & 1984 & 0.016 & $0.011-0.022$ & 1.02 & $0.73-1.43$ & 7 & & \\
\hline & 1986 & 0.018 & $0.012-0.027$ & 1.05 & $0.70-1.58$ & 13 & & \\
\hline & 1988 & 0.021 & $0.015-0.029$ & 1.22 & $0.91-1.65$ & 12 & & \\
\hline & 1990 & 0.024 & $0.017-0.035$ & 1.43 & $1.01-2.03$ & 12 & & \\
\hline & 1992 & 0.021 & $0.013-0.033$ & 1.52 & $0.74-1.70$ & 12 & & \\
\hline & 1994 & 0.021 & $0.013-0.033$ & 1.01 & $0.67-1.53$ & 12 & & \\
\hline \multirow[t]{10}{*}{${ }^{241} \mathrm{Am}$} & $1970-75$ & 0.004 & $0.003-0.005$ & 0.24 & $0.20-0.29$ & 37 & 0.003 & 0.2 \\
\hline & 1978 & 0.006 & 0.004-0.009 & 0.38 & $0.29-0.49$ & 10 & & \\
\hline & 1980 & 0.003 & $0.002-0.0004$ & 0.20 & $0.14-0.28$ & 10 & & \\
\hline & 1982 & 0.004 & $0.003-0.006$ & 0.21 & $0.13-0.34$ & 10 & & \\
\hline & 1984 & 0.004 & $0.002-0.007$ & 0.26 & $0.15-0.44$ & 7 & & \\
\hline & 1986 & 0.004 & $0.002-0.007$ & 0.23 & $0.12-0.41$ & 13 & & \\
\hline & 1988 & 0.005 & $0.004-0.008$ & 0.31 & $0.22-0.45$ & 12 & & \\
\hline & 1990 & 0.005 & $0.003-0.008$ & 0.27 & $0.16-0.45$ & 12 & & \\
\hline & 1992 & 0.004 & $0.002-0.006$ & 0.19 & $0.12-0.31$ & 12 & & \\
\hline & 1994 & 0.004 & $0.002-0.006$ & 0.17 & $0.11-0.28$ & 12 & & \\
\hline \multicolumn{9}{|c|}{$\begin{array}{l}\text { Approximate minimum detectable concentration. } \\
\text { The } 95 \% \text { confidence interval for the geometric mean. } \\
\text { Excluding } 1972 \text { in which no samples were taken. } \\
\text { Two }{ }^{91} \mathrm{Sr} \text { analyses were not yet completed. }\end{array}$} \\
\hline
\end{tabular}




\begin{tabular}{|c|c|c|c|c|c|}
\hline \multicolumn{6}{|c|}{$\begin{array}{c}\text { TABLE } 4.9 \\
\text { ENVIRONMENTAL RADIATION EXPOSURES (1990-1994) }\end{array}$} \\
\hline \multirow[b]{2}{*}{$\begin{array}{l}\frac{\text { Location }}{\text { Distant Group: }}\end{array}$} & \multicolumn{5}{|c|}{$\begin{array}{l}\text { Annual Exposure } \\
\qquad(\mathrm{mR})^{\mathrm{a}}\end{array}$} \\
\hline & 1990 & 1991 & 1992 & 1993 & 1994 \\
\hline $\begin{array}{l}\text { Aberdeen } \\
\text { Blackfoot } \\
\text { Craters of the Moon } \\
\text { Idaho Falls } \\
\text { Minidoka } \\
\text { Rexburg } \\
\text { Roberts } \\
\quad \text { Mean }^{e}\end{array}$ & $\begin{array}{r}114 \pm 4 \\
118 \pm 5 \\
116 \pm 4 \\
126 \pm 4 \\
99 \pm 4 \\
110 \pm 4 \\
125 \pm 5 \\
115 \pm 9\end{array}$ & $\begin{array}{l}126 \pm 5 \\
122 \pm 6 \\
131 \pm 10 \\
127 \pm 6 \\
103 \pm 4 \\
113 \pm 5 \\
137 \pm 8 \\
123 \pm 11\end{array}$ & $\begin{array}{c}--^{b} \\
122 \pm 4 \\
132 \pm 6 \\
138 \pm 9 \\
129 \pm 6 \\
109 \pm 4 \\
\frac{136 \pm 6}{128 \pm 11}\end{array}$ & $\begin{array}{r}99 \pm 3 \\
111 \pm 4 \\
110 \pm 7 \\
116 \pm 4 \\
--{ }^{d} \\
107 \pm 4 \\
124 \pm 4 \\
111 \pm 9\end{array}$ & $\begin{array}{l}120 \pm 4 \\
125 \pm 5 \\
133 \pm 10 \\
120 \pm 6 \\
120 \pm 6 \\
138 \pm 4 \\
126 \pm 3\end{array}$ \\
\hline \multicolumn{6}{|l|}{ Boundary Group: } \\
\hline $\begin{array}{l}\text { Arco } \\
\text { Atomic City } \\
\text { Howe } \\
\text { Monteview } \\
\text { Mud Lake } \\
\text { Reno Ranch }\end{array}$ & $\begin{array}{r}114 \pm 4 \\
121 \pm 4 \\
-f_{f}^{f} \\
110 \pm 4 \\
121 \pm 6 \\
110 \pm 4 \\
115 \pm 7\end{array}$ & $\begin{array}{l}123 \pm 9 \\
117 \pm 9 \\
114 \pm 8 \\
128 \pm 4 \\
124 \pm 6 \\
120 \pm 8 \\
121 \pm 5\end{array}$ & $\begin{array}{l}134 \pm 6 \\
132 \pm 5 \\
126 \pm 4 \\
120 \pm 5 \\
138 \pm 4 \\
\frac{112 \pm 4}{127 \pm 10}\end{array}$ & $\begin{array}{l}117 \pm 4 \\
125 \pm 4 \\
114 \pm 4 \\
116 \pm 4 \\
126 \pm 4 \\
107 \pm 4 \\
118 \pm 7\end{array}$ & $\begin{array}{l}127 \pm 6 \\
134 \pm 8 \\
121 \pm 4 \\
120 \pm 7 \\
130 \pm 8 \\
126 \pm 11 \\
126 \pm 2\end{array}$ \\
\hline $\begin{array}{ll} & \text { Annual exposure } \pm 2 \mathrm{~s} \\
& \text { Dosimeter missing at Nove } \\
& \text { May to November dosimete } \\
& \text { Dosimeter missing at May } \\
& \text { Arithmetic mean with the } 9 \\
& \text { Dosimeter missing at May }\end{array}$ & $\begin{array}{l}\text { ar } 1992 \text { coll } \\
\text { amaged. } \\
\text { November } \\
\text { confidence } \\
0 \text { collection }\end{array}$ & ction times. & & & \\
\hline
\end{tabular}

approximately $1500 \mathrm{~m}$ (4900 ft). The sum of the estimated terrestrial and cosmic components for 1994 is 112 mrem, which is lower than the 130 mrem measured by TLDs at distant locations.

The component of natural background dose that varies the most is that of inhaled radionuclides. According to the National Council on Radiation Protection, the major radionuclides contributing to this component are short-lived decay products of radon, and the amount of radon in buildings and ground water depends, in part, upon the natural radionuclide content of the soil and rock of the area. There is also variation between buildings of a given geographic area depending upon the materials each contains, the amount of ventilation and air movement, and other factors. The U.S. average of 200 mrem has been used in Table 4.10 for this component of the total background dose 
because no specific estimate for southeastern Idaho has been made, and measurements in homes in this area are few. Therefore, the effective dose equivalent from natural background radiation for residents in the INEL vicinity may actually be higher or lower than the total estimated natural background dose of about 350 mrem shown in Table 4.10 and will vary from one location to another.

Annual exposure \pm two standard deviations (2s) for onsite TLDs representing the same exposure period as the offsite dosimeters are shown in Figures 4.9 through 4.18. Onsite dosimeters were placed on facility perimeters, concentrated in areas likely to show the highest gamma radiation readings. At TRA, for example, dosimeters \#3, \#4, and \#5 are adjacent to the former radioactive disposal pond which has been drained and covered by clean soil.

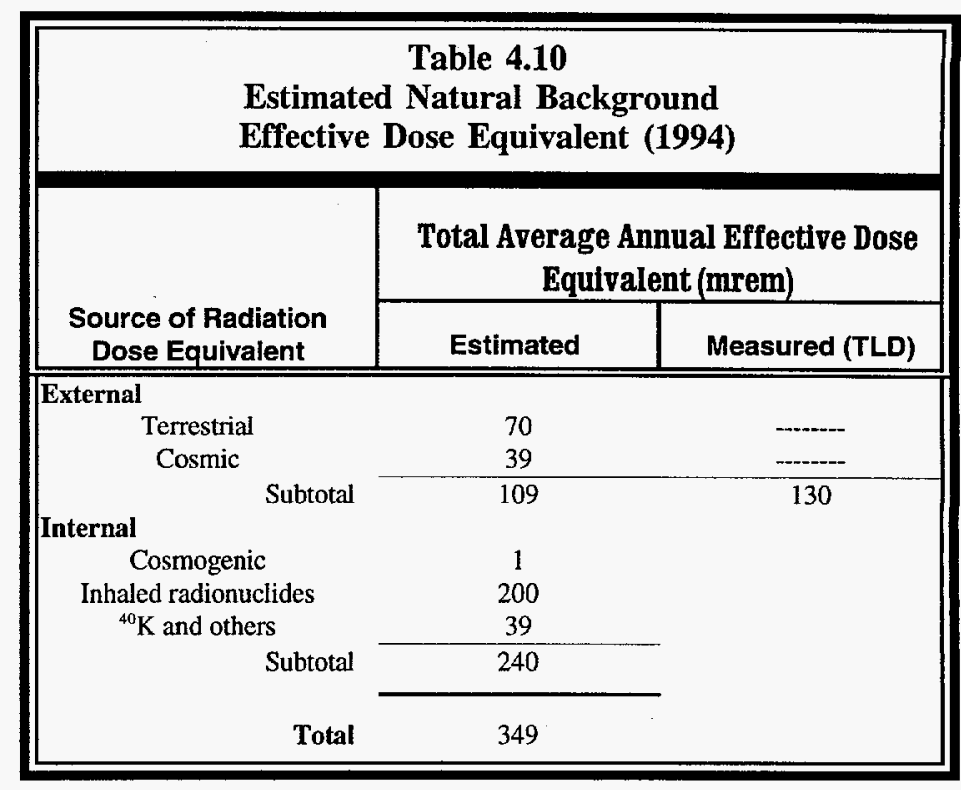

Other dosimeters (e.g., ICPP \#20 through \#22, TRA \#7 and \#8, and ANL-W \#15) are located in the vicinity of radioactive material storage areas. At some facilities, particularly ARA and ICPP, slightly elevated exposures result from soil contamination. 


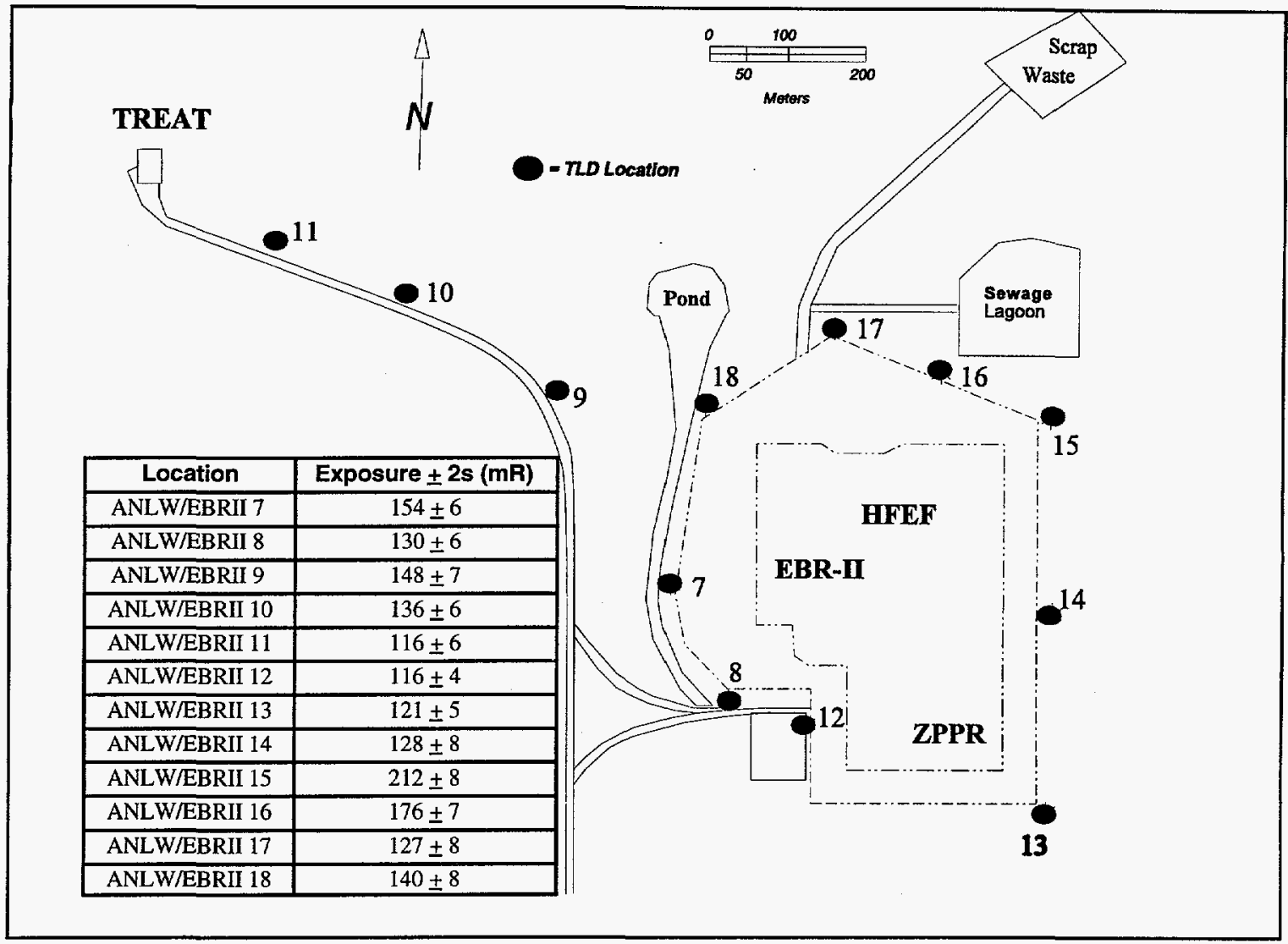

Figure 4.9 Environmental Dosimeter Measurements at ANL-W (1994)

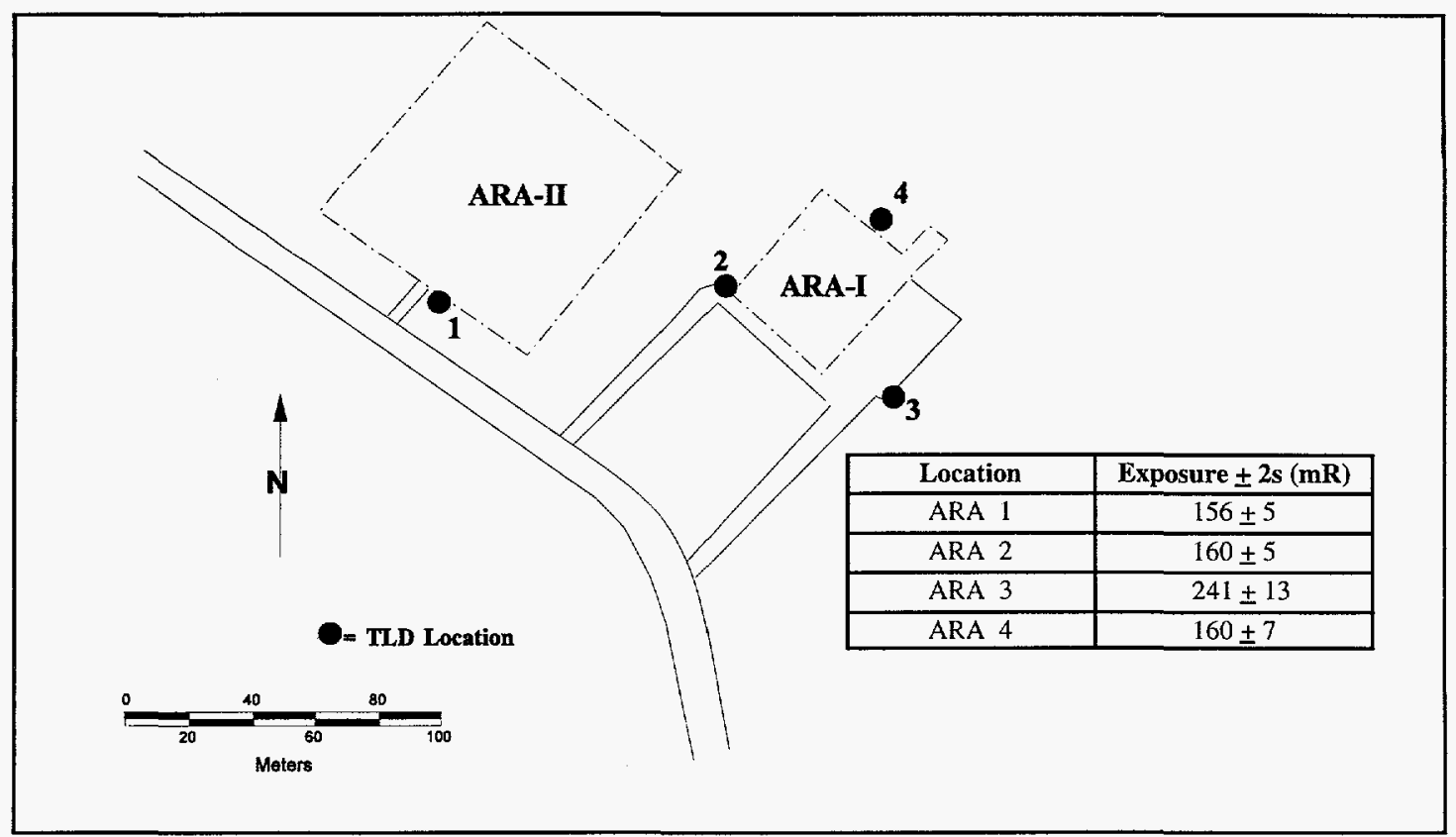

Figure 4.10 Environmental Dosimeter Measurements at ARA (1994) 
4. Environmental Radiological Program Information

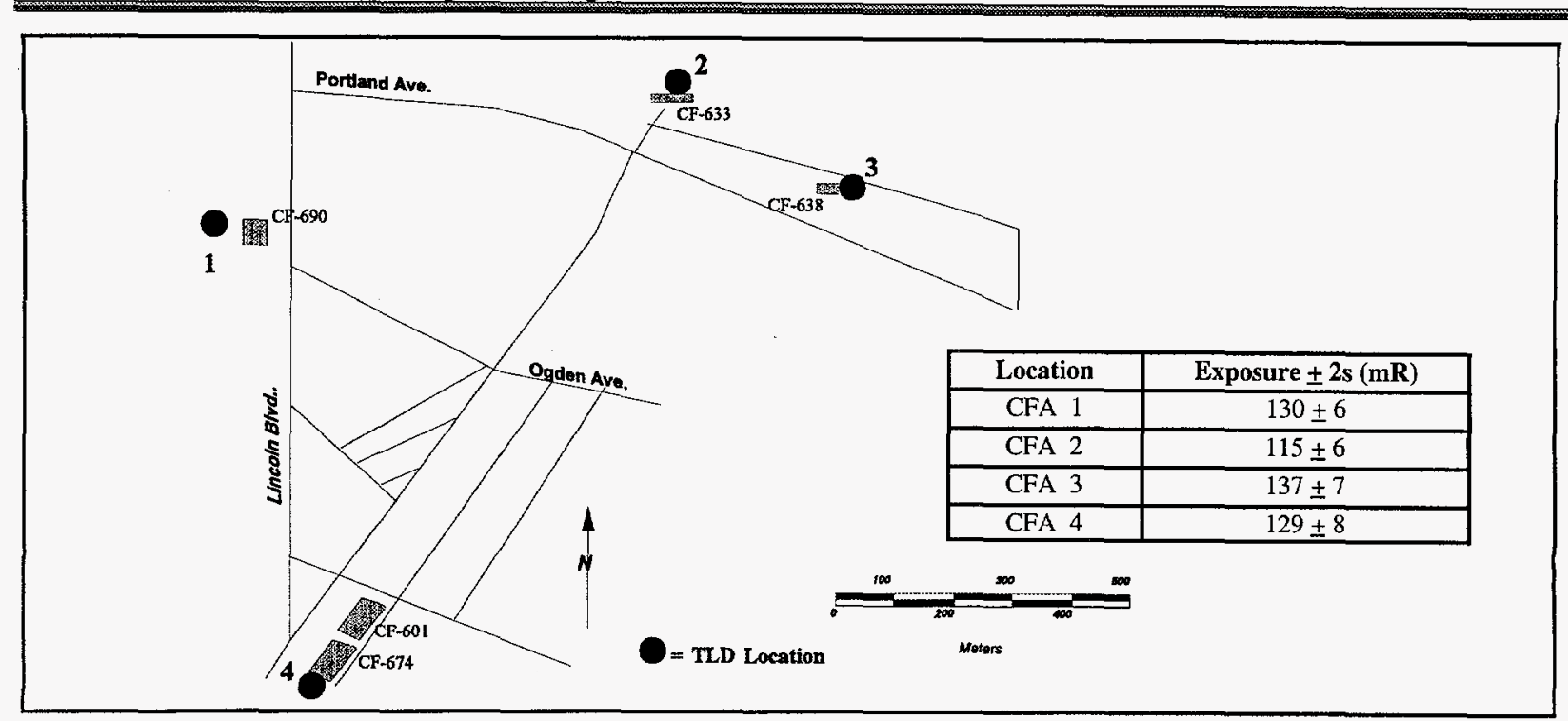

Figure 4.11 Environmental Dosimeter Measurements at CFA (1994)

\begin{tabular}{|c|c|}
\hline Location & Exposure $\pm \mathbf{2 s}(\mathbf{m R})$ \\
\hline ICPP 1 & $165 \pm 7$ \\
\hline ICPP 9 & $202 \pm 8$ \\
\hline ICPP 14 & $149 \pm 6$ \\
\hline ICPP 15 & $152 \pm 7$ \\
\hline ICPP 16 & $141 \pm 10$ \\
\hline ICPP 17 & $138 \pm 6$ \\
\hline ICPP 18 & $139 \pm 6$ \\
\hline ICPP 19 & $133 \pm 7$ \\
\hline ICPP 20 & $217 \pm 9$ \\
\hline ICPP 21 & $162 \pm 7$ \\
\hline ICPP 22 & $205 \pm 8$ \\
\hline ICPP 23 & $157 \pm 13$ \\
\hline ICPP 24 & $132 \pm 4$ \\
\hline ICPP 25 & $125 \pm 5$ \\
\hline ICPP 26 & $128 \pm 5$ \\
\hline
\end{tabular}

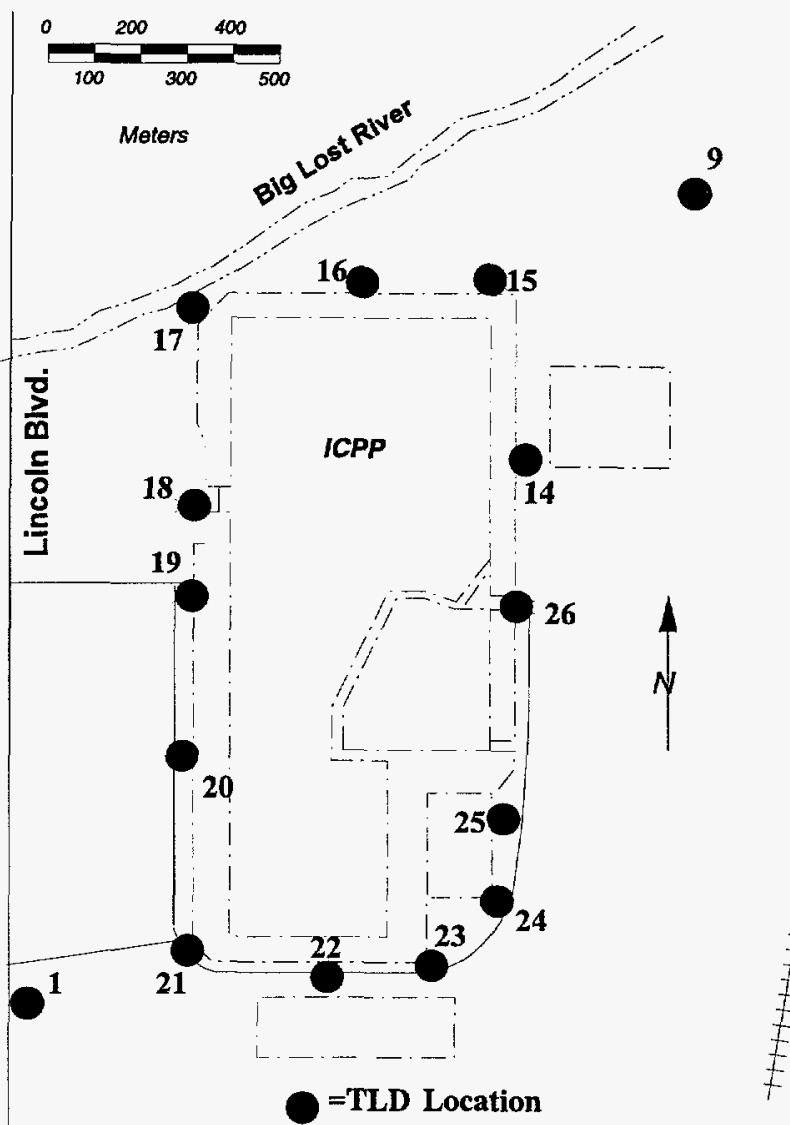

Figure 4.12 Environmental Dosimeter Measurements at ICPP (1994) 


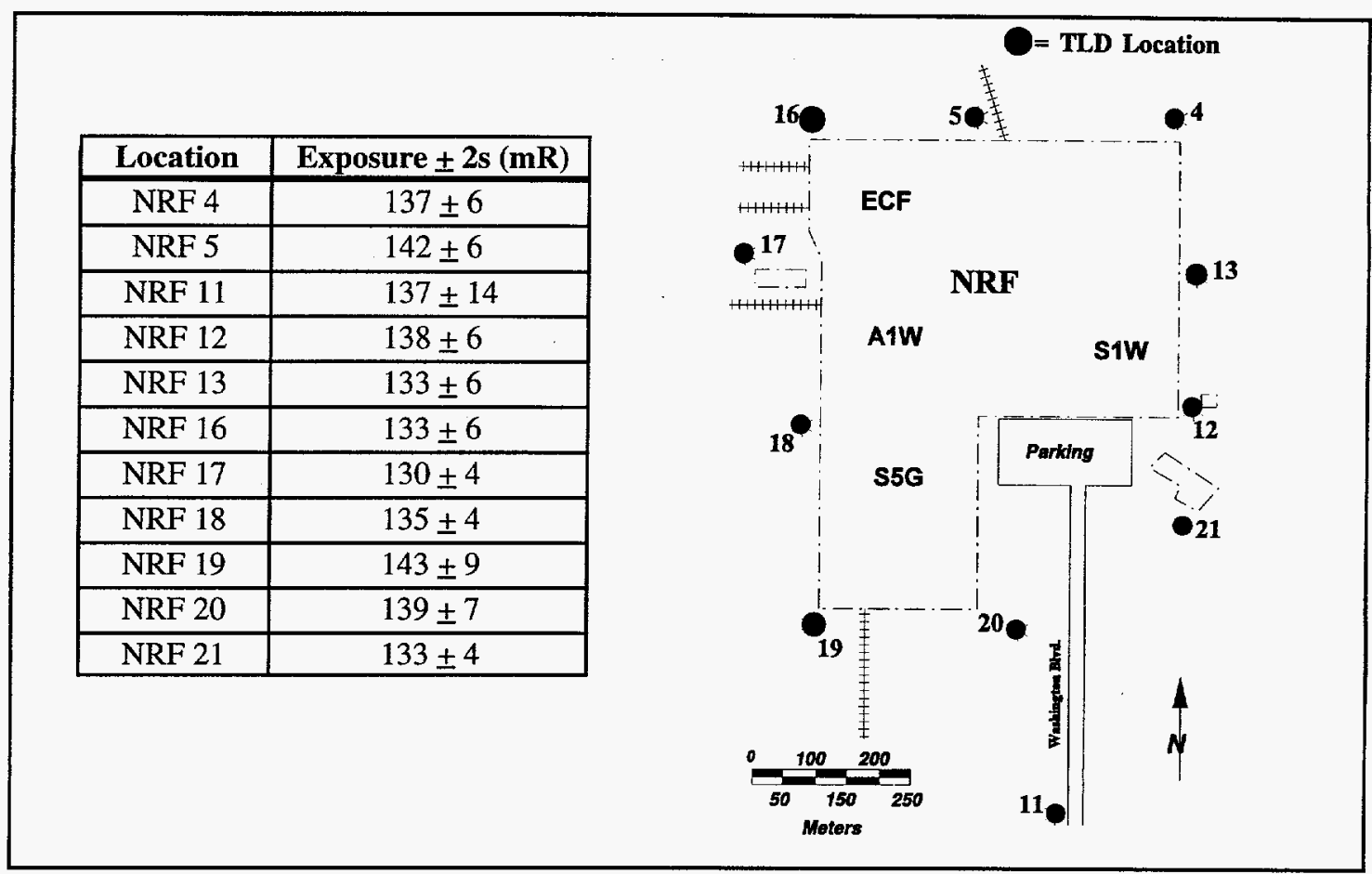

Figure 4.13 Environmental Dosimeter Measurements at NRF (1994)

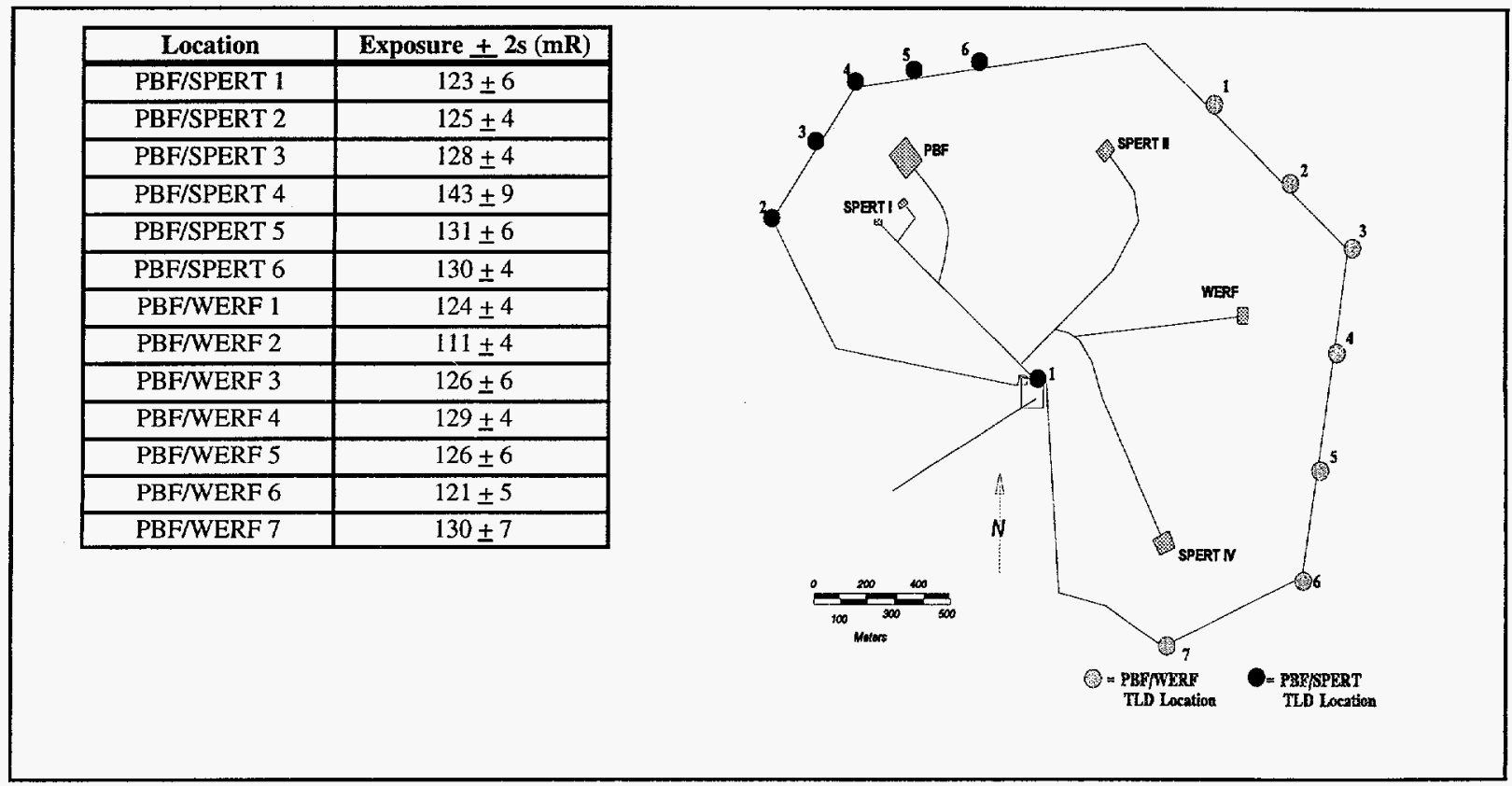

Figure 4.14 Environmental Dosimeter Measurements at PBF (1994) 


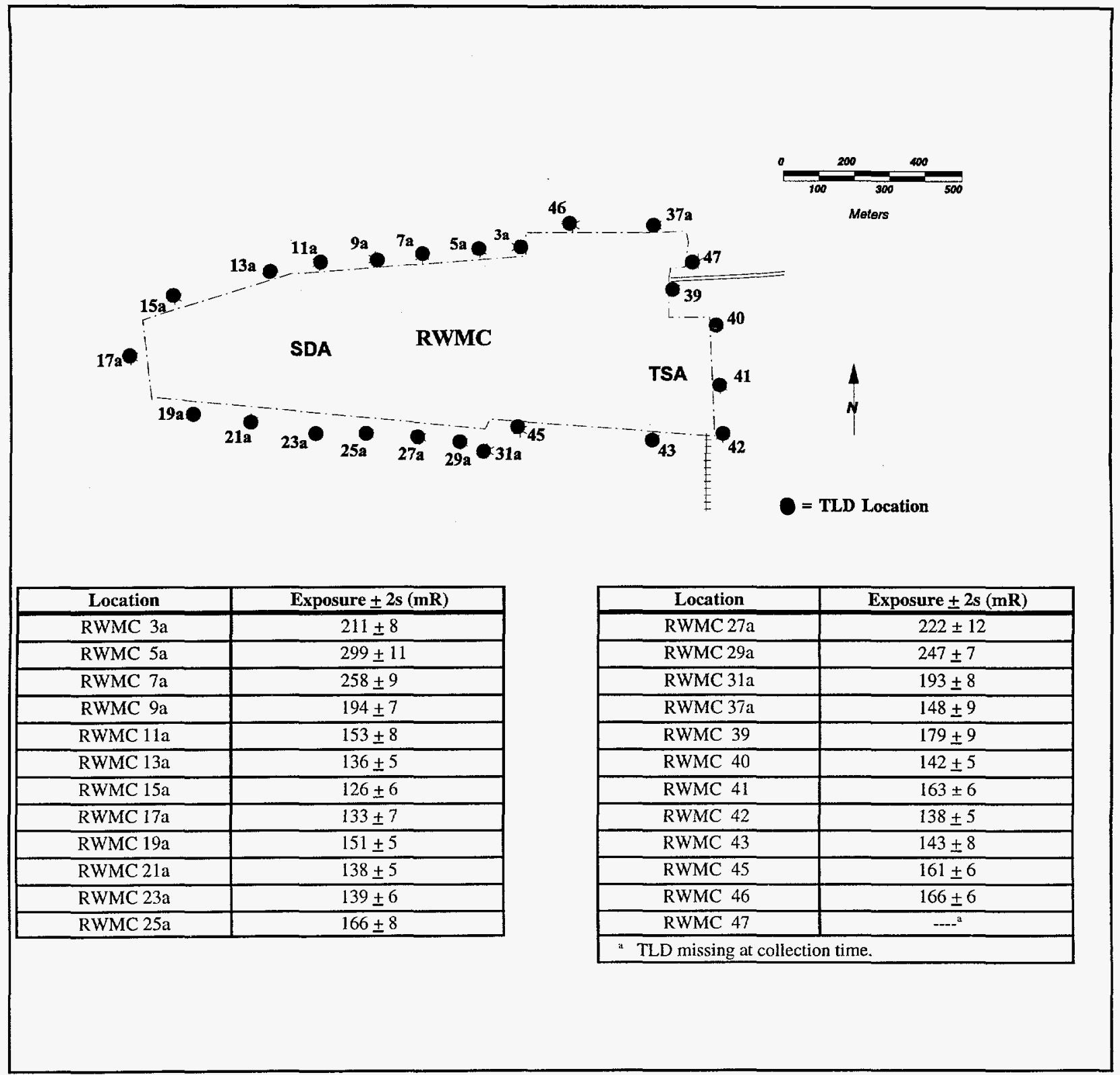

Figure 4.15 Environmental Dosimeter Measurements at RWMC (1994) 


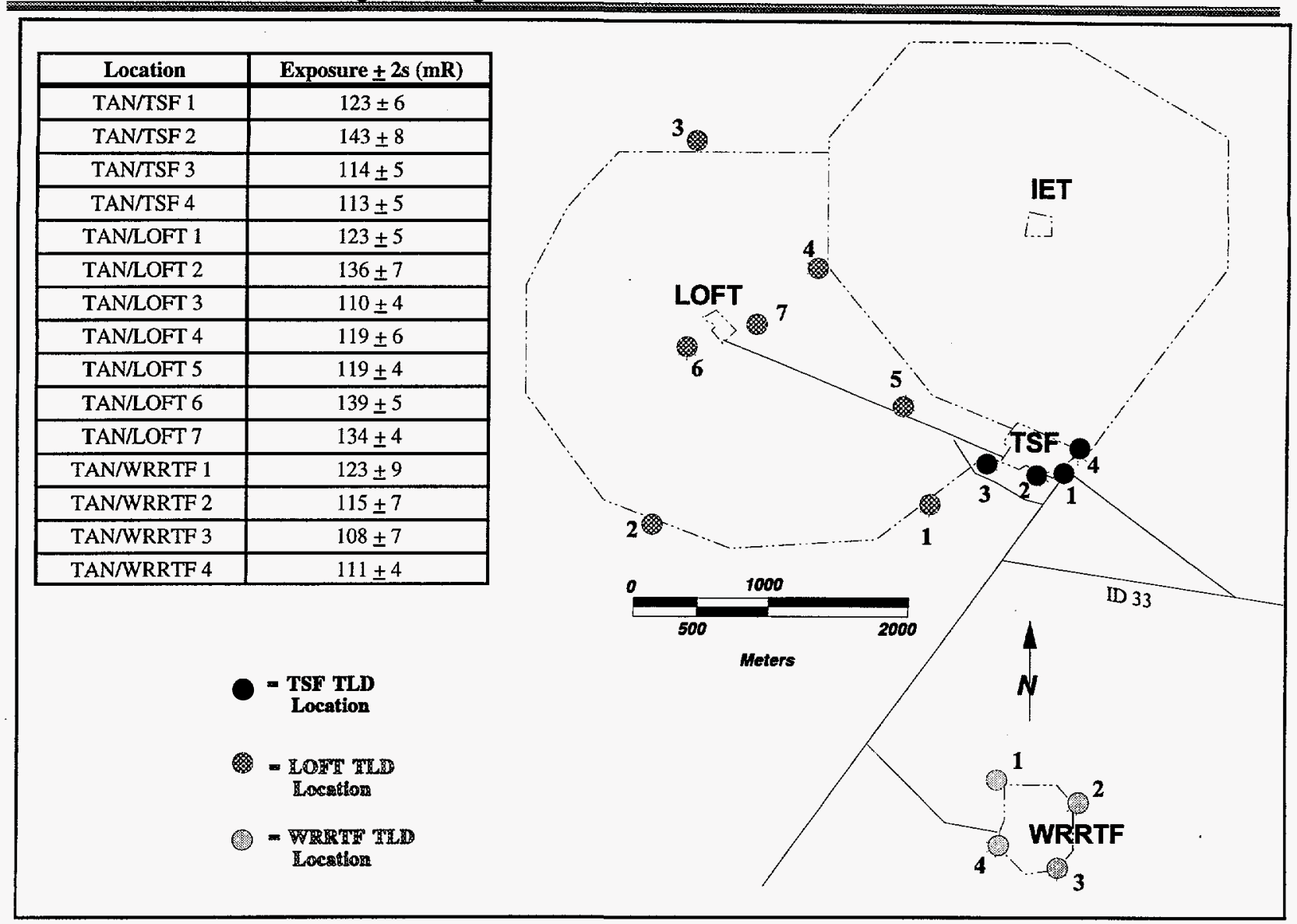

Figure 4.16 Environmental dosimeter measurements at TAN (1994)

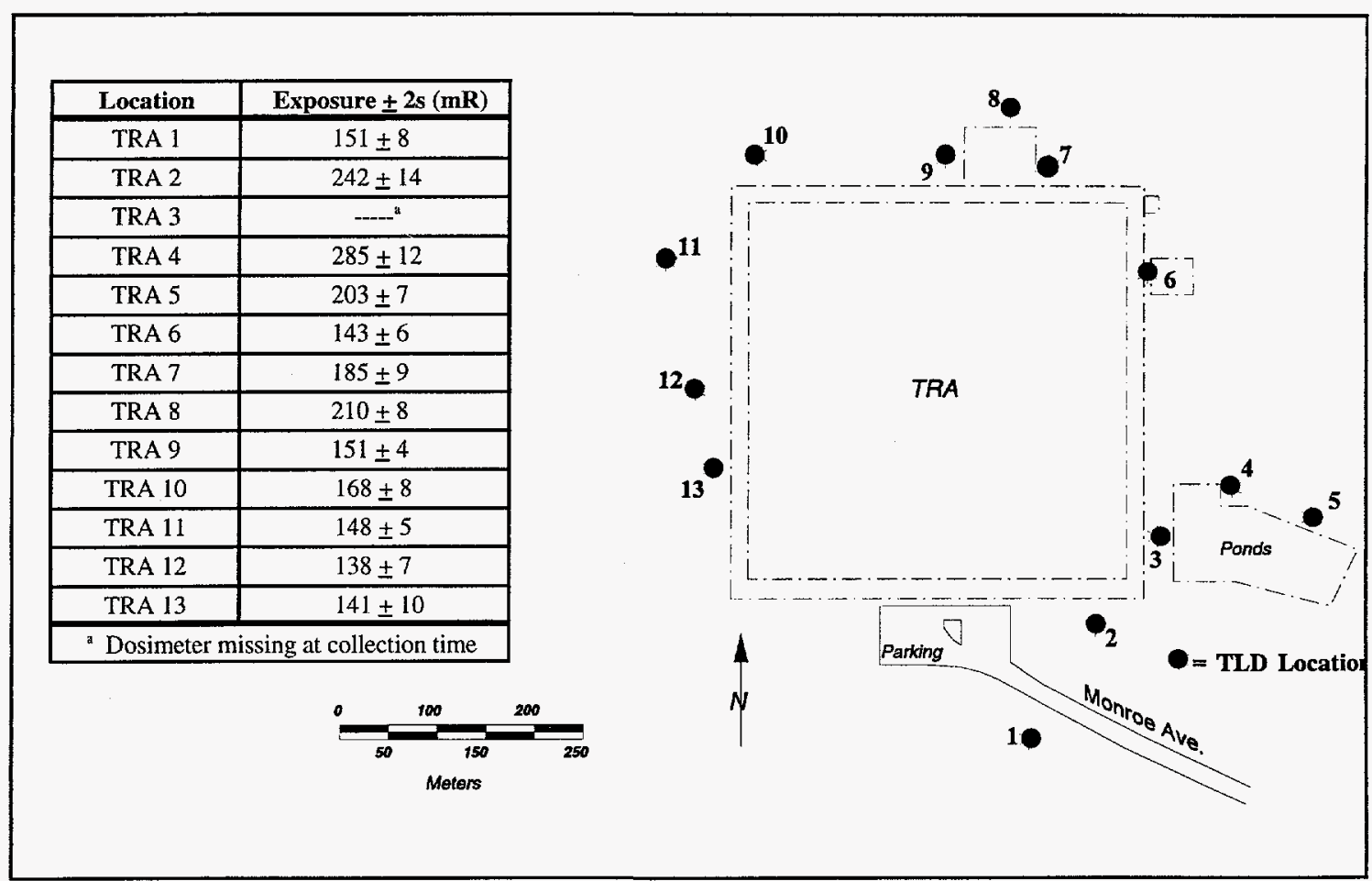

Figure 4.17 Environmental Dosimeter Measurements at TRA (1994) 

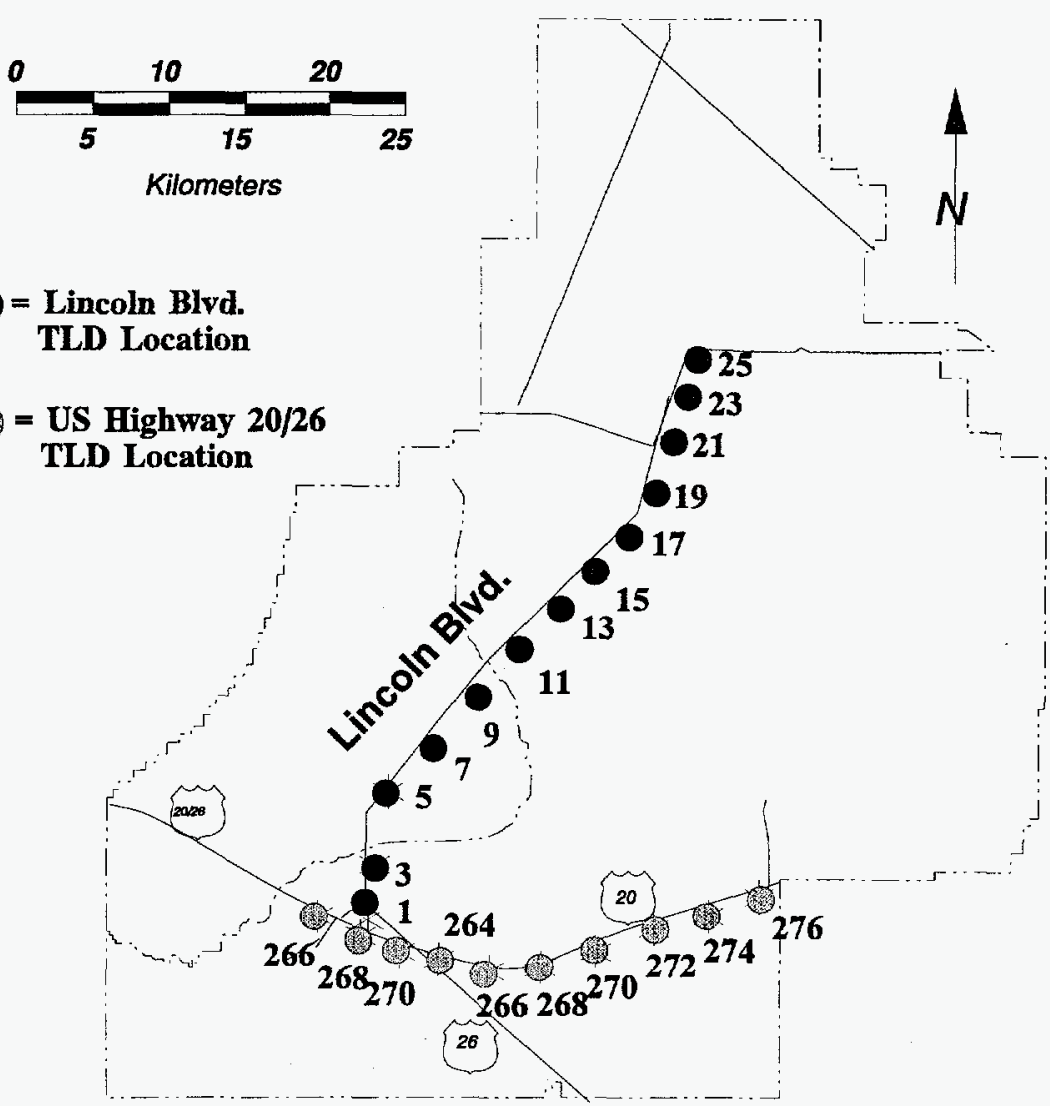

\begin{tabular}{|c|c|}
\hline Location & Exposure \pm 2 s (mR) \\
\hline LINCOLN BLVD. 1 & $125 \pm 7$ \\
\hline LINCOLN BLVD. 3 & $161 \pm 6$ \\
\hline LINCOLN BLVD. 5 & $141 \pm 6$ \\
\hline LINCOLN BLVD. 7 & $131 \pm 6$ \\
\hline LINCOLN BLVD. 9 & $135 \pm 4$ \\
\hline LINCOLN BLVD. 11 & $134 \pm 4$ \\
\hline LINCOLN BLVD. 13 & $133 \pm 5$ \\
\hline LINCOLN BLVD. 15 & $137 \pm 6$ \\
\hline LINCOLN BLVD. 17 & $139 \pm 6$ \\
\hline LINCOLN BLVD. 19 & $129 \pm 4$ \\
\hline LINCOLN BLVD. 21 & $126 \pm 5$ \\
\hline LINCOLN BLVD. 23 & $--^{2}$ \\
\hline LINCOLN BLVD. 25 & $125 \pm 6$ \\
\hline \multicolumn{2}{|c|}{${ }^{2}$ Dosimeter missing at collection time } \\
\hline
\end{tabular}

\begin{tabular}{|c|c|}
\hline Location & Exposure \pm 2 s (mR) \\
\hline HIGHWAY 26 mile 266 & $139 \pm 8$ \\
\hline HIGHWAY 26 mile 268 & $\cdots--^{2}$ \\
\hline HIGHWAY 26 mile 270 & $130 \pm 6$ \\
\hline HIGHWAY 20 mile 264 & $125 \pm 5$ \\
\hline HIGHWAY 20 mile 266 & $116 \pm 4$ \\
\hline HIGHWAY 20 mile 268 & $123 \pm 6$ \\
\hline HIGHWAY 20 mile 270 & $116 \pm 6$ \\
\hline HIGHWAY 20 mile 272 & $\cdots-{ }^{4}$ \\
\hline HIGHWAY 20 mile 274 & $102 \pm 4$ \\
\hline HIGHWAY 20 mile 276 & $118 \pm 4$ \\
\hline \multicolumn{2}{|c}{ Dosimeter missing at collection time } \\
\hline
\end{tabular}

Figure 4.18 Environmental Dosimeter Measurements along Lincoln Blvd. and US Highways 20 and 26 (1994) 


\subsection{RADIOACTIVE EFFLUENT MONITORING}

\section{General}

Radionuclides in airborne and liquid effluents released to the environment were monitored at potentially significant release points. INEL contractors monitored these release points, including stacks and liquid effluent streams at facilities they operated, as required by state and federal regulations. These data were reported to EG\&G/LITCO's Radioactive Waste Management Information System, which published quarterly reports of the results of the effluent monitoring by month, facility, and radionuclide.

\section{Air}

An estimated total of $2300 \mathrm{Ci}$ of radioactivity was released to the atmosphere from INEL facilities in 1994 (Table 4.11). More than $95 \%$ of this total was in the form of noble gases. The ANL-W and TRA facilities were the source of nearly all of the radioactivity released to the atmosphere. Because of radioactive decay of the short-lived radionuclides, the actual activity that would reach offsite areas is less than the values indicated in the table.

The annual total airborne radioactive effluent varies from year to year, depending on which processes are active at INEL facilities. The total shown for 1994 is considerably less than the totals reported for the years 1987 through 1992. In those years, the actual amount of ${ }^{85} \mathrm{Kr}$ released from ICPP was classified information and an overestimated value was used. This was no longer the case beginning in 1993. Due to this overestimation of the ${ }^{85} \mathrm{Kr}$ release value, it is not possible to directly compare total amounts of radioactivity released to the air for years prior to 1993 . The $2300 \mathrm{Ci}$ reported for 1994 was reduced from the $2800 \mathrm{Ci}$ value in 1993.

\section{Liquid}

No liquids were released directly to the offsite environment. Onsite releases are summarized in Table 4.12. No radioactive liquids were released onsite at NRF. Most liquid radioactive effluents were discharged into seepage ponds. At TRA, a new liquid effluent pond lined with hypalon plastic was constructed and placed in service in August 1993. This pond was used throughout calendar year 1994.

\subsection{EVALUATION OF POTENTIAL RADIATION DOSE TO THE PUBLIC}

\section{General Information}

Usually, the radiological impact of INEL operations on the resident public surrounding the INEL has been too small to be measured by the routine monitoring program. Therefore, the radiological impact of INEL operations by the air pathway has traditionally been estimated using the reported amounts of various radionuclides released during the year from Site facilities and appropriate air dispersion models, described in the next section, to determine the concentrations at selected locations in the vicinity. During 1994, this was done for the radionuclides summarized in Table 4.11. The following were calculated: 1) the effective dose equivalent to the maximally exposed individual residing offsite using the EPA-required CAP-88 model; 2) the effective dose equivalent to the maximally exposed individual residing offsite using dispersion 


\begin{tabular}{|c|c|c|c|c|c|c|c|}
\hline \multicolumn{8}{|c|}{$\begin{array}{c}\text { TABLE 4.11 } \\
\text { RADIONUCLIDE COMPOSITION OF AIRBORNE EFFLUENTS (1994) }\end{array}$} \\
\hline \multirow{12}{*}{$\begin{array}{l}\text { Effluent } \\
\text { Type } \\
\text { Noble Gases }\end{array}$} & \multirow{2}{*}{$\begin{array}{l}\text { Radio- } \\
\text { nuclide }\end{array}$} & \multirow[b]{2}{*}{ Half-life } & \multicolumn{5}{|c|}{ Airborne Effluent (Curies) ${ }^{a}$} \\
\hline & & & ANL-W & $\underline{\text { ICPP }}$ & NRF & IRA & Total \\
\hline & ${ }^{41} \mathrm{Ar}$ & $1.83 \mathrm{~h}$ & 17 & -- & $\overline{0.17}$ & 1010 & 1030 \\
\hline & ${ }^{133} \mathrm{Xe}$ & $5.25 \mathrm{~d}$ & 420 & -- & -- & 3.7 & 420 \\
\hline & ${ }^{135} \mathrm{Xe}$ & $9.10 \mathrm{~h}$ & 270 & -- & - & 17 & 290 \\
\hline & ${ }^{88} \mathrm{Kr}$ & $2.84 \mathrm{~h}$ & 190 & -- & - & 9.9 & 200 \\
\hline & ${ }^{138} \mathrm{Xe}$ & $14.2 \mathrm{~min}$ & 62 & -- & -- & 16 & 78 \\
\hline & ${ }^{87} \mathrm{Kr}$ & $1.27 \mathrm{~h}$ & 68 & -- & - & 8.4 & 77 \\
\hline & ${ }^{85 \mathrm{~m}} \mathrm{Kr}$ & $4.48 \mathrm{~h}$ & 52 & -- & -- & 3.5 & 57 \\
\hline & ${ }^{135 \mathrm{~m}} \mathrm{Xe}$ & $15.3 \mathrm{~min}$ & 18 & -- & - & 3.5 & 21 \\
\hline & ${ }^{140} \mathrm{Xe}$ & $13.6 \mathrm{sec}$ & 9.4 & -- & -- & -- & 9.4 \\
\hline & ${ }^{85} \mathrm{Kr}$ & $10.7 \mathrm{yr}$ & 5.2 & - & -- & -- & 5.2 \\
\hline \multirow[t]{20}{*}{ Particulates } & ${ }^{140} \mathrm{Cs}$ & $1.06 \mathrm{~min}$ & 9.1 & - & -- & -- & 9.1 \\
\hline & ${ }^{140} \mathrm{La}$ & $40.2 \mathrm{hr}$ & $1.6 \times 10^{-8}$ & -- & - & 4.5 & 4.5 \\
\hline & ${ }^{203} \mathrm{Hg}$ & $46.6 \mathrm{~d}$ & -- & - & -- & 1.4 & 1.4 \\
\hline & ${ }^{88} \mathrm{Rb}$ & $15.4 \mathrm{~min}$ & $4.1 \times 10^{-4}$ & -- & -- & 1.0 & 1.1 \\
\hline & ${ }^{138} \mathrm{Cs}$ & $32.2 \mathrm{~min}$ & -- & -- & -- & 0.16 & 0.16 \\
\hline & ${ }^{89} \mathrm{Rb}$ & $15.4 \mathrm{~min}$ & -- & -- & -- & $6.2 \times 10^{-2}$ & $6.2 \times 10^{-2}$ \\
\hline & ${ }^{22} \mathrm{Na}$ & $2.60 \mathrm{yr}$ & -- & -- & -- & $2.5 \times 10^{-2}$ & $2.5 \times 10^{-2}$ \\
\hline & ${ }^{24} \mathrm{Na}$ & $15.0 \mathrm{~h}$ & -. & -- & -- & $1.8 \times 10^{-2}$ & $1.8 \times 10^{-2}$ \\
\hline & ${ }^{91 \mathrm{~m}} \mathrm{Y}$ & $58.8 \mathrm{~d}$ & -- & -- & -- & $1.6 \times 10^{-2}$ & $1.6 \times 10^{-2}$ \\
\hline & ${ }^{51} \mathrm{Cr}$ & $27.8 \mathrm{~d}$ & -- & -- & -- & $1.1 \times 10^{-2}$ & $1.1 \times 10^{-2}$ \\
\hline & ${ }^{139} \mathrm{Ba}$ & $1.39 \mathrm{~h}$ & -- & -- & -- & $1.1 \times 10^{-2}$ & $1.1 \times 10^{-2}$ \\
\hline & ${ }^{99 \mathrm{~m}} \mathrm{Tc}$ & $6.01 \mathrm{~h}$ & - & -- & -- & $8.8 \times 10^{-3}$ & $8.8 \times 10^{-3}$ \\
\hline & ${ }^{187} W$ & $23.9 \mathrm{~h}$ & -- & -- & -- & $2.5 \times 10^{-3}$ & $2.5 \times 10^{-3}$ \\
\hline & ${ }^{92} \mathrm{Sr}$ & $2.71 \mathrm{~h}$ & -- & -- & -- & $2.0 \times 10^{-3}$ & $2.0 \times 10^{-3}$ \\
\hline & ${ }^{137} \mathrm{Cs}$ & $30.2 \mathrm{yr}$ & $3.2 \times 10^{-7}$ & $1.5 \times 10^{-3}$ & -- & $2.4 \times 10^{-5}$ & $1.5 \times 10^{-3}$ \\
\hline & ${ }^{92} \mathrm{Y}$ & $3.54 \mathrm{~h}$ & -- & -- & -- & $1.5 \times 10^{-3}$ & $1.5 \times 10^{-3}$ \\
\hline & ${ }^{91} \mathrm{Sr}$ & $9.52 \mathrm{~h}$ & -- & -- & -- & $1.5 \times 10^{-3}$ & $1.5 \times 10^{-3}$ \\
\hline & ${ }^{90} \mathrm{Sr}+\mathrm{D}^{\mathrm{c}}$ & $28.6 \mathrm{yr}$ & -- & $9.4 \times 10^{-4}$ & -- & $4.6 \times 10^{-5}$ & $9.9 \times 10^{-4}$ \\
\hline & ${ }^{125} \mathrm{Sb}$ & $2.73 \mathrm{yr}$ & -- & $3.2 \times 10^{-5}$ & -- & -- & $3.2 \times 10^{-5}$ \\
\hline & $\mathrm{Pu}$ (total) & -- & -- & $5.7 \times 10^{-7}$ & -- & -- & $5.7 \times 10^{-7}$ \\
\hline \multirow{8}{*}{$\begin{array}{l}\text { Tritium, }{ }^{14} \mathrm{C} \text {, } \\
\text { and lodine } \\
\text { Isotopes }\end{array}$} & ${ }^{3} \mathrm{H}$ & $12.3 \mathrm{yr}$ & 33 & 0.12 & $2.9 \times 10^{-2}$ & -- & 33 \\
\hline & ${ }^{14} \mathrm{C}$ & $5700 \mathrm{yr}$ & -- & -- & 0.50 & -- & 0.50 \\
\hline & ${ }^{134} \mathrm{I}$ & $52.6 \mathrm{~min}$ & - & -- & -- & $4.3 \times 10^{-3}$ & $4.3 \times 10^{-3}$ \\
\hline & ${ }^{135} \mathrm{I}$ & $6.59 \mathrm{hr}$ & -- & -- & -- & $3.7 \times 10^{-3}$ & $3.7 \times 10^{-3}$ \\
\hline & ${ }^{129} \mathrm{I}$ & $1.6 \times 10^{7} \mathrm{yr}$ & -- & $3.0 \times 10^{-3}$ & - & -- & $3.0 \times 10^{-3}$ \\
\hline & ${ }^{132} \mathrm{I}$ & $83 \mathrm{~min}$ & -- & -- &.- & $2.2 \times 10^{-3}$ & $2.2 \times 10^{-3}$ \\
\hline & ${ }^{133} \mathrm{I}$ & $20.8 \mathrm{hr}$ & -- & - & -- & $2.1 \times 10^{-3}$ & $2.1 \times 10^{-3}$ \\
\hline & ${ }^{131} \mathrm{I}$ & $8.04 \mathrm{~d}$ & -- & -- & $1.7 \times 10^{-6}$ & $3.8 \times 10^{-4}$ & $3.8 \times 10^{-4}$ \\
\hline \multirow{2}{*}{\multicolumn{2}{|c|}{$\begin{array}{l}\text { All others } \\
\text { Totals }\end{array}$}} & -- & 2.5 & $4.7 \times 10^{-4}$ & $1.2 \times 10^{-5}$ & $2.8 \times 10^{-3}$ & 2.5 \\
\hline & & - & 1200 & 0.13 & 0.70 & 1100 & 2300 \\
\hline \multicolumn{8}{|c|}{$\begin{array}{l}\text { Preliminary radioactive release information provided by the } 1994 \text { Radioactive Waste Management Information System. The table } \\
\text { includes all radionuclides with total releases greater than } 1 \times 10^{-3} \mathrm{Ci}\left(1 \times 10^{-4} \text { for isotopes of iodine). Some radionuclides of special }\right. \\
\text { concern }\left({ }^{125} \mathrm{Sb},{ }^{91} \mathrm{Sr} \text {, and } \mathrm{Pu}\right) \text { are also included. Values are not corrected for decay after release. } \\
\text { Totals include small amounts from facilities not listed. } \\
\text { Parent-daughter equilibrium assumed. }\end{array}$} \\
\hline
\end{tabular}




\begin{tabular}{|c|c|c|c|c|c|}
\hline \multicolumn{6}{|c|}{$\begin{array}{c}\text { TABLE } 4.12 \\
\text { RADIONUCLIDE COMPOSITION OF LIQUID EFFLUENTS } \\
\text { RELEASED ONSITE (1994) }\end{array}$} \\
\hline \multirow[b]{2}{*}{ Radionuclide } & \multirow[b]{2}{*}{ Half-Life } & \multicolumn{4}{|c|}{ Liquid Effluent (Curies) } \\
\hline & & ANL-W & ICPP & IRA & Total $^{b}$ \\
\hline${ }^{3} \mathrm{H}$ & $12.3 \mathrm{yr}$ & $4.6 \times 10^{-2}$ & - & $\overline{47}$ & 47 \\
\hline${ }^{51} \mathrm{Cr}$ & $27.8 \mathrm{~d}$ & -- & -- & 1.9 & 1.9 \\
\hline${ }^{89} \mathrm{Sr}$ & $50.5 d$ & -- & -- & 0.58 & 0.58 \\
\hline${ }^{60} \mathrm{Co}$ & $5.26 \mathrm{yr}$ & -- & $1.1 \times 10^{-4}$ & 0.56 & 0.56 \\
\hline${ }^{90} \mathrm{Sr}+\mathrm{D}^{\mathrm{c}}$ & $28.6 \mathrm{yr}$ & -- & $9.4 \times 10^{-4}$ & 0.18 & 0.18 \\
\hline${ }^{137} \mathrm{Cs}$ & $30.2 \mathrm{yr}$ & $1.3 \times 10^{-7}$ & $3.7 \times 10^{-4}$ & 0.11 & 0.11 \\
\hline${ }^{24} \mathrm{Na}$ & $15.0 \mathrm{yr}$ & -- & -- & $1.7 \times 10^{-2}$ & $1.7 \times 10^{-2}$ \\
\hline All Others & -- & -- & $4.3 \times 10^{-4}$ & 0.37 & 0.37 \\
\hline Grand Totals & -- & $4.6 \times 10^{-2}$ & $5.7 \times 10^{-3}$ & 51 & 51 \\
\hline \multicolumn{6}{|c|}{$\begin{array}{l}\text { Preliminary radioactive release data provided by the } 1994 \text { Radioactive Waste Management Information System. } \\
\text { Table includes all radionuclides with total releases greater than } 1 \times 10^{-2} \mathrm{Ci} \text {. Values are not corrected for decay after } \\
\text { release. } \\
\text { Total includes small amounts from facilities not listed. } \\
\text { Parent/daughter equilibrium assumed. }\end{array}$} \\
\hline
\end{tabular}

calculations from the MESODIF model ${ }^{\mathrm{a}}$; and 3) the collective effective dose equivalent (population dose) within an $80-\mathrm{km}(50-\mathrm{mi}) \mathrm{ra}-$ dius of the operations center of the Site (TRA and ICPP) using the MESODIF dispersion model.

For simplicity, the term dose will mean effective dose equivalent in the following dose assessment sections, unless another term is specifically stated. The dose was calculated by summing the committed dose equivalents to organs, each multiplied by a weighting factor that is proportional to the organ's radiosensitivity. The effective dose equivalent includes doses received from both external and internal sources and represents the same risk as if an individual's whole body were irradiated uniformly. DOE dose conversion

a G.E. Start and L.L. Wendell, Regional Effluent Dispersion Calculations Considering Spatial and Temporal Meteorological Variations; NOAA Technical Memorandum ERL ARL-44, May 1974. factors and a 50-yr integration period are used for internally deposited radionuclides ${ }^{b}$ and for radionuclides deposited on ground surfaces ${ }^{\mathrm{c}}$ in calculations with both air dispersion models. Because the hypothetical effective dose equivalent to the maximally exposed individual residing near the $\mathrm{INEL}$ is so low, no allowance was made for shielding by housing materials or residence time in the community in any of the calculations using the MESODIF dispersion model. The CAP- 88 code, which is used by all sites regardless of the magnitude of the hypothetical dose, does include a factor to allow for shielding and occupancy time.

The possible exposure pathways by which radioactive materials from Site operations could be transported to offsite environs were

\footnotetext{
' U.S. Department of Energy, Internal Dose Conversion Factors for Calculation of Dose to the Public, DOE/EH-0071, July 1988.

' U.S. Department of Energy, External Dose Conversion Factors for Calculation of Dose to the Public, DOE/EH-0070, July 1988.
} 
shown diagrammatically in Figure 3.1. Atmospheric transport is the principal potential exposure pathway from the INEL because radionuclides from the INEL have not been found in drinking water wells offsite. The air pathway is evaluated in the section "Maximum Individual Dose--Airborne Emissions Pathway".

Several indirect exposure pathways are being studied at the INEL to determine their effect, if any, on the highest possible dose that could have been received by a member of the public. The principal indirect exposure pathway involves eating game animals that have spent time on the INEL. Radioactivity present in game species depends upon the length of residence at each onsite location, the time elapsed since migration from the Site, and the metabolism of the animal. Estimates of the maximum potential dose to a person consuming meat from different game animals is described in the section "Maximum Individual Dose--Game Ingestion Pathway."

\section{Maximum Individual Dose--Airborne Emissions Pathway}

CAP-88. During 1994, EPA regulations were in effect that limited the amount of airborne radionuclides released from any nuclear facility to that which will produce an effective dose equivalent of $10 \mathrm{mrem} / \mathrm{yr}$ to any member of the public. These regulations, known as the National Emission Standards for Hazardous Air Pollutants (NESHAPs), are found in 40 CFR Part 61 [Subpart H]. The EPA has specified that the CAP- 88 computer code be used to demonstrate compliance unless an alternate model has been approved by the Administrator of the EPA.
Because the INEL operations are spread over a wide area, the potential offsite doses occur at a variety of receptor (nearest resident, school, or business) locations. For the NESHAPs report, the offsite dose was calculated for the nearest resident to each INEL facility that reported airborne releases in 1994. The doses from all facilities were then summed. This method is conservative (it overestimates the dose) because the maximum exposed individual was assumed to live at all of these maximum receptor locations simultaneously. Using the CAP-88 code and INEL facility emissions, a 1994 hypothetical effective dose equivalent of $0.004 \mathrm{mrem}$ $\left(4 \times 10^{-5} \mathrm{mSv}\right)$ was calculated for a member of the public. This dose is $0.04 \%$ of the EPA radiation protection standard. A thorough discussion of the NESHAPs calculations will appear in the 1994 INEL NESHAPs annual report to be submitted to the EPA by June 30 , 1995.

The CAP-88 calculation included evaluation of air emissions from nonpoint, or diffuse, sources such as radioactive waste ponds (TRA and ICPP) and known contaminated soil areas on the INEL. The total of the doses from these nonpoint sources for 1994 was $1.3 \times 10^{-5} \mathrm{mrem}\left(1.3 \times 10^{-7}\right.$ $\mathrm{mSv}$ ). Of this total, TRA was the largest contributor with $8.6 \times 10^{-6}$ mrem $\left(8.6 \times 10^{-8}\right.$ $\mathrm{mSv})$.

MESODIF. The MESODIF air dispersion model has been used for 20 years to calculate doses to members of the public residing near the INEL. The MESODIF diffusion curves, developed from tests in the desert environments at the INEL and Hanford facility in the state of Washington, appear to be more 
appropriate for the INEL than the EPArequired model. MESODIF uses a more complicated Gaussian puff model than the straight-line Gaussian plume model in CAP88. The doses calculated with the MESODIF model are usually somewhat higher than doses using CAP-88. The doses and offsite concentrations calculated using both models were compared to actual monitoring results at offsite locations in 1986, 1987, and 1988. Concentrations and doses calculated for several locations using the MESODIF model showed good agreement with concentrations from actual measurements. Differences between the two air dispersion models were discussed in detail in the 1986 annual report. ${ }^{a}$ The effective dose equivalent calculated using the MESODIF model is included in this report as well as the value calculated using the EPArequired CAP-88 model.

The mesoscale map (Figure 4.19) shows the calculated 1994 concentrations normalized to a unit release rate for the INEL and vicinity. This map was prepared by the National Oceanic and Atmospheric Administration's Air Resources Laboratory using the MESODIF model and data gathered continuously at meteorological stations on and around the Site. To make the display easier to read, the dispersion coefficient values are given in whole numbers and must be multiplied by $10^{-9}$ $\mathrm{h}^{2} / \mathrm{m}^{3}$. To obtain the average air concentration $\left(\mathrm{Ci} / \mathrm{m}^{3}\right)$ for a radionuclide released from TRA or ICPP along any dispersion coefficient isopleth in Figure 4.19, the value of the 1994 average dispersion coefficient (e.g., $30 \times 10^{-9}$ $\mathrm{h}^{2} / \mathrm{m}^{3}$ ) was multiplied by the number of curies of the radionuclide released during 1994 and divided by the number of hours in a year squared $\left(7.67 \times 10^{7}\right)$.

The MESODIF model predicts that the highest concentrations of radionuclides in the air at an inhabited area would have occurred approximately one mile north of Terreton, Idaho in 1994. The maximum hypothetical dose was calculated for an adult resident of that location from inhalation of air, submersion in air, ingestion of radioactivity on leafy vegetables, ingestion of milk, and exposure due to deposition of particulates on the ground surface. The calculation was based on data presented in Table 4.11 and Figure 4.19. Using a calculated value of $55 \times 10^{-9}$ $\mathrm{h}^{2} / \mathrm{m}^{3}$ (the largest dispersion coefficient value at a location that is inhabited) and allowing for radioactive decay during the $53-\mathrm{km}(33-\mathrm{mi})$ transit of the radionuclides from the TRA/ICPP facilities to the Terreton location, the potential effective dose equivalent from all radionuclides released was calculated to be $0.007 \mathrm{mrem}\left(7 \times 10^{-5} \mathrm{mSv}\right.$ ) (Table 4.13). This dose is $0.007 \%$ of the DOE radiation protection standard for a prolonged period of exposure to a member of the public from all pathways and $0.07 \%$ of the EPA standard for the airborne pathway only. Of the dose received, the immersion pathway accounted for $73 \%$ of the total with ingestion accounting for over $23 \%$. Figure 4.20 illustrates the proportion of specific nuclides comprising the maximum individual dose for 1994. For comparison, the proportions of individual radionuclides contributing to the maximally exposed individual effective dose equivalents for 1990 through 1993 are also shown (Figure 4.21).

\footnotetext{
'D. L. Hoff, E. W. Chew, and S. K. Rope, 1986 Environmental Monitoring Program Report for the Idaho National Engineering Laboratory Site, DOE/ID-12082(86), May 1987.
} 

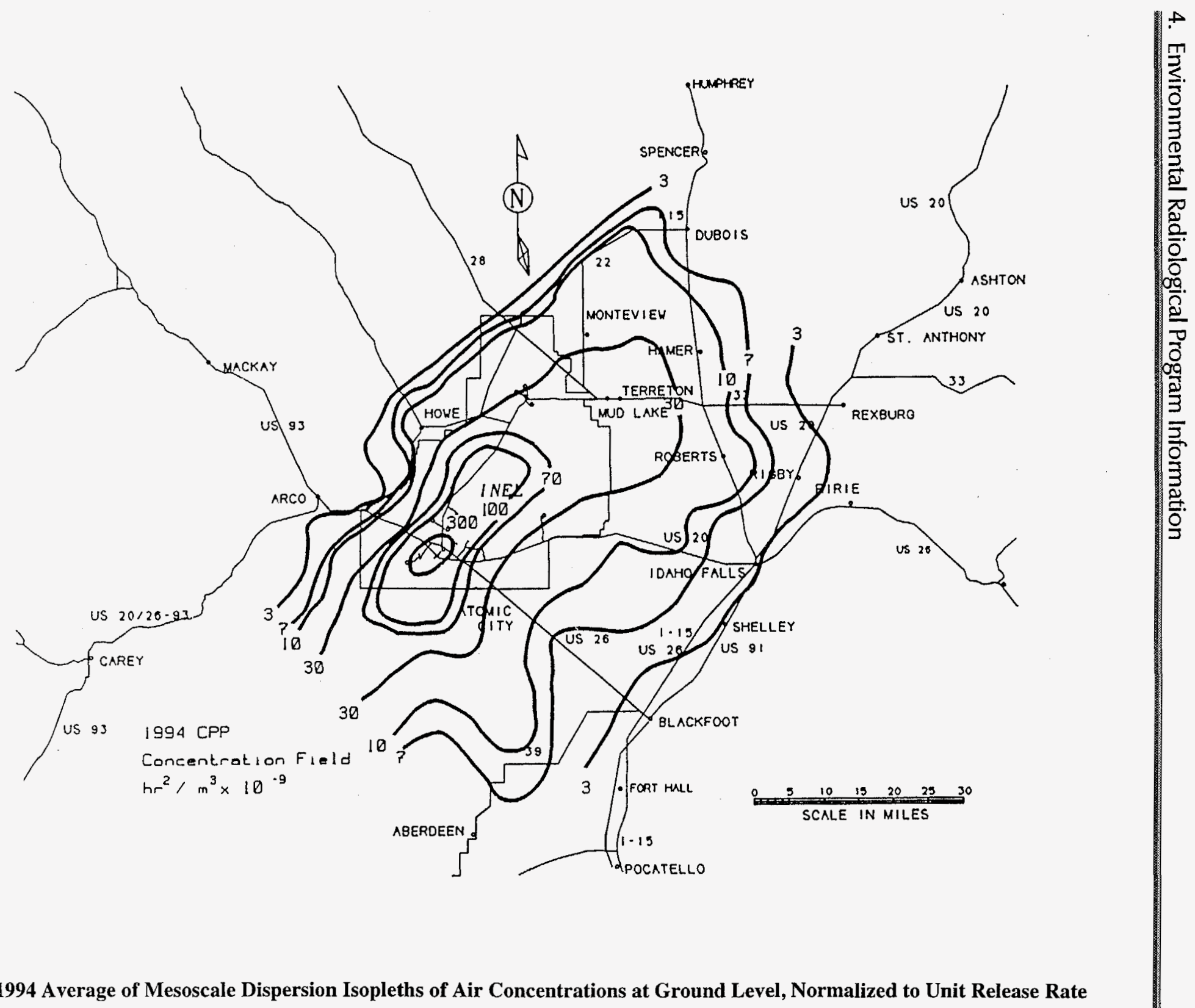

Figure 4.19 1994 Average of Mesoscale Dispersion Isopleths of Air Concentrations at Ground Level, Normalized to Unit Release Rate 


\begin{tabular}{|c|c|c|c|}
\hline \multicolumn{4}{|c|}{$\begin{array}{l}\text { TABLE 4.13 } \\
\text { MAXIMUM INDIVIDUAL EFFECTIVE DOSE EQUIVALENT (1994) }\end{array}$} \\
\hline \multirow[b]{2}{*}{ Radionuclide ${ }^{a}$} & \multirow{2}{*}{$\begin{array}{l}\text { Maximum Offsite } \\
\text { Concentration } \\
(\mu \mathrm{Ci} / \mathrm{mL})^{\mathrm{b}}\end{array}$} & \multicolumn{2}{|c|}{ Maximum Effective Dose Equivalent $^{c}$} \\
\hline & & mrem & $\underline{\mathrm{mSv}}$ \\
\hline${ }^{41} \mathrm{Ar}$ & $4.1 \times 10^{-13}$ & $2.7 \times 10^{-3}$ & $2.7 \times 10^{-5}$ \\
\hline${ }^{88} \mathrm{Kr}+\mathrm{D}$ & $1.0 \times 10^{-13}$ & $1.6 \times 10^{-3}$ & $1.6 \times 10^{-5}$ \\
\hline${ }^{129} \mathrm{I}$ & $2.1 \times 10^{-18}$ & $1.3 \times 10^{-3}$ & $1.3 \times 10^{-5}$ \\
\hline${ }^{90} \mathrm{Sr}+\mathrm{D}$ & $7.0 \times 10^{-19}$ & $2.5 \times 10^{-4}$ & $2.5 \times 10^{-6}$ \\
\hline${ }^{135} \mathrm{Xe}$ & $1.8 \times 10^{-13}$ & $2.3 \times 10^{-4}$ & $2.3 \times 10^{-6}$ \\
\hline${ }^{87} \mathrm{Kr}$ & $2.4 \times 10^{-14}$ & $1.1 \times 10^{-4}$ & $1.1 \times 10^{-6}$ \\
\hline${ }^{138} \mathrm{Xe}+\mathrm{D}$ & $6.2 \times 10^{-16}$ & $8.5 \times 10^{-5}$ & $8.5 \times 10^{-7}$ \\
\hline${ }^{137} \mathrm{Cs}+\mathrm{D}$ & $1.1 \times 10^{-18}$ & $5.4 \times 10^{-5}$ & $5.4 \times 10^{-7}$ \\
\hline${ }^{133} \mathrm{Xe}$ & $3.0 \times 10^{-13}$ & $5.3 \times 10^{-5}$ & $5.3 \times 10^{-7}$ \\
\hline${ }^{85 \mathrm{~m}} \mathrm{Kr}$ & $3.2 \times 10^{-14}$ & $2.6 \times 10^{-5}$ & $2.6 \times 10^{-7}$ \\
\hline${ }^{60} \mathrm{Co}$ & $1.4 \times 10^{-19}$ & $1.4 \times 10^{-5}$ & $1.4 \times 10^{-7}$ \\
\hline${ }^{3} \mathrm{H}$ & $2.4 \times 10^{-14}$ & $1.3 \times 10^{-5}$ & $1.3 \times 10^{-7}$ \\
\hline${ }^{131} \mathbf{I}$ & $1.6 \times 10^{-18}$ & $1.0 \times 10^{-5}$ & $1.0 \times 10^{-7}$ \\
\hline \multicolumn{4}{|c|}{$\begin{array}{l}\text { Table includes only radionuclides which contribute a dose of } 1.0 \times 10^{-5} \mathrm{mrem}\left(1 \times 10^{-7} \mathrm{mSv}\right) \text { or more. When indicated }(+\mathrm{D}) \text {, the } \\
\text { contribution of daughter decay products was also included in the dose calculations. } \\
\text { Estimate of radioactive decay using the distance to the Terreton area and the } 1994 \text { average wind speed in that direction. For } \\
\text { radionuclides where parent-daughter equilibria were used in dose calculations, concentration of the parent is shown. } \\
\text { Effective dose equivalent using dose conversion factors for submersion and deposition given in DOE/EH-0070 and dose } \\
\text { conversion factors for inhalation and ingestion given in DOE/EH-0071. }\end{array}$} \\
\hline
\end{tabular}

As discussed earlier, there are differences in the atmospheric dispersion portions of the MESODIF and CAP-88 air dispersion codes, and the Foundation has chosen to use the MESODIF doses for comparison to most standards and to calculated doses from previous years. The calculated maximum dose resulting from INEL operations is very small $(0.005 \%)$ compared to the measured 130 mrem average dose individuals in southeastern Idaho received from cosmic and terrestrial radiation during 1994 . The calculated dose is even smaller compared to the total estimated effective dose equivalent from natural background radiation of about 350 mrem (see Table 4.10). For perspective, the calculated dose may also be compared to the approximately 30 mrem average dose received from medical diagnostic procedures, the 4 mrem average dose received from highway and road construction materials, and the 0.04 to 0.1 mrem received from luminous watches and clocks ${ }^{\mathrm{a}}$. Another source has estimated that the average five-hour jet flight contributes a dose of about 0.7 mrem to passengers, and that the average television viewer receives about 0.05 to 0.1 mrem annually ${ }^{\mathrm{b}}$.

\footnotetext{
${ }^{a}$ National Council on Radiation Protection and Measurements, Ionizing Radiation Exposure of the Population of the United States, NCRP Report No. 93, September 1, 1987.

${ }^{b}$ United Nations Scientific Committee on the Effects of Atomic Radiation Sources and Biological Effects, United Nations: New York, 1982.
} 


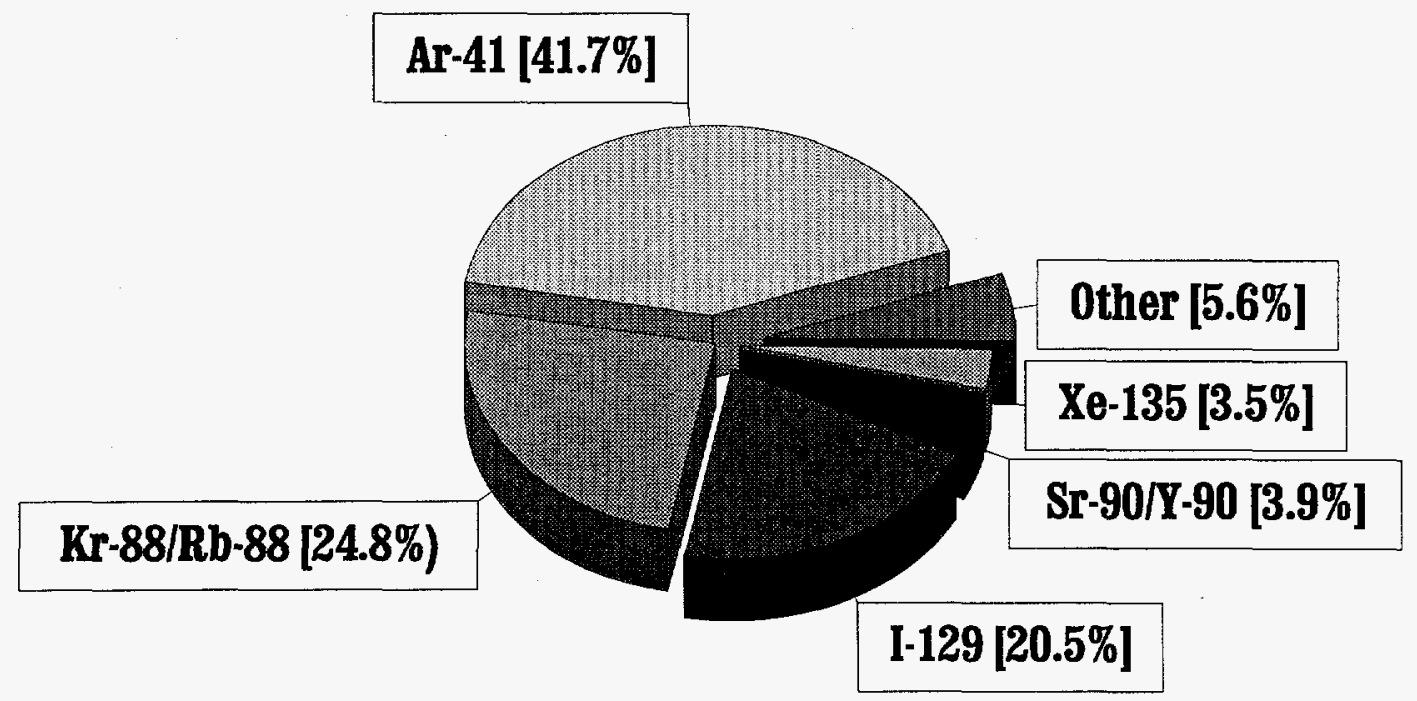

Figure 4.20 Radionuclides Contributing to Maximum Individual Dose (1994)

\section{Maximum Individual Dose--Game Ingestion Pathway}

The potential dose to an individual from occasional ingestion of meat from game animals continues to be investigated. One group of studies involves the calculation of potential doses to individuals who might eat ducks that reside briefly upon liquid waste ponds used for the disposal of low-level reactor effluent. In one study, conducted in 1974-1978, wild ducks using liquid waste ponds at TRA were collected. The average potential whole-body dose equivalent from gamma emitters due to consumption of the meat of cooked ducks (not including the juices in the pan) was calculated to be $10 \mathrm{mrem}^{\mathrm{a}}$.

In another study, wing-clipped mallards were released on the TRA pond for 56-188

\footnotetext{
${ }^{3}$ D. K. Halford et al., "Radionuclide Concentrations in Waterfowl Using a Liquid Radioactive Disposal Area and the Potential Radiation Dose to Man," Health Physics, 40, February 1981, pp. 173-181.
}

days before collection. Various tissues were analyzed for concentrations of ${ }^{90} \mathrm{Sr},{ }^{238} \mathrm{Pu}$, ${ }^{239 / 240} \mathrm{Pu},{ }^{241} \mathrm{Am},{ }^{242} \mathrm{Cm}$, and ${ }^{244} \mathrm{Cm}$. The potential effective dose equivalent to a human consuming the entire muscle and liver mass of one experimental duck with average nuclide concentrations was 0.046 mrem from those specific nuclides $^{\mathrm{b}}$. In the most recent study, migratory waterfowl were collected from several ponds on the INEL ranging from the sewage disposal pond at NRF to the radioactive waste pond at TRA ${ }^{c}$. Several tissues from these birds were analyzed for gammaemitting radionuclides. The predicted committed effective dose equivalent to an individual eating the entire muscle and liver mass

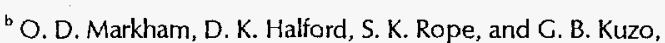
"Plutonium, Am, Cm, and $\mathrm{Sr}$ in Ducks Maintained on Radioactive Leaching Ponds in Southeastern Idaho," Health Physics, 55, 3, pp. 577-524.

' R. C. Morris, S. K. Rope, and O. D. Markham, Use of Wastewater Ponds by Waterfowl in Southeast Idaho: 1984-1986, submitted to Great Basin Naturalist, April 1995.
} 


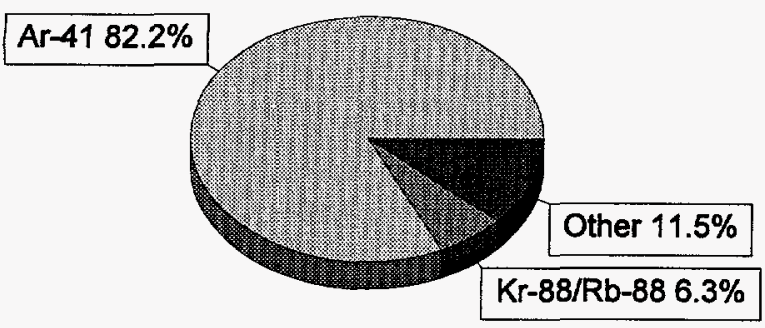

1990

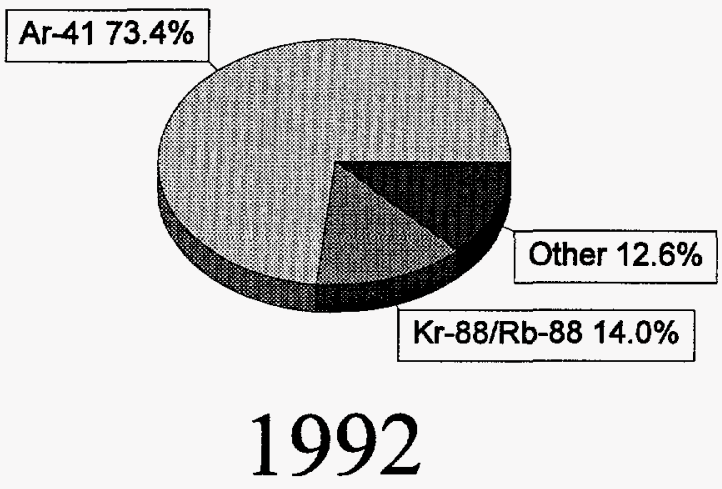

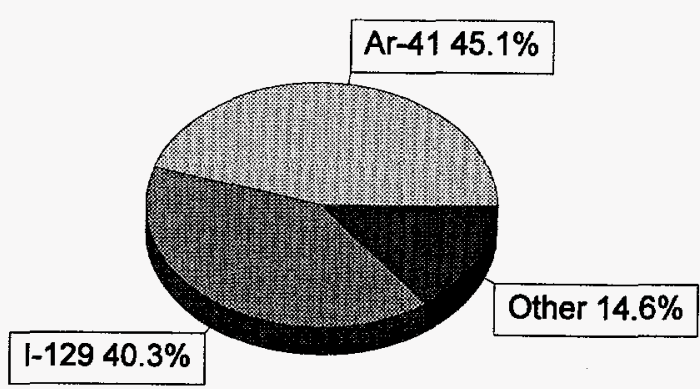

1991

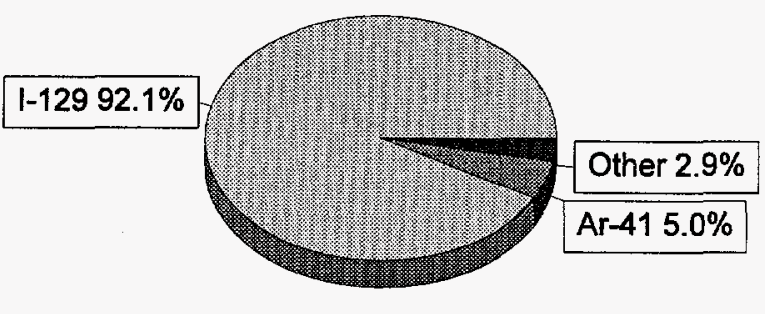

1993

\section{Figure 4.21 Radionuclides Contributing to Maximum Individual Dose (1990-1993)}

of the most contaminated duck (collected from the TRA radioactive waste pond) was 4.0 mrem $(0.040 \mathrm{mSv})$. The median committed effective dose equivalent, based on all waterfowl in the study, was $0.0020 \mathrm{mrem}\left(2.0 \times 10^{-5}\right.$ $\mathrm{mSv}$ ).

The most recent estimates (based on banding data from nearby wildlife refuges) indicate that a maximum of $7.2 \%$ of the waterfowl which visit the TRA and ICPP radioactive waste ponds each year may potentially be harvested by Idaho hunters during the same year. In 1984-1985, this was approximately 45 ducks $^{\mathrm{a}}$. Because a small number of people are exposed, the population dose associated with this pathway is very small.

The doses calculated above are based on the unlikely assumption that the duck would

'Unpublished data from R.C. Morris. 
be killed and eaten immediately after leaving the pond, so a lower dose would be more realistic due to biological elimination of the radioactivity. For example, the largest contributor to the dose, ${ }^{137} \mathrm{Cs}$, has an effectivehalf-life in mallard ducks of 11.2 days $^{\mathrm{a}}$. This means that half of the ${ }^{137} \mathrm{Cs}$ present when a given duck leaves the pond would be eliminated in 11.2 days. At the end of the next 11.2 days, half of the remaining radioactivity (or one-fourth of the original activity) would be eliminated, and so on until the amount of ${ }^{137} \mathrm{Cs}$ present in the duck's tissues can no longer be detected.

The TRA radioactive waste ponds have been drained as part of a CERCLA Interim Action. A new, hypalon-lined pond has been constructed near the location of the old pond. In order to obtain revised data on the concentrations of radionuclides in waterfowl, and to assess usage of the new pond, the Environmental Science and Research Foundation initiated a new study in 1994. Beginning in 1995, waterfowl will be collected from the TRA pond and from other disposal ponds on the INEL. Control samples will be taken from offsite areas.

The highest estimated potential wholebody dose equivalent to a person eating the entire muscle mass of a sage grouse that summered near the TRA-ICPP area was 2 mrem $^{\mathrm{b}}$. The maximum whole-body dose equivalent from consumption of sage grouse from other onsite locations and offsite areas ranges from 0.01 to $0.04 \mathrm{mrem}$.

\footnotetext{
aHalford, D.K., O.D. Markham, and G.C. White, "Biological
Elimination of Radioisotopes by Mallards Contaminated at a Liquid
Radioactive Waste Disposal Area, Health Physics, 45, pp 745-756.

${ }^{2}$ Halford, D.K., O.D. Markham, and G.C. White, "Biological
Elimination of Radioisotopes by Mallards Contaminated at a Liquid

"Halford, D.K., O.D. Markham, and G.C. White, "Biological
Elimination of Radioisotopes by Mallards Contaminated at a Liquid
Radioactive Waste Disposal Area, Health Physics, 45, pp 745-756.

b J. W. Connelly and O. D. Markham, "Movements and Radionuclide Concentrations of Sage Grouse in Southeastern

Idaho," Joumal of Wildlife Management, 47, 1, January 1983, pp. 169-175.

Radioactive Waste DisposalArea, Heath Physics, 45, pp i
}

The maximum potential whole-body dose equivalent to a person eating the muscle tissue of one mourning dove from the TRA pond area was 0.3 mrem. The average whole-body dose equivalent to people consuming doves migrating from onsite to offsite areas was 0.01 mrem, which was the same as for control birds collected far from the INEL ${ }^{\mathrm{c}}$.

A conservative (or high) estimate of the potential whole-body dose equivalent which could be received by a single individual eating the entire muscle and liver mass of an antelope (collected on the INEL after August 1975) with the highest levels of radionuclides was $0.2 \mathrm{mrem}^{\mathrm{d}}$. Game animal tissues collected on the INEL during the past few years have shown much lower concentrations of radionuclides than in 1975 , resulting in a reduced potential dose from this pathway.

\section{0-Kilometer Population Dose}

An estimate was made of the collective effective dose equivalent (population dose) from inhalation, submersion, ingestion, and deposition that could have been received by all members of the public within an $80-\mathrm{km}$ (50-mi) radius of the TRA/ICPP facilities. This population dose (person-rem) was calculated by a computer program that multiplies the population number in each square mile by the dispersion coefficient at that point $\left(\mathrm{h}^{2} / \mathrm{m}^{3}\right)$ and the normalized dose received at the location of the maximally exposed individual $\left(\mathrm{rem} / \mathrm{year} / \mathrm{h}^{2} / \mathrm{m}^{3}\right)^{\mathrm{e}}$.

\footnotetext{
'O. D. Markham and D. K. Halford, "Radionuclides in Mourning Doves Near a Nuclear Facility Complex in Southeastern Idaho," The Wilson Bulletin, 94, 2, June 1982, pp. 185-195.

d O. D. Markham and D. K. Halford, "Effects of Decreased Effluents from Nuclear Fuel Reprocessing on Cs-137 Concentrations in Wildlife," Northwest Science, 59, 3, August 1985.
} 
The calculation overestimates dose, however, because radioactive decay of the isotopes was not calculated during transport over distances greater than the $52 \mathrm{~km}(32 \mathrm{mi})$ from the TRA/ICPP facilities to the Terreton maximum location. Idaho Falls, for example, is about $66 \mathrm{~km}(41$ mi) from TRA/ICPP. Neither residence time nor shielding by housing was considered when calculating the MESODIF dose upon which the collective dose is based.

The 1994 MESODIF population dose within each census division was obtained by summing the results from appropriate areas contained within those divisions (Table 4.14). The total $80-\mathrm{km}(50-$ mi) population dose was the sum of population doses for the various census divisions. The estimated potential population dose was 0.06 person-rem $\left(6 \times 10^{-4}\right.$ person-

Sv) to a population of about 121,500 . When compared with an ap-proximate population dose of 42,500 person-rem (425 person-Sv) from natural background radiation, this represents an increase of only about $0.00014 \%$. The dose of 0.06 person-rem can also be compared to the following estimated population doses for the same size population: 3600 person-rem for medical diagnostic

'D. L. Hoff, E. W. Chew, and S. K. Rope, 1986 Environmental Monitoring Program Report for the Idaho National Engineering Laboratory Site, DOE/ID-12082(86), May 1987.

TABLE 4.14

80-KM POPULATION DOSE (1994)

Population Dose

Census Division

Aberdeen

Alridge (part)

American Falls (part)

Arco

Atomic City (city)

Atomic City (division)

Carey (part)

Challis (part)

Firth

Fort Hall (part)

Hamer

Howe

Idaho Falls West

Leadore (part)

Lewisville-Menan (part)

Mackay

Moreland

Rigby

Roberts

Shelley

a Population based on the 1990 Census Report for Idaho.

\begin{tabular}{|c|c|c|}
\hline \multirow[b]{2}{*}{ Population $^{\mathrm{a}}$} & \multicolumn{2}{|c|}{ Population Dose } \\
\hline & Person-rem & Person-Sv \\
\hline 2,760 & $1.80 \times 10^{-3}$ & $1.80 \times 10^{-5}$ \\
\hline 160 & $4.74 \times 10^{-5}$ & $4.74 \times 10^{-7}$ \\
\hline 200 & $5.07 \times 10^{-5}$ & $5.07 \times 10^{-7}$ \\
\hline 2,600 & $4.85 \times 10^{-4}$ & $4.85 \times 10^{-6}$ \\
\hline 25 & $7.26 \times 10^{-5}$ & $7.26 \times 10^{-5}$ \\
\hline 2,300 & $2.40 \times 10^{-4}$ & $2.40 \times 10^{-6}$ \\
\hline 12,450 & $1.75 \times 10^{-3}$ & $1.75 \times 10^{-5}$ \\
\hline 120 & $2.70 \times 10^{-6}$ & $2.70 \times 10^{-8}$ \\
\hline 10 & $7.04 \times 10^{-7}$ & $7.04 \times 10^{-9}$ \\
\hline 3,050 & $8.84 \times 10^{-4}$ & $8.84 \times 10^{-6}$ \\
\hline 3,920 & $2.52 \times 10^{-4}$ & $2.52 \times 10^{-6}$ \\
\hline 2,400 & $9.76 \times 10^{-3}$ & $9.76 \times 10^{-5}$ \\
\hline 325 & $7.48 \times 10^{-3}$ & $7.48 \times 10^{-5}$ \\
\hline 63,500 & $1.94 \times 10^{-2}$ & $1.94 \times 10^{-4}$ \\
\hline 1,750 & $2.73 \times 10^{-4}$ & $2.73 \times 10^{-6}$ \\
\hline 15 & $2.21 \times 10^{-6}$ & $2.21 \times 10^{-8}$ \\
\hline 2,700 & $1.33 \times 10^{-3}$ & $1.33 \times 10^{-5}$ \\
\hline 1,200 & $1.38 \times 10^{-5}$ & $1.38 \times 10^{-7}$ \\
\hline 8,150 & $3.27 \times 10^{-3}$ & $3.27 \times 10^{-5}$ \\
\hline 1,000 & $4.89 \times 10^{-4}$ & $4.89 \times 10^{-6}$ \\
\hline 1,430 & $2.26 \times 10^{-3}$ & $2.26 \times 10^{-5}$ \\
\hline 6,400 & $1.86 \times 10^{-3}$ & $1.86 \times 10^{-5}$ \\
\hline 4,900 & $2.41 \times 10^{-3}$ & $2.41 \times 10^{-5}$ \\
\hline 90 & $3.22 \times 10^{-4}$ & $3.22 \times 10^{-6}$ \\
\hline 121,465 & $5.92 \times 10^{-2}$ & $5.92 \times 10^{-4}$ \\
\hline
\end{tabular}

procedures, about 480 person-rem from exposure to highway and road construction materials or 6 to 12 person-rem for television viewing ${ }^{\mathrm{a}}$.

\section{Summary}

Table 4.15 summarizes the calculated annual effective dose equivalents from 1994

${ }^{a}$ National Council on Radiation Protection and Measurements, Exposure of the Population in the United States and Canada from Natural Background Radiation, NCRP Report No. 94, December 30 , 1987. 
INEL operations using both CAP-88 and MESODIF air dispersion models and compares these doses to the EPA airborne pathway standard and to the estimated effective dose equivalent from natural background.

The contribution of game animal consumption to the population dose has not been calculated because a small percentage of the population hunts game, few of the animals killed have spent time on the INEL, and most of the animals that do migrate from the INEL have background concentrations of radionuclides in their tissues. The total population dose contribution from these pathways would, realistically, be less than the sum of population doses from inhalation of air, submersion in air, and deposition on soil.

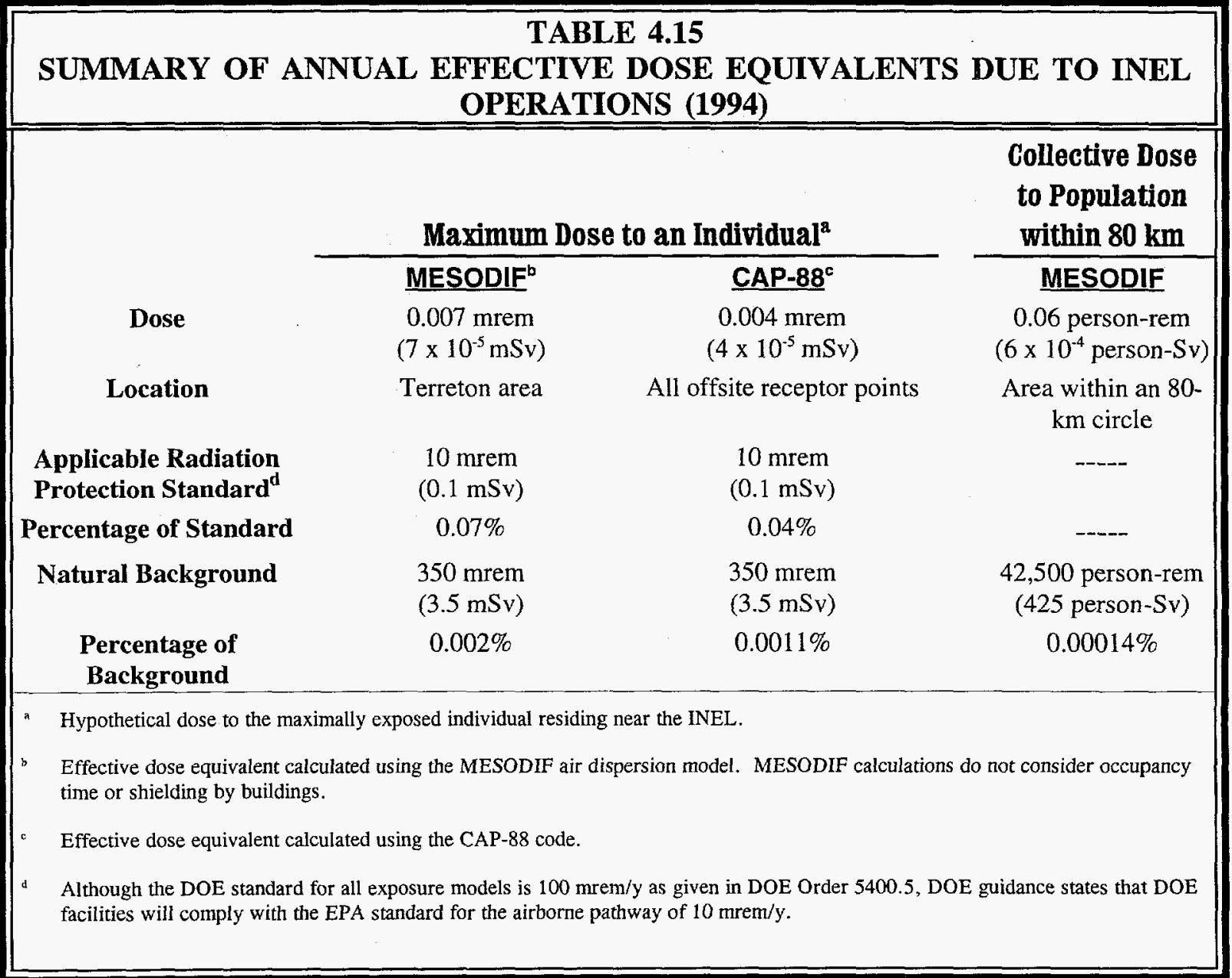




\section{Ground Water}

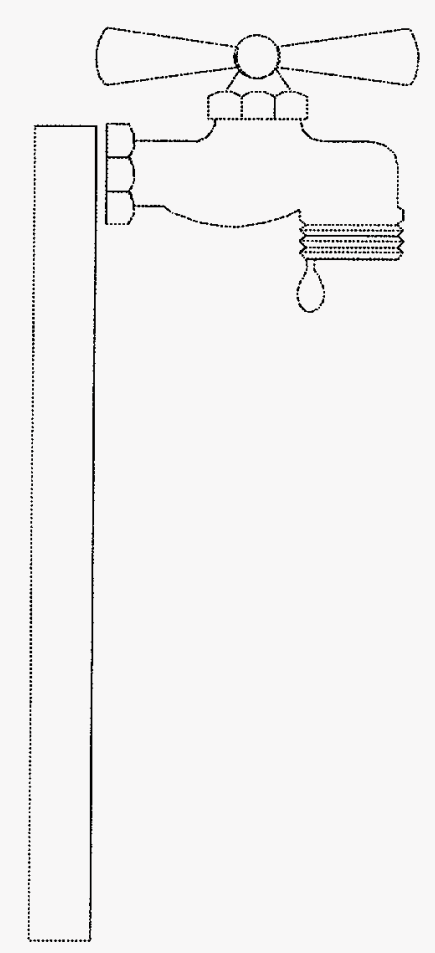




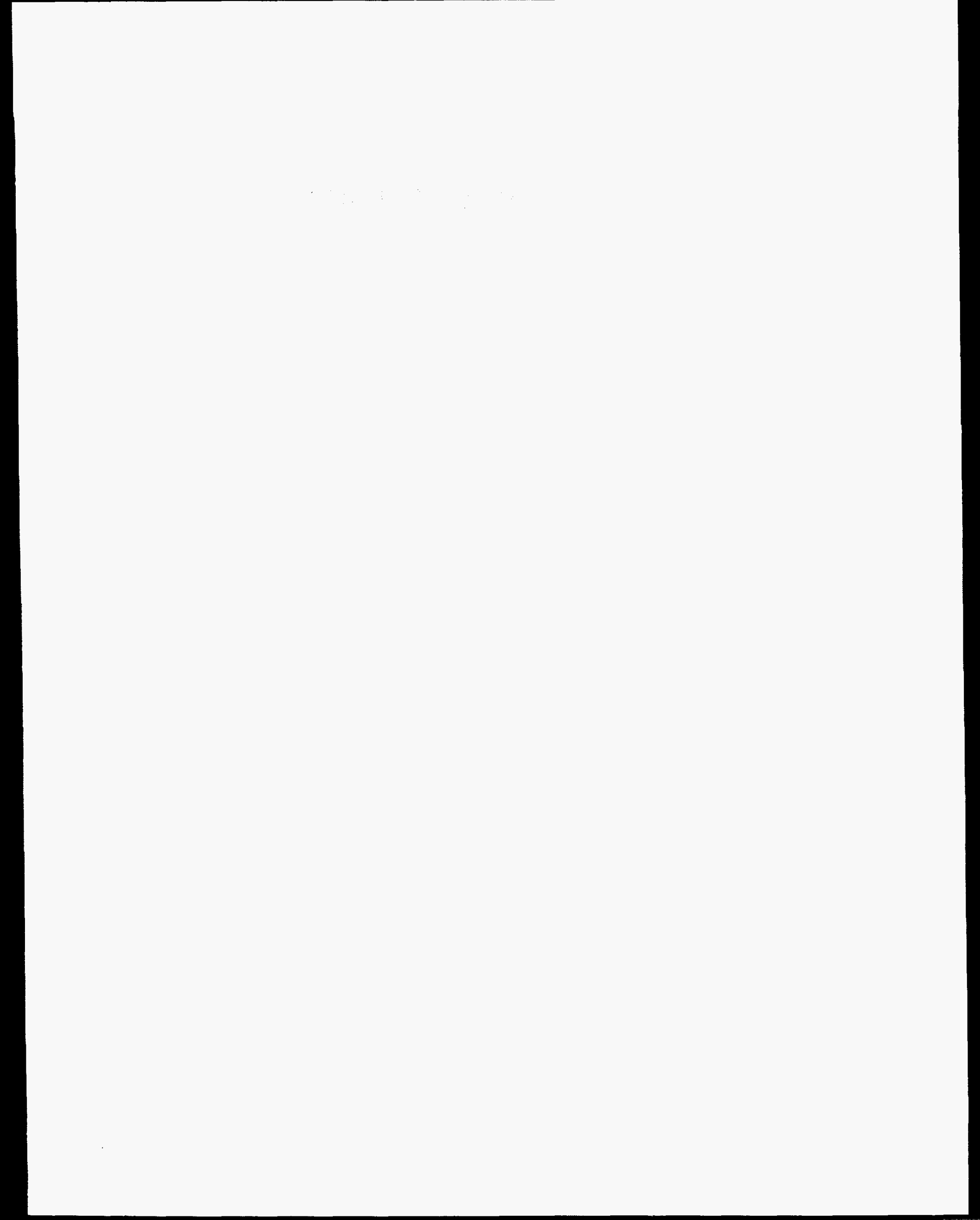




\section{GROUND WATER}

\subsection{U.S. GEOLOGICAL SURVEY PROGRAM INFORMATION}

\section{U.S. Geological Survey (USGS) Program Description}

No streams or rivers flow from within the INEL to locations outside the boundaries. Water monitoring conducted in 1994 included onsite and offsite ground-water monitoring plus samples from the Snake River and other surface streams and tributaries in the INEL vicinity, some of which flow onto the Site and sink into its porous soils. A brief description of the hydrogeology of the INEL and the movement of water in the Snake River Plain aquifer was given in Chapter 1. Further information may be found in USGS publications.

The Snake River Plain Aquifer, which lies beneath the INEL, serves as one of the primary sources for drinking water and crop irrigation in the Snake River Basin. The U.S. Geological Survey (USGS) has investigated hydrologic conditions at the INEL since the Site's origination, and currently conducts an extensive monitoring program for the aquifer and perched water bodies above it. This program includes collection of samples on the INEL and at a few locations beyond the southern and western boundaries.

The USGS maintains more than 120 aquifer observation wells on or near the INEL. Additionally, 45 wells are available for sampling perched ground-water bodies. In addition, more than 120 shallow auger holes have been drilled to monitor shallow perched ground-water bodies. Figures 5.1 and 5.2 show USGS sampling locations. USGS monitors water levels in wells, and radiological and nonradiological substances in water from the aquifer. Various USGS reports, available from the INEL Project Office, contain maps showing the frequency of water level measurements and water sample collections. Recent information has also been published on the shape and extent of waste plumes (i.e., the spread of various contaminants in the water of the aquifer and perched water from INEL facilities) as they were between 1982 and $1988^{\mathrm{a}}$. An update to this report is in review and is expected to be published during 1995. Figures 5.3 and 5.4, showing plumes for tritium and ${ }^{90} \mathrm{Sr}$ as they existed in 1991, are based on more recent data collected by the USGS.

The USGS routine ground-water surveillance program was summarized in Chapter 3, "Environmental Program Information." In 1994, the routine program included collection of 364 samples for radionuclides and inorganic constituents including trace elements, and 74 samples for purgeable organic compounds.

The USGS also conducts special studies of the ground water of the Snake River Plain that are not included in this summary. These special studies provide more specific geological and hydrological information on the flow and recharge of the aquifer and the movements of radioactive and nonradioactive substances in the ground water. Most of the information from these studies is published in USGS reports.

Results of recently published monitoring or surveillance activities are summarized in the annual INEL Site Environmental Report during the year of publication, but may refer to sampling programs that took place in earlier years. USGS results and information for securing copies of their reports are available upon request from the USGS INEL Project Office at CFA.

${ }^{2}$ B. R. Orr and L. D. Cecil, Hydrologic Conditions and Distribution of Selected Chemical Constituents in Water, Snake River Plain Aquifer, Idaho National Engineering Laboratory, Idaho, 1986 to 1988, U.S. Geological Survey, Water Resources Investigation Report 91-4047, DOE/ID-22096, March 1991. 


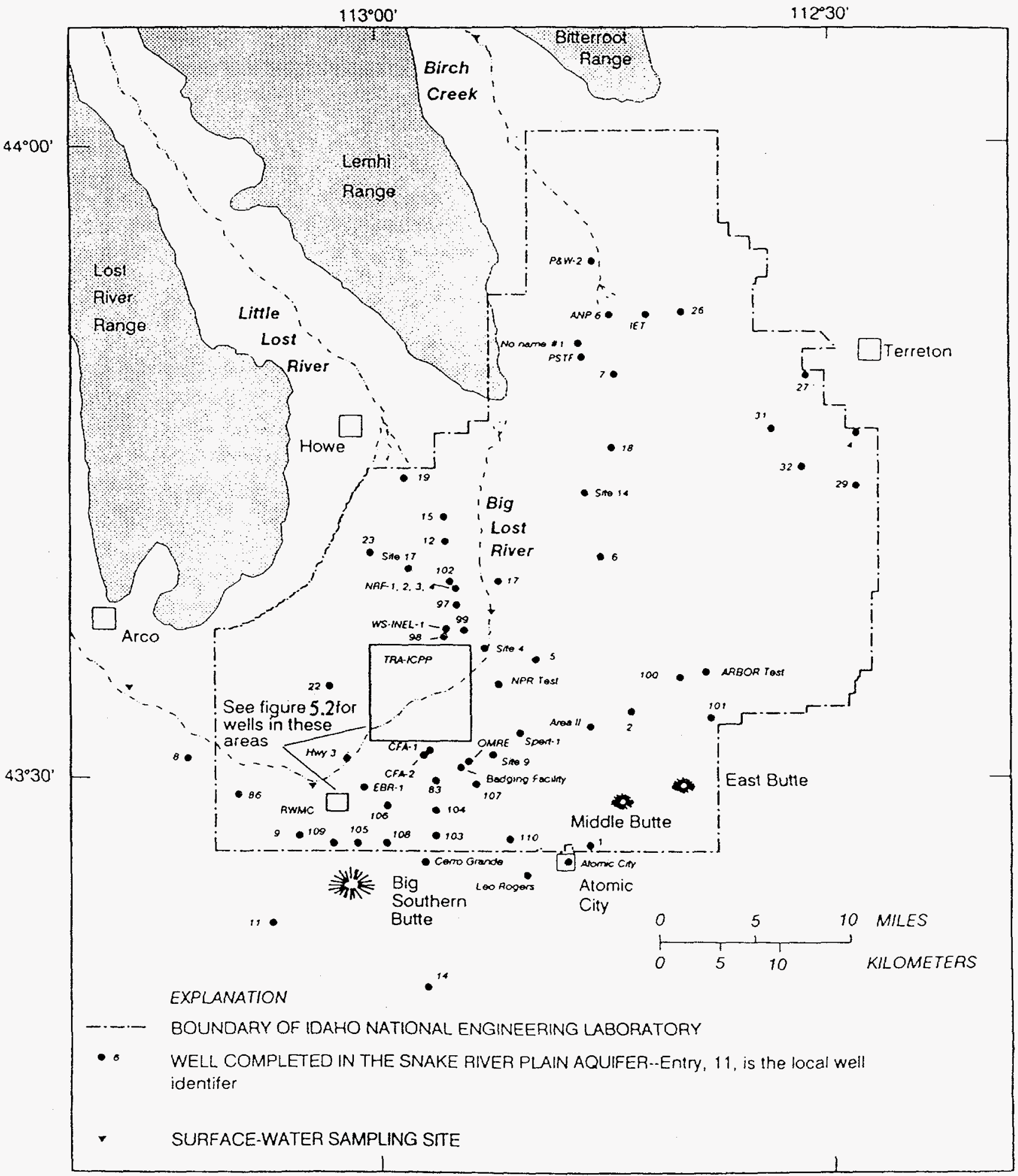

Figure 5.1 USGS Well Locations 


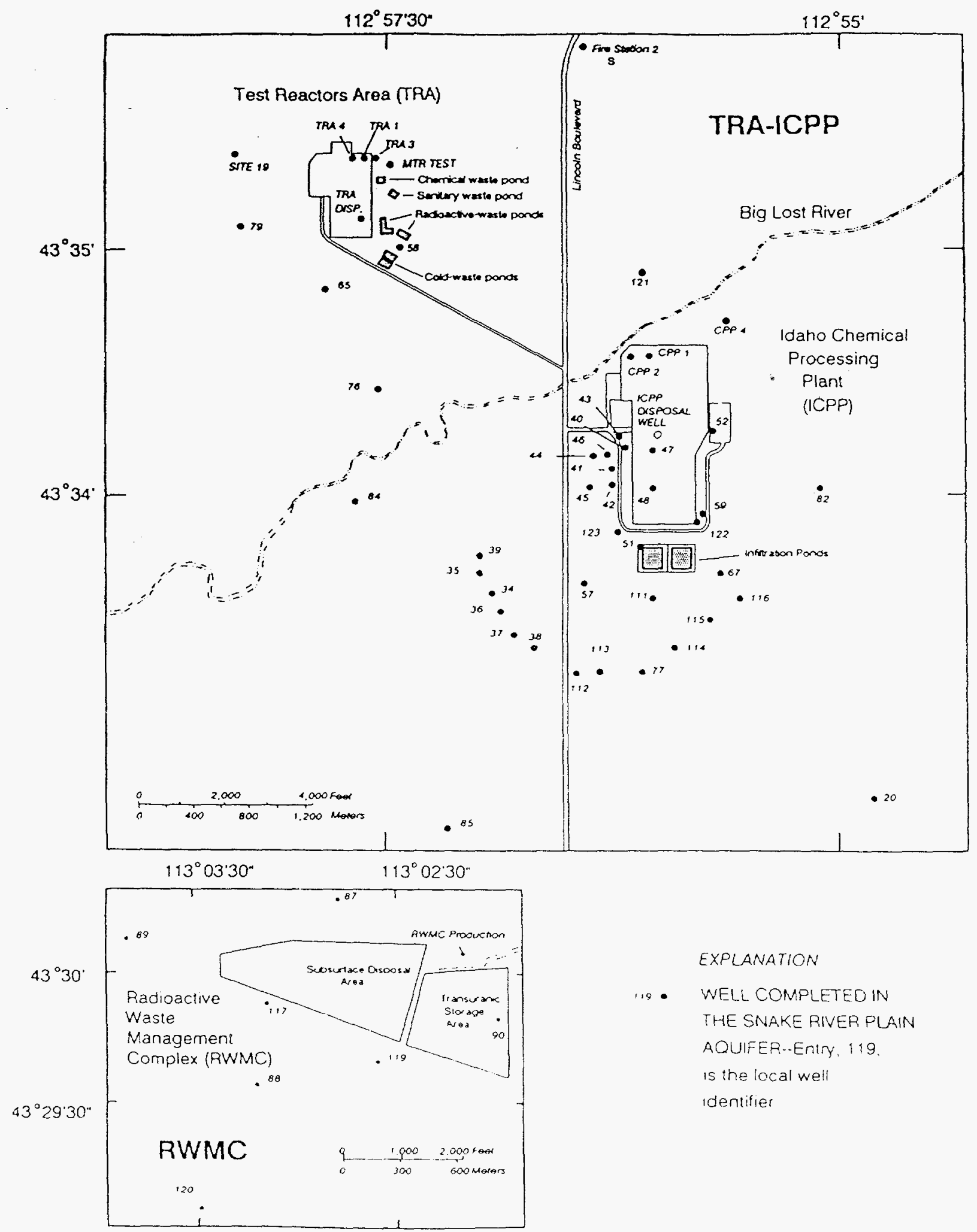

Figure 5.2 USGS well locations at ICPP-TRA and RWMC 


\section{EXPLANATION}

LINE OF EQUAL TRITIUM CONCENTRATION Interval variable; concentration in picacuries per milliliter

OBSERVATION WELL COMPLETED IN THE SNAKE RIVER PLAIN AQUIFER AND SAMPLED FOR TRITIUM

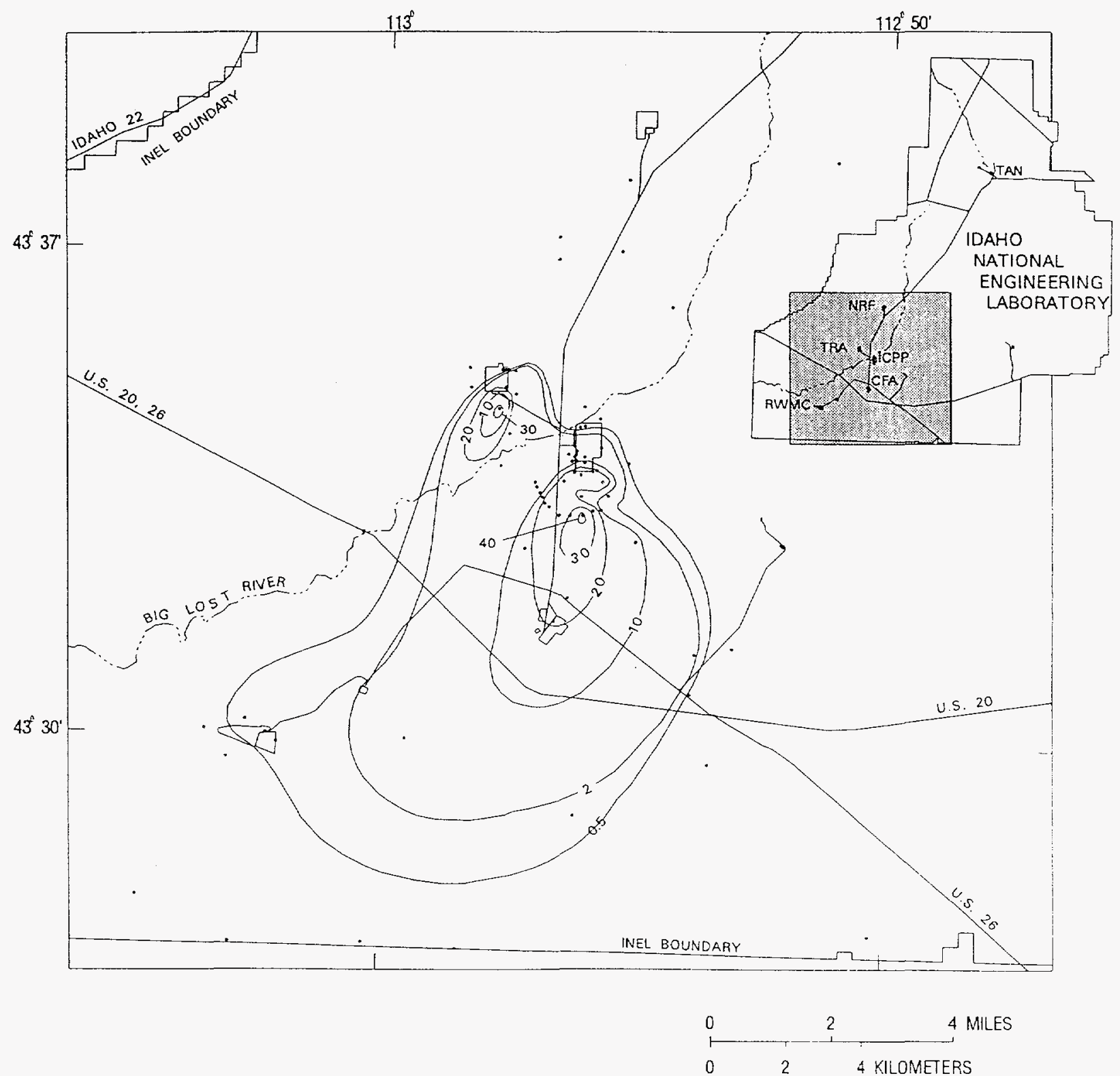

Figure 5.3 Distribution of tritium in the Snake River Plain Aquifer on the INEL, 1991 (constructed from data collected by the U.S. Geological Survey) 
EXPLANATION

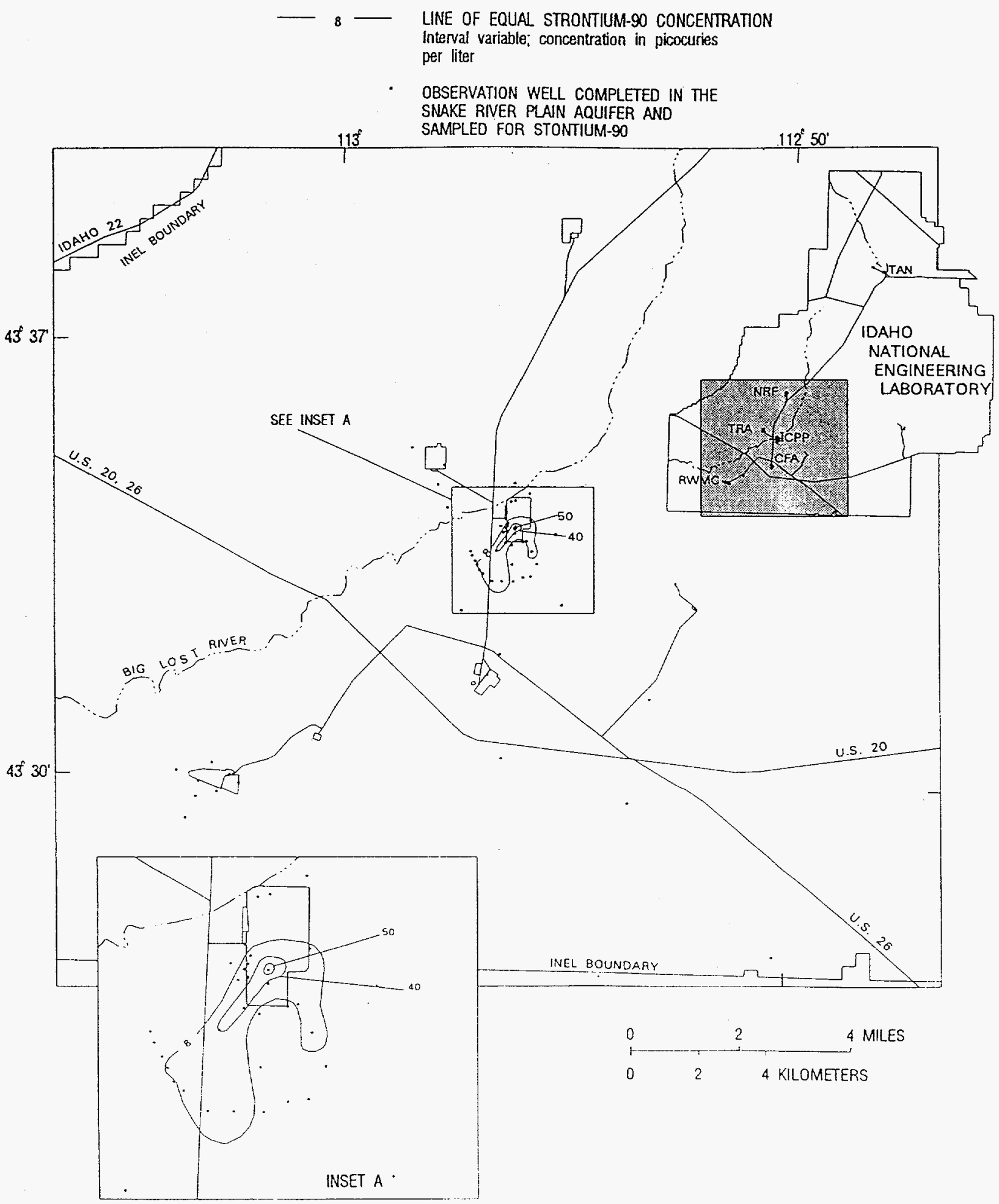

Figure 5.4 Distribution of ${ }^{90} \mathrm{Sr}$ in the Snake River Plain Aquifer on the INEL, 1991 (constructed from data collected by the U.S. Geological Survey) 


\section{USGS Special Studies}

Iodine-129. Results of a USGS study on ${ }^{129} \mathrm{I}$, a component of wastewater generated at the Idaho Chemical Processing Plant, were published in 1994. The study used an extremely sensitive accelerator mass spectrometry technique for analysis of ground-water samples that allowed for the detection of ${ }^{129}$ I concentrations that were two to six orders of magnitude less than those previously achievable. For the study, 51 wells that obtain water from the Snake River Plain Aquifer and one well that obtains water from a perched-water zone were sampled.

The report found a mean ${ }^{129} \mathbf{I}$ concentration of $0.81 \pm 0.19 \mathrm{pCi} / \mathrm{L}$, a decrease from the mean concentration of $1.30 \pm 0.26$ $\mathrm{pCi} / \mathrm{L}$ found in a 1986 study. The highest concentration measured was $3.82 \pm 0.38 \mathrm{pCi} / \mathrm{L}$, obtained in water from well \#42 (Figure 5.2). The greatest concentration in a well used for drinking water was $0.28 \pm 0.04 \mathrm{pCi} / \mathrm{L}$ in well CFA \#1. This value was $1.3 \%$ of the proposed EPA maximum contaminant level for ${ }^{129} \mathrm{I}$ in community drinking water systems.

Concentrations of ${ }^{129} \mathrm{I}$ in wells \#105 and $\# 108$ at the southern INEL boundary and in wells \#11 and \#14 south of the INEL were considered to be one to two orders of magnitude greater than the calculated background concentration. The reported concentrations in these wells, however, were less than $0.004 \%$ of the proposed drinking water standard. Using data from the study, the ground-water velocity in the aquifer was calculated to be approximately 6 feet per day, similar to values obtained from other studies.

"L.J. Mann and T.M. Beasley, lodine-129 in the Snake River Plain Aquifer at and near the Idaho National Engineering Laboratory, Idaho, 1990-1991; DOE/ID-22115, USGS Water-Resources Investigations Report 94-4053, 1994.
Snake River Plain Aquifer. The USGS and the Idaho Department of Water Resources, in response to a request from DOE, sampled 18 sites in 1992 as part of an ongoing long-term project to monitor water quality of the Snake River Plain Aquifer from the southern boundary of the INEL to the Hagerman, Idaho area. A report on the data generated was published in $1994^{\mathrm{b}}$. Water samples were collected and analyzed for manmade pollutants and naturally occurring constituents from 13 irrigation wells, one domestic well, one spring, two stock wells, and one public supply well.

None of the radionuclides, inorganic constituents, or organic compounds for which the samples were analyzed exceeded the established maximum contaminant levels for drinking water. Most of the radionuclide, inorganic constituent, dissolved organic carbon, and surfactant analyses exceeded the reporting levels for these compounds. None of the samples contained reportable concentrations of purgeable organic compounds or pesticides. Total coliform bacteria were present in nine of the samples.

Dissolved Radon-222. The U.S. Geological Survey reported results from a study of the naturally occurring radioactive gas ${ }^{222} \mathrm{Rn}$ in 338 springs and wells throughout Idaho ${ }^{\mathrm{c}}$. The study found ${ }^{222} \mathrm{Rn}$ concentrations ranging from $-58 \pm 30 \mathrm{pCi} / \mathrm{L}$ to $5715 \pm 66 \mathrm{pCi} / \mathrm{L}$ with a mean concentration of $446 \mathrm{pCi} / \mathrm{L}$. Over half of the wells sampled throughout the state of Idaho contained ${ }^{222} \mathrm{Rn}$ concentrations that were greater than the proposed EPA maximum contaminant

\footnotetext{
${ }^{b}$ R. C. Bartholomay, D. D. Edwards, and L. J. Campbell; Radionuclides, Inorganic Constituents, Organic Compounds, and Bacteria in Water from Selected Wells and Springs from the Southern Boundary of the Idaho National Engineering Laboratory to the Hagerman Area, Idaho, 1992; DOE/ID-22114; USGS Open-File Report 94-76; 1994.

L. DeWayne Cecil, D.J. Parliman, Daniel D. Edwards, and H.W. Young; Concentrations of Dissolved Radon-222 in Water from Selected Wells and Springs in fdaho, 1990-91; DOE/ID-22113, USGS Open-File Report 94-66, 1994
} 
level of $300 \mathrm{pCi} / \mathrm{L}$ for this naturally-occurring radionuclide.

\section{Chemical Monitoring}

According to a recent USGS report on background concentrations of chemical constituents, operations at the INEL have probably affected local concentrations of several purgeable organic compounds including carbon tetrachloride, 1,1,1-trichloroethane, trichloroethylene, tetrachloroethylene, chloroform, and 1,1-dichloroethylene in the aquifer under the INEL ${ }^{\text {a }}$. However, the INEL has apparently had no effect on the concentrations of other purgeable organic compounds, pesticides, or fluoride. In the trace elements group, operations have not affected concentrations of arsenic, barium, cadmium, mercury, or silver; but they may have had a slight effect on the concentrations of dissolved chromium, lead, and selenium.

Sampling for purgeable organic compounds in ground water was conducted by the USGS at the INEL during 1994. Water samples from 6 onsite production wells and 31 groundwater quality monitoring wells that tap the Snake River Plain Aquifer were collected by USGS personnel and submitted to the USGS National Water Quality Laboratory in Arvada, Colorado, for analysis for 60 purgeable organic compounds. A USGS report on the purgeable organic compounds sampling program describes in detail the methods used to collect the water samples and to ensure sampling and analytical quality ${ }^{\mathrm{b}}$. In the 1994 USGS set of

${ }^{2}$ B. R. Orr, L. D. Cecil, L. L. Knobel, Background Concentrations of Selected Radionuclides, Organic Compounds, and Chemical Constituents in Croundwater in the Vicinity of the Idaho National Engineering Laboratory, U.S. Geological Survey, Water-Resources Investigations Report 91-4015, DOE/ID-22094, February 1991.

${ }^{\circ} \mathrm{M}$. J. Liszewski and L. J. Mann, Purgeable Organic Compounds in Ground Water at the Idaho National Engineering Laboratory, idaho--1990 and 1991, DOE/ID-22104, USCS Open-File Report 92-174, DOE/ID-22089, July 1992. samples from the INEL, five purgeable organic compounds were reported at concentrations above the laboratory reporting level of $0.2 \mu \mathrm{g} / \mathrm{L}$ : carbon tetrachloride, chloroform, 1,1,1-trichloroethane, trichloroethylene, and tetrachloroethylene (Table 5.1). The only production wells sampled by the USGS in 1994 containing purgeable organic compounds were the RWMC production well and the inactive Fire Station \#2 production well. All detected concentrations were well below the EPA maximum contaminant levels for each compound (Table IV in Appendix A).

\subsection{INEL CONTRACTOR PROGRAM INFORMATION}

\section{Bacteriological Monitoring}

Potable water at the INEL was monitored for coliform bacteria monthly by contractor personnel and analyzed by the EG\&G/LITCO Environmental Hygiene Laboratory. Between 44 and 60 samples per month were collected from the active drinking water systems at INEL facilities. While "total coliform" bacteria may occasionally be detected in drinking water samples, concern arises only if Escherichia coli ( $E$. coli) is present. Although most strains of $E$. coli are not dangerous and are normally found in human and animal intestines, the presence of this organism indicates possible contamination of the water by fecal waste. If even one colony of $E$. coli is found in a sample by the laboratory, that particular drinking water system is cleaned, re-sampled, and tested again, until it is clear of bacteria. Corrective action to purify the water may vary somewhat from one facility to another.

For January to May 1994 no coliform were found at any facility. In June, the sample 


\begin{tabular}{|c|c|c|c|c|c|c|}
\hline \multicolumn{7}{|c|}{\begin{tabular}{|c|c|} 
Table 5.1 \\
Purgeable Organic Compounds in USGS Well Samples (1994) \\
\end{tabular}} \\
\hline \multirow{3}{*}{$\frac{\text { Well ID }}{34}$} & Date & $\begin{array}{l}\text { Carbon Tetra- } \\
\text { chloride }\end{array}$ & Chloroform & $\begin{array}{l}\text { 1,1,1-trichloro- } \\
\text { ethane }\end{array}$ & $\begin{array}{l}\text { Tetrachloro- } \\
\text { ethylene }\end{array}$ & $\begin{array}{l}\text { Trichloro- } \\
\text { ethylene }\end{array}$ \\
\hline & $04 / 25$ & $<\mathrm{dl}^{b}$ & 0.2 & $<\mathrm{dl}$ & $<\mathrm{dl}$ & $<\mathrm{dl}$ \\
\hline & $10 / 17$ & $<\mathrm{dl}$ & 0.2 & $<\mathrm{dl}$ & $<\mathrm{dl}$ & $<\mathrm{dl}$ \\
\hline \multirow[t]{2}{*}{38} & $04 / 18$ & $<\mathrm{dl}$ & $<\mathrm{dl}$ & 0.3 & $<d I$ & $<\mathrm{dl}$ \\
\hline & $10 / 14$ & $<\mathrm{dl}$ & $<$ dl & 0.3 & $<\mathrm{dl}$ & $<$ dl \\
\hline \multirow[t]{2}{*}{65} & $04 / 15$ & $<\mathrm{dl}$ & $<\mathrm{dll}$ & 0.4 & $<$ dl & $<\mathrm{dl}$ \\
\hline & $10 / 12$ & $<$ dl & $<\mathrm{dl}$ & 0.4 & $<$ dl & $<\mathrm{dl}$ \\
\hline \multirow[t]{4}{*}{87} & $01 / 10$ & 1.0 & $<\mathrm{dl}$ & 0.2 & $<\mathrm{dl}$ & 0.3 \\
\hline & $04 / 13$ & 1.3 & $<\mathrm{dl}$ & $<\mathrm{dl}$ & $<\mathrm{dl}$ & 0.4 \\
\hline & $07 / 12$ & 1.4 & $<\mathrm{dl}$ & $<d l$ & $<$ dl & 0.4 \\
\hline & $10 / 12$ & 1.3 & $\leq \mathrm{dl}$ & $<\mathrm{dl}$ & $<$ dl & 0.4 \\
\hline \multirow[t]{4}{*}{88} & $01 / 12$ & 1.5 & 0.5 & 0.2 & $<\mathrm{dl}$ & 0.8 \\
\hline & $05 / 02$ & 1.2 & 0.5 & 0.2 & $<\mathrm{dl}$ & 0.6 \\
\hline & $07 / 11$ & 1.6 & 0.4 & 0.2 & $<$ dl & 0.9 \\
\hline & $09 / 28$ & 1.7 & 0.5 & 0.2 & $<$ dl & 0.8 \\
\hline \multirow[t]{2}{*}{90} & $01 / 11$ & 1.2 & $<\mathrm{dl}$ & 0.3 & $<\mathrm{dl}$ & 0.5 \\
\hline & $05 / 02$ & 1.5 & $<\mathrm{dl}$ & 0.3 & $<\mathrm{dl}$ & 0.5 \\
\hline \multirow[t]{2}{*}{113} & $04 / 20$ & $<\mathrm{dl}$ & $<\mathrm{dl}$ & 0.3 & $<\mathrm{dl}$ & $<\mathrm{dI}$ \\
\hline & $10 / 17$ & $<$ dl & $\leq \mathrm{dl}$ & 0.3 & $<\mathrm{dl}$ & $<\mathrm{dl}$ \\
\hline \multirow[t]{2}{*}{114} & $04 / 20$ & $<\mathrm{dl}$ & $<\mathrm{dl}$ & 0.4 & $<$ dl & $<\mathrm{dl}$ \\
\hline & $10 / 13$ & $\leq \mathrm{dl}$ & $<\mathrm{dl}$ & 0.5 & $<\mathrm{dl}$ & $<\mathrm{dl}$ \\
\hline \multirow[t]{2}{*}{116} & $04 / 20$ & $<\mathrm{dl}$ & 0.3 & 0.2 & $<\mathrm{dI}$ & $<\mathrm{dl}$ \\
\hline & $10 / 13$ & $<\mathrm{dl}$ & $<\mathrm{dl}$ & $\leq \mathrm{dl}$ & $<\mathrm{dl}$ & $<\mathrm{dl}$ \\
\hline \multirow[t]{3}{*}{120} & $04 / 20$ & 0.7 & $<\mathrm{dl}$ & $<\mathrm{dl}$ & $<\mathrm{dl}$ & $<\mathrm{dl}$ \\
\hline & $07 / 11$ & 0.5 & $<\mathrm{dl}$ & $<\mathrm{dl}$ & $<\mathrm{dl}$ & $<\mathrm{dl}$ \\
\hline & $10 / 06$ & 0.6 & $<\mathrm{dl}$ & $<\mathrm{dl}$ & $<\mathrm{dl}$ & $<\mathrm{dl}$ \\
\hline \multirow{2}{*}{$\begin{array}{l}\text { Fire Stat. } \\
\quad \# 2^{c}\end{array}$} & $04 / 07$ & $<\mathrm{dl}$ & $<\mathrm{dl}$ & 1.6 & $<\mathrm{dl}$ & $<\mathrm{dl}$ \\
\hline & $10 / 06$ & $<$ d1 & $\leq \mathrm{dl}$ & 1.7 & $<\mathrm{dI}$ & $<\mathrm{dl}$ \\
\hline \multirow[t]{12}{*}{$R W M C^{c}$} & $01 / 10$ & 2.3 & 0.3 & 0.4 & $<\mathrm{dl}$ & 1.3 \\
\hline & $02 / 15$ & 3.0 & 0.4 & 0.5 & 0.2 & 1.7 \\
\hline & $03 / 15$ & 3.0 & 0.4 & 0.5 & 0.2 & 1.6 \\
\hline & $04 / 13$ & 3.0 & 0.4 & 0.5 & $<\mathrm{dl}$ & 1.5 \\
\hline & $05 / 17$ & 2.7 & 0.4 & 0.4 & $<\mathrm{dl}$ & 1.4 \\
\hline & $06 / 15$ & 3.0 & 0.4 & 0.5 & $<\mathrm{dl}$ & 1.4 \\
\hline & $07 / 14$ & 2.6 & 0.3 & 0.4 & $<\mathrm{dl} l$ & 1.2 \\
\hline & $08 / 16$ & 2.6 & 0.3 & 0.4 & $<\mathrm{dl}$ & 1.2 \\
\hline & $09 / 13$ & 2.9 & 0.3 & 0.5 & $<\mathrm{dl}$ & 1.3 \\
\hline & $10 / 12$ & 2.6 & 0.3 & 0.4 & $<\mathrm{dl}$ & 1.3 \\
\hline & $11 / 16$ & 3.1 & 0.5 & 0.5 & $<\mathrm{dl}$ & 1.5 \\
\hline & $12 / 14$ & 4.7 & 0.6 & 0.7 & 0.2 & 1.8 \\
\hline \multicolumn{2}{|c|}{$\begin{array}{c}\text { EPA maximum } \\
\text { contaminant level }\end{array}$} & 5 & 100 & 200 & 5 & 5 \\
\hline \multicolumn{7}{|c|}{$\begin{array}{l}\text { Concentrations expressed in } \mu \mathrm{g} / \mathrm{L} \text {. Only samples for } \\
\text { are included. } \\
\text { c Analytical result less than detection limit of } 0.2 \mu \mathrm{g} / \mathrm{L} \text {. } \\
\text { Production wells. }\end{array}$} \\
\hline
\end{tabular}

from the Cafeteria at TAN-678 (the Contained Test Facility) had coliform present, but the facility disinfected the drinking water lines by chlorinating, and the samples from that location have had no coliform bacteria since then. A similar situation occurred at ANL-W in
July when the chlorination system was inoperable. Subsequent samples were clear. TRA also had samples positive for coliform bacteria in July 1994. The public water system was disinfected by chlorinating, and samples from retesting were negative. The one area 
where coliform bacteria were persistently present in drinking water was at the Technical Support Facility at TAN. Coliform bacteria is believed to be due to biological regrowth. In June 1995, permanant chlorination will be installed which will eliminate the biological regrowth and ensure the water is safe for consumption.

\section{Radiological Monitoring}

All INEL contractors with liquid effluent streams containing radionuclides sample the waste streams and report the results of analyses on a monthly basis to the Radioactive Waste Management Information System operated by EG\&G/LITCO. Each quarter a report is published showing the monthly radiological releases at all INEL facilities.

In the past, major contractors sampled drinking water wells quarterly at their facilities every fourth year. These samples were then submitted for gross alpha, gross beta, and tritium analyses to an analytical laboratory either certified by the State of Idaho or by a state whose certification is accepted by the State of Idaho. In 1994, the RESL Analytical Measurements Team was certified by the State of Idaho for radiological analyses of drinking water. The EG\&G/LITCO drinking water program for 1994 fulfilled the compliance requirements for the INEL for radiological monitoring. Results of this program were discussed in Chapter 4 as part of the routine environmental surveillance program.

Argonne National Laboratory-West (ANL-W). ANL-W sampled its Industrial Waste Pond and Primary Sanitary Lagoon monthly when these ponds were unfrozen and analyzed the water for gross alpha, gross beta, tritium, and gamma-emitting radionuclides. In the October sample from the Sanitary Lagoon, gross alpha $\left(6.5 \times 10^{-9} \mu \mathrm{Ci} / \mathrm{mL}\right)$, gross beta (32 $\left.\times 10^{-9} \mu \mathrm{Ci} / \mathrm{mL}\right)$ and tritium $\left(3.1 \times 10^{-6} \mu \mathrm{Ci} / \mathrm{mL}\right)$ were above the minimum detectable concentration.

\section{Chemical Monitoring}

\section{Argonne National Laboratory-West} (ANL-W). No volatile organic compounds were found in ANL-W production well samples in 1994.

EG\&G/Lockheed Idaho Technologies Company (EG\&G/LITCO). The EG\&G/LITCO Environmental Monitoring Unit routinely samples drinking water from wells and distribution systems at facilities at the INEL for volatile organic compounds. At the Technical Service Facility at TAN (TAN/TSF), the production wells and distribution systems are sampled more frequently since the discovery in 1987 that the trichloroethylene concentrations in samples collected at the wellhead exceeded the EPA maximum contaminant level. Concentrations again exceeded the maximum contaminant level throughout 1994 (Table 5.2).

In 1988 , a corrective action plan was implemented by installing an aerating device (sparger system) at the point of entry to the distribution system to remove the volatile trichoroethylene from the drinking water in the system. The routine monitoring program, which samples the water at the wellhead and in the distribution system has indicated the aeration system works well. Drinking water samples from the TAN/TSF distribution system have generally not exceeded the regulatory levels since installation of the sparger. In 1994, the trichloroethylene in an August sample was greater than the maximum contaminant level. This was during a period when the system was 
out of service for chlorination due to the bacteria detections described previously.

A plan for remedial action to address the localized contamination in the aquifer has been developed. Monitoring and treatment will continue as long as is necessary to follow the contaminants present in the water.

Concentrations of trichloroethylene in samples from the Water Reactor Research Test Facility (WRRTF) distribution system occasionally rise above the maximum contaminant level of $5 \mu \mathrm{g} / \mathrm{L}$. However, only bottled water is used by personnel at WRRTF, so the elevated concentrations of trichloroethylene are not of health concern to employees there. Sampling at WRRTF is conducted for trend and ground-water data information. These data are not used for compliance purposes because personnel do not drink water from this inactive water system.

Chlorinated drinking water systems must also be monitored for total trihalomethanes (bromodichloromethane, bromoform, chloroform, and dibromochloromethane). The concentration in the Rifle Range well was below the reporting level. The concentration from the CFA distribution system was $4 \mu \mathrm{g} / \mathrm{L}$, or $4 \%$ of the EPA maximum contaminant level of $100 \mu \mathrm{g} / \mathrm{L}$.

During 1992, EG\&G Idaho initiated a semiannual monitoring program for lead and copper levels in drinking water in accordance with EPA regulations (40 CFR 141.80-141.91). Action levels are determined based on "90th percentile" values. An action level is exceeded if more than 10 percent of water samples collected during a six month monitoring period exceed the regulatory values $(1.3 \mathrm{mg} / \mathrm{L}$ for copper and $0.015 \mathrm{mg} / \mathrm{L}$ for lead). In 1994, the 90th percentile value was not greater than the regulatory action level for either constituent.

Additional sampling was conducted in 1994 for a variety of inorganic constituents, including metals, nitrates, dissolved solids. None of these parameters exceeded its maximum contaminant level. More detailed information and data will be included in the Drinking Water Program 1994 Annual Report, EG\&G-2678(94) which is due to be published in August 1995.

Naval Reactors Facility (NRF). Drinking water samples were collected from source water prior to entering the distribution system and monitored for volatile organic compounds, inorganic constituents, and water quality parameters. These samples were drawn from a sampling port immediately downstream from the water softening treatment system at the NRF boilerhouse. No volatile organic compounds were detected above the minimum detection levels established for the analyses of these compounds. Concentrations of inorganic analytes and water quality parameters were all below regulatory limits.

Lead and copper monitoring of the NRF drinking water system was continued in 1994 in accordance with applicable state and federal regulations. Sampling locations identified with elevated concentrations of lead in 1993 were remediated in accordance with a state-approved corrective action plan. Instances where lead was identified in drinking water appeared to be the result of lead-bearing fittings or fixtures within the distribution system, as NRF does not have any lead water lines. No action levels for copper were exceeded.

Idaho Chemical Processing Plant (ICPP). Water from the production and potable wells at the ICPP facility were analyzed monthly for a number of parameters (Table 5.3). None of these constituents were above the EPA maximum contaminant levels or State of Idaho drinking water limits during 1994. 
Table 5.2 Regulated Organic Compounds $[\mu \mathrm{g} / \mathrm{L}]$ in INEL Drinking Water (1994)

\begin{tabular}{|c|c|c|}
\hline \multicolumn{3}{|c|}{$\begin{array}{l}\text { Tetrachloroethylene } \\
\text { maximum contaminant } \\
\text {. level }=5 \mathrm{ggl} \text {. }\end{array}$} \\
\hline \multirow{8}{*}{$\begin{array}{c}\text { TAN610 } \\
\text { (TSF } \\
\text { Distribution) }\end{array}$} & \begin{tabular}{|l} 
January \\
\end{tabular} & 0.5 \\
\hline & February & 0.5 \\
\hline & March & 0.8 \\
\hline & April & 0.5 \\
\hline & May & 0.6 \\
\hline & June & 0.7 \\
\hline & July & 0.8 \\
\hline & August & 1.4 \\
\hline \multirow[t]{12}{*}{ TAN612 } & January & 2.3 \\
\hline & February & 2.8 \\
\hline & March & 2.6 \\
\hline & April & 2.2 \\
\hline & May & 2.5 \\
\hline & June & 2.6 \\
\hline & July & 2.8 \\
\hline & August & 4.7 \\
\hline & November & 3.5 \\
\hline & December & 2.8 \\
\hline & November & 3.5 \\
\hline & December & 2.6 \\
\hline \multirow[t]{9}{*}{ TAN613 } & February & 0.9 \\
\hline & March & 0.8 \\
\hline & April & 1.0 \\
\hline & May & 0.5 \\
\hline & June & 1.3 \\
\hline & July & 0.7 \\
\hline & August & 1.3 \\
\hline & September & 1.3 \\
\hline & October & 1.4 \\
\hline TAN 644 & September & 1.1 \\
\hline \multirow{2}{*}{\multicolumn{3}{|c|}{$\begin{array}{l}\text { Trichloroethylene } \\
\text { Maximum contaminant } \\
\text { level }=5 \text { jghl. }\end{array}$}} \\
\hline & & \\
\hline \multirow[t]{4}{*}{ CFA 614} & February & 0.7 \\
\hline & March & 0.8 \\
\hline & June & 0.9 \\
\hline & September & 1.0 \\
\hline \multirow{4}{*}{$\begin{array}{c}\text { CFA 641 } \\
\text { (CFA } \\
\text { Distribution) }\end{array}$} & February & 0.7 \\
\hline & April & 0.7 \\
\hline & July & 0.8 \\
\hline & October & 0.8 \\
\hline \multirow[t]{2}{*}{ CFA 642} & March & 0.9 \\
\hline & September & 1.4 \\
\hline CFA651 & March & 0.6 \\
\hline
\end{tabular}

\begin{tabular}{|c|c|c|}
\hline \multicolumn{3}{|c|}{$\begin{array}{l}\text { Trichloroethylene (Cont) } \\
\text { Maximum contaminant } \\
\text { level }=5 \mathrm{ug} / \mathrm{l} \text {. }\end{array}$} \\
\hline CFA665 & September & 1.0 \\
\hline CFA688 & \begin{tabular}{|l|} 
October \\
\end{tabular} & 1.1 \\
\hline CFA698 & September & 0.9 \\
\hline \multirow{2}{*}{$\begin{array}{c}\text { RWMC } \\
\text { WMF603 }\end{array}$} & March & 1.3 \\
\hline & September & 1.2 \\
\hline \multirow{4}{*}{$\begin{array}{c}\text { RWMC } \\
\text { Distribution }\end{array}$} & February & 0.9 \\
\hline & April & 1.0 \\
\hline & July & 0.9 \\
\hline & October & 1.0 \\
\hline \multirow{12}{*}{$\begin{array}{c}\text { TAN610 } \\
\text { (TSF } \\
\text { Distribution) }\end{array}$} & January & 2.6 \\
\hline & February & 2.9 \\
\hline & March & 3.0 \\
\hline & April & 2.2 \\
\hline & May & 3.3 \\
\hline & June & 3.1 \\
\hline & July & 3.8 \\
\hline & August & 6.0 \\
\hline & September & 1.7 \\
\hline & October & 1.9 \\
\hline & November & 2.0 \\
\hline & December & 2.3 \\
\hline \multirow[t]{10}{*}{ TAN612 } & January & 8.9 \\
\hline & February & 8.9 \\
\hline & March & 8.3 \\
\hline & April & 7.0 \\
\hline & May & 9.1 \\
\hline & June & 9.6 \\
\hline & July & 13.1 \\
\hline & August & 16.6 \\
\hline & November & 14.7 \\
\hline & December & 12.1 \\
\hline \multirow[t]{9}{*}{ TAN613 } & February & 2.5 \\
\hline & March & 2.2 \\
\hline & April & 3.0 \\
\hline & May & 1.4 \\
\hline & June & 2.6 \\
\hline & July & 3.1 \\
\hline & August & 4.3 \\
\hline & September & 4.7 \\
\hline & October & 6.1 \\
\hline TAN644 & September & 1.1 \\
\hline $\begin{array}{c}\text { TAN 645 } \\
\text { (WRRTF } \\
\text { Distribution) }\end{array}$ & September & 11.5 \\
\hline
\end{tabular}

\begin{tabular}{|c|c|c|}
\hline \multicolumn{3}{|c|}{$\begin{array}{l}\text { Ethylbenzene } \\
\text { Maximum contaminant } \\
\text { evel }=700 \text { ug } / \mathrm{L}\end{array}$} \\
\hline CFA614 & September & 14.1 \\
\hline CFA665 & September & 19.1 \\
\hline CFA698 & September & 30.7 \\
\hline \multicolumn{3}{|c|}{$\begin{array}{l}\text { Tolvene } \\
\text { Maximum contaminant } \\
\text { level =1000 vglL. }\end{array}$} \\
\hline CFA698 & September & 0.6 \\
\hline \multicolumn{3}{|c|}{$\begin{array}{l}\text { Xylenes (total) } \\
\text { Maximum contaminant } \\
\text { level }=10000 \text { Lg/L. }\end{array}$} \\
\hline CFA614 & September & 4.1 \\
\hline CFA665 & September & 20.4 \\
\hline CFA688 & September & 1.1 \\
\hline CFA698 & September & 28.1 \\
\hline \multicolumn{3}{|c|}{$\begin{array}{l}\text { p-Dichlorobenzene } \\
\text { Maximum contaminant } \\
\text { level }=75 \mathrm{ug} L \text {. }\end{array}$} \\
\hline $\begin{array}{l}\text { Main Gate } \\
\text { Distribution }\end{array}$ & July & 0.7 \\
\hline \multicolumn{3}{|c|}{$\begin{array}{l}\text { Carbon Tetrachloride } \\
\text { Maximum contaminant } \\
\text { Ievel }=5 \text { uglL }\end{array}$} \\
\hline \multirow{2}{*}{$\begin{array}{c}\text { RWMC } \\
\text { WMF603 }\end{array}$} & March & 2.3 \\
\hline & September & 3.1 \\
\hline \multirow{4}{*}{$\begin{array}{c}\text { RWMC } \\
\text { Distribution }\end{array}$} & February & 1.5 \\
\hline & April & 1.4 \\
\hline & & 1.7 \\
\hline & October & 2.5 \\
\hline \multicolumn{3}{|c|}{$\begin{array}{l}1,1,1 \text {-Tichloroethane } \\
\text { Maximum contaminant } \\
\text { Ievel }=200 \mathrm{Lg} / \mathrm{L} \text {. }\end{array}$} \\
\hline \multirow{3}{*}{$\begin{array}{l}\text { Main Gate } \\
\text { Distribution }\end{array}$} & February & 1.1 \\
\hline & July & 1.2 \\
\hline & October & 1.4 \\
\hline \multirow{3}{*}{$\begin{array}{c}\text { Main Gate } \\
605\end{array}$} & March & 1.0 \\
\hline & April & 0.9 \\
\hline & September & 1.3 \\
\hline $\begin{array}{c}\text { TAN 645 } \\
\text { (WRRTF } \\
\text { Distribution }\end{array}$ & September & 4.2 \\
\hline
\end{tabular}




\begin{tabular}{|c|c|c|c|c|c|c|c|c|c|c|c|c|c|}
\hline \multirow[b]{2}{*}{$\forall / N$} & \multicolumn{4}{|c|}{ 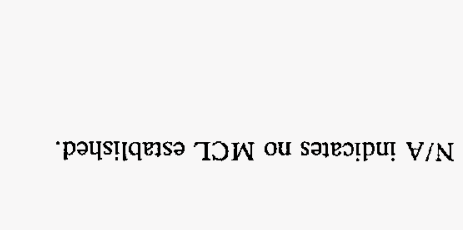 } & \multicolumn{9}{|c|}{ 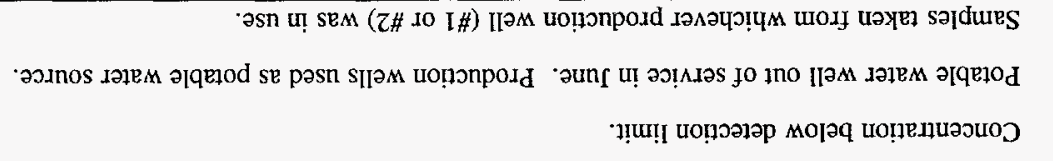 } \\
\hline & 092 & $6 \varsigma 2$ & $9: 22$ & 0.82 & \multirow{2}{*}{$\begin{array}{l}\llcorner .9 Z \\
i p>\end{array}$} & \multirow{2}{*}{$\begin{array}{l}6 . t 2 \\
I p>\end{array}$} & \multirow{2}{*}{$\begin{array}{l}L 92 \\
{[p>}\end{array}$} & \multirow{2}{*}{$\begin{array}{l}192 \\
{[\mathrm{p}>}\end{array}$} & \multirow{3}{*}{$\begin{array}{l}892 \\
1 \mathrm{p}> \\
79^{\circ} t\end{array}$} & \multirow{3}{*}{$\begin{array}{l}I \cdot L Z \\
I P> \\
t 8 \cdot t\end{array}$} & \multirow{3}{*}{$\begin{array}{l}L S \mathcal{Z} \\
\mathrm{IP}> \\
\mathrm{s} \downarrow\end{array}$} & \multirow{3}{*}{$\begin{array}{l}+\varepsilon \tau \\
{[p>} \\
89^{\circ} \dagger\end{array}$} & \multirow{2}{*}{$\begin{array}{c}\text { ә1вIInS } \\
\text { әнеydsoyd }\end{array}$} \\
\hline$\forall / N$ & $\mathrm{IP}>$ & $\mathrm{lp}>$ & $\mathrm{Ip}>$ & $\mathrm{Ip}>$ & & & & & & & & & \\
\hline 01 & t9t & $s 9^{\circ} t$ & $\varepsilon L^{\prime} t$ & $S L{ }^{\circ}$ & $\varepsilon 8^{\circ} t$ & $\varsigma \varsigma^{*} t$ & $16 t$ & $L S t$ & & & & & วุEIIIN \\
\hline$t$ & $0 z 0$ & {$[\mathrm{p}>$} & $I \mathrm{IP}>$ & $0 z 0$ & 120 & $\varepsilon \tau^{*} 0$ & $I Z \cdot 0$ & $0 \overrightarrow{2} 0$ & 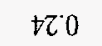 & $\varepsilon z 0$ & Ip> & $z 2 \cdot 0$ & әр!.on」н \\
\hline$\forall / N$ & $0.9 \mathrm{I}$ & $L: L I$ & $z \cdot 0 z$ & $8 \cdot 8 I$ & $6 \angle \mathrm{LI}$ & $I \angle I$ & 802 & 781 & $9 \cdot L I$ & โ'8I & $S L I$ & +81 & әр!ло|чว \\
\hline$\forall / N$ & 1.8 & $S: L$ & $8 L$ & $\varepsilon L$ & $8 L$ & $\varepsilon L$ & $O L$ & $\tau L$ & $\tau / L$ & $8 . L$ & $\varepsilon 8$ & 0.8 & un!̣pos \\
\hline$\forall / N$ & $\mathrm{IP}>$ & Ip> & Ip $>$ & Ip> & {$[p>$} & {$[\mathrm{p}>$} & {$[p>$} & Ip> & Ip> & Ip> & Ip> & Ip> & 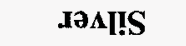 \\
\hline$S_{00}$ & $\mathcal{E} 00^{\circ} 0$ & Ip> & IP> & $i p>$ & ips & $|p\rangle$ & {$[p>$} & {$[\mathrm{p}>$} & IP> & Ip $>$ & Ip> & Ip> & un!̣uว|PS \\
\hline $\mathfrak{S}_{0}^{\circ} 0$ & $\mathrm{Ip}>$ & IP> & Ip> & $\mathrm{Ip}>$ & Ip> & Ip> & Ip> & {$[\mathrm{p}>$} & Ip> & lp> & Ip> & Ip> & К.xnว.JวW \\
\hline$s_{0}^{\circ}$ & Ip> & Ip> & Ip> & {$[p>$} & IP> & Ip> & Ip> & Ip> & $\angle 000$ & Ip> & Ip> & Ip> & рвәт \\
\hline$\lceil\cdot 0$ & 5000 & $900^{\circ} 0$ & 9000 & $500^{\circ} 0$ & $\angle 00^{\circ}$ & 9000 & 9000 & 9000 & 9000 & $900^{\circ} 0$ & $500^{\circ} 0$ & soo.0 & นun!̣uroมบ \\
\hline $5000^{\circ}$ & $I p>$ & {$[p>$} & $1 p>$ & {$[p>$} & $I p>$ & {$[\mathrm{p}>$} & $8000^{\circ} 0$ & $5000^{\circ} 0$ & $6000^{\circ} 0$ & $I p>$ & {$[\mathrm{p}>$} & [p> & un!̣upe- \\
\hline$\tau$ & 600 & 600 & 600 & $60 \%$ & $80^{\circ} 0$ & 600 & 800 & $80^{\circ} 0$ & $80^{\circ} 0$ & 600 & 600 & 600 & un!.IBg \\
\hline so: & IP> & $\lfloor p>$ & $1 p>$ & [P> & $\lfloor p>$ & 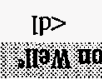 & Ip> & $\llbracket p>$ & $\mathrm{Ip>}$ & {$[p>$} & {$[\mathrm{p}>$} & IP> & ग̣uas.x \\
\hline $\mathrm{V} / \mathrm{N}$ & 092 & $\varsigma \varsigma \mathcal{L}$ & $I \subseteq Z$ & $\tau: L$ & $L \nabla z$ & $9^{\circ} 92$ & SN & $\angle 97$ & $6 S Z$ & 782 & $\varepsilon \angle Z$ & I'sZ & วิ8JInS \\
\hline$\forall / N$ & $\mathrm{Ip}>$ & $\mathrm{IP}>$ & $\mathrm{IP}>$ & Ip> & {$[\mathrm{p}>$} & Ip> & SN & $\mathrm{IP}>$ & $\tau L O$ & $\mathrm{IP}>$ & Ip $>$ & $\mathrm{IP}>$ & әңвपdsoyd \\
\hline 01 & $\varepsilon L \cdot t$ & 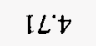 & $L L^{\circ}$ & $0 S^{\circ}$ & $68^{\circ} 7$ & $\varepsilon 9^{\circ} t$ & SN & $\varepsilon \varsigma \triangleright$ & $69^{\circ} t$ & $L L D$ & $29^{\circ} t$ & $29^{\circ}$ & әุEdโIN \\
\hline$t$ & $I Z 0$ & $\mathrm{IP}>$ & or 0 & 120 & $I Z 0$ & $I Z 0$ & SN & $\tau \tau 0$ & $\varepsilon Z \cdot 0$ & 220 & {$[\mathrm{p}>$} & $\varepsilon z \cdot 0$ & әp!.10nIS \\
\hline$\nabla / N$ & 091 & $8 \cdot 81$ & $0.8 \mathrm{I}$ & $\varepsilon \angle I$ & $\varepsilon L I$ & $00 z$ & SN & I'8I & $\nabla L L I$ & L.6I & $L \angle L I$ & $I \cdot L I$ & әр!ుоІчว \\
\hline$\forall / N$ & 66 & $S L$ & $\nabla L$ & $\varepsilon L$ & $\varepsilon L$ & $\varsigma L$ & SN & $\nabla^{\prime} L$ & $\varepsilon 8$ & 0.8 & $\varepsilon 8$ & $L L$ & unn!̣os \\
\hline$\tau$ & Ip> & Ip> & Ip> & Ip> & Ip> & {$[\mathrm{p}>$} & SN & Ip> & Ip> & Ip> & Ip> & {$[\mathrm{p}>$} & גəАIIS \\
\hline$S_{0} 0$ & $\mathrm{IP}>$ & Ip> & $\mid p>$ & Ip> & Ip> & Ip> & SN & Ip> & Ip> & Ip> & Ip> & $\angle 00^{\circ} 0$ & un!̣uวןas \\
\hline $200^{\circ} 0$ & Ip> & Ip> & $\mathrm{Ip}>$ & $\mathrm{Ip}>$ & Ip> & Ip> & $\mathrm{SN}$ & $\mathrm{Ip}>$ & Ip> & $\mathrm{IP}>$ & {$[\mathrm{p}>$} & Ip> & К.Jnว.มаW \\
\hline$S 0^{\circ} 0$ & Ip> & IP> & $\mathrm{IP}>$ & {$[p>$} & $\mid \mathrm{p}>$ & {$[\mathrm{p}>$} & $\mathrm{SN}$ & $\mid p>$ & $\mathrm{IP}>$ & Ip> & $\mathrm{Ip}>$ & Ip> & рвәт \\
\hline$I \cdot 0$ & $\angle 00^{\circ} 0$ & $\angle 00^{\circ} 0$ & $\varsigma 00^{\circ} 0$ & t00 0 & $\varepsilon 00^{\circ} 0$ & $900^{\circ} 0$ & SN & 9000 & $\$ 00^{\circ} 0$ & $900^{\circ} 0$ & 9000 & $900^{\circ} 0$ & un!̣ய0.14ว \\
\hline$S 00^{\circ} 0$ & $\mathrm{IP}>$ & {$[\mathrm{p}>$} & $\mathrm{IP}>$ & Ip $>$ & [p> & {$[p>$} & SN & $500^{\circ} 0$ & Ip> & {$[\mathrm{p}>$} & [p> & Ip> & urn!upe \\
\hline$\tau$ & $\varepsilon 00^{\circ} 0$ & 600 & 600 & 600 & 600 & 600 & SN & $60^{\circ} 0$ & $80^{\circ} 0$ & $800^{\circ}$ & $60 \%$ & 600 & un!̣.IEg \\
\hline SO० 0 & $\mathrm{IP}>$ & $\mathrm{Ip}>$ & {$[\mathrm{p}>$} & $\mathrm{Ip}>$ & {$[\mathrm{p}>$} & Ip> & ${ }_{\mathrm{p} S N}$ & Ip> & $\mathrm{Ip}>$ & {$[\mathrm{p}>$} & $\mathrm{IP}>$ & I $\mathrm{p}>$ & ग̣uวS.I V \\
\hline$\overline{q 75 \%}$ & $\overline{ग ् 0 ~}$ & $\overline{n O N}$ & $\overline{100}$ & dब्s & हnच & $\overline{n n}$ & une & ХEW & $\overline{d a t}$ & $\overline{d e W}$ & 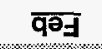 & $\overline{\mathrm{uer}}$ & \\
\hline $17: 0$ & $(t 66$ & STI' & $\Lambda$ NOI & Pndo & Ud O & E'S & $\begin{array}{l}\text { LOd } \\
\text { gVLL }\end{array}$ & IOI N & STVD & NHH & $3 .: 0$. & $\mathbf{X O N}$ & \\
\hline
\end{tabular}




\section{ENVIRONMENTAL NONRADIOLOGICAL PROGRAM INFORMATION}

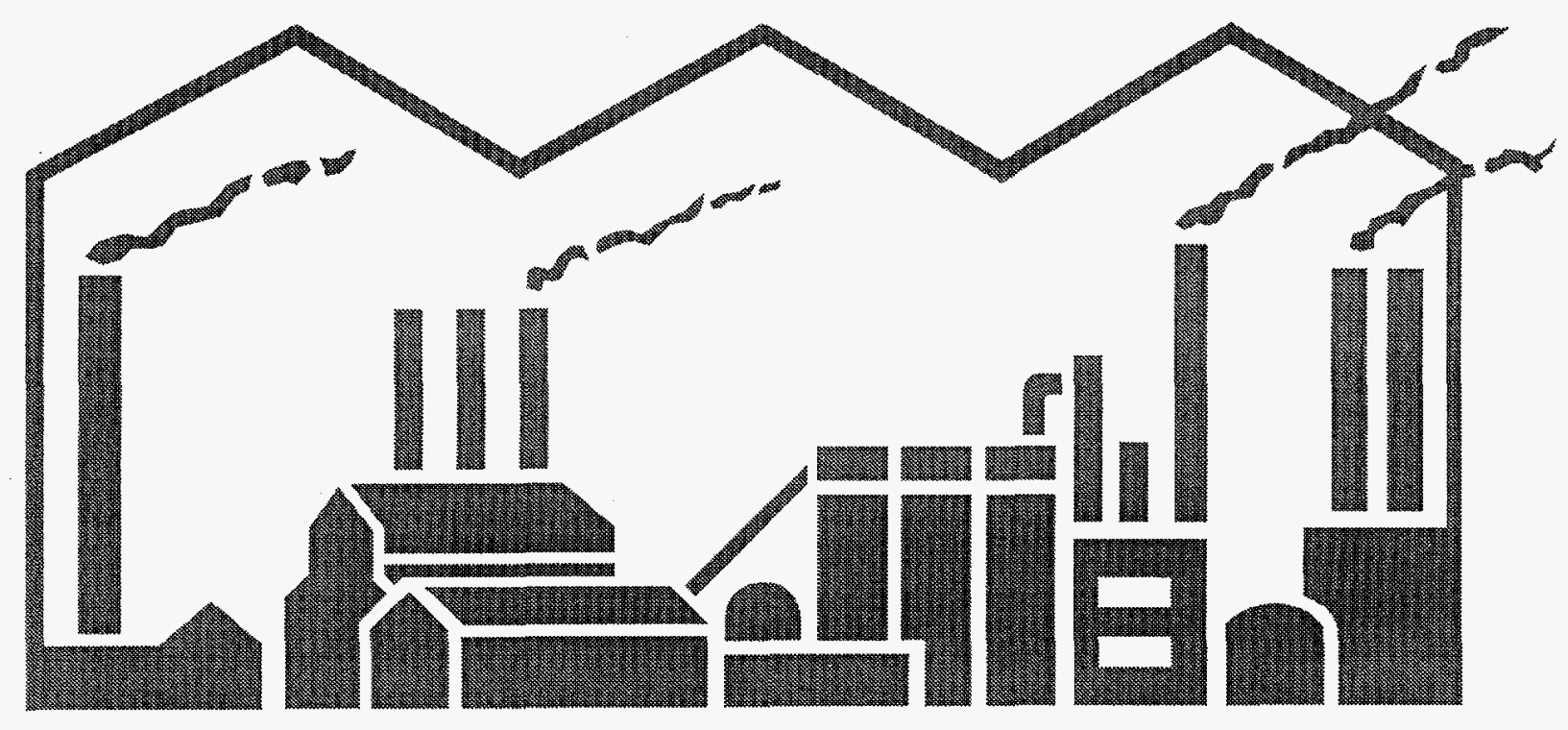





\section{ENVIRONMENTAL NONRADIOLOGICAL PROGRAM INFORMATION}

\subsection{ENVIRONMENTAL SURVEILLANCE PROGRAM DESCRIPTION}

\section{Total Suspended Particulates}

Measurements of total suspended particulates were performed on the particulate filters from the low-volume filters described in Chapter 4. The Foundation weighed clean filters at the beginning of each quarter and weighed filter composites at the end of the quarter. EG\&G/LITCO weighed individual filters at the start and end of sampling each week. The concentration of total suspended particulates was calculated by dividing the amount of material collected on the filters by the total volume of air passing though the filters.

The EPA primary and secondary standard for particulate matter is $50 \mu \mathrm{g} / \mathrm{m}^{3}$, but it applies only to "particulates with an aerodynamic diameter less than or equal to a nominal 10 micrometers." Measurements of total suspended particulates will overestimate particulate concentrations in the $10 \mu \mathrm{m}$ and below size range in comparison with the new standard. This is because the standard applies only to particles on the filter with diameters of $10 \mu \mathrm{m}$ or less, but many of the particles on the low-volume filters are actually larger than that size because there is no device on the samplers to screen out the larger particles. Particles larger than $10 \mu \mathrm{m}$ are not considered by the EPA to be respirable by humans because they do not usually enter the lungs with inhaled air. The larger particles usually fall out before they reach the nose, are trapped by nasal hairs, or are impacted on tissues of the nasopharynx and passed through the body via the digestive system.

\section{IMPROVE Samplers}

In May of 1992, one sampler was established at the Central Facilities Area on the INEL and a second was located at Craters of the Moon National Monument as part of the NPS IMPROVE (National Park Service Interagency Monitoring of Protected Visual Environments) aerosol network. This network has been in operation since March 1988 at national parks, monuments, and wilderness areas across the United States. Funding for the operation of the Craters of the Moon sampler is provided under a Memorandum of Understanding between the DOE and the National Park Service.

The two samplers, comprised only of Module A of the complete IMPROVE sampler (which may contain up to four modules), each collected two 24-hr samples weekly of fine particulates $(<2.5 \mu \mathrm{m}$ in diameter). Analyses for mass, optical absorption, hydrogen, carbon, nitrogen, and oxygen plus elements from sodium through lead on the Periodic Table were performed by Crocker Nuclear Laboratory at the University of California in Davis, California.

\section{Nitrogen Dioxide/Sulfur Dioxide Monitoring}

To fulfill one of the conditions specified in the Permit to Construct the Fuel Processing Restoration facility, two nitrogen oxide monitoring stations (which measure $\mathrm{NO}$ and $\mathrm{NO}_{2}$, collectively called $\mathrm{NO}_{\mathrm{x}}$ ) were operated by EG\&G/LITCO. These were located near the intersection of US Highway 20/26 and Van 
Buren Boulevard (VANB) and at the Experimental Field Station. The analyzers used are designated as EPA equivalent methods.

One sulfur dioxide $\left(\mathrm{SO}_{2}\right)$ analyzer (also designated as an EPA equivalent method) was operated at the VANB location in addition to the nitrogen dioxide analyzer.

\subsection{ENVIRONMENTAL SURVEILLANCE PROGRAM RESULTS}

\section{Total Suspended Particulates}

Results for 1994 indicated the annual mean of quarterly total suspended particulate concentrations at offsite locations ranged from $11 \mu \mathrm{g} / \mathrm{m}^{3}$ at the FAA Tower to $52 \mu \mathrm{g} / \mathrm{m}^{3}$ at Idaho Falls (Table 6.1). To allow comparison with the data from the Foundation's offsite samplers, the weekly EG\&G/LITCO particulate data were converted to quarterly values. The EG\&G/LITCO onsite mean total suspended particulate concentration of $25 \mu \mathrm{g} / \mathrm{m}^{3}$ was similar to the Foundation's distant mean of 28 $\mu \mathrm{g} / \mathrm{m}^{3}$ and the boundary mean of $23 \mu \mathrm{g} / \mathrm{m}^{3}$. The largest source of airborne particulates in the vicinity of the INEL is considered to be resuspended dust from agricultural operations. Total suspended particulate concentrations for 1985-1994 are provided in Table 6.2.

\section{IMPROVE Samplers}

Data were available for the period June 1992 through May 1994. A summary of results obtained during this time period is shown in Table 6.3.

\section{Nitrogen Dioxide}

The New Waste Calcining Facility at ICPP, the largest single source of nitrogen dioxide on the INEL, did not operate during
1994. Mean nitrogen dioxide concentrations for 1994 were $15.4 \mu \mathrm{g} / \mathrm{m}^{3}$ (8.2 parts per billion) at EFS and $4.9 \mu \mathrm{g} / \mathrm{m}^{3}$ (2.6 parts per billion) at VANB, lower than the EPA national primary ambient air quality standard of $100 \mu \mathrm{g} / \mathrm{m}^{3}$. Data recovery for the year was about $62 \%$ at Van Buren and $70 \%$ at EFS. Data were not collected during most of the second quarter at each location due to malfunction of the data recording systems. A new recording system was installed at the beginning of the third quarter.

\section{Sulfur Dioxide}

The mean $\mathrm{SO}_{2}$ concentration for 1994 was $2.7 \mu \mathrm{g} / \mathrm{m}^{3}$ (1.0 parts per billion), or $3 \%$ of the annual primary air quality standard. The maximum daily concentration of $8.8 \mu \mathrm{g} / \mathrm{m}^{3}(3.3$ parts per billion) on February 16 was $2 \%$ of the primary standard for a 24 -hour period. The maximum recorded three-hour average of 14.4 $\mu \mathrm{g} / \mathrm{m}^{3}$ (5.4 parts per billion), on January 7 , was $1.1 \%$ of the EPA secondary standard. The analyzer operated satisfactorily for about $64 \%$ of the year.

\subsection{NONRADIOLOGICAL AIRBORNE EFFLUENTS}

\section{Summary}

Nonradioactive airborne effluents originate from five primary sources at the INEL: (a) calcination of high-level radioactive liquid waste at the New Waste Calcining Facility (NWCF); (b) combustion of coal for steam generation at the Coal-Fired Steam Generating Facility (CFSGF); (c) combustion of fuel oil for heating at all INEL facilities; (d) motor vehicle exhausts; and (e) fugitive dusts from waste burial and construction activities. 


\begin{tabular}{|c|c|c|c|}
\hline \multicolumn{4}{|c|}{$\begin{array}{l}\text { TABLE 6.1 } \\
\text { PARTICULATE MATTER CONCENTRATIONS IN AIR (1994) }\end{array}$} \\
\hline \multirow[b]{2}{*}{ Group } & \multirow[b]{2}{*}{ Location } & \multicolumn{2}{|c|}{ Concentration $\left(\mu \mathrm{g} / \mathrm{m}^{3}\right)$} \\
\hline & & Range & Mean $^{a}$ \\
\hline \multirow[t]{5}{*}{ Distant } & Blackfoot & $9-37$ & $21 \pm 21$ \\
\hline & Craters of the Moon & $1-20$ & $12 \pm 15$ \\
\hline & Idaho Falls & $18-93$ & $52 \pm 57$ \\
\hline & Rexburg & $13-39$ & $26 \pm 17$ \\
\hline & & Grand Mean & $28 \pm 28$ \\
\hline \multirow[t]{8}{*}{ Boundary } & Arco & $20-48$ & $33 \pm 19$ \\
\hline & Atomic City & $6-46$ & $22 \pm 29$ \\
\hline & FAA Tower & $5-18$ & $11 \pm 10$ \\
\hline & Howe & $12-57$ & $30 \pm 31$ \\
\hline & Monteview & $11-47$ & $23 \pm 26$ \\
\hline & Mud Lake & $17-32$ & $24 \pm 10$ \\
\hline & Reno Ranch & $5-26$ & $\underline{17 \pm 16}$ \\
\hline & & Grand Mean ${ }^{a}$ & $23 \pm 7$ \\
\hline \multirow[t]{13}{*}{ INEL } & ANL-W & $9-39$ & $24 \pm 19$ \\
\hline & ARA & $10-33$ & $19 \pm 16$ \\
\hline & CFA & $10-31$ & $23 \pm 16$ \\
\hline & EBR-1 & $9-33$ & $20 \pm 16$ \\
\hline & EFS & $8-46$ & $28 \pm 31$ \\
\hline & ICPP & $12-24$ & $17 \pm 9$ \\
\hline & NRF & $16-60$ & $30 \pm 32$ \\
\hline & PBF & $23-67$ & $43 \pm 35$ \\
\hline & RWMC & $11-48$ & $28 \pm 24$ \\
\hline & TAN & $13-45$ & $26 \pm 23$ \\
\hline & TRA & $11-43$ & $23 \pm 22$ \\
\hline & VANB & $13-35$ & $21 \pm 15$ \\
\hline & & Grand Mean ${ }^{a}$ & $25 \pm 4$ \\
\hline
\end{tabular}

Nitrogen oxide emissions are routinely monitored by WINCO/LITCO at the New Waste Calcining Facility, and sulfur dioxide, nitrogen oxides, and carbon oxides are monitored at the CFSGF. (Both facilities are located at ICPP.) These monitoring data are published in the INEL Nonradiological Waste Management Information System (INWMIS) quarterly reports.

DOE calculates the maximum sulfur dioxide and nitrogen dioxide concentrations at the INEL boundary each year using the total annual discharges as reported by the INWMIS and the MESODIF air dispersion model. The calculational method is essentially the same as described in the section "Evaluation of Potential Radiation Dose to the Public," using mass units for releases instead of radioactivity units.

Emissions of sulfur dioxide from heating oils are calculated from sulfur content and the amount of fuel used at all INEL facilities and are reported to the INWMIS. DOE 


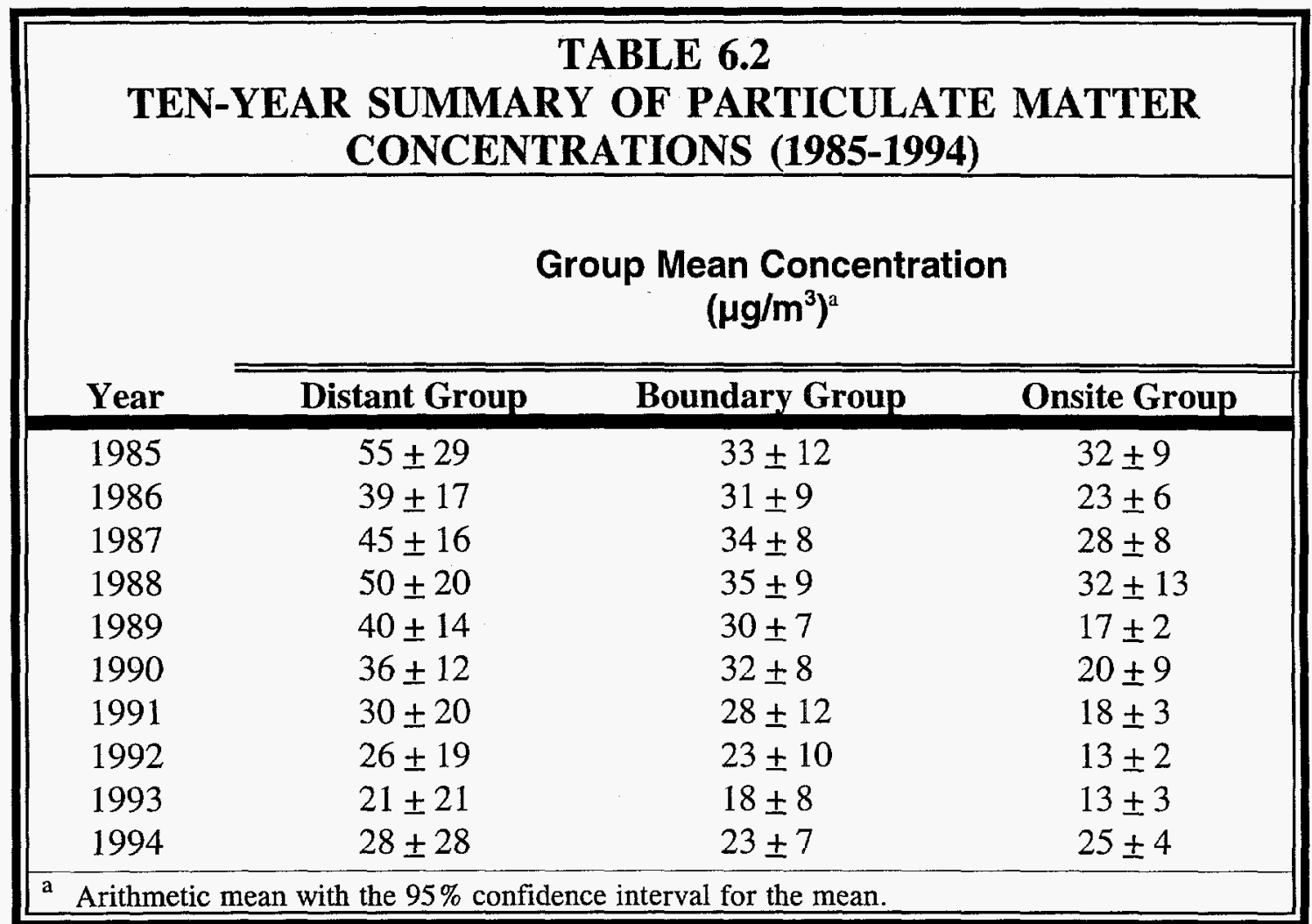

calculates emissions of nitrogen oxides from fuel by using emission factors developed by the EPA $^{\mathrm{a}}$ and the amount and type of fuel burned at each facility as reported by the LNWMIS. Motor vehicle exhausts and fugitive dusts are not monitored at their sources.

Total sulfur dioxide released in 1994 was about 188 megagrams (Mg) (Table 6.4). A $\mathrm{Mg}$ is sometimes referred to as a metric ton and is equivalent to 2200 pounds. The maximum concentration of sulfur dioxide at the southern INEL boundary, where the MESODIF model predicted the highest concentration, was $0.7 \mu \mathrm{g} / \mathrm{m}^{3}$, which is $0.9 \%$ of the national primary ambient air quality standard of 80 $\mu \mathrm{g} / \mathrm{m}^{3}$.
The releases of nitrogen oxides during 1994 are also shown in Table 6.4. When the nitrogen oxide was converted to nitrogen dioxide, the total released equaled about 100 $\mathrm{Mg}$. The calculated maximum Site boundary concentration of nitrogen dioxide was $0.4 \mu \mathrm{g} / \mathrm{m}^{3}$ from all INEL sources. This concentration is $0.4 \%$ of the national primary ambient air quality standard of $100 \mu \mathrm{g} / \mathrm{m}^{3}$.

\section{Argonne National Laboratory-West}

At ANL-W, the Experimental Breeder Reactor II Auxiliary Boilers do not require continuous monitoring because they are below 


\begin{tabular}{|c|c|c|c|c|c|c|}
\hline \multirow[b]{3}{*}{ Constituent } & \multicolumn{5}{|c|}{$\begin{array}{l}\text { TABLE 6.3 } \\
\text { DATA FOR IMPROVE SAMPLERS AT CFA AND } \\
\text { CRATERS OF THE MOON NATIONAL MONUMENT } \\
\text { (JUNE } 1992 \text { - May 1994) }\end{array}$} & \\
\hline & \multicolumn{2}{|c|}{$\%$ Detected $^{b}$} & \multicolumn{2}{|c|}{ Range } & \multicolumn{2}{|c|}{ Mean $^{c}$} \\
\hline & CFA & Craters & CFA & Craters & CFA & Craters \\
\hline Hydrogen & 100 & 100 & $42-1256$ & $37-601$ & $175 \pm 19$ & $144 \pm 11$ \\
\hline Sodium & 52 & 61 & $<\mathrm{dl}^{\mathrm{d}}-214$ & $<\mathrm{dl}-169$ & $39 \pm 6$ & $46 \pm 5$ \\
\hline Magnesium & 45 & 37 & $<\mathrm{dl}-399$ & $<\mathrm{dl}-145$ & $17 \pm 4$ & $15 \pm 3$ \\
\hline Aluminum & 78 & 78 & $<$ dl - 978 & $<\mathrm{dl}-964$ & $51 \pm 12$ & $60 \pm 12$ \\
\hline Silicon & 100 & 100 & $8-2470$ & $<\mathrm{dl}-2115$ & $144 \pm 30$ & $150 \pm 26$ \\
\hline Phosphorus & 15 & 8 & $<\mathrm{dl}-56$ & $<\mathrm{dl}-46$ & $4.2 \pm 1.0$ & $3.1 \pm 0.6$ \\
\hline Sulfur & 100 & 100 & $42-1509$ & $45-617$ & $224 \pm 22$ & $184 \pm 13$ \\
\hline Chlorine & 7 & 6 & $<\mathrm{dl}-35$ & $<\mathrm{dl}-8$ & $2.6 \pm 0.5$ & $2.4 \pm 0.1$ \\
\hline Potassium & 100 & 100 & $2-432$ & $4-298$ & $38 \pm 7$ & $36 \pm 5$ \\
\hline Calcium & 100 & 100 & $3-880$ & $3-295$ & $49 \pm 10$ & $45 \pm 6$ \\
\hline Titanium & 77 & 84 & $<\mathrm{dl}-49$ & $<\mathrm{dl}-48$ & $3.6 \pm 0.6$ & $4.3 \pm 0.6$ \\
\hline Vanadium & 32 & 26 & $<\mathrm{dl}-5.1$ & $<\mathrm{dl}-4.8$ & $1.0 \pm 0.1$ & $0.9 \pm 0.1$ \\
\hline Chromium & 29 & 24 & $<\mathrm{dl}-3.3$ & $<\mathrm{dl}-3.1$ & $0.68 \pm 0.05$ & $0.73 \pm 0.04$ \\
\hline Manganese & 50 & 55 & $<\mathrm{dl}-10$ & $<\mathrm{dl}-11$ & $1.1 \pm 0.1$ & $1.1 \pm 0.1$ \\
\hline Iron & 100 & 100 & $2-518$ & $2-410$ & $32 \pm 6$ & $35 \pm 6$ \\
\hline Nickel & 22 & 22 & $<\mathrm{dl}-0.4$ & $<\mathrm{dl}-1.1$ & $0.07 \pm 0.01$ & $0.08 \pm 0.01$ \\
\hline Copper & 99. & 96 & $<\mathrm{dl}-6$ & $<\mathrm{dl}-6$ & $0.7 \pm 0.1$ & $0.6 \pm 0.1$ \\
\hline Zinc & 100 & 100 & $0.1-29$ & $0.1-20$ & $1.8 \pm 0.3$ & $1.6 \pm 0.2$ \\
\hline Arsenic & 39 & 38 & $<\mathrm{dl}-1.7$ & $<\mathrm{dl}-4 . \mathrm{l}$ & $0.20 \pm 0.02$ & $0.21 \pm 0.04$ \\
\hline Lead & 100 & 100 & $<\mathrm{dl}-2.1$ & $<\mathrm{dl}-4.4$ & $0.59 \pm 0.05$ & $0.61 \pm 0.06$ \\
\hline Selenium & 86 & 67 & $<\mathrm{d} 1-1.2$ & $<\mathrm{dl}-0.7$ & $0.20 \pm 0.02$ & $0.15 \pm 0.02$ \\
\hline Bromine & 100 & 100 & $0.2-5$ & $0.2-5$ & $1.4 \pm 0.1$ & $1.3 \pm 0.1$ \\
\hline Rubidium & 63 & 60 & $<\mathrm{dl}-1.4$ & $<\mathrm{dl}-1.1$ & $0.12 \pm 0.02$ & $0.14 \pm 0.02$ \\
\hline Strontium & 77 & 78 & $<\mathrm{dl}-3.2$ & $<\mathrm{dl}-2.0$ & $0.23 \pm 0.04$ & $0.26 \pm 0.04$ \\
\hline Zirconium & 32 & 35 & $<\mathrm{dl}-1.3$ & $<\mathrm{dl}-1.3$ & $0.15 \pm 0.02$ & $0.16 \pm 0.02$ \\
\hline Molybdenum & 8 & 9 & $<\mathrm{dl}-3.3$ & $<\mathrm{dl}-3.8$ & $1.44 \pm 0.05$ & $1.55 \pm 0.06$ \\
\hline $\begin{array}{l}\text { anits expres } \\
\text { " Percentage o } \\
\text { Arithmetic m } \\
\text { At least one }\end{array}$ & $\operatorname{gran}$ & ce inter & mean. & at paramete & & \\
\hline
\end{tabular}

the State of Idaho's 250 million BTU/hr monitoring limit. The boiler emissions are monitored monthly as an efficiency check and to ensure that $\mathrm{NO}_{\mathrm{x}}$ and $\mathrm{SO}_{2}$ levels are below State-imposed emission limits. Personnel use a portable stack emission monitor that gives a direct printout of ambient and stack temperature, carbon monoxide, carbon dioxide, sulfur dioxide, nitrogen oxides, and oxygen. If any parameter is measured outside prescribed limits, the boiler is checked for improper operation and corrective action is initiated. During 1994, the $\mathrm{NO}_{\mathrm{x}}$ analyses ranged from 34 to $238 \mathrm{mg} / \mathrm{m}^{3}$ (18 to 126 parts per million) and
$\mathrm{SO}_{2}$ ranged between 40 and $149 \mathrm{mg} / \mathrm{m}^{3}$ (15 and 56 parts per million).

\section{Specific Manufacturing Capability (SMC) Facility}

At the Specific Manufacturing Capability facility, nonradiological airborne effluents include particulate matter, nitrogen oxides, sulfur dioxide, carbon monoxide, volatile organic compounds and toxic air pollutants. Personnel at the facility have determined that particulate matter originates from combustion sources, manufacturing processes, emergency 


\begin{tabular}{|c|c|c|c|c|c|c|c|c|c|c|}
\hline \multicolumn{11}{|c|}{$\begin{array}{c}\text { TABLE 6.4 } \\
\text { SUMMARY OF } \mathrm{NO}_{2} \text { AND } \mathrm{SO}_{2} \text { EMISSIONS AND AMBIENT } \\
\text { MONITORING RESULTS (1990-1994) }\end{array}$} \\
\hline \multirow{2}{*}{ Facility } & \multicolumn{4}{|c|}{$\mathrm{Mg} \mathrm{NO}$} & & \multicolumn{5}{|c|}{$\mathrm{Mg} \mathrm{SO}_{2}$} \\
\hline & 1990 & 1991 & 1992 & 1993 & 1994 & 1990 & 1991 & 1992 & 1993 & 1994 \\
\hline ANL-W & 4 & 3 & 5 & 6 & 5 & 6 & 8 & 10 & 13 & 15 \\
\hline CFA & 2 & 1 & 1 & 2 & 1 & 4 & 3 & 3 & 5 & 3 \\
\hline CTF & -- & -- & --- & -- & --- & 1 & $\sim$ & -- & -- & -- \\
\hline ICPP (CFSGF) & 83 & 22 & 107 & 87 & 57 & 18 & 5 & 17 & 9 & 4 \\
\hline ICPP (oil) & 1 & 13 & 2 & 6 & 10 & 6 & 86 & 14 & 44 & 71 \\
\hline ICPP (main stack) & 71 & 501 & 5 & 467 & --- & -.. & $\cdots$ & -- & $-\cdots$ & -- \\
\hline NRF & 18 & 17 & 17 & 18 & 13 & 52 & 10 & 45 & 40 & 60 \\
\hline PBF & - & $-\cdots$ & $-\cdots$ & -- & --- & 1 & 1 & 1 & -- & --- \\
\hline SMC & -- & -- & 3 & 5 & 4 & --- & -- & 8 & 11 & 9 \\
\hline TRA & 4 & 3 & 3 & 3 & 2 & 11 & 10 & 10 & 7 & 7 \\
\hline TSF & 7 & 4 & 3 & 4 & 9 & 23 & 11 & 8 & 9 & 17 \\
\hline \multirow[t]{2}{*}{ WRRTF } & --- & 1 & 1 & -- & 1 & 1 & 1 & 1 & 1 & 2 \\
\hline & 189 & 566 & 147 & 598 & 102 & 122 & 135 & 117 & 139 & 188 \\
\hline \multicolumn{11}{|c|}{ Ambient Monitoring $\left(\mu \mathrm{g} / \mathrm{m}^{3}\right)$} \\
\hline & 8.7 & 7.2 & 12.5 & 36 & 15.4 & --- & $\cdots$ & -- & $\overline{--}$ & -- \\
\hline VANB & 3.7 & 5.2 & 4.9 & 9.4 & 4.9 & 0.4 & 0 & 0.8 & 1.8 & 2.7 \\
\hline
\end{tabular}

generators, welding sources, an incinerator and a carpenter shop. Emissions of $\mathrm{NO}_{\mathrm{x}}, \mathrm{SO}_{2}$ and carbon monoxide, are generated primarily from boiler and generator operations. In addition, an acid-etch process also produces some $\mathrm{NO}_{\mathrm{x}}$ emissions that pass through a scrubber and filter system, which removes some of the pollutants before they enter the environment.

During 1994, procedures required one $\mathrm{NO}_{x}$ grab sample per day using a Draeger tube during operation of the acid-etch process. The acid-etch system operated for about 18 days and about 0.0084 tons of nitrogen dioxide was released from acid-etch operations, which is well below the Prevention of Significant Deterioration permitted value of 5.73 tons/y.

\subsection{NONRADIOLOGICAL LIQUID EFFLUENTS}

\section{Summary}

Nonradioactive liquid effluents are disposed of primarily to a waste ditch at the NRF; seepage ponds at the Contained Test Facility, TAN, TRA, ICPP, and WRRTF; an industrial waste pond at ANL-W; and sewage treatment facilities at various locations.

Routine direct disposal of wastes to the Snake River Plain aquifer ceased in 1984. The only other injection wells on the INEL are used for storm water runoff. No waste streams, other than storm water runoff, are discharged directly 
to the Big Lost River, the only surface stream on the INEL that might conceivably accept waste water. As described in Chapter 2, the INEL has initiated a storm-water monitoring program.

Other waste effluents are calculated from the amounts of chemicals used for water treatment, corrosion control, demineralization, cleansers, algicides, and occasionally from waste acids. Sewage processed by treatment facilities is monitored for biochemical oxygen demand, dissolved oxygen, settleable solids, and $\mathrm{pH}$. Results of monitoring sanitary waste streams for these parameters at all INEL facilities are reported quarterly by the INWMIS.

\section{Argonne National Laboratory-West}

During 1994, personnel at ANL-W monitored the Industrial Waste Pond at their facility for $\mathrm{pH}$, cadmium, temperature, total suspended solids, biological oxygen demand, and dissolved oxygen.

\section{Specific Manufacturing Capability Facility}

Most radioactive and hazardous liquid wastes at the Specific Manufacturing Capability facility are recycled or processed through a drum evaporator with the final residue disposed as solid waste. Other hazardous, mixed hazardous, and radioactive wastes are containerized at Satellite Accumulation Areas within the facility, characterized, and transported to appropriate INEL storage facilities for final preparation and disposal to an offsite facility.

Boiler effluent and sanitary wastewater were released to the TAN 750 evaporation pond. A sampling program was established at the Specific Manufacturing Capability facility to collect baseline data for liquid effluent releases beginning in September 1992. As a result of analyses, the facility determined that, beginning in 1994, the number of analytes measured each month could be reduced without risk to the environment. A complete set of analyses would be performed twice per year.

\section{EG\&G/LITCO}

EG\&G Idaho instituted a Nonradiological Liquid Effluent Monitoring Program in fiscal year 1986 to provide environmental monitoring for nonradioactive parameters and pollutants in liquid waste effluents generated within its facilities at the INEL. The program involves sampling, analysis, and data interpretation carried out under a rigorous quality assurance program. A more complete description of the program--effluent stream descriptions, sampling regimes, analytical methods, and presentation and interpretation of the data--were published annually by EG\&G Idaho through 1993 and are now produced by LITCO.

Inorganic monitoring data from one of these waste streams, the liquid effluent to the TRA Cold Waste Pond, are presented in Table 6.5. According to EG\&G/LITCO, metal concentrations were below the applicable regulatory limits for liquid effluent streams at all facilities operated by the contractor in 1994 .

\section{Naval Reactors Facility}

At NRF, the sewage waste stream is monitored for more parameters than appear in the INWMIS reports. Results for 1994 are shown in Table 6.6.

\section{Idaho Chemical Processing Plant}

The extent of effluent monitoring for liquid waste streams varies depending on the nature of the effluents. The largest INEL effluent stream, the service waste at the ICPP, 
is monitored by monthly composite samples analyzed for arsenic, barium, cadmium, chromium, lead, mercury, selenium, silver, chloride, fluoride, nitrate, sulfate, conductivity, total dissolved solids, and $\mathrm{pH}$ (Table 6.7). All analytical results for 1994 were less than concentrations defined as hazardous waste in 40 CFR 261.24.

\begin{tabular}{|c|c|c|c|c|c|}
\hline \multicolumn{6}{|c|}{$\begin{array}{r}\text { TABLE } 6.5 \\
\text { TRA LIQUD EFFLUENT INORGANIC }\end{array}$} \\
\hline \multirow[b]{2}{*}{ Parameter } & \multicolumn{4}{|c|}{ Concentration } & \multirow{2}{*}{$\frac{\text { Toxicity }}{\text { Limit }^{b}}$} \\
\hline & February & May & August & November & \\
\hline Conductivity & 1046 & 573 & 377 & 978 & -- \\
\hline pH & 7.51 & 8.20 & 7.42 & 7.54 & 2 to 12.5 \\
\hline Chemical Oxygen Demand & 59.8 & $<\mathrm{dl}^{\mathrm{c}}$ & 8.4 & $<\mathrm{dl}$ & - \\
\hline Biochemical Oxygen Demand & $<\mathrm{dl}$ & 3.0 & 1.0 & 99 & $\ldots$ \\
\hline Total Organic Carbon & 2.3 & $<\mathrm{dl}$ & 0.7 & 16 & -- \\
\hline Total Dissolved Solids & 804 & 250 & 270 & 710 & - \\
\hline Total Suspended Solids & $<\mathrm{dl}$ & 8.0 & 7.0 & $<\mathrm{dl}$ & ... \\
\hline Chloride Ion & 29.4 & 11.2 & 10.9 & 28.7 & -- \\
\hline Fluoride Ion & 0.40 & 0.14 & 0.15 & 0.42 & -- \\
\hline Nitrate as Nitrogen & 2.10 & 0.98 & 0.89 & 2.40 & -- \\
\hline Total Nitrogen & 0.27 & $<\mathrm{dl}$ & $<\mathrm{dl}$ & $<\mathrm{dl}$ & -- \\
\hline Total Phosphorus & 1.30 & 0.05 & 0.29 & 1.70 & -- \\
\hline $\mathbf{M B A S}^{\mathrm{d}}$ & $<\mathrm{dl}$ & $<\mathrm{dl}$ & $<\mathrm{dl}$ & $<\mathrm{dl}$ & --. \\
\hline Silver & $<\mathrm{dl}$ & $<\mathrm{dl}$ & $<\mathrm{dl}$ & $<\mathrm{dl}$ & 5 \\
\hline Arsenic & 0.17 & $<\mathrm{dl}$ & $<\mathrm{dl}$ & 0.15 & 5 \\
\hline Barium & $<\mathrm{dl}$ & $<\mathrm{dl}$ & $<\mathrm{dl}$ & $<\mathrm{dl}$ & 100 \\
\hline Beryllium & $<\mathrm{dl}$ & $<\mathrm{dl}$ & $<\mathrm{dl}$ & $<\mathrm{dl}$ & - \\
\hline Calcium & 142 & 45.3 & 53.2 & 126 & -- \\
\hline Cadmium & $<\mathrm{dl}$ & $<\mathrm{dl}$ & $<\mathrm{dl}$ & $<\mathrm{dl}$ & 1 \\
\hline Cobalt & $<\mathrm{dl}$ & $<\mathrm{dl}$ & $<\mathrm{dl}$ & $<\mathrm{dl}$ & $\ldots$ \\
\hline Chromium & 0.03 & $<\mathrm{dl}$ & $<$ dl & $<\mathrm{dl}$ & 5 \\
\hline Copper & 0.03 & $<\mathrm{dl}$ & $<\mathrm{dl}$ & $<\mathrm{dl}$ & $\ldots$ \\
\hline Iron & 1.4 & $<\mathrm{dl}$ & $<\mathrm{dl}$ & 0.15 & -.- \\
\hline Mercury & 0.0012 & $<\mathrm{dl}$ & $<\mathrm{dl}$ & $<\mathrm{dl}$ & 0.2 \\
\hline Potassium & 11.5 & $<\mathrm{dl}$ & $<\mathrm{dl}$ & 8.9 & -- \\
\hline Magnesium & 53.9 & 17.1 & 20.3 & 47.7 & $\ldots$ \\
\hline Manganese & 0.03 & $<\mathrm{dl}$ & $<\mathrm{dI}$ & $<\mathrm{dl}$ & -- \\
\hline Sodium & 23.9 & 7.4 & 9.1 & 20.8 & -.. \\
\hline Nickel & $<\mathrm{dl}$ & $<\mathrm{dl}$ & $<\mathrm{dl}$ & $<\mathrm{dl}$ & $\ldots$ \\
\hline Lead & 0.04 & $<\mathrm{dl}$ & $<\mathrm{dl}$ & $<\mathrm{dl}$ & 5 \\
\hline Antimony & $<\mathrm{d} l$ & $<\mathrm{dl}$ & $<\mathrm{dl}$ & $<\mathrm{dl}$ & -. \\
\hline Selenium & $<\mathrm{d} l$ & $<\mathrm{dl}$ & $<\mathrm{dl}$ & $<\mathrm{dl}$ & 1 \\
\hline Thallium & $<\mathrm{dl}$ & $<\mathrm{dl}$ & $<\mathrm{dl}$ & $<\mathrm{dl}$ & -- \\
\hline Zinc & 0.03 & $<\mathrm{dl}$ & $<\mathrm{dl}$ & $<\mathrm{dl}$ & $\ldots$ \\
\hline \multicolumn{6}{|c|}{$\begin{array}{l}\text { Concentrations in mg/L except Specific Conductance }(\mu \mathrm{S}) \text { and } \mathrm{pH} \text { (no units). } \\
\text { EPA maximum concentration of contaminants for the toxicity characteristic from } 40 \text { CFR 261.24. A blank } \\
(--) \text { in this column means that no limit has been established. } \\
\text { Concentration below the detection limit. } \\
\text { d MBAS represents an analysis for surfactants. }\end{array}$} \\
\hline
\end{tabular}




\begin{tabular}{|c|c|c|c|c|}
\hline NRF SEWA & $\begin{array}{r}\text { TA } \\
\text { YON W } \\
\end{array}$ & $\begin{array}{l}6.6 \\
\text { STREAM }\end{array}$ & ALYSES ( & \\
\hline & & oncentratio & & Standard \\
\hline Parameter & Minimum & Maximum & Mean' $^{\mathbf{b}}$ & $\begin{array}{l}\text { or } \\
\text { Guideline }^{c}\end{array}$ \\
\hline Aluminum & $<0.2$ & 0.46 & $<0.25$ & 0.2 \\
\hline Antimony & $<0.3$ & $<0.3$ & $<<0.3$ & $0.3^{*}$ \\
\hline Arsenic & $<0.005$ & 0.0062 & $<0.0052$ & 0.05 \\
\hline Barium & 0.017 & 0.036 & $0.024 \pm 0.006$ & 2.0 \\
\hline Beryllium & $<0.005$ & $<0.005$ & $<<0.005$ & $0.005^{*}$ \\
\hline Cadmium & $<0.01$ & $<0.01$ & $\ll<0.01$ & $0.01^{*}$ \\
\hline Chloride & 88 & 150 & $133 \pm 19$ & 250 \\
\hline Chromium (total) & $<0.02$ & $<0.02$ & $<<0.02$ & 0.1 \\
\hline Copper & 0.012 & 0.04 & $0.018 \pm 0.007$ & 1.3 \\
\hline Cyanide (free) & $<0.005$ & $<0.005$ & $<<0.005$ & 0.2 \\
\hline Iron (total) & 0.2 & 0.5 & $0.33 \pm 0.06$ & $0.3 *$ \\
\hline Lead & $<0.1$ & $<0.1$ & $<<0.1$ & $0.1^{*}$ \\
\hline Manganese & $<0.01$ & 0.03 & $<0.016$ & 0.05 \\
\hline Mercury & $<0.0002$ & $<0.0002$ & $<<0.0002$ & 0.002 \\
\hline Nickel & $<0.04$ & 0.062 & $<0.04$ & 0.1 \\
\hline Nitrogen as Nitrate & $<0.1$ & $<0.1$ & $<<0.1$ & 10 \\
\hline Nitrogen as Nitrite & $<0.04$ & 1.2 & $<0.1$ & 1.0 \\
\hline Nitrogen (total Kjeldahl) & 4 & 20 & $13 \pm 5$ & $\mathrm{~N} / \mathrm{A}$ \\
\hline Oil and Grease & $<5$ & 39 & $<7.8$ & N/A \\
\hline pH & 7.7 & 11.1 & $8.8 \pm 0.5$ & N/A \\
\hline Phosphorus (total) & 2.0 & 5.6 & $3.1 \pm 1.1$ & $\mathrm{~N} / \mathrm{A}$ \\
\hline Selenium & $<0.005$ & $<0.005$ & $\ll<\overline{0} .005$ & 0.05 \\
\hline Silver & $<0.01$ & $<0.01$ & $<<0.01$ & 0.1 \\
\hline Sodium & 148 & 282 & $224 \pm 44$ & N/A \\
\hline Specific Conductance & 990 & 1700 & $1339 \pm 230$ & N/A \\
\hline Sulfate & 50 & 150 & $97 \pm 27$ & 250 \\
\hline Thallium & $<0.01$ & $<0.5$ & $<<0.37$ & $0.5^{*}$ \\
\hline Total Dissolved Solids & 560 & 970 & $794 \pm 121$ & 500 \\
\hline Total Suspended Solids & 36 & 170 & $96 \pm 44$ & N/A \\
\hline Zinc & $<0.05$ & 0.19 & $<0.10$ & 5 \\
\hline 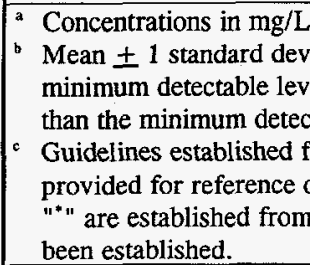 & $\begin{array}{l}\text { and Specific } \\
\text { an values pre } \\
\text { arameter. } M \\
y \text { or secondar } \\
\text { not establish } \\
s \text { method min }\end{array}$ & $\begin{array}{l}\text { tance }(\mu \text { mhos } \\
"<" \text { contair } \\
\text { les preceded } \\
\text { ing water stan } \\
\text { s for the sewa } \\
\text { etectable level }\end{array}$ & $\begin{array}{l}\text { least one value } \\
<" \text { contained } \\
\text { These guidel } \\
\text { meon. Guidelin } \\
\text { means that nc }\end{array}$ & $\begin{array}{l}\text { than the } \\
\text { alues less } \\
\text { are } \\
\text { ollowed by a } \\
\text { ideline has }\end{array}$ \\
\hline
\end{tabular}




\section{Quality Assurance}

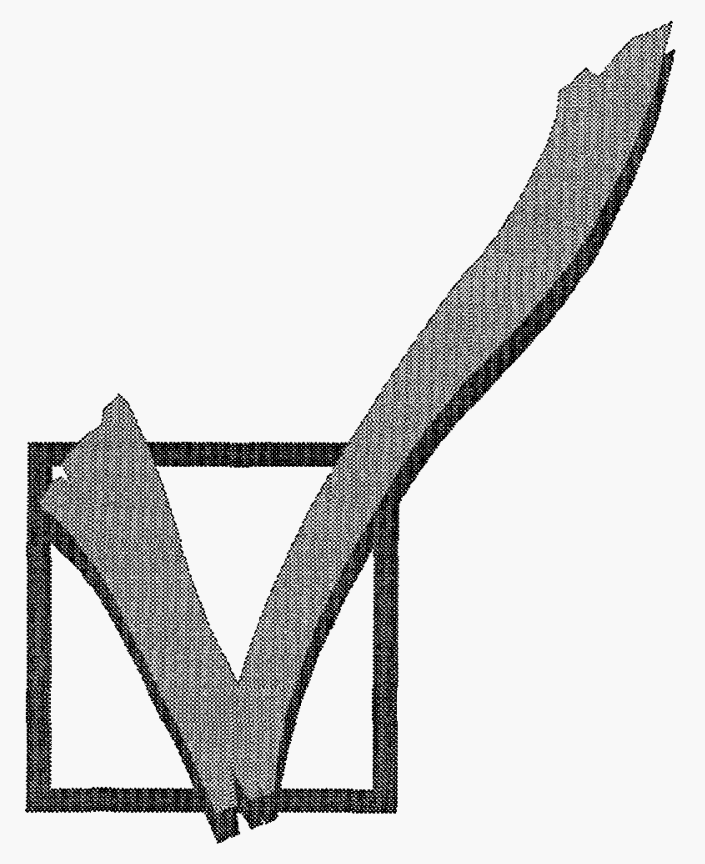





\section{QUALITY ASSURANCE}

\subsection{QUALITY ASSURANCE PROGRAMS}

Quality control and assurance programs were maintained by contractors conducting environmental monitoring and by laboratories performing environmental analyses to ensure consistent and reliable results. Elements of typical quality control programs include the following:

- Adherence to written procedures for sample collection and analytical methods;

- Documentation of program changes;

- Periodic calibration of instruments with standards traceable to the National Institute of Standards and Technology;

- Equipment performance checks;

- Routine yield determinations of radiochemical procedures;

- Replicate samples to determine precision;

- Analysis of blind duplicate and replicate samples;

- Analysis of quality control standards in appropriate matrices to test accuracy;

- Analysis of reagent blanks to verify that there is no radiochemical contamination;

\subsection{LABORATORY INTERCOMPARISON PROGRAMS}

\section{General Information}

Much of the radiological data reported in this document were obtained from the Radiological and Environmental Sciences Laboratory (RESL) of the U.S. Department of Energy. EG\&G/LITCO also used the Radiological Measurements Laboratory (RML) at the Test Reactor Area and the INEL Research Center to perform radiological analyses. These laboratories participate in a variety of programs to ensure the quality of their analytical data.

\section{National Institute of Standards and Technology (NIST)}

The Analytical Measurements Team of the Radiological and Environmental Sciences Laboratory (RESL) has participated each year since 1974 in a Traceability Program with the NIST. Concentrations of several alpha-, beta-, and gamma-emitting radionuclides, generally in liquid media, are determined. These results are reported directly to NIST, who then issues a Report of Test in which the results are compared with the previously undisclosed NIST-certified values. The criterion for traceability is that the results agree to within $5 \%$ of the NIST values. Results for 1994 that had been received included ${ }^{241} \mathrm{Am}$ and tritium. Both analyses were within $2 \%$.

During past years, the RESL Analytical Measurements Team sent samples to other INEL contractors and project office laboratories who voluntarily participated in the INEL Intercomparison Test Program. Results reported by 
all laboratories were compared to RESL values. The RESL Standards and Evaluation Team has assumed responsibility for the continuation of this program.

\section{Quality Assessment Program (QAP)}

The Analytical Measurements Team has also participated each year since 1976 in the Quality Assessment Program (QAP) administered by the DOE Environmental Measurements Laboratory (EML). EML prepares the quality control samples containing various alpha-, beta-, and gamma-emitting nuclides in water, soil, air filter, vegetation, and tissue media and distributes them to numerous DOE contractor laboratories throughout the country. The program is an interlaboratory comparison in that results from the participants are compared with the experimentally determined results of EML. EML issues "QAP" Reports in which the identities of participating laboratories, their results, and comparison to EML results are presented. RESL results for the one distribution that the laboratory participated in during 1994 are compared to the EML results in Table 7.1. Comparisons for the RML and INEL Research Center to EML are shown in Tables 7.2 and 7.3, respectively. EML changed their reporting format and criteria for acceptance of results between the March and September distributions.

\section{Other Programs}

In 1994 RESL continued to participate in the EPA Intercomparison Studies Program for the measurement of radionuclides in drinking water and is currently certified by the State of Idaho for these analyses as required by the National Primary Drinking Water Regulations. RESL may also participate in the International Atomic Energy Agency interlaboratory comparisons on those occasions when the Agency provides sample media of the type and level of radionuclide concentrations normally analyzed in routine procedures.

\section{U.S. Geological Survey}

The USGS submits most ground-water samples requiring radioactive analyses to the Analytical Measurements Team. Samples requiring nonradioactive or organic analyses are submitted to the EPA-certified USGS National Water Quality Laboratory in Arvada, Colorado. The INEL USGS Project Office personnel collect, process, and handle all samples according to guidelines specified in a written quality assurance plan for quality of water activities. Quality assurance samples submitted to RESL and the National Water Quality Laboratory consist of at least $10 \%$ of the total number of samples. Data quality is documented through the use of field logbooks, strict chainof-custody procedures, and a data verification program for analytical results.

USGS Project Office personnel participate in the USGS's National Field Quality Assurance Program which measures the ability of field personnel to accurately measure $\mathrm{pH}$, specific conductance, and alkalinity. Any deficiencies require retesting and, if necessary, corrective action. Technical reviews of the INEL Project Office water-quality program are conducted on two- to three- year intervals by personnel from USGS National Headquarters in Reston, Virginia; Regional Headquarters in Menlo Park, California; and District Headquarters in Boise, Idaho. Written notification of deficiencies are provided to the Project Chief, and corrective actions are required.

\section{INEL Contractors}

Each laboratory on the INEL run by LITCO operates a quality assurance program similar to 
the one described in Section 7.1, including participation in various intercomparison programs. When possible, contractors send samples that cannot be analyzed onsite to commercial laboratories with State of Idaho certification or certification by another state.

\section{Dosimetry}

To verify the quality of the environmental dosimetry program formerly adminstered by
DOE and now conducted by LITCO, the Operational Dosimetry Unit has participated in eight International Environmental Dosimeter Intercomparison Studies. The Operational Dosimetry Unit's results were within $\pm 10 \%$ of the test exposure values on all intercomparisons. Verification of the environmental dosimetry program is through participation in the Measurement Quality Assurance Program every two years.

\begin{tabular}{|c|c|c|c|c|c|c|c|c|c|}
\hline \multicolumn{10}{|c|}{$\begin{array}{l}\text { TABLE } 7.1 \\
\text { DOE ENVIRONMENTAL MEASUREMENTS LABORATORY (EML) QUALITY ASSURANCE PROGRAM } \\
\text { RESULTS COMPARISON FOR RADIOLOGICAL AND ENVIRONMENTAL SCIENCES LABORATORY(RESL) } \\
\text { [1994] }\end{array}$} \\
\hline \multirow{15}{*}{$\begin{array}{l}\text { Sample } \\
\text { Medium } \\
\text { Air }\end{array}$} & \multirow{3}{*}{$\underset{\text { Uniffilter }}{\text { Units }}$} & \multirow[b]{2}{*}{ Radionuclide } & \multirow[b]{2}{*}{ RESL ID\# } & \multicolumn{2}{|c|}{ RESL } & \multicolumn{2}{|c|}{ EML ${ }^{2}$} & \multicolumn{2}{|c|}{ RESL/EML } \\
\hline & & & & Value & Error ${ }^{b}$ & Value & Error & Ratio & $+1=$ \\
\hline & & ${ }^{54} \mathrm{Mn}$ & 1 & 6.7 & 0.6 & 6.69 & $\overline{0.24}$ & $\overline{1.00}$ & $\overline{0.10}$ \\
\hline & & ${ }^{57} \mathrm{Co}$ & 1 & 10.5 & 0.6 & 12.9 & 0.3 & 0.81 & 0.05 \\
\hline & & ${ }^{60} \mathrm{Co}$ & $i$ & 9.7 & 0.7 & 10.2 & 0.3 & 0.95 & 0.07 \\
\hline & & ${ }^{90} \mathrm{Sr}$ & 1 & 1.45 & 0.05 & 1.33 & 0.05 & 1.09 & 0.06 \\
\hline & & ${ }^{106} \mathrm{Ru}$ & 1 & 5.6 & 2.7 & 5.75 & 0.95 & 0.97 & 0.50 \\
\hline & & ${ }^{125} \mathrm{Sb}$ & $i$ & 23.8 & 1.9 & 25.3 & 0.7 & 0.94 & 0.08 \\
\hline & & ${ }^{134} \mathrm{Cs}$ & 1 & 22.2 & 1.1 & 21.1 & 0.3 & 1.05 & 0.05 \\
\hline & & ${ }^{137} \mathrm{Cs}$ & 1 & 9.7 & 0.6 & 10.4 & 0.3 & 1.00 & 0.10 \\
\hline & & ${ }^{144} \mathrm{Ce}$ & 1 & 66.7 & 5.6 & 81.4 & 1.4 & 0.82 & 0.07 \\
\hline & & ${ }^{238} \mathrm{Pu}$ & 1 & 0.069 & 0.030 & 0.072 & 0.004 & 0.96 & 0.42 \\
\hline & & ${ }^{241} \mathrm{Am}$ & $i$ & 0.23 & 0.02 & 0.212 & 0.007 & 1.09 & 0.10 \\
\hline & $\mu \mathrm{g} /$ filter & ${ }^{234} \mathrm{U}$ & 1 & 0.112 & 0.060 & 0.112 & 0.004 & 1.00 & 0.54 \\
\hline & & ${ }^{238} \mathrm{U}$ & 1 & 0.112 & 0.060 & 0.112 & 0.003 & 1.00 & 0.54 \\
\hline \multirow[t]{19}{*}{ Soil } & $\mathrm{Bq} / \mathrm{kg}$ & ${ }^{40} \mathrm{~K}$ & 1 & 470 & 27 & 428 & 35 & 1.10 & 0.11 \\
\hline & & ${ }^{40} \mathrm{~K}$ & 2 & 465 & 38 & 428 & 35 & 1.09 & 0.13 \\
\hline & & ${ }^{90} \mathrm{Sr}$ & 1 & 1.0 & 2.0 & 3.3 & 0.3 & 0.30 & 0.61 \\
\hline & & ${ }^{137} \mathrm{Cs}$ & 1 & 320 & 14 & 280 & 5 & 1.14 & 0.05 \\
\hline & & ${ }^{137} \mathrm{Cs}$ & 2 & 320 & 15 & 280 & 5 & 1.14 & 0.06 \\
\hline & & ${ }^{238} \mathrm{Pu}$ & 1 & 0.17 & 0.05 & 0.31 & 0.18 & 0.55 & 0.36 \\
\hline & & ${ }^{238} \mathrm{Pu}$ & 2 & 0.19 & 0.06 & 0.31 & 0.18 & 0.61 & 0.41 \\
\hline & & ${ }^{230} \mathrm{Pu}$ & 1 & 8.0 & 0.4 & 7.78 & 0.35 & 1.03 & 0.07 \\
\hline & & ${ }^{239} \mathrm{Pu}$ & 2 & 7.6 & 0.4 & 7.78 & 0.35 & 0.98 & 0.07 \\
\hline & & ${ }^{239} \mathrm{Pu}$ & 3 & 7.9 & 0.4 & 7.78 & 0.35 & 1.02 & 0.07 \\
\hline & & ${ }^{241} \mathrm{Am}$ & 1 & 1.74 & 0.14 & 1.73 & 0.05 & 1.01 & 0.09 \\
\hline & & ${ }^{241} \mathrm{Am}$ & 2 & 1.78 & 0.14 & 1.73 & 0.05 & 1.03 & 0.09 \\
\hline & & ${ }^{241} \mathrm{Am}$ & 3 & 1.80 & 0.14 & 1.73 & 0.05 & 1.04 & 0.09 \\
\hline & $\mu \mathrm{g} / \mathrm{g}$ & ${ }^{234} \mathrm{U}$ & 1 & 30.9 & 1.2 & 32.6 & 0.8 & 0.95 & 0.04 \\
\hline & & ${ }^{234} \mathrm{U}$ & 2 & 30.8 & 1.2 & 32.6 & 0.8 & 0.95 & 0.04 \\
\hline & & ${ }^{234} \mathrm{U}$ & 3 & 31.4 & 1.2 & 32.6 & 0.8 & 0.96 & 0.04 \\
\hline & & ${ }^{238} \mathrm{U}$ & 1 & 30.9 & 1.2 & 33.0 & 2.4 & 0.94 & 0.08 \\
\hline & & ${ }^{238} \mathrm{U}$ & 2 & 31.0 & 1.2 & 33.0 & 2.4 & 0.94 & 0.08 \\
\hline & & ${ }^{238} \mathrm{U}$ & 3 & 32.8 & 1.3 & 33.0 & 2.4 & 0.99 & 0.08 \\
\hline
\end{tabular}




\begin{tabular}{|c|c|c|c|c|c|c|c|c|c|}
\hline \multicolumn{10}{|c|}{ TABLE 7.1 (Continued) } \\
\hline \multirow{2}{*}{$\begin{array}{l}\text { Sample } \\
\text { Medium }\end{array}$} & \multirow[b]{2}{*}{ Units } & \multirow[b]{2}{*}{ Radionuclide } & \multirow[b]{2}{*}{ RESL ID\# } & \multicolumn{2}{|c|}{ RESL } & \multicolumn{2}{|c|}{ EML $^{\mathbf{a}}$} & \multicolumn{2}{|c|}{ RESL/EML } \\
\hline & & & & Value & Error & Value & Error & Ratio & $+1=$ \\
\hline \multirow[t]{14}{*}{ Vegetation } & $\mathrm{Bq} / \mathrm{kg}$ & ${ }^{40} \mathrm{~K}$ & 1 & 907 & 37 & 808 & 13 & 1.12 & $\overline{0.05}$ \\
\hline & & ${ }^{40} \mathrm{~K}$ & 2 & 949 & 59 & 808 & 13 & 1.17 & 0.08 \\
\hline & & ${ }^{60} \mathrm{Co}$ & 1 & 11.0 & 1.0 & 10.7 & 0.3 & 1.03 & 0.10 \\
\hline & & ${ }^{60} \mathrm{Co}$ & 2 & 14.0 & 2.0 & 10.7 & 0.3 & 1.31 & 0.19 \\
\hline & & ${ }^{90} \mathrm{Sr}$ & 1 & 536 & 18 & 535 & 121 & 1.00 & 0.23 \\
\hline & & ${ }^{90} \mathrm{Sr}$ & 2 & 529 & 17 & 535 & 121 & 0.99 & 0.23 \\
\hline & & ${ }^{137} \mathrm{Cs}$ & 1 & 168 & 8 & 148 & 3 & 1.14 & 0.06 \\
\hline & & ${ }^{137} \mathrm{Cs}$ & 2 & 174 & 8 & 148 & 3 & 1.18 & 0.06 \\
\hline & & ${ }^{238} \mathrm{Pu}$ & 1 & 0.16 & 0.03 & 0.092 & 0.026 & 1.75 & 0.59 \\
\hline & & ${ }^{238} \mathrm{Pu}$ & 2 & 0.08 & 0.03 & 0.092 & 0.026 & 0.87 & 0.41 \\
\hline & & ${ }^{239} \mathrm{Pu}$ & 1 & 1.39 & 0.10 & 1.25 & 0.15 & 1.11 & 0.16 \\
\hline & & ${ }^{239} \mathrm{Pu}$ & 2 & 1.24 & 0.09 & 1.25 & 0.15 & 0.99 & 0.14 \\
\hline & & ${ }^{241} \mathrm{Am}$ & 1 & 0.87 & 0.07 & 0.816 & 0.074 & 1.07 & 0.13 \\
\hline & & ${ }^{241} \mathrm{Am}$ & 2 & 0.93 & 0.07 & 0.816 & 0.074 & 1.14 & 0.14 \\
\hline \multirow[t]{24}{*}{ Water } & $\mathrm{Bq} / \mathrm{L}$ & ${ }^{3} \mathrm{H}$ & 1 & 110 & 6 & 113 & 7 & 0.97 & 0.05 \\
\hline & & ${ }^{3} \mathrm{H}$ & 2 & 110 & 6 & 113 & 7 & 0.97 & 0.05 \\
\hline & & ${ }^{54} \mathrm{Mn}$ & 1 & 105 & 5 & 108 & 2 & 0.97 & 0.05 \\
\hline & & ${ }^{54} \mathrm{Mn}$ & 2 & 106 & 5 & 108 & 2 & 0.98 & 0.05 \\
\hline & & ${ }^{55} \mathrm{Fe}$ & 1 & 227 & 11 & 187 & 9 & 1.21 & 0.08 \\
\hline & & ${ }^{55} \mathrm{Fe}$ & 2 & 225 & 11 & 187 & 9 & 1.20 & 0.08 \\
\hline & & ${ }^{60} \mathrm{Co}$ & 1 & 363 & 11 & 317 & 6 & 1.15 & 0.04 \\
\hline & & ${ }^{60} \mathrm{Co}$ & 2 & 356 & 11 & 317 & 6 & 1.12 & 0.04 \\
\hline & & ${ }^{134} \mathrm{Cs}$ & 1 & 55 & 2 & 53 & 1 & 1.04 & 0.04 \\
\hline & & ${ }^{134} \mathrm{Cs}$ & 2 & 56 & 2 & 53 & 1 & 1.06 & 0.05 \\
\hline & & ${ }^{137} \mathrm{Cs}$ & 1 & 55 & 3 & 46.6 & 1.1 & 1.18 & 0.07 \\
\hline & & ${ }^{137} \mathrm{Cs}$ & 2 & 54 & 2 & 46.6 & 1.1 & 1.16 & 0.05 \\
\hline & & ${ }^{144} \mathrm{Ce}$ & 1 & 446 & 33 & 491 & 4 & 0.91 & 0.07 \\
\hline & & ${ }^{144} \mathrm{Ce}$ & 2 & 441 & 33 & 491 & 4 & 0.90 & 0.07 \\
\hline & & ${ }^{238} \mathrm{Pu}$ & 1 & 0.94 & 0.05 & 1.06 & 0.10 & 0.89 & 0.09 \\
\hline & & ${ }^{238} \mathrm{Pu}$ & 2 & 0.99 & 0.05 & 1.06 & 0.10 & 0.93 & 0.10 \\
\hline & & ${ }^{239} \mathrm{Pu}$ & 1 & 0.47 & 0.03 & 0.602 & 0.063 & 0.78 & 0.10 \\
\hline & & ${ }^{239} \mathrm{Pu}$ & 2 & 0.49 & 0.03 & 0.602 & 0.063 & 0.81 & 0.10 \\
\hline & & ${ }^{241} \mathrm{Am}$ & 1 & 1.11 & 0.06 & 1.01 & 0.06 & 1.10 & 0.08 \\
\hline & & ${ }^{241} \mathrm{Am}$ & 2 & 1.06 & 0.05 & 1.01 & 0.06 & 1.05 & 0.08 \\
\hline & $\mu \mathrm{g} / \mathrm{mL}$ & ${ }^{234} \mathrm{U}$ & 1 & 1.15 & 0.06 & 1.11 & 0.01 & 1.04 & 0.06 \\
\hline & & ${ }^{234} \mathrm{U}$ & 2 & 1.15 & 0.06 & 1.11 & 0.01 & 1.04 & 0.06 \\
\hline & & ${ }^{238} \mathrm{U}$ & 1 & 1.14 & 0.06 & 1.11 & 0.05 & 1.03 & 0.07 \\
\hline & & ${ }^{238} \mathrm{U}$ & 2 & 1.18 & 0.06 & 1.11 & 0.05 & 1.06 & 0.07 \\
\hline
\end{tabular}


TABLE 7.2

DOE ENVIRONMENTAL MEASUREMENTS LABORATORY (EML) QUALITY ASSURANCE PROGRAM RESULTS COMPARISON FOR RADIOLOGICAL MEASUREMENTS LABORATORY (RML) [1994]

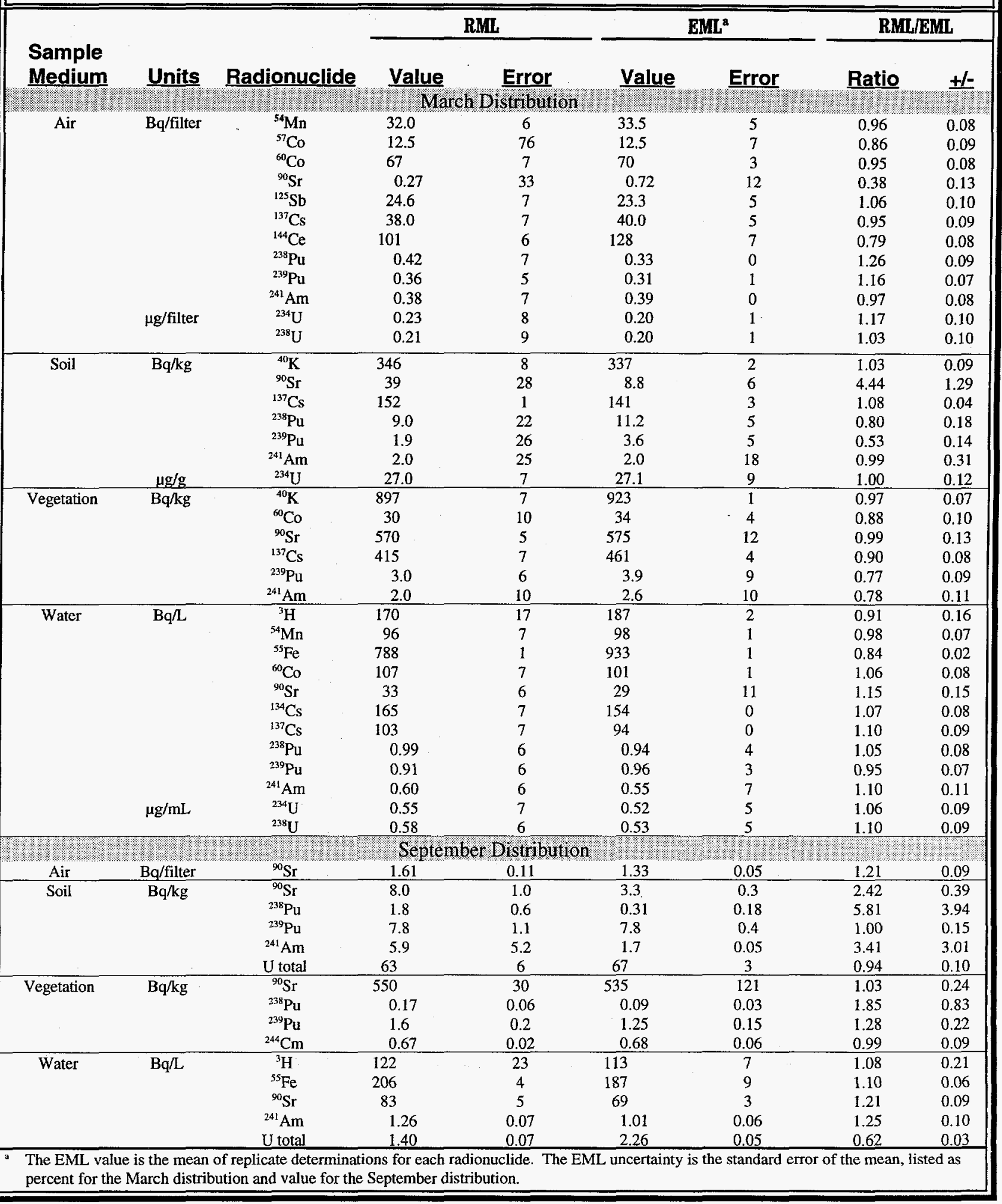


TABLE 7.3

DOE ENVIRONMENTAL MEASUREMENTS LABORATORY (EML) QUALITY ASSURANCE PROGRAM RESULTS COMPARISON FOR INEL RESEARCH CENTER (IRC) [1994]

\begin{tabular}{|c|c|c|c|c|c|c|c|c|}
\hline \multirow{2}{*}{$\begin{array}{l}\text { Sample } \\
\text { Medium }\end{array}$} & \multirow[b]{2}{*}{ Units } & \multirow[b]{2}{*}{ Radionuclide } & \multicolumn{2}{|c|}{ IRC } & \multicolumn{2}{|c|}{ EML $^{a}$} & \multicolumn{2}{|c|}{ IRC/EML } \\
\hline & & & $\frac{\text { Value }}{\text { Ma }}$ & Error & Value & Error & Ratio & $\pm /-$ \\
\hline \multirow[t]{6}{*}{ Air } & $\mathrm{Bq} / \mathrm{filter}$ & ${ }^{54} \mathrm{Mn}$ & 28.9 & 5 & 33.5 & 5 & 0.86 & 0.07 \\
\hline & & ${ }^{57} \mathrm{Co}$ & 9.8 & 6 & 12.5 & 7 & 0.79 & 0.08 \\
\hline & & ${ }^{60} \mathrm{Co}$ & 60.6 & 6 & 70.2 & 3 & 0.86 & 0.06 \\
\hline & & ${ }^{125} \mathrm{Sb}$ & 22.2 & 6 & 23.3 & 5 & 0.95 & 0.08 \\
\hline & & ${ }^{137} \mathrm{Cs}$ & 32.6 & 5 & 40.0 & 5 & 0.81 & 0.06 \\
\hline & & ${ }^{144} \mathrm{Ce}$ & 96 & 17 & 128 & 7 & 0.75 & 0.14 \\
\hline \multirow[t]{5}{*}{ Soil } & $\mathrm{Bq} / \mathrm{kg}$ & ${ }^{40} \mathrm{~K}$ & 403 & 7 & 337 & 2 & 1.20 & 0.10 \\
\hline & & ${ }^{137} \mathrm{Cs}$ & 137 & 4 & 141 & 3 & 0.97 & 0.05 \\
\hline & & ${ }^{238} \mathrm{Pu}$ & 11.1 & 22 & 11.2 & 5 & 0.99 & 0.23 \\
\hline & & ${ }^{239} \mathrm{Pu}$ & 3.4 & 25 & 3.6 & 5 & 0.96 & 0.24 \\
\hline & & ${ }^{241} \mathrm{Am}$ & 1.5 & 29 & 2.0 & 18 & 0.76 & 0.27 \\
\hline \multirow[t]{3}{*}{ Vegetation } & $\mathrm{Bq} / \mathrm{kg}$ & ${ }^{40} \mathrm{~K}$ & 796 & 10 & 923 & 1 & 0.86 & 0.10 \\
\hline & & ${ }^{60} \mathrm{Co}$ & 33.4 & 10 & 34.0 & 4 & 0.98 & 0.11 \\
\hline & & ${ }^{137} \mathrm{Cs}$ & 358 & 3 & 461 & 4 & 0.78 & 0.05 \\
\hline \multirow[t]{7}{*}{ Air } & $\mathrm{Bq} /$ filter & ${ }^{54} \mathrm{Mn}$ & 103 & 3 & 98.2 & 1 & 1.05 & 0.04 \\
\hline & & ${ }^{60} \mathrm{Co}$ & 115 & 3 & 101 & 1 & 1.14 & 0.04 \\
\hline & & ${ }^{134} \mathrm{Cs}$ & 171 & 3 & 154 & 0 & 1.11 & 0.04 \\
\hline & & ${ }^{137} \mathrm{Cs}$ & 105 & 3 & 93.7 & 0 & 1.12 & 0.04 \\
\hline & & ${ }^{238} \mathrm{Pu}$ & 1.01 & 19 & 0.94 & 4 & 1.14 & 0.23 \\
\hline & & ${ }^{239} \mathrm{Pu}$ & 0.97 & 20 & 0.96 & 3 & 1.01 & 0.21 \\
\hline & & ${ }^{241} \mathrm{Am}$ & 0.56 & 25 & 0.55 & 7 & 1.03 & 0.27 \\
\hline \multicolumn{9}{|l|}{40} \\
\hline \multirow[t]{8}{*}{ Air } & $\mathrm{Bq} /$ filter & ${ }^{54} \mathrm{Mn}$ & 5.9 & 0.3 & 6.7 & 0.2 & 0.88 & 0.05 \\
\hline & & ${ }^{57} \mathrm{Co}$ & 10.5 & 0.3 & 12.9 & 0.3 & 0.81 & 0.03 \\
\hline & & ${ }^{60} \mathrm{Co}$ & 9.1 & 0.4 & 10.2 & 0.3 & 0.89 & 0.04 \\
\hline & & ${ }^{106} \mathrm{Ru}$ & 5.1 & 0.8 & 5.8 & 1.0 & 0.88 & 0.20 \\
\hline & & ${ }^{125} \mathrm{Sb}$ & 24.8 & 1.1 & 25.3 & 0.7 & 0.98 & 0.05 \\
\hline & & ${ }^{134} \mathrm{Cs}$ & 20.8 & 0.9 & 21.1 & 0.3 & 0.99 & 0.05 \\
\hline & & ${ }^{137} \mathrm{Cs}$ & 9.2 & 0.4 & 10.4 & 0.3 & 0.88 & 0.04 \\
\hline & & ${ }^{144} \mathrm{Ce}$ & 64 & 5 & 81 & 1.4 & 0.79 & 0.06 \\
\hline \multirow[t]{5}{*}{ Soil } & $\mathrm{Bq} / \mathrm{kg}$ & ${ }^{40} \mathrm{~K}$ & 499 & $4 \overline{2}$ & 428 & 35 & 1.17 & 0.14 \\
\hline & & ${ }^{137} \mathrm{Cs}$ & 302 & 13 & 280 & 5 & 1.08 & 0.05 \\
\hline & & ${ }^{238} \mathrm{Pu}$ & 0.5 & 0.3 & 0.3 & 0.2 & 1.61 & 1.25 \\
\hline & & ${ }^{239} \mathrm{Pu}$ & 7.8 & 2.0 & 7.8 & 0.4 & 1.00 & 0.26 \\
\hline & & ${ }^{241} \mathrm{Am}$ & 2.0 & 0.6 & 1.7 & 0.05 & 1.16 & 0.35 \\
\hline \multirow[t]{3}{*}{ Vegetation } & $\mathrm{Bq} / \mathrm{kg}$ & ${ }^{40} \mathrm{~K}$ & 861 & 62 & 808 & 13 & 1.07 & 0.08 \\
\hline & & ${ }^{60} \mathrm{Co}$ & 11.5 & 0.8 & 10.7 & 0.3 & 1.08 & 0.08 \\
\hline & & ${ }^{137} \mathrm{Cs}$ & 134 & 6 & 148 & 3 & 0.91 & 0.04 \\
\hline \multirow[t]{8}{*}{ Air } & $\mathrm{Bq} /$ filter & ${ }^{54} \mathrm{Mn}$ & 110 & 6 & 108 & 2 & 1.02 & 0.06 \\
\hline & & ${ }^{60} \mathrm{Co}$ & 372 & 19 & 317 & 6 & 1.17 & 0.06 \\
\hline & & ${ }^{134} \mathrm{Cs}$ & 58 & 3 & 53 & 1.2 & 1.09 & 0.06 \\
\hline & & ${ }^{137} \mathrm{Cs}$ & 51 & 2 & 47 & 1.1 & 1.09 & 0.05 \\
\hline & & ${ }^{144} \mathrm{Ce}$ & 465 & 38 & 491 & 4 & 0.95 & 0.08 \\
\hline & & ${ }^{238} \mathrm{Pu}$ & 1.1 & 0.2 & 1.1 & 0.10 & 1.06 & 0.23 \\
\hline & & ${ }^{239} \mathrm{Pu}$ & 0.6 & 0.12 & 0.6 & 0.06 & 0.95 & 0.22 \\
\hline & & ${ }^{241} \mathrm{Am}$ & 1.1 & 0.3 & 1.0 & 0.06 & 1.11 & 0.28 \\
\hline
\end{tabular}




\subsection{DATA PRECISION AND VERIFICATION}

\section{Duplicate Sampling}

As a measure of the quality of data collected, both the Environmental Science and Research Foundation and EG\&G/LITCO used a variety of quality control samples of different media. Quality control samples include duplicate samples (separate samples taken at the same time), split samples (two portions of a sample that are analyzed separately), and spiked samples (samples to which a known amount of a contaminant is added).

Each organization maintained duplicate air samplers at two locations during 1994 (Table 7.4). The Foundation operated these samplers at Atomic City and Rexburg during the last three quarters of the year. The Lockheed samplers were at CFA and TAN during the last two quarters of the year (Table 7.5). Filters from these two samplers were collected and analyzed in the same manner as filters from regular air samplers.

Of the 78 duplicate results obtained by the Foundation, only one (1.3\%) differed at the 2 standard deviation (2s) level, and all were statistically the same at 3 standard deviations (3s). Nine of the 104 comparisons (9\%) for the EG\&G/LITCO were different at $2 s$ and seven of $104(7 \%)$ at the 3 s level.

\section{Independent Data Comparisons}

Another measure of data quality can be made by comparing data collected simultaneously by different organizations. In 1994, there were three organizations, the Foundation, EG\&G/LITCO, and the State of Idaho performing environmental surveillance in conjunction with the INEL. At three sampling locations, the distant location of
Craters of the Moon and on the INEL at EFS and Van Buren Avenue, all three of these organizations currently collect air monitoring data. The Foundation operated EFS and Van Buren samplers from its origination in April 1994 to the end of the year; LITCO set up an air sampler at Craters of the Moon in late June and operated it through the end of the year. Data from these three sampling locations for gross alpha and gross beta are shown in Tables 7.6 and 7.7. The three organizations maintain slightly different collection and analysis schedules. Some of the possible origins of the differences noted between the Foundation's gross alpha/gross beta concentrations and EG\&G/LITCO gross alpha/gross beta concentrations were described in Chapter 4. Table 7.7 also indicates a general trend for gross beta concentrations obtained by the State to be lower than those of both the Foundation and EG\&G/LITCO.

The Foundation also collects quarterly samples of drinking and surface water at five locations in the Magic Valley area jointly with the State Oversight Program. Table 7.8 contains results from analysis of 1994 samples from these locations. All results were statistically the same at the 2 standard deviation level. 


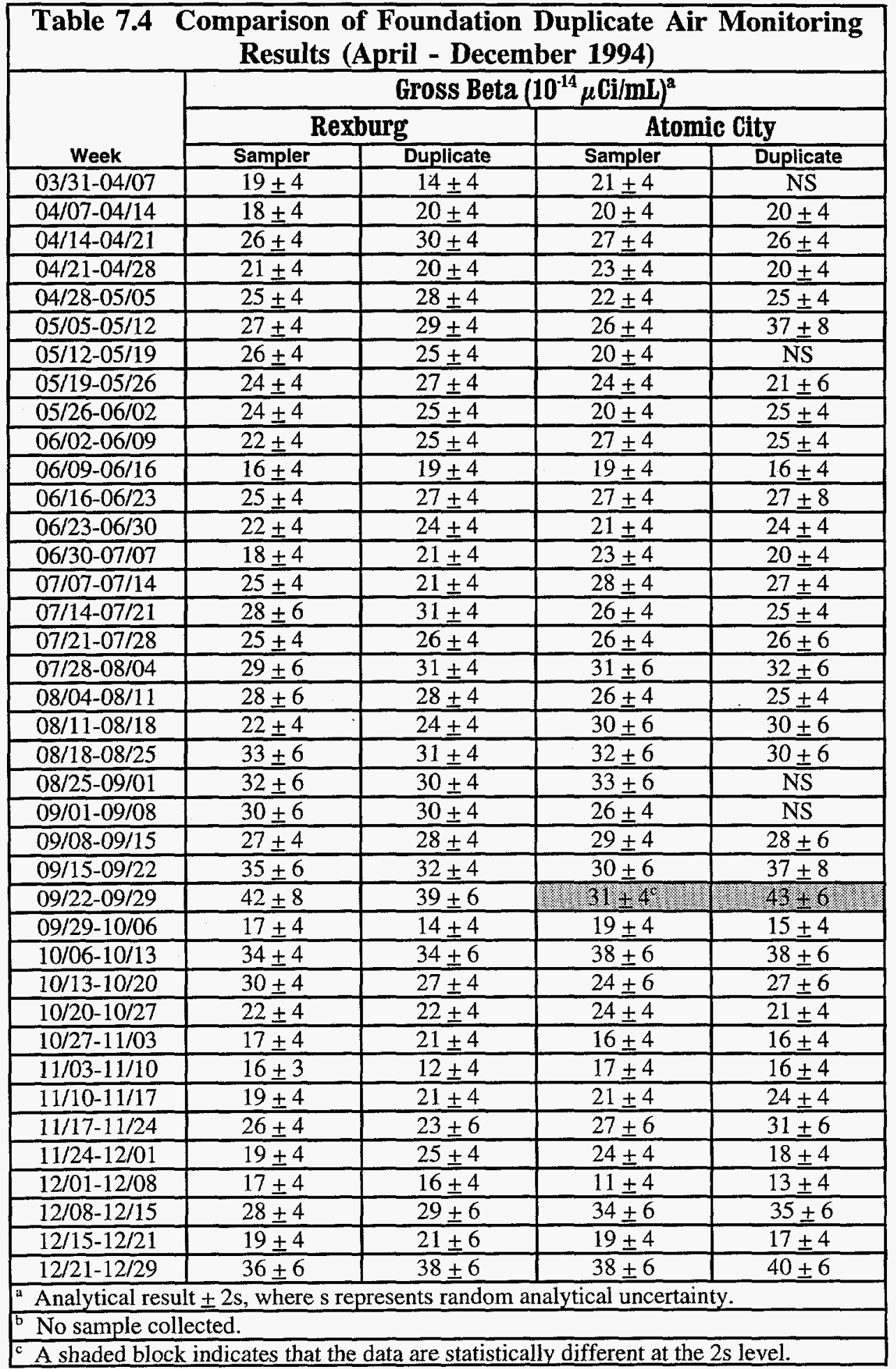




\begin{tabular}{|c|c|c|c|c|c|c|c|c|}
\hline \multirow[b]{4}{*}{ Week } & \multicolumn{8}{|c|}{$\begin{array}{c}\text { Table 7.5 Comparison of EG\&G/LITCO Duplicate } \\
\text { Air Monitoring Results (July - December 1994) }\end{array}$} \\
\hline & \multicolumn{4}{|c|}{ Gross Alpha $\left(10^{-15} \mu \mathrm{Cl} / \mathrm{mL}\right)^{2}$} & \multicolumn{4}{|c|}{ Gross Beta $\left(10^{15} \mu \mathrm{Ci} / \mathrm{mL}\right)^{\mathrm{a}}$} \\
\hline & \multicolumn{2}{|c|}{ CFA } & \multicolumn{2}{|c|}{ TAN } & \multicolumn{2}{|c|}{ CFA } & \multicolumn{2}{|c|}{ TAN } \\
\hline & Sampler & \begin{tabular}{|l} 
Duplicate \\
\end{tabular} & Sampler & Duplicate & Sampler & Duplicate & Sampler & Duplicate \\
\hline $06 / 30-07 / 07$ & $-1.8 \pm 1.6$ & $-1.4 \pm 2.2$ & $-0.6 \pm 1.6$ & $1.3 \pm 3.2$ & $0.7 \pm 3.2$ & $7 \pm 4$ & $18 \pm 4$ & $20 \pm 6$ \\
\hline $07 / 07-07 / 14$ & $9.3+2.8 \%$ & 10.4 .2 .6 & $0.0 \pm 1.6$ & $-1.3 \pm 2.0$ & $2.35 \div 6$ & $24.6=$ & $16 \pm 3$ & $20 \pm 4$ \\
\hline $07 / 14-07 / 21$ & $1.4 \pm 1.8$ & $0.8 \pm 3.2$ & $1.0 \pm 1.8$ & $1.1 \pm 1.6$ & $25 \pm 4$ & $16 \pm 6$ & $21 \pm 4$ & $22 \pm 4$ \\
\hline $07 / 21-07 / 28$ & $2.2 \pm 2.0$ & $0.0 \pm 1.2$ & $0.8 \pm 1.4$ & $1.7 \pm 1.6$ & $25+4$ & $14+4$ & $8 \pm 4$ & $22 \pm 3$ \\
\hline $07 / 28-08 / 04$ & $1.3 \pm 2.4$ & $1.0 \pm 1.6$ & $-0.2 \pm 1.4$ & $1.2 \pm 1.6$ & $22 \pm 4$ & $26 \pm 4$ & $19 \pm 3$ & $19 \pm 3$ \\
\hline $08 / 04-08 / 11$ & $N S^{c}$ & $1.0 \pm 1.4$ & $1.7 \pm 2.0$ & $0.5 \pm 1.6$ & NS & $19 \pm 3$ & $25 \pm 4$ & $21 \pm 4$ \\
\hline $08 / 11-08 / 18$ & $1.9 \pm 2.2$ & $0.9 \pm 1.8$ & $2.1 \pm 2.0$ & $0.3 \pm 1.6$ & $22 \pm 4$ & $20 \pm 3$ & $24 \pm 4$ & $23 \pm 4$ \\
\hline $08 / 18-08 / 25$ & $2.6 \pm 2.4$ & $1.8 \pm 1.8$ & $1.6 \pm 2.0$ & $1.3 \pm 1.4$ & $30 \pm 4$ & $25 \pm 4$ & $29 \pm 4$ & $17 \% 3$ \\
\hline $08 / 25-09 / 01$ & $0.1 \pm 1.8$ & $0.1 \pm 1.4$ & $0.6 \pm 1.8$ & $0.2 \pm 1.6$ & $28 \pm 4$ & $25 \pm 4$ & $25 \pm 4$ & $29 \pm 4$ \\
\hline $09 / 01-($ & $1.0 \pm 1.8$ & $1.3 \pm 1.4$ & $0.0 \pm 1.4$ & $2.3 \pm 1.6$ & $24 \pm 4$ & $19 \pm 3$ & $26 \pm 4$ & $30 \pm 4$ \\
\hline $09 / 08-09 / 15$ & $0.6 \pm 1.8$ & $-0.1 \pm 1.4$ & $1.0 \pm 1.8$ & $2.5 \pm 1.8$ & $25 \pm 4$ & $27 \pm 3$ & $28 \pm 4$ & $23 \pm 3$ \\
\hline $09 / 15-09 / 22$ & $0.6 \pm 2.0$ & $0.2 \pm 1.4$ & $2.0 \pm 1.8$ & $0.4 \pm 1.4$ & $36 \pm 6$ & $25 \geq 4$ & $25 \pm 4$ & $6=3$ \\
\hline $09 / 22-0$ & $2.5 \pm 2.6$ & $0.4 \pm 1.6$ & $1.2 \pm 2.0$ & $0.8 \pm 1.8$ & $24 \pm 4$ & $30 \pm 4$ & $36 \pm 4$ & $33 \pm 4$ \\
\hline $09 / 29$ & $S$ & $1.0 \pm 1.6$ & \pm 1.6 & $-1.2 \pm 1.4$ & NS & $15 \pm 3$ & $16 \pm 3$ & $17 \pm 3$ \\
\hline $10 / 06-10 / 13$ & $0.8 \pm 2.6$ & $1.7 \pm 2.4$ & $-0.2 \pm 2.4$ & $0.7 \pm 2.4$ & $31 \pm 6$ & $42 \pm 6$ & $39 \pm 6$ & $31 \pm 6$ \\
\hline $10 / 13-$ & \pm 8 & $1.6 \pm 2.6$ & $0.0 \pm 1.8$ & $0.8 \pm 1.6$ & $30 \pm 14$ & $22 \pm 4$ & $26 \pm 4$ & $19 \pm 3$ \\
\hline $10 / 20-10 / 27$ & NS & $-1.1 \pm 2.2$ & $1.3 \pm 1.8$ & $0.0 \pm 1.4$ & NS & $15 \pm 4$ & $24 \pm 4$ & $28 \pm 4$ \\
\hline $10 / 27-11 / 03$ & NS & $2.1 \pm 1.8$ & $1.4 \pm 1.8$ & $1.2 \pm 1.8$ & NS & $12 \pm 3$ & $15 \pm 3$ & $16 \pm 3$ \\
\hline $11 / 03-11 / 10$ & $0.0 \pm 1.8$ & $0.2 \pm 1.4$ & $-1.0 \pm 1.4$ & $0.0 \pm 1.4$ & $16 \pm 4$ & $12 \pm 3$ & $16 \pm 3$ & $16 \pm 3$ \\
\hline $11 / 10-11 / 17$ & NS & $-0.4 \pm 1.8$ & $-0.3 \pm 1.6$ & $0.0 \pm 1.6$ & NS & $22 \pm 4$ & $22 \pm 3$ & $20 \pm 3$ \\
\hline $11 / 17-11 / 23$ & $1.1 \pm 3.2$ & $-0.1 \pm 1.6$ & $0.4 \pm 2.0$ & $-0.2 \pm 1.8$ & $36 \pm 6$ & $20 \pm 4$ & $25 \pm 4$ & $26 \pm 4$ \\
\hline $11 / 23-12 / 01$ & $-0.4 \pm 1.8$ & $0.0 \pm 1.4$ & $0.0 \pm 1.4$ & $-0.6 \pm 1.2$ & $29 \pm 4$ & $22 \pm 3$ & $25 \pm 3$ & $24 \pm 3$ \\
\hline $12 / 01-12 / 08$ & $-0.6 \pm 2.0$ & $-1.0 \pm 1.2$ & $0.5 \pm 1.8$ & $-0.7 \pm 1.6$ & $12 \pm 4$ & $13 \pm 4$ & $17 \pm 3$ & $15 \pm 3$ \\
\hline $12 / 08-12 / 15$ & $-1.4 \pm 2.0$ & $0.2 \pm 1.8$ & $-0.4 \pm 1.6$ & $-0.9 \pm 1.6$ & $38 \pm 6$ & $30 \pm 4$ & $29 \pm 4$ & $33 \pm 4$ \\
\hline $12 / 15-12 / 22$ & $-0.9 \pm 2.2$ & $0.0 \pm 1.6$ & $1.7 \pm 1.8$ & $0.9 \pm 1.8$ & $29 \pm 6$ & $20 \pm 4$ & $32 \pm 4$ & $36 \pm 4$ \\
\hline $12 / 22-12 / 29$ & $0.0 \pm 2.6$ & $-0.5 \pm 1.8$ & $-0.6 \pm 1.6$ & $1.0 \pm 1.8$ & $42 \pm 6$ & $34 \pm 4$ & $24 \pm 3$ & 3344 \\
\hline \multicolumn{9}{|c|}{ Analytical result $\pm 2 \mathrm{~s}$, where $s$ represents random analytical uncertainty. } \\
\hline & & & & & he $2 \mathrm{sle}$ & & & \\
\hline
\end{tabular}


7. Quality Assurance

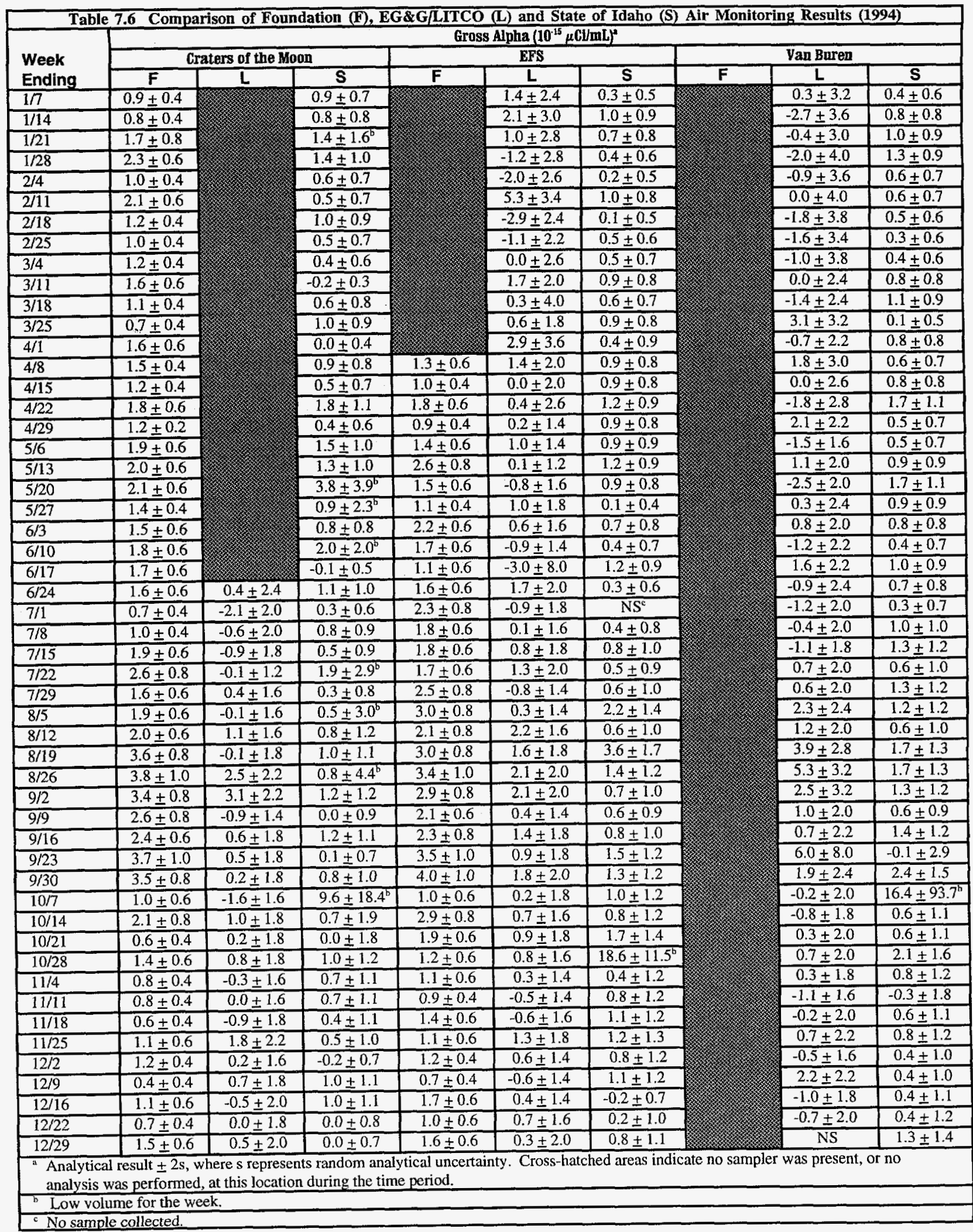




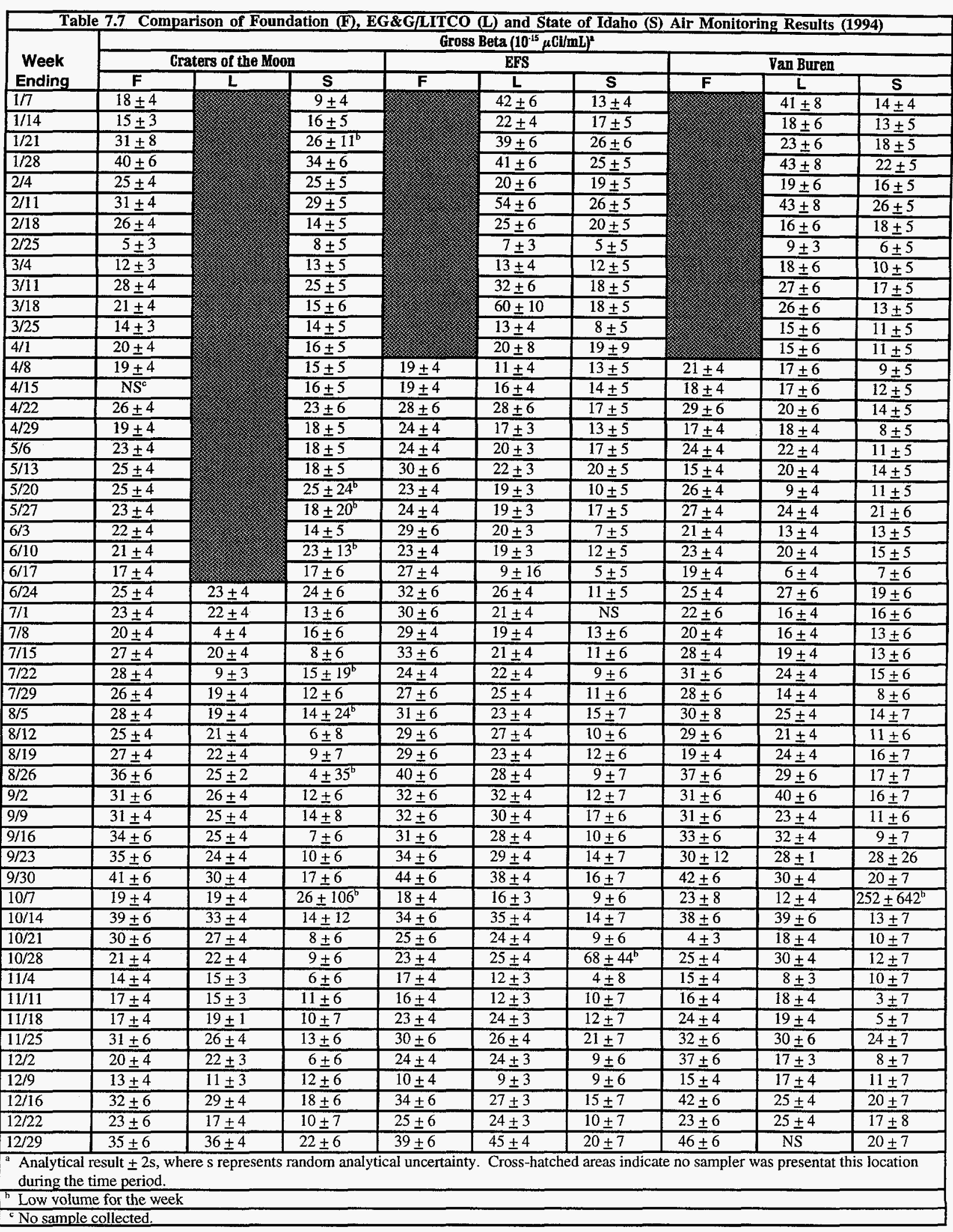




\begin{tabular}{|c|c|c|c|c|c|c|c|}
\hline \multirow[b]{3}{*}{ Location } & \multirow{3}{*}{$\begin{array}{l}\text { omparis } \\
\text { Date }\end{array}$} & \multicolumn{6}{|c|}{$\begin{array}{l}\text { Table } 7.8 \\
\text { ate of Idaho Water Monitoring Results (1994) }\end{array}$} \\
\hline & & \multicolumn{2}{|c|}{$\begin{array}{l}\text { Gross Alpha } \\
\left(10^{-9} \mu \mathrm{Cl} / \mathrm{mL}\right)^{\mathrm{a}}\end{array}$} & \multicolumn{2}{|c|}{$\begin{array}{c}\text { Gross Beta } \\
\left(\mathbf{1 0}^{-9} \mu \mathrm{Cl} / \mathrm{mL}\right)^{\mathrm{a}}\end{array}$} & \multicolumn{2}{|c|}{$\begin{array}{c}\text { Tritium } \\
{\text { (pCi/mL })^{\mathrm{a}}}^{2}\end{array}$} \\
\hline & & Foundation & State & Foundation & State & Foundation & State \\
\hline \multirow{4}{*}{$\begin{array}{c}\text { Minidoka } \\
\text { (Drinking } \\
\text { Water) }\end{array}$} & $02 / 94$ & $-0.3 \pm 1.4$ & $2 \pm 3$ & $-1 \pm 4$ & $0 \pm 2$ & $-0.3 \pm 0.3$ & $0.1 \pm 0.2$ \\
\hline & $05 / 94$ & $1.0 \pm 1.8$ & $1 \pm 3$ & $1 \pm 4$ & $0 \pm 2$ & $-0.1 \pm 0.3$ & $0.0 \pm 0.2$ \\
\hline & $08 / 94$ & $0.0 \pm 1.6$ & $1 \pm 3$ & $-1 \pm 4$ & $2 \pm 2$ & $0.0 \pm 0.3$ & $0.1 \pm 0.2$ \\
\hline & $11 / 94$ & $0.0 \pm 1.6$ & $2 \pm 3$ & $1 \pm 4$ & $1 \pm 2$ & $0.0 \pm 0.3$ & $-0.2 \pm 0.2$ \\
\hline \multirow{4}{*}{$\begin{array}{c}\text { Shoshone } \\
\text { (Drinking } \\
\text { Water) }\end{array}$} & $02 / 94$ & $0.7 \pm 1.6$ & $5 \pm 3$ & $-1 \pm 4$ & $-2 \pm 2$ & $0.1 \pm 0.4$ & $0.0 \pm 0.2$ \\
\hline & $05 / 94$ & $1.4 \pm 1.8$ & $2 \pm 2$ & $2 \pm 4$ & $0 \pm 2$ & $0.0 \pm 0.3$ & $0.0 \pm 0.2$ \\
\hline & $08 / 94$ & $-0.3 \pm 1.4$ & $3 \pm 3$ & $-1 \pm 4$ & $2 \pm 2$ & $0.0 \pm 0.3$ & $0.2 \pm 0.2$ \\
\hline & $11 / 94$ & $0.0 \pm 1.6$ & $1 \pm 3$ & $1 \pm 4$ & $3 \pm 2$ & $0.1 \pm 0.3$ & $-0.1 \pm 0.2$ \\
\hline \multirow{4}{*}{$\begin{array}{c}\text { Bill Jones } \\
\text { Hatchery } \\
\text { (Surface } \\
\text { Water) }\end{array}$} & $02 / 94$ & $0.0 \pm 1.6$ & $2 \pm 2$ & $-1 \pm 5$ & $1 \pm 2$ & $-0.1 \pm 0.3$ & $0.0 \pm 0.2$ \\
\hline & $05 / 94$ & $0.7 \pm 1.6$ & $2 \pm 2$ & $0 \pm 4$ & $1 \pm 2$ & $0.0 \pm 0.3$ & $0.0 \pm 0.2$ \\
\hline & $08 / 94$ & $0.3 \pm 1.6$ & $-1 \pm 2$ & $0 \pm 4$ & $2 \pm 2$ & $0.0 \pm 0.3$ & $-0.2 \pm 0.2$ \\
\hline & $11 / 94$ & $0.7 \pm 1.6$ & $1 \pm 2$ & $2 \pm 4$ & $2 \pm 2$ & $-0.1 \pm 0.3$ & $0.0 \pm 0.2$ \\
\hline \multirow{4}{*}{$\begin{array}{c}\text { Clear } \\
\text { Springs } \\
\text { (Surface } \\
\text { Water) }\end{array}$} & $02 / 94$ & $0.0 \pm 1.6$ & $5 \pm 4$ & $-1 \pm 5$ & $1 \pm 2$ & $0.0 \pm 0.3$ & $0.1 \pm 0.2$ \\
\hline & $05 / 94$ & $2.1 \pm 2.0$ & $2 \pm 3$ & $4 \pm 6$ & $1 \pm 2$ & $-0.2 \pm 0.3$ & $-0.1 \pm 0.2$ \\
\hline & $08 / 94$ & $0.3 \pm 1.6$ & $2 \pm 3$ & $-1 \pm 4$ & $4 \pm 2$ & $0.0 \pm 0.3$ & $-0.2 \pm 0.2$ \\
\hline & $11 / 94$ & $0.7 \pm 1.6$ & $2 \pm 3$ & $2 \pm 4$ & $3 \pm 2$ & $0.1 \pm 0.3$ & $-0.2 \pm 0.2$ \\
\hline \multirow{4}{*}{$\begin{array}{l}\text { Alpheus } \\
\text { Spring } \\
\text { (Surface } \\
\text { Water) }\end{array}$} & $02 / 94$ & $0.3 \pm 1.6$ & $2 \pm 4$ & $2 \pm 4$ & $3 \pm 2$ & $0.2 \pm 0.4$ & $0.1 \pm 0.2$ \\
\hline & $05 / 94$ & $1.0 \pm 1.8$ & $1 \pm 3$ & $3 \pm 6$ & $3 \pm 2$ & $0.1 \pm 0.3$ & $0.0 \pm 0.2$ \\
\hline & $08 / 94$ & $0.3 \pm 1.6$ & $1 \pm 3$ & $0 \pm 4$ & $5 \pm 2$ & $0.0 \pm 0.3$ & $0.2 \pm 0.2$ \\
\hline & $11 / 94$ & $1.7 \pm 1.8$ & $2 \pm 4$ & $1 \pm 4$ & $8 \pm 2$ & $0.0 \pm 0.3$ & $-0.2 \pm 0.2$ \\
\hline
\end{tabular}




\section{APPENDIX A \\ ENVIRONMENTAL STANDARDS AND \\ REGULATIONS}

The following environmental standards and regulations are applicable, in whole or in part, on the INEL Site or at the INEL Site boundary.

U.S. Environmental Protection Agency, "National Primary and Secondary Ambient Air Quality Standards," 40 CFR 50, 1994.

U.S. Environmental Protection Agency, "National Emission Standards for Hazardous Air Pollutants," 40 CFR 61, 1994.

U.S. Environmental Protection Agency, "National Interim Primary Drinking Water Regulations," 40 CFR 141, 1994.

U.S. Environmental Protection Agency, "Hazardous Waste Management System: General," 40 CFR 260, 1994.

U.S. Environmental Protection Agency, "Identifying and Listing of Hazardous Wastes," 40 CFR 261, 1994.

U.S. Environmental Protection Agency, "Standards Applicable to Generators of Hazardous Waste," 40 CFR 262, 1994.

U.S. Environmental Protection Agency, "Standards Applicable to Transporters of Hazardous Waste," 40 CFR 263, 1994.

U.S. Environmental Protection Agency, "Standards for Owners and Operators of Hazardous Waste Treatment, Storage and Disposal Facilities," 40 CFR 264, 1994.
U.S. Environmental Protection Agency, "Interim Status Standards for Owners and Operators of Hazardous Waste Treatment, Storage and Disposal Facilities," 40 CFR 265, 1994.

U.S. Environmental Protection Agency, "Interim Standards for Owners and Operators of New Hazardous Waste Land Disposal Facilities," 40 CFR 267, 1994.

Department of Health and Welfare, State of Idaho, "Rules and Regulations for the Control of Air Pollution in Idaho," 1972, as amended through May 1990.

Department of Health and Welfare, State of Idaho, "Idaho Regulations for Public Drinking Water Systems," 16.01.8000-16.01.8999, October 1993.

The Derived Concentration Guides (DCGs) are based on the DOE standard ${ }^{\mathrm{a}}$ and have been calculated using DOE models and parameters for internal ${ }^{b}$ and external ${ }^{c}$ exposure. These are shown in Table I. The most restrictive guide is listed when there is a difference between the soluble and insoluble chemical forms. The DCGs consider only the inhalation of air, the ingestion of water, or submersion in air. The principal standards and guides for release of radionuclides at the INEL are those of DOE Order 5400.5, entitled "Radiation

\footnotetext{
" U.S. Department of Energy Order 5400.5, "Radiation Protection of the Public and the Environment", January 7, 1993.

b U.S. Department of Energy, Internal Dose Corversion Factors for Calculation of Dose to the Public, DOE/EH-0071, July 1988.

c U.S. Department of Energy, Externa/ Dose Conversion Factors for Calculation of Dose to the Public, DOE/EH-0070, July 1988.
} 
Protection of the Public and the Environment." The DOE standard is shown in Table II along with the EPA standard for protection of the public, airborne pathway only.

Ambient air quality standards are shown in Table III. Water quality standards are dependent on the type of drinking water system sampled. Table IV is a partial list of maximum contaminant levels set by the EPA for public community drinking water systems in $40 \mathrm{CFR}$ 141.

\begin{tabular}{|c|c|c|c|c|c|}
\hline \multicolumn{6}{|c|}{$\begin{array}{l}\text { TABLE I } \\
\text { DERIVED CONCENTRATION GUIDES FOR RADIATON PROTECTION }\end{array}$} \\
\hline \multicolumn{3}{|c|}{$\begin{array}{l}\text { Derived Concentration Guide }{ }^{\mathrm{a}} \\
(\mu \mathrm{C} \mathrm{i} / \mathrm{mL})\end{array}$} & \multicolumn{3}{|c|}{$\begin{array}{l}\text { Derived Concentration Guide }{ }^{\mathrm{a}} \\
(\mu \mathrm{Ci} / \mathrm{mL})\end{array}$} \\
\hline Radionuclide & In Air & In Water & Radionuclide & In Air & In Water \\
\hline Gross Alpha ${ }^{\mathrm{b}}$ & $2 \times 10^{-14}$ & $3 \times 10^{-8}$ & ${ }^{129} \mathrm{I}$ & $7 \times 10^{-11}$ & $5 \times 10^{-7}$ \\
\hline Gross Beta ${ }^{c}$ & $3 \times 10^{-12}$ & $1 \times 10^{-7}$ & ${ }^{131} \mathrm{I}$ & $4 \times 10^{-10}$ & $3 \times 10^{-6}$ \\
\hline${ }^{3} \mathrm{H}$ & $1 \times 10^{-7}$ & $2 \times 10^{-3}$ & ${ }^{132} I$ & $4 \times 10^{-8}$ & $2 \times 10^{-4}$ \\
\hline${ }^{14} \mathrm{C}$ & $5 \times 10^{-7}$ & $7 \times 10^{-5}$ & ${ }^{133} \boldsymbol{I}$ & $2 \times 10^{-9}$ & $1 \times 10^{-5}$ \\
\hline${ }^{24} \mathrm{Na}^{\mathrm{d}}$ & $4 \times 10^{-9}$ & $1 \times 10^{-4}$ & ${ }^{135} \mathrm{I}$ & $1 \times 10^{-8}$ & $7 \times 10^{-5}$ \\
\hline${ }^{41} \mathrm{Ar}$ & $1 \times 10-^{8}$ & - & ${ }^{131 m} \mathrm{Xe}$ & $2 \times 10^{-6}$ & - \\
\hline${ }^{51} \mathrm{Cr}$ & $5 \times 10^{-8}$ & $1 \times 10^{-3}$ & ${ }^{133} \mathrm{Xe}$ & $5 \times 10^{-7}$ & - \\
\hline${ }^{54} \mathrm{Mn}$ & $2 \times 10^{-9}$ & $5 \times 10^{-5}$ & ${ }^{133 \mathrm{~m}} \mathrm{Xe}$ & $6 \times 10^{-7}$ & - \\
\hline${ }^{58} \mathrm{Co}$ & $2 \times 10^{-9}$ & $4 \times 10^{-5}$ & ${ }^{135} \mathrm{Xe}$ & $8 \times 10^{-8}$ & - \\
\hline${ }^{60} \mathrm{Co}$ & $8 \times 10^{-11}$ & $5 \times 10^{-6}$ & ${ }^{135 \mathrm{~m}} \mathrm{Xe}$ & $5 \times 10^{-8}$ & - \\
\hline${ }^{65} \mathrm{Zn}$ & $6 \times 10^{-10}$ & $9 \times 10^{-6}$ & ${ }^{138} \mathrm{Xe}$ & $2 \times 10^{-8}$ & - \\
\hline${ }^{85} \mathrm{Kr}$ & $3 \times 10^{-6}$ & 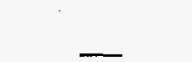 & ${ }^{134} \mathrm{Cs}$ & $2 \times 10^{-10}$ & $2 \times 10^{-6}$ \\
\hline${ }^{85 \mathrm{~m}} \mathrm{Kr}$ & $1 \times 10^{-7}$ & - & ${ }^{137} \mathrm{Cs}$ & $4 \times 10^{-10}$ & $3 \times 10^{-6}$ \\
\hline${ }^{87} \mathrm{Kr}$ & $2 \times 10^{-8}$ & - & ${ }^{138} \mathrm{Cs}$ & $1 \times 10^{-7}$ & $9 \times 10^{-4}$ \\
\hline${ }^{88} \mathrm{Kr}$ & $9 \times 10^{-9}$ & - & ${ }^{139} \mathrm{Ba}$ & $7 \times 10^{-8}$ & $3 \times 10^{-4}$ \\
\hline${ }^{88 d} \mathrm{Rb}$ & $3 \times 10^{-8}$ & $8 \times 10^{-4}$ & ${ }^{140} \mathrm{Ba}$ & $3 \times 10^{-9}$ & $2 \times 10^{-5}$ \\
\hline${ }^{89} \mathrm{Rb}$ & $3 \times 10^{-7}$ & $2 \times 10^{-3}$ & ${ }^{141} \mathrm{Ce}$ & $1 \times 10^{-9}$ & $5 \times 10^{-5}$ \\
\hline${ }^{89} \mathrm{Sr}$ & $3 \times 10^{-10}$ & $2 \times 10^{-5}$ & ${ }^{144} \mathrm{Ce}$ & $3 \times 10^{-11}$ & $7 \times 10^{-6}$ \\
\hline${ }^{90} \mathrm{Sr}$ & $9 \times 10^{-12}$ & $1 \times 10^{-6}$ & ${ }^{238} \mathrm{Pu}$ & $3 \times 10^{-14}$ & $4 \times 10^{-8}$ \\
\hline${ }^{91 \mathrm{~m}} \mathrm{Y}$ & $4 \times 10^{-7}$ & $4 \times 10^{-3}$ & ${ }^{239} \mathrm{Pu}$ & $2 \times 10^{-14}$ & $3 \times 10^{-8}$ \\
\hline${ }^{95} \mathrm{Zr}$ & $6 \times 10^{-10}$ & $4 \times 10^{-5}$ & ${ }^{240} \mathrm{Pu}$ & $2 \times 10^{-14}$ & $3 \times 10^{-8}$ \\
\hline${ }^{99 m} \mathrm{Tc}$ & $4 \times 10^{-7}$ & $2 \times 10^{-3}$ & ${ }^{241} \mathrm{Am}$ & $2 \times 10^{-14}$ & $3 \times 10^{-8}$ \\
\hline${ }^{103} \mathrm{Ru}$ & $2 \times 10^{-9}$ & $5 \times 10^{-5}$ & & & \\
\hline${ }^{106} \mathrm{Ru}$ & $3 \times 10^{-11}$ & $6 \times 10^{-6}$ & & & \\
\hline${ }^{125} \mathrm{Sb}$ & $1 \times 10^{-9}$ & $5 \times 10^{-5}$ & & & \\
\hline $\begin{array}{l}\text { Derived concen } \\
\text { equivalent of } 1 \\
\text { Based on }{ }^{241} \mathrm{Am} \\
\text { Based on the } \mathrm{m} \\
\text { Submersion in }\end{array}$ & $\begin{array}{l}\text { ion guides ( } \\
\text { rem/yr. } \\
\mathrm{Pu} \text {, and }{ }^{240} \mathrm{P} \\
\text { estrictive be } \\
\text { ud of gas is }\end{array}$ & $\begin{array}{l}\text { s) are from } \mathrm{D} \\
\left.\text { hitter }{ }^{228} \mathrm{Ra}\right) \text {. } \\
\text { restrictive th }\end{array}$ & inhalation pathway & sed on an ef & \\
\hline
\end{tabular}




\section{TABLE II \\ RADIATION STANDARDS FOR PROTECTION OF THE PUBLIC IN THE VICINITY OF DOE FACILITIES}

$\frac{\text { Effective Dose Equivalent }}{\text { mrem/yr } \quad \underline{\text { msv/yr }}}$

DOE Standard for routine DOE activities ${ }^{\text {a }}$ (all pathways)

100 1

EPA Standard for site operations

10

0.1 (airborne pathway only)

The effective dose equivalent for any member of the public from all routine DOE operations including remedial activities and release of naturally-occurring radionuclides shall not exceed this value. Routine operations refers to normal, planned operations and does not include accidental or unplanned releases.

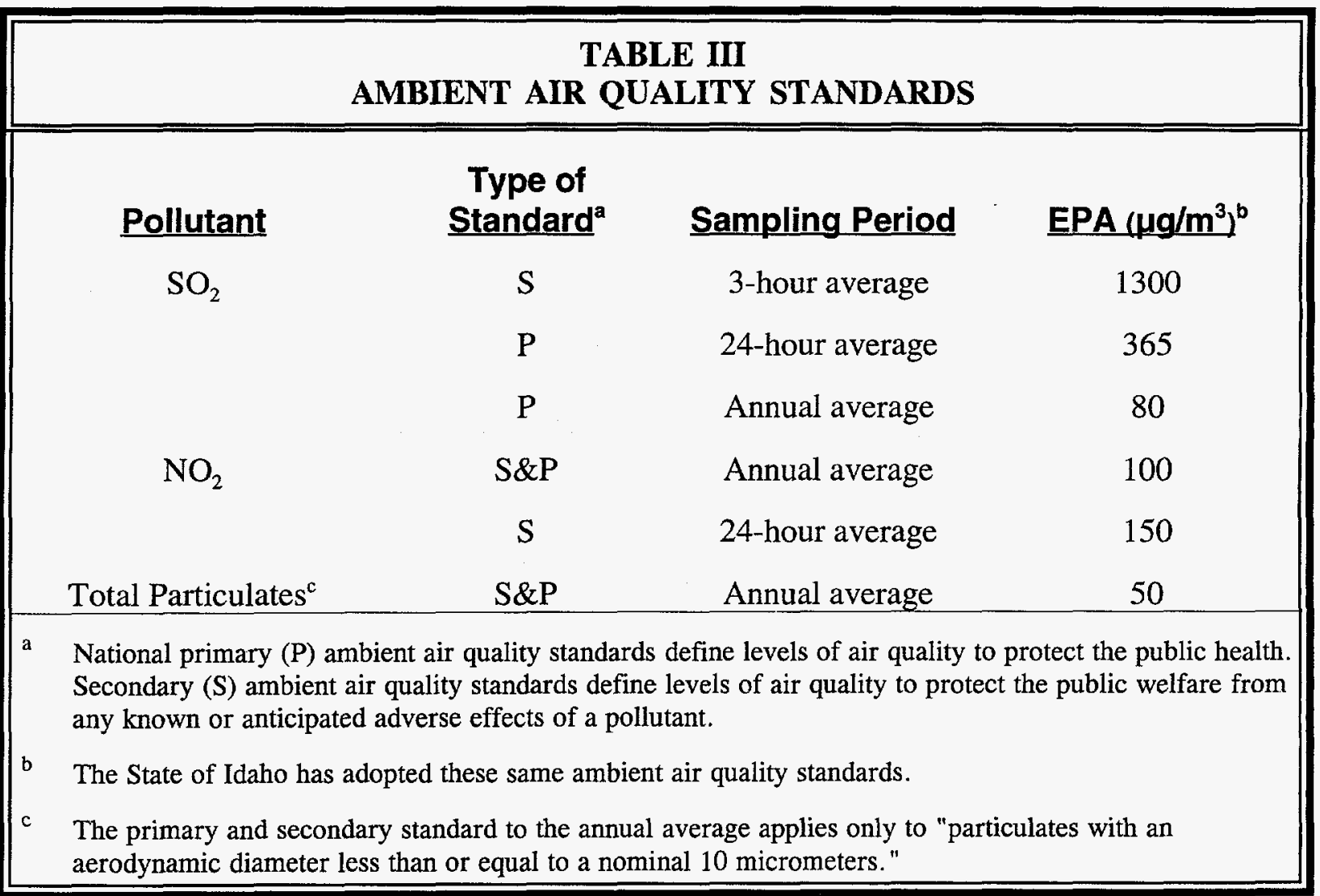




\begin{tabular}{||lc||}
\hline \multicolumn{2}{|c|}{ TABLE IV } \\
\multicolumn{1}{|c|}{ MAXIMUM CONTAMINANT LEVELS FOR NONTRANSIENT } \\
NONCOMMUNITY DRINKING WATER SYSTEMS \\
\hline Gross alpha & $1.5 \times 10^{-8} \mu \mathrm{Ci} / \mathrm{mL}$ \\
Gross beta & $5.0 \times 10^{-8} \mu \mathrm{Ci} / \mathrm{mL}$ \\
Manmade radionuclides & Concentrations resulting in $4 \mathrm{mrem}$ total body \\
& or organ dose equivalent \\
Nitrate (as $\mathrm{N}$ ) & $10.0 \mathrm{mg} / \mathrm{L}$ \\
Fluoride & $4.0 \mathrm{mg} / \mathrm{L}$ \\
Trihalomethanes (Chloroform) & $0.100 \mathrm{mg} / \mathrm{L}$ \\
Carbon Tetrachloride & $0.005 \mathrm{mg} / \mathrm{L}$ \\
Tetrachloroethylene & $0.005 \mathrm{mg} / \mathrm{L}$ \\
Toluene & $1.000 \mathrm{mg} / \mathrm{L}$ \\
1,1,1-trichloroethane & $0.200 \mathrm{mg} / \mathrm{L}$ \\
Trichloroethylene & $0.005 \mathrm{mg} / \mathrm{L}$ \\
Arsenic & $0.05 \mathrm{mg} / \mathrm{L}$ \\
Barium & $2.0 \mathrm{mg} / \mathrm{L}$ \\
Cadmium & $0.005 \mathrm{mg} / \mathrm{L}$ \\
Chromium & $0.10 \mathrm{mg} / \mathrm{L}$ \\
Lead & $0.05 \mathrm{mg} / \mathrm{L}$ \\
Mercury & $0.002 \mathrm{mg} / \mathrm{L}$ \\
Selenium & $0.05 \mathrm{mg} / \mathrm{L}$ \\
Silver & $0.05 \mathrm{mg} / \mathrm{L}$ \\
\hline
\end{tabular}




\section{APPENDIX B STATISTICAL METHODS USED FOR THE ENVIRONMENTAL SURVEILLANCE PROGRAM}

Relatively simple statistical procedures are used to analyze the data from the INEL environmental surveillance program. Environmental Surveillance Program personnel initially review field collection information and analytical results to determine whether there are identifiable errors that would invalidate or limit the use of the results. Examples of these might be power outages at air sampler locations, torn membrane filters, or evidence of laboratory cross-contamination. Data that pass this initial screening are then evaluated for statistical significance with respect to laboratory analytical uncertainties, sample locations, reported releases from INEL operations, meteorological data, and worldwide events that might conceivably have an effect on the INEL environment.

For radiological data, individual analytical results are presented in this report with plus or minus ( \pm ) two analytical standard deviations $(2 \mathrm{~s})$, where all analytical uncertainties have been estimated, and "s" is an estimate of the population standard deviation " $\sigma . "$ Many of the results were less than or equal to $2 \mathrm{~s}$ (and, in fact, some were negative), which means that they were below the minimum detectable concentration. For example, in gamma spectrometric analyses, a given radionuclide is not considered detected unless the net count in the peak is greater than three times its estimated analytical uncertainty (3s). If the result lies in the range of two to three times its estimated analytical uncertainty ( $2 \mathrm{~s}$ to $3 \mathrm{~s}$ ), and assuming that the result belongs to a Gaussian distribution, detection of the material by the analysis may be questionable because of statistical variations within the group of samples. If the result exceeds $3 \mathrm{~s}$, there is confidence that the material was detected (or, that the radionuclide was present in the sample).

A deliberate search for specific nuclides can be made and results reported, but such results might include negative values or small positive values where the result is less than or equal to $2 \mathrm{~s}$. Analyses with results in the questionable range $(2 \mathrm{~s}$ to $3 \mathrm{~s})$ are published in this report with the understanding that there is some doubt as to whether the material was actually present.

There are many factors that can influence the result to some degree, and these factors are considered and included in the methods used to determine the estimated uncertainty of the measurement. Uncertainties in measurements near the minimum detectable concentration are primarily caused by counting statistics. For low concentrations near the minimum detectable concentration, the uncertainty in the measurement is nearly equal to the measurement itself, and the lower limit of the range of the measurement approaches "zero." Such a result might not be very reliable because the uncertainty is only an estimate and the actual probability distribution of the results is not usually known. In reality, the material being measured may not actually be present in the sample. Therefore, when analytical results show a measurement very near the minimum detectable concentration, statistical tools, meteorological data, and Site release information are all considered when interpreting and evaluating the results.

Arithmetic means were calculated using actual assay results, regardless of their being 
above or below the minimum detectable concentration. The uncertainty of the mean, or the $95 \%$ confidence interval, was determined by multiplying the standard deviation of the mean (also called the standard error of the mean) or $s /(n)^{1 / 2}$ by the $t_{(0.05)}$ statistic. Means for which the $95 \%$ confidence interval does not include zero were assumed to indicate detectable amounts of activity. In situations where the analytical results of a group of samples are near the minimum detectable concentration, the $95 \%$ confidence interval for the mean may not include zero and thus appears to be statistically significant even though, on the basis of the $2 \mathrm{~s}-\mathrm{to}-3 \mathrm{~s}$ criterion, it is doubtful that any individual sample contained detectable radioactivity.

Geometric means were calculated by summing the natural logarithms (ln) of the positive analytical results, dividing by the number of samples (n), and then transforming the quotient. If the result was either a negative number or a zero, the $\ln$ of the smallest positive, nonzero measurement in the group was used. The $95 \%$ confidence interval was determined by multiplying the standard deviation of the geometric mean by the $t_{(0.05)}$ statistic and then transforming the result. The actual interval is determined by dividing the transformed mean by the transformed $95 \%$ confidence interval term for the lower limit, then multiplying the mean by the confidence interval term for the upper limit.

Unpaired t-tests were used to determine whether the annual means for the INEL or boundary stations were greater than the annual means for the distant stations. All statistical tests used a level of significance of 5\% $(\alpha=0.05)$. 


\section{DISTRIBUTION RECORD FOR DOE/ID-12082(94)}

\section{Internal Distribution}

DOE-ID

G. L. Beausoleil, AFM/RWMC

M. J. Bonkoski, PM/SNF

G. C. Bowman, AM/OID

T. F. Burns, AM/OPE

R. L. Carlile, FM/TAN

R. D. Carlson, D/RESL

J. T. Case, PM/WM

L. L. Fritz, PM/IFF

L. A. Green, PM/ER

J. W. Hobbs, PM/SP

W. D. Jensen, FM/ICPP

R. A. King, M/OC

J. L. Lyle, DAM/OPE

C. R. Nichols, SS/Mgr

W. N. Sato, AAM/OPA\&RM

R. J. Secondo, PM/MG

R. A. Taft, FM/CFA\&WROC

R. R. Throckmorton, CC/OCC

J. M. Wilcynski, M/DOE-ID

A. C. Williams, PM/IM

C. J. Webb, ADM/DOE-ID

E. J. Ziemianski, FM/TRA

\section{Argonne-West}

J. I. Sackett, Manager

G. C. Marshall, M/ESWM

\section{Argonne Area Office/CHO}

E. J. Hughes, Manager

\section{NOAA-ARLFRD}

G. E. Start, Acting Director

INEL Tech Library (5)

ES\&R Foundation (400)

Total Copies Printed (600)
Lockheed Idaho Technologies Co.

W. J. Denson, President

W. A. Haller, VP/ES\&H

C. L. Tellez, DD/RA

M. S. Litus, DM/EP

J. R. Mitchell,DM/NEPA

B. D. Andersen, EM

D. J. Blumberg, EC

J. A. Durrant, OSHA

L. V. Street, EM

D. J. Wiggins, NEPA

R. N. Wilhelmsen, EM

D. J. Claflin, TP (8)

P. N. Creighton, M/OMB

W. E. Harrison, M/EE\&LS

R. D. Johnson, $M / S \& E$

$\mathrm{K}$. Langley, M/PRP, RCO

J. L. McAnally, DM/ERWM

R. S. Watkins, AM/ES\&Q

Westinghouse Electric Corporation

J. G. Podgursky, M/RC (2)

J. L. Lucas, NRF Manager

\section{PNRO-IBO}

T. M. Bradley, M/Operations

R.D.E. Newbry, Env. Proj. Off. (2)

U.S. Geological Survey

L. J. Mann, Project Chief 


\section{DISTRIBUTION LIST FOR DOE/ID-12082(94)}

\section{External Distribution}

Richard Aiken, Environmental Audit, DOE-HQ, Washington, DC

W. Bruce Arnell, District Seven Health Department, Idaho Falls, ID

Robert W. Barber, Compliance Programs, DO-HQ, Washington, DC

Robert Bernero, Nuclear Materials Safety and Safeguards, NRC, Washington, DC

Carol M. Borgstrom, NEPA Project Assistance, DOE, Washington, DC (2)

Charles W. Borup, DOE, SR, Aiken, SC

Dave Brekke, Sandia National Laboratory, Livermore, CA

Richard Brey, Idaho State University, Pocatello, ID

Barry Burnell, Southeastern District Health Department, Blackfoot, ID

Michael Butler, Environmental Programs and Projects, DOE, BH, Upton, NY

Robert Bryce, Pacific Northwest

Laboratory, Richland, WA

Linford J. Campbell, Idaho Department of Water Resources, Boise, ID

William R. Carlton, Savannah River Technology Center, Aiken, SC

Carrie M. Carter, DOE-OAK, Oakland, CA

Honorable Helen Chenoweth, U. S. House of Representatives, Washington, DC
Audrey Cole, Division of Environmental Quality, IDHW, Pocatello, ID

Wally Cory, Division of Environmental Quality, IDHW, Boise, ID

J. Donald Cossairt, Fermi Laboratory, Batavia, IL

Honorable Larry E. Craig, U.S. Senate, Washington, DC

Honorable Mike Crapo, U. S. House of Representatives, Washington, DC

James T. Davis, Environment, Safety \& Quality Assurance Division, DOE-OAK, Oakland, CA

Weldon Dillow, Environmental Protection Division, DOE-OR, Oak Ridge, TN

Roger L. Dirkes, Manager, Surface Environmental and Surveillance Project, PNL, Richland, WA

James Donnelly, DOE-OR, Oak Ridge, TN

Daniel A. Dreyfus, Nuclear Energy, DOEHQ, Washington, DC

Don Elle, DOE-NV, Las Vegas, NV

Fred D. Ferate, II, Environmental Science Department, NTS, Mercury, NV

Robert Ferguson, INEL Oversight Office, IDHW, Idaho Falls, ID

Michael J. Flannigan, Director of EHD, DOE-CH 
Thomas F. Gesell, Radiation Safety, Idaho State University, Pocatello, ID

Norbert Golchert, Occupational Health \& Safety Department, ANL, Argonne, IL

Orville Green, IDHW, Boise, ID

Andrea Gralak, Center for Environmental Information Management, Washington, D.C.

Thomas P. Grumbly, Office of Environmental Restoration and Waste Management, HQ, Washington, DC

William Gunter, Criteria and Standards Division, EPA, Washington, DC (2)

Joy Haftel, Congressional Information Service, Bethesda, MD

John B. Hall, Quality, Safety \& Health Programs, DOE-RL, Richland, WA

William L. Harrell, Environmental Protection Division DOE, AL, Albuquerque, NM

Brett Hayball, Environmental Coordinator, Shoshone-Bannock Tribe, Ft. Hall, ID

James D. Heffner, Savannah River Site, Aiken, SC

Eva Hickey, PNL, Richland, WA

Gerald V. Hurst, Public Health District

Five, Twin Falls, ID

Hue-Su Hwang, Sandia National

Laboratory, Albuquerque, NM

William Isherwood, LLNL, Livermore, CA

Paul Jehn, Idaho Department of Health and Welfare, Boise, ID
Matthew Johansen, DOE-LAAO, Los Alamos, NM

Jim Johnston, INEL Oversight Office, IDHW, Idaho Falls, ID

Joseph Juetten, DOE-OAK, Oakland, CA

Honorable Dirk Kempthorne, U. S. Senate, Washington, D.C.

Michael A. Kilpatrick, Environmental Audit, DOE-HQ, Washington, DC

Michael H. Kleinrock, Environmental Compliance, DOE-HQ, Washington, DC

Patricia Kraps, FERMCO, Cincinnati, $\mathrm{OH}$

Philip Krey, Environmental Measurements Laboratory, DOE-CH, New York, NY

Andrew C. Lawrence, Environmental Compliance, DOE-HQ, Washington, DC

Jerry Leitch, Radiation Division, EPA, Seattle, WA

Larry J. Madl, WIPP, Carlsbad, NM

Helen McCammon, Ecological Research, OHER, DOE-HQ, Washington, DC

Daniel A. McGrath, Pantex, Amarillo, TX

Robert P. Miltenberger, Brookhaven National Laboratory, Upton, NY

Leland Mink, University of Idaho, Moscow, ID

Anita Mullen, Environmental Monitoring \& Support Laboratory, EPA, Las Vegas, NV

John B. Murphy, ORNL, Oak Ridge, TN 
Ross Natoli, Environmental Compliance

Division, DOE-HQ, Washington, DC

Vicki Snitzler-Neek, Craters of the Moon National Monument, Arco, ID

Richard W. Oldham, Environmental Monitoring Support Services, WVNS, West Valley, NY

Steve Oberg, INEL Oversight Program, IDHW, Boise, ID

William S. Osburn, Jr., Ecological Research Division, OHER, DOE, Washington, DC

Jack Palmer, Division of Environmental Quality, IDHW, Pocatello, ID

Raymond Pelletier, Environmental Guidance, DOE, Washington, DC

James A. Phoenix, Technical Programs Branch, DOE, Los Alamos, NM

Esteban Picazo, West Valley Nuclear Services, West Valley, NY

Allen Reed, Reed's Dairy, Idaho Falls, ID

Leslie L. Reed, WIPP, Carlsbad, NM

Lotwick Reese, Idaho Department of Water Resources, Boise, ID

Gene Runkle, HPD, DOE-AL, Albuquerque, NM

Robie Russell, Region 10, EPA, Seattle, WA

L. E. Scarburgh, EPA Idaho Operations

Office, Boise, ID

Randal Scott, Compliance and Program

Coordination, DOE-HQ, Washington, DC
George Setlock, Health, Safety and Environ-ment, Rocky Flats Plant, Golden, $\mathrm{CO}$

Rajendra K. Sharma, Fuel Cycle \& Test Programs, DOE, HQ, Washington, DC

George Sherwood, DOE-HQ, Germantown, MD

Michael Silverman, EPA Idaho Operations Office, Boise, ID

John M. Sims, LLNL, Livermore, CA

C. L. Soden Environmental Protection

Division, DOE-AL, Albuquerque, NM

Lee S. Sygitowicz, REECO, Las Vegas, NV

A. L. Taboas, DOE, CH, AAO-East, Argonne, IL

Rudy T. Taylor, Environmental Protection Dept, Pantex, Amarillo, TX

J. G. Themelis, Environment and Health Division, DOE, AL, Albuquerque, NM

Lynne Kukler Wade, Idaho, Nevada and San Francisco Operations Division, DOEHQ, Washington, DC

Dana Ward, DOE-RL, Richland, WA

John Welhan, Department of Geology, ISU, Pocatello, ID

Spence Wood, Department of Geology and Geophysics, BSU, Boise, ID

Norman Young, Idaho Department of Water Resources, Boise, ID 
County Commissioners:

Bannock County, Pocatello, ID

Bingham County, Blackfoot, ID

Bonneville County, Idaho Falls, ID

Butte County, Arco, ID

Clark County, Dubois, ID

Jefferson County, Rigby, ID

Lemhi County, Salmon, ID

Madison County, Rexburg, ID

Public Reading Rooms and INEL ER\&WM repositories

INEL Site Specific Advisory Board 